\title{
EGYDIMENZIÓS FÉM NANOSZERKEZETEK ELŐÁLLÍTÁSA ÉS VIZSGÁLATA
}

\author{
$\mathrm{Ph}$. D. értekezés
}

\section{MOHL MELINDA}

Szegedi Tudományegyetem

Alkalmazott és Környezeti Kémiai Tanszék

Szeged

2011 
Témavezető:

Dr. Kónya Zoltán 


\section{Tartalomjegyzék}

1. BEVEZETÉS .

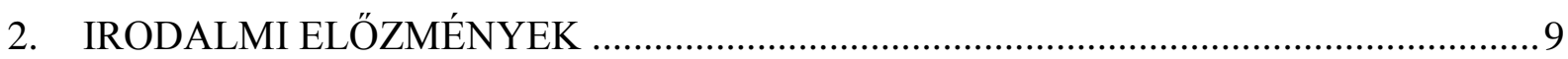

2.1. Egydimenziós nanoszerkezetek ………….....................................................

2.1.1. Egydimenziós nanoszerkezetek jellemző tulajdonságai és alkalmazásai.............9

2.1.1.1. Hőmérsékleti stabilitás .......................................................................

2.1.1.2. Elektrontranszport tulajdonságok ......................................................... 10

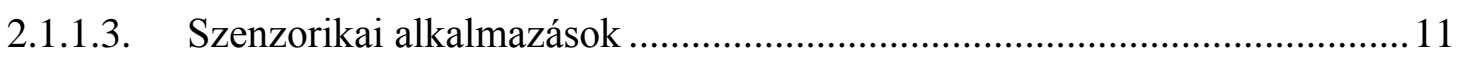

2.1.2. Egydimenziós nanoszerkezetek elóállitási módszerei ........................................... 11

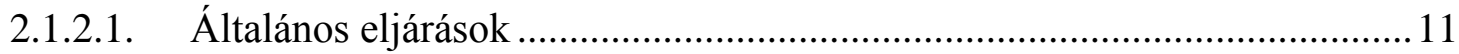

2.1.2.2. Anizotrop kristályszerkezettel rendelkező anyagok...................................... 17

2.1.2.3. Templátok által elősegített elöállítás............................................................ 18

2.1.2.4. Elöre szintetizált nanoszerkezetek, mint templátok ……………………......22

2.1.3. Fém nanokristályok alakját befolyásoló ionok, védőmolekulák ..........................23

2.2. Egydimenziós réz nanoszerkezetek elő́lllítási módszerei ........................................29

2.2.1. Templátok segítségével történő elóállítás ………………………………….....29

2.2.1.1. Elektrokémiai leválasztás pórusos templátokba..........................................29

2.2.1.2. Micellák, mint szerkezetirányító struktúrák .................................................. 30

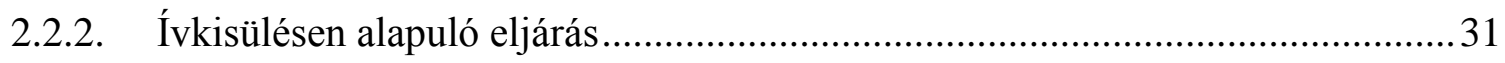

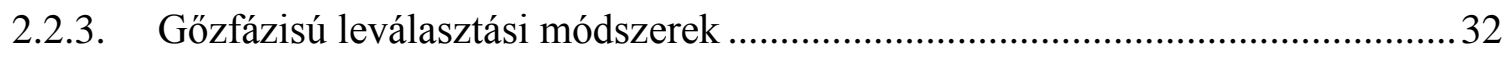

2.2.3.1. Kémiai gőzleválasztás (Chemical Vapour Deposition - CVD) ................... 32

2.2.3.2. Vákuum gőzleválasztás (Vacuum Vapour Deposition - VVD).....................32

2.2.3.3. Gőz-Szilárd fázisú reakció (Vapour-Solid Reaction Growth - VSRG).......33

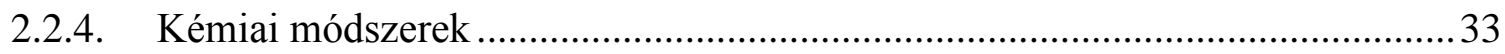

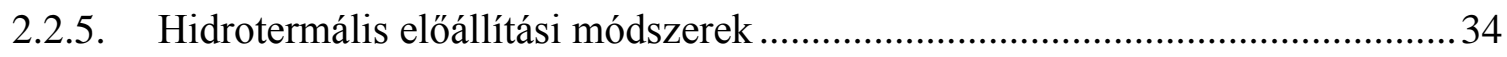

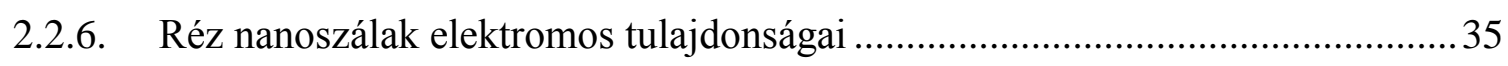

2.3. Galvanikus fémcsere helyettesítési reakció ……………........................................... 37

2.3.1. Nemesfém nanoszerkezetek előállitása fémcsere helyettesítési reakcióval ........37

2.3.2. Fémcsere helyettesítéssel előállított nanoszálak a katalízisben............................40

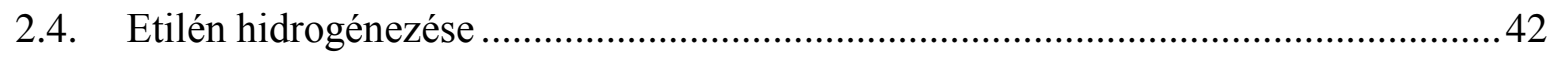

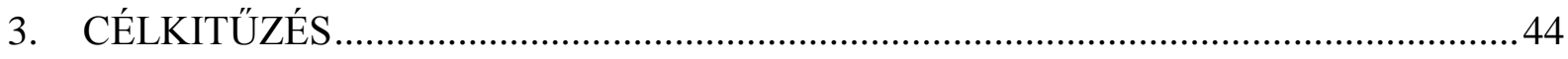

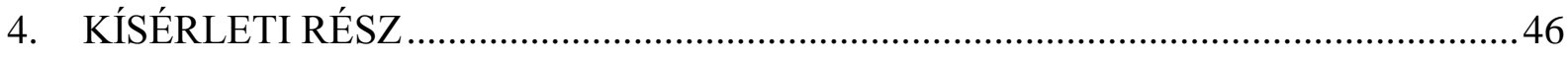

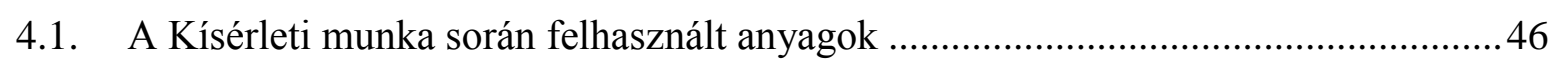

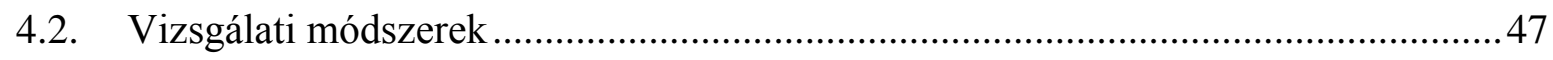

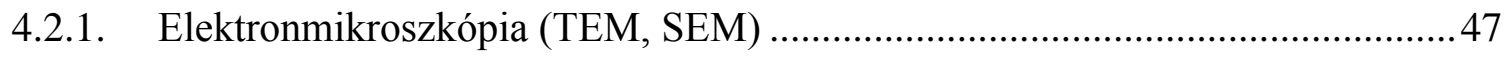

4.2.2. Röntgen diffraktometria (XRD) .................................................................. 48

4.2.3. Röntgen fotoelektron spektroszkópia (XPS) ……………………................... 48 


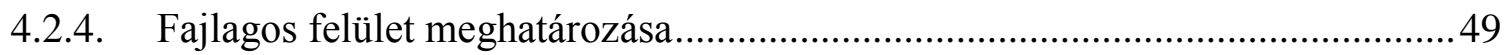

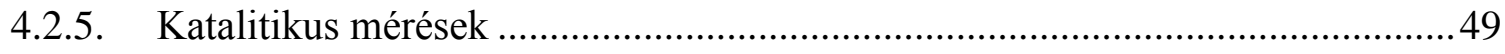

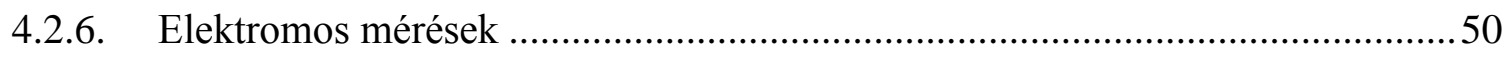

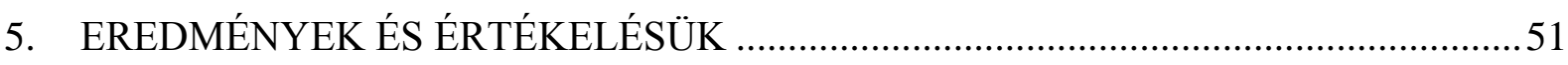

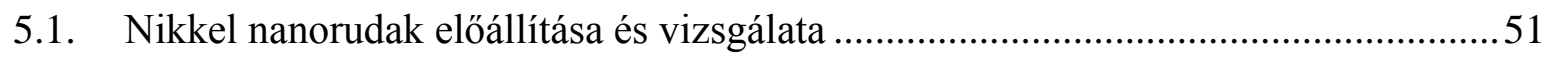

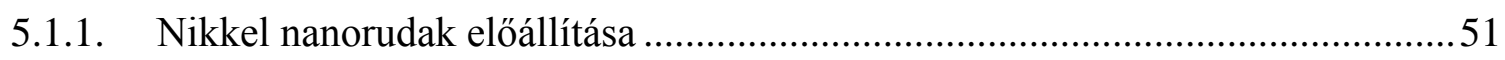

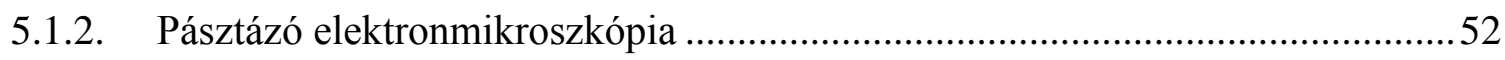

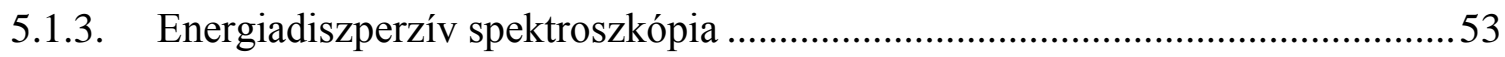

5.2. Pórusos nemesfém nanorudak előállítása, vizsgálata és etilén hidrogénezésben

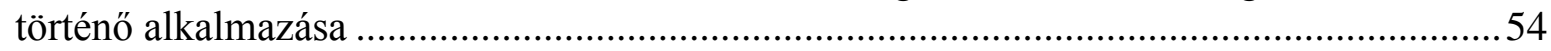

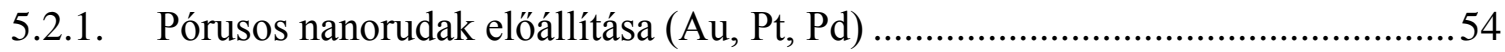

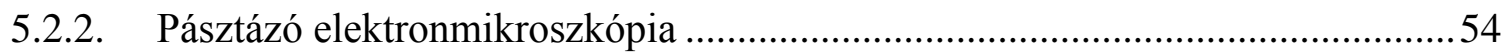

5.2.3. Energiadiszperzív spektroszkópia és röntgen diffraktometria............................56

5.2.4. Röntgen fotoelektron spektroszkópia (XPS) ….............................................57

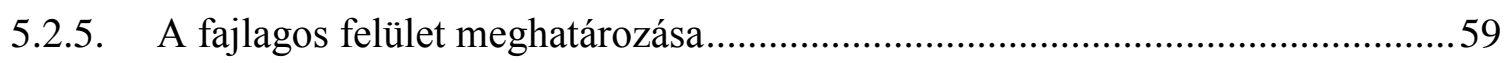

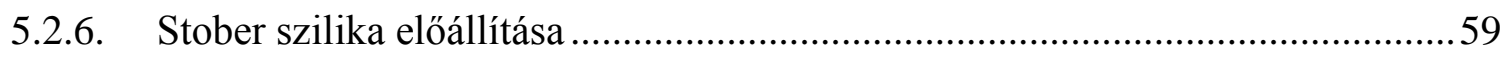

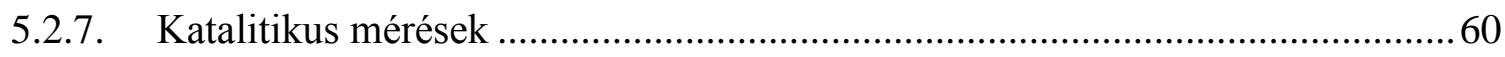

5.2.8. Etilén hidrogénezés membránba ágyazott palládium nanorészecskéken ...........63

5.3. Réz nanoszálak előállítása, jellemzése és elektromos tulajdonságainak vizsgálata ..64

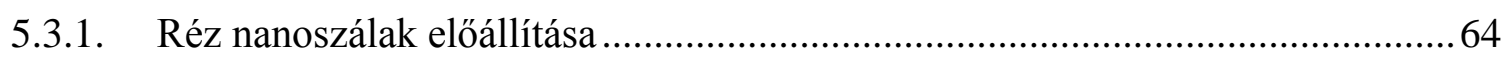

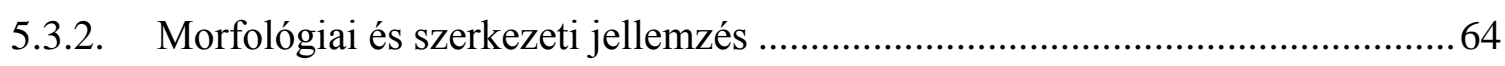

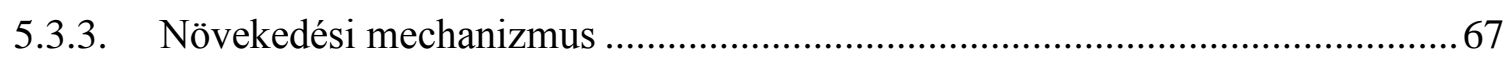

5.3.3.1. D-glükóz/réz mólarány hatása a nanoszálak képződésére .........................67

5.3.3.2. 1-hexadecil-amin/réz mólarány hatása a nanoszálak képződésére ............. 68

5.3.3.1. A nanoszálak növekedésének vizsgálata az idő függvényében ...................69

5.3.3.2. A feltételezett növekedési mechanizmus ..................................................69

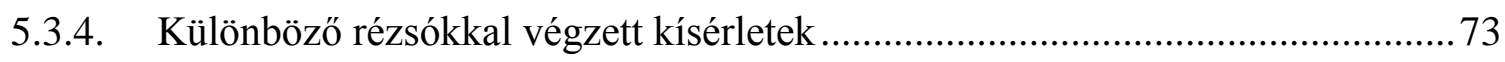

5.3.5. Klorid- és bromidionok hatása a végtermék morfológiájára .............................. 74

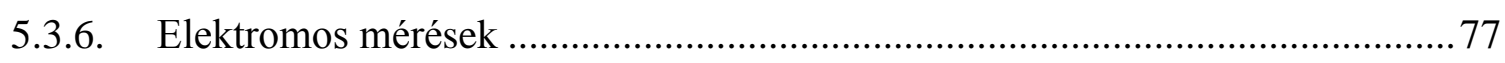

5.4. CuPt és CuPd kétfémes nanocsövek előállítása és jellemzése ...............................83

5.4.1. Kétfémes CuPt, CuPd nanocsövek előállítása................................................. 83

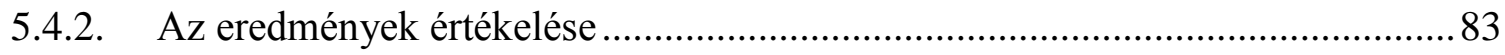

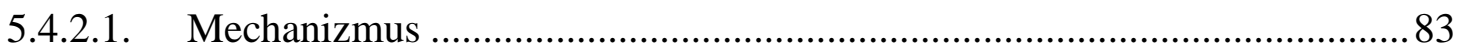

5.4.2.2. Fémtartalom meghatározása EDS-sel ................................................ 85

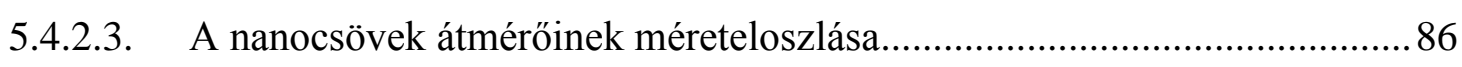

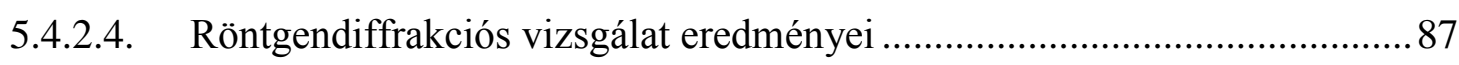

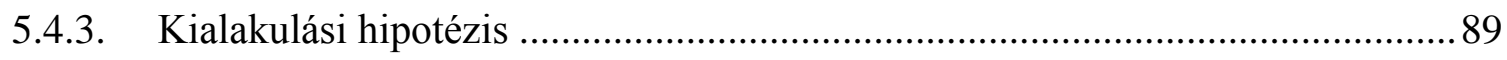




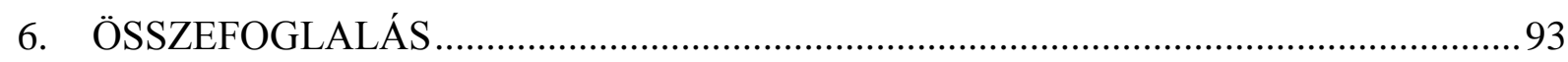

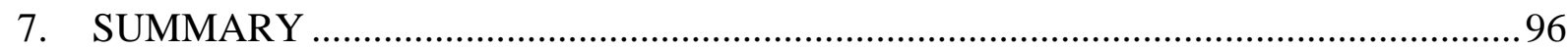

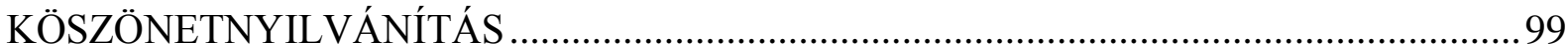

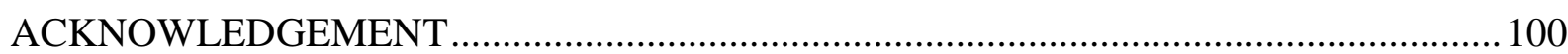

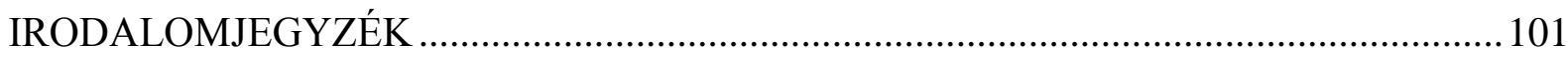




\section{ALKALMAZOTT RÖVIDÍTÉSEK}

1D egydimenziós

2D kétdimenziós

3D háromdimenziós

AOT nátrium-dioktil-szulfoszukcinát

CNT szén nanocső

CTAB cetil-trimetil-ammóniumbromid

CVD kémiai gőzleválasztás

ED elektrondiffrakció

EDS energiadiszperzív spektroszkópia

FCC lapcentrált köbös kristályszerkezet

HDA 1-hexadecil-amin

HREM nagyfelbontású elektronmikroszkópia

ITE ionbombázott membrán (ion-track-etched membranes)

MWCNT többfalú szén nanocsövek

NPs nanorészecskék

NTs nanocsövek

NWs nanoszálak

PVP polivinil-pirrolidon

SDBS nátrium-dodecil-benzol-szulfonát

SEM pásztázó elektronmikroszkópia

SEM BSE visszaszórt elektron felvétel

SHE standard hidrogénelektród

SWCNT egyfalú szén nanocsövek

TEM transzmissziós elektronmikroszkópia

TOR turnover rate - egy atomon vagy aktív helyen másodpercenként történő molekulaátalakulások száma

VVD vákuum gőzleválasztás

XPS röntgen-fotoelektron spektroszkópia

XRD röntgendiffrakció 


\section{BEVEZETÉS}

A napjainkban divatossá vált „,nano” előtag görög eredetü szó, melynek jelentése törpe. Ez az előtag az SI rendszerben a $10^{-9}$-es szorzót jelöli, mértékegysége a nanométer $(\mathrm{nm})$, amely a méter egy milliárdod része. Például egy emberi hajszál megközelítőleg 75000 nm vastag, míg egy hidrogénatom körülbelül 0,1 nm átméröjü.

Napjainkban a nanotechnológia a fizika, kémia, anyagtudomány és biológia húzóágazatává vált. A nanotudomány, nanotechnológia fogalmak pontos meghatározása és definiálása sokáig vitát váltott ki, hiszen interdiszciplináris volta révén eltérő dolgot jelentett a különböző tudományterületen dolgozó kutatók számára. A National Nanotechnology Initiative $^{l}$ a következő módon definiálta a nanotechnológia főbb jellemvonásait:

1. A nanotechnológia magába foglalja az olyan kutatást és fejlesztést, ami 1-100 nm-es mérettartományba tartozik.

2. A nanotechnológia olyan szerkezetek létrehozásával, illetve felhasználásával foglalkozik, amelyek kis méretüknek köszönhetően a tömbfázishoz képest, új (fizikai, kémiai, biológiai) tulajdonságokkal rendelkeznek. Az a méret, ahol az új tulajdonságok megjelennek, amelyek azonban az adott anyagi minőségtől és az adott tulajdonságtól is erősen függenek.

Habár maga a kifejezés relatíve újkeletü, a nanoszerkezetü anyagok és eszközök földtörténeti idejüek. Már Richard P. Feynman ${ }^{2}$ is hangsúlyozta, hogy a természet az élet kezdete óta épít müködő nanoszerkezeteket. Gondoljunk csak például az abalon (fül alakú kagyló) színjátszó héjára, amely nanoszerkezetü kálcium-karbonát „téglákból” épül fel. Nehéz adatokat találni arról, hogy az emberiség mikor kezdte el kihasználni a nanoméretü anyagok adta lehetőségeket (a fogalom pontos ismerete nélkül). Ismert azonban, hogy i. sz. 4. században római üvegművesek fém nanorészecskéket tartalmazó üvegeket készítettek. Később a 18-19. században a fotográfia kifejlődése ezüst nanorészecskék révén valósult meg. 1857-ben Michael Faraday a Philosophical Transaction of the Royal Society-ben megjelent cikkében a fém nanorészecskék vitrázs ablakok színében betöltött szerepét fejtegette. 1908ban Gustav Mie volt az első, aki feltárta a nanorészecskék ilyen jellegű tulajdonságát ${ }^{3}$.

Mérföldkőnek tekinthető a fizikai Nobel díjas Richard P. Feynman 1960-ban az American Physical Society keretein belül tartott „There is Plenty of Room at the Bottom” címü előadása, melyben a nanoméretü anyagokban rejlő potenciális lehetőségekröl beszélt. Elsőként vetette fel, hogy a méretcsökkenés révén a fizikai tulajdonságok eltérően módosulnak és ezáltal a nanoméretü anyagok a tömbfázishoz képest eltérő tulajdonságokkal 
rendelkeznek. Bár akkor ez meglehetősen fantasztikusnak tünt, a 20. század végére Feynman több elmélete beigazolódott, illetve meg is valósult ${ }^{2}$.

Az 1970-es évek elején az IBM és a Bell laboratórium megalkotta az első kétdimenziós (2D) kvantum-gödröt (quantum well). 1974-ben Norio Taniguchi először használta a „nanotechnológia” kifejezést. ${ }^{4}$ Az 1980-as években K. Eric Drexler hangsúlyozta a nanoméretü anyagok technológiai jelentőségét ${ }^{5}$. Felgyorsultak az események: 1981-ben megépült az első pásztázó alagútmikroszkóp ${ }^{6}$ (G. Binning, H. Rohrer), 1985-ben felfedezték a fulleréneket $^{7}$ (R. F. Curl Jr., H. W. Croto és R. E. Smalley), majd 1991-ben a szén nanocsöveket $^{8}$ (S. Iijima). 2004-ben Geim és kollégája Konstantin Novoselov grafént állítottak elő - amit a grafitról ragasztószalaggal választottak le - majd vizsgálták annak erősségét, átlátszóságát és elektronvezetési tulajdonságait ${ }^{9}$. Felfedezésükért 2010-ben fizikai Nobel-díjat kaptak.

A nanoszerkezetek - olyan anyagszerkezetek, amelyek legalább egy dimenzióban a nanométeres mérettartományba esnek - egyre növekvő figyelmet érdemeltek ki egyedülálló tulajdonságaiknak köszönhetően. Ma már számos nanoszerkezet megtervezésére és előállítására megvan a gyakorlati lehetőség. A szerkezetek csoportosítása attól függ, hogy az adott geometria hány irányban esik a nanométeres tartományba. A besorolás alapján léteznek nulladimenziós (0D) nanoklaszterek, kvantum dotok, egydimenziós (1D) nanoszálak, nanorudak, nanocsövek, kétdimenziós (2D) nanofilmek és háromdimenziós (3D) nanokristályos anyagok ${ }^{10}$.

A következő fejezet az 1D nanoszerkezetek legjellemzőbb tulajdonságait és leggyakoribb előállítási módszereit mutatja be. 


\section{IRODALMI ELÖZMÉNYEK}

\subsection{EGYDIMENZIÓS NANOSZERKEZETEK}

Az 1D nanoszekezetek, így a nanoszálak, nanocsövek és nanorudak, folyamatosan növekvő figyelmet érdemeltek ki egyedi tulajdonságaiknak köszönhetően. Napjainkra a modern tudomány és technológia számára igen vonzóvá vált az ilyen szerkezetek kutatása, mivel a releváns 1D szerkezetek méretének ilyen mértékü csökkenése számos új felhasználási lehetőséget rejt magában. Erre a legjobb példa a mikroelektronika területe, ahol az integrált áramkörök által elért méretcsökkenés egyben jobb tulajdonságok megjelenését is jelentette: több komponenst lapkánként, gyorsabb müködést, kisebb költséget és hatékonyabb energiafelhasználást ${ }^{11}$.

Az elmúlt években rendkívül sokféle anyagból sikerült 1D nanoszerkezeteket előállítani. Közülük kiemelt figyelmet érdemeltek ki a szén nanocsövek (CNT). A szén nanocsövek története a fullerének felfedezését követően egy japán kutató, Iijima eredményeivel kezdődött ${ }^{8}$. Egyedülálló tulajdonságaik, a velük kapcsolatban felhalmozott nagy mennyiségü adathalmaz és gyakorlati alkalmazásokban való felhasználhatóságuk napjainkra a szén nanocsöveket az 1D nanoszerkezetek prototípusává tette.

A továbbiakban részletesen bemutatom az egydimenziós nanoszerkezeteket tulajdonságait, illetve előállítási módszereit (a szén nanocsövek nem tartoznak szorosan az értekezés témájához, ezért ezeket nem tárgyalom részletesen).

\subsubsection{Egydimenziós nanoszerkezetek jellemző tulajdonságai és alkalmazásai}

Szemben a tömbfázisú anyagokkal, az 1D nanoszerkezetek nagy fajlagos felületük és a kvantumhatárolás vagy kvantum korlátozottság (quantum confinement) miatt különleges elektromos, optikai és kémiai tulajdonságokat mutatnak.

\subsubsection{Hömérsékleti stabilitás}

A nanotechnológián alapuló eszközökbe építendő nanoszálak esetén alapvető elvárás a nagy hőmérsékleti stabilitás. Ugyanakkor, mint azt a következő kísérleti eredmények mutatják, az olvadáspont drasztikusan csökken, amennyiben az adott anyag nanoméretben jelenik meg ${ }^{12}$. El-Sayed és munkatársai spektroszkópiai módszereket alkalmazva nagyszámú tanulmányban vizsgálták arany nanorudak fototermális hatásra bekövetkező olvadását és morfológiai változását ${ }^{13}$. Az arany nanorudak mérsékelt energiával rendelkező 
femtoszekundumos lézer hatására megolvadtak és gömbszerü morfológiát vettek fel. Yang szénrétegbe csomagolt Ge nanoszálak olvadását és újrakristályosodási hőmérsékletét vizsgálta. A kb. $1 \mu \mathrm{m}$ hosszú és $55 \mathrm{~nm}$ átmérőjü Ge nanoszál végei kb. $650{ }^{\circ} \mathrm{C}$-on kezdtek megolvadni. A teljes szál $848{ }^{\circ} \mathrm{C}$-on olvadt meg, ami jóval alacsonyabb, mint a tömbfázisbeli germánium $930{ }^{\circ} \mathrm{C}$-os olvadáspontja. Ezzel szemben a visszakristályosodási hőmérséklet $\left(558^{\circ} \mathrm{C}\right)$ elmaradt a kezdeti olvadási hőmérséklettől ${ }^{14}$. Megfigyelései alapján Yang sikeresen összehegesztett két Ge nanoszálat egy darab egykristályos nanoszállá.

A megfigyelt jelentős olvadáspont csökkenésnek van néhány jelentős, a további munkákban jól kihasználható következménye. Például a nanoszálak szintézise a tömbfázishoz képes jóval alacsonyabb hőmérsékleten végbemehet, továbbá az alacsonyabb olvadáspont révén lehetővé válik a nanoszálak összekapcsolása, összehegesztése, így áramkörökbe és egyéb eszközökbe való integrálhatósága.

\subsubsection{Elektrontranszport tulajdonságok}

Az 1D nanoszerkezetek vonzó tulajdonságaikat egyértelmüen egyedülálló fizikai és kémiai tulajdonságaiknak köszönhetik ${ }^{15}$. A kis átmérővel rendelkező nanoszálak kiemelkedően nagy állapotsürüségük miatt a tömbfázisú megfelelöikhez képest jelentős mértékben eltérő optikai, mágneses és elektromos tulajdonságokkal jellemezhetőek ${ }^{16} . \mathrm{Az}$ utóbbi időben megjelent publikációk, így például a fém nanoszálak ballisztikus elektron transzportjával kapcsolatos eredmények ${ }^{17}$, vagy a félvezető nanoszálakon alapuló térvezérlésű tranzisztorok (FET) megnövekedett érzékenysége és teljesítménye ${ }^{18}$ új lendületet adtak a nanoszálakon végzett kutatásoknak. Az utóbbi évtizedekben az elektronikai eszközök miniatürizálása rendkívül gyorsan haladt előre, azonban a „top-down”, azaz felülről lefelé építkező stratégia egyre inkább korlátokba ütközik, így helyét egyre inkább a „bottom-up” azaz alulról felfelé építkező stratégia veszi át. Számos eszköz prototípusa elkészült ${ }^{19-22}$, melyekben szén, fém vagy félvezető nanoszálakat használtak fel.

Napjainkra a miniatürizálás olyan mértéket ért el, hogy érdemes megvizsgálni az összetevőkben a méretcsökkenés hatására az elektrontranszport tulajdonságokban bekövetkező változásokat. Számos kutatócsoport kísérletei igazolták, hogy bizonyos fém nanoszálak félvezetővé válhatnak, amint átmérőjük egy adott érték alá csökken. Dresselhaus csoportja Bi nanoszálakon végzett mérései kimutatták, hogy a nanoszálak fém-félvezető átalakuláson mennek át, amikor átmérőjük az $52 \mathrm{~nm}$ alá csökken ${ }^{23}$. További méretcsökkenés hatására a nanoszálak akár szigetelővé is válhatnak. 


\subsubsection{Szenzorikai alkalmazások}

Az 1D nanoszerkezetek másik lehetséges felhasználási területe a környezeti, orvosi vagy biztonsági célokból fontos molekulák érzékelésére alkalmas eszközökben valósulhat $\mathrm{meg}^{24}$. A nagy felület/térfogat arány miatt a nanoszálak elektromos tulajdonságai igen érzékenyen változnak a felületükön adszorbeálódó anyagok hatására ${ }^{24}$. Tao és munkatársai azt figyelte meg, hogy az elektrokémiai módszerrel növesztett réz nanoszálakon a szerves molekulák adszorpciója és a vezetési tulajdonságok összefüggenek. Három molekula, a 2,2'-bipiridin, az adenin és a merkaptopropionsav adszorpcióját vizsgálták. Megállapították, hogy a nanoszálak elektromos vezetöképességének csökkenése függ az adszorpciós kötés erősségétöl ${ }^{25}$. Ugyanezt a felismerést alkalmazva Penner és munkatársai vékony polimerfilmre rögzített Pd nanoszálakat használtak hidrogén érzékelésére ${ }^{26}$.

\subsubsection{Egydimenziós nanoszerkezetek előállítási módszerei}

\subsubsection{1. Általános eljárások}

1D nanoszerkezetek előállítása nagyon egyszerü, ha az adott anyag anizotróp kristályszerkezettel rendelkezik szilárdfázisban. Ebben az esetben nincs jelentősége annak, hogy gőzfázisból vagy oldatból történik az előállítás. Ezzel szemben az izotróp kristályszerkezetű anyagok (például a fémek többsége) esetében a szimmetriát a nukleációs lépés folyamatában kell megtörni az anizotróp szerkezet elérése érdekében. A gócok, illetve az őket körülvevő környezet szimmetriájának csökkentésére alkalmas pl. a szilárd templátok alkalmazása, továbbá a gőz-folyadék-szilárd (VLS) fázisú reakció, ahol a szimmetriát a folyadék-szilárd határfelület töri meg. A túltelítettség meghatározott értéken való tartása is alkalmas 1D nanoszerkezetek szintézisére, amelyet a szolvotermális és a gőzfázisú eljárások használnak ki. Az ún. védőmolekulák a szilárd kristály különböző lapjainak a növekedési sebességét befolyásolják, és így érik el az anizotróp kristálynövekedést. Ebben a fejezetben olyan módszereket mutatok be, amelyek a szilárd anyag kristályszerkezeti izotrópiájától függetlenül, alkalmasak lehetnek 1D nanoszerkezetek előállítására.

\section{Gözfázisú elöállitási módszerek:}

A gőzfázisú módszer talán az egyik leginkább ismert és tárgyalt eljárás a nanorudak és nanoszálak létrehozására. Elvben ezzel az eljárással bármely szilárd anyagból lehet 1D nanoszerkezetet előállítani, ha a gőz túltelítettségét egy viszonylag alacsony értéken tartjuk. Közel 90 évvel ezelőtt Volmer és Estermann 20 nm átmérőjü és 1 mm-nél is hosszabb higany 
nanoszálakat fedezett fel, amikor a higany olvadáspontja alá hütött üveglapra higanygőzt kondenzáltatott ${ }^{27}$. Később Sears kiterjesztette ezt a módszert számos egyéb fémre, valamint egy mechanizmust is javasolt a szálak növekedésére. Elmélete szerint a növekvő nanoszál felületén adszorbeálódó atomok egy csavar mentén a szál végére vándorolnak (csavart diszlokáció - axial screw dislocation $)^{28}$. Habár Sears elmélete napjainkra sem igazolódott be teljesen, általában elfogadott, hogy az 1D nanoszerkezet kialakulásához a túltelítettség megfelelő szabályozása elengedhetetlen, hiszen a túltelítettség mértéke határozza meg az uralkodó növekedési morfológiát. Alacsony túltelítettség a nanotük (whiskers) növekedésének kedvez, ezzel szemben magasabb értékeknél tömbi kristályok alakulnak ki.

Habár a gőzfázisban megvalósuló egydimenziós növekedés pontos mechanizmusa még mindig vitatott, maga a módszer alkalmasnak bizonyult nanotűk előállítására sok anyagfajtából. Miután valószínüleg elkerülhetetlen az $\mathrm{O}_{2}$ jelenléte a rendszerben, így a reakciók többségében oxid nanotűk keletkeznek. A gőzfázisú előállítás legfőbb előnye megfelelő túltelítettségi értéknél - az egyszerüség és a nagy hozam. A reakció első lépésében a fémporból gőzt állítanak elő párologtatással vagy kémiai reakcióval, majd rávezetik egy hütött szilárd szubsztrátra, ahol az lecsapódik.

Zhang és kollégái ezzel az egyszerü eljárással sikeresen állítottak elö $\mathrm{Si}_{3} \mathrm{~N}_{4}, \mathrm{Ga}_{2} \mathrm{O}_{3}$, and $\mathrm{ZnO}$ nanoszálakat, $\mathrm{SiC}$ nanokábeleket és $\mathrm{SiO}_{2}$ amorf nanoszálakat ${ }^{29}$. A nanoszerkezetek átmérőjét jelentősen befolyásolta a szintézis hőmérséklete. Megfelelő körülmények között a nanoszerkezetek átmérője nem haladta meg a 100 nm-es nagyságot. Miután az előállítás nem igényel katalizátort, a nyert nanoszerkezetek igen tiszták voltak.

A gőzfázisú leválasztásnak számos típusa létezik, így beszélhetünk fizikai (PVD) vagy kémiai gőzleválasztásról (CVD). A PVD során szilárd- vagy folyadékfázisból, atomokból vagy molekulákból álló gőzfázist állítanak elő, amelyet alacsony nyomású $\left(10^{-2}-10^{-4} \mathrm{mbar}=\right.$ $\left.1-10^{-2} \mathrm{~Pa}\right)$ környezetben a szubsztrátra vezetnek, ahol az kicsapódik. A folyamat tisztán fizikai: magas hőmérsékletü vákuumpárologtatás vagy a katódporlasztásos plazmabombázás (plasma sputter bombardment). Napjainkra a PVD-nek több válfaja alakult ki. Ezek közé tartozik pl. az elektronsugár (EBPVD), a vákuum (VVD) vagy a pulzáló lézer (PLPVD) PVD. A PVD egyik legelterjedtebb változata a vákuum gőzleválasztás (VVD), melyet $10^{-5}-10^{-9}$ Torr $\left(1,3 \cdot 10^{-3}-1,3 \cdot 10^{-7} \mathrm{~Pa}\right)$ nyomáson végeznek, így elkerülhető a minta gázfázisból történő szennyeződése.

A PVD-vel szemben a CVD során a gázfázisban levő reagensek és a hevített hordozó között kémiai reakció megy végbe ${ }^{10}$. A magas hőmérsékleten $\left(500-1200{ }^{\circ} \mathrm{C}\right)$ redukció és/vagy bomlás játszódik le. A redukciót a bevezetett hidrogén gáz, míg a bomlást a magas 
hőmérséklet idézi elö. A CVD-nek számos fajtája létezik, mint például a fémorganikus (MOCVD), alacsony nyomású (LPCVD), vagy plazmával segített CVD (PECVD) ${ }^{30}$.

\section{Göz-folyadék-szilárd növesztésü nanoszálak}

A gőzfázisú leválasztási eljárások közül a VLS módszer a leginkább alkalmas egykristályos nanoszálak nagy mennyiségben történő előállítására. Eredetileg a VLS mechanizmust Wagner és kollégái írták le 1964-ben, amikor szilícium nanotüket növesztettek gázfázisból szilícium szubsztrátra felvitt folyékony aranycseppek jelenlétében ${ }^{31}$. Napjainkban Lieber $^{32}$, Yang ${ }^{33}$ és számos kutatócsoport ${ }^{34,35}$ foglalkozott az elmélettel szervetlen nanoszerkezetek előállítása kapcsán. A VLS eljárás (2.1. A ábra) során a gázfázisú reaktáns a nanoméretű fémkatalizátor cseppjein adszorbeálódik, majd abba bediffundál, amiből a túltelítettséget és a nukleációt követően egykristályos nanoszálak vagy nanorudak növekednek. Az egydimenziós növekedést tulajdonképpen a folyadékcseppek indukálják és vezetik. A cseppek mérete lényegében nem változik a folyamat előrehaladtával. Ebben az értelemben minden egyes csepp templátként szolgál, és így erősen szabályozza a növekvő szál laterális kiterjedését. Ehhez egy olyan oldószerre van szükség, amely képes folyékony ötvözetet létrehozni a kívánt anyaggal. Ideális esetben a két komponens eutektikus ötvözetet képez. A VLS módszer főbb lépéseit a 2.1. B ábra mutatja be a Ge nanoszálak képződése példáján.
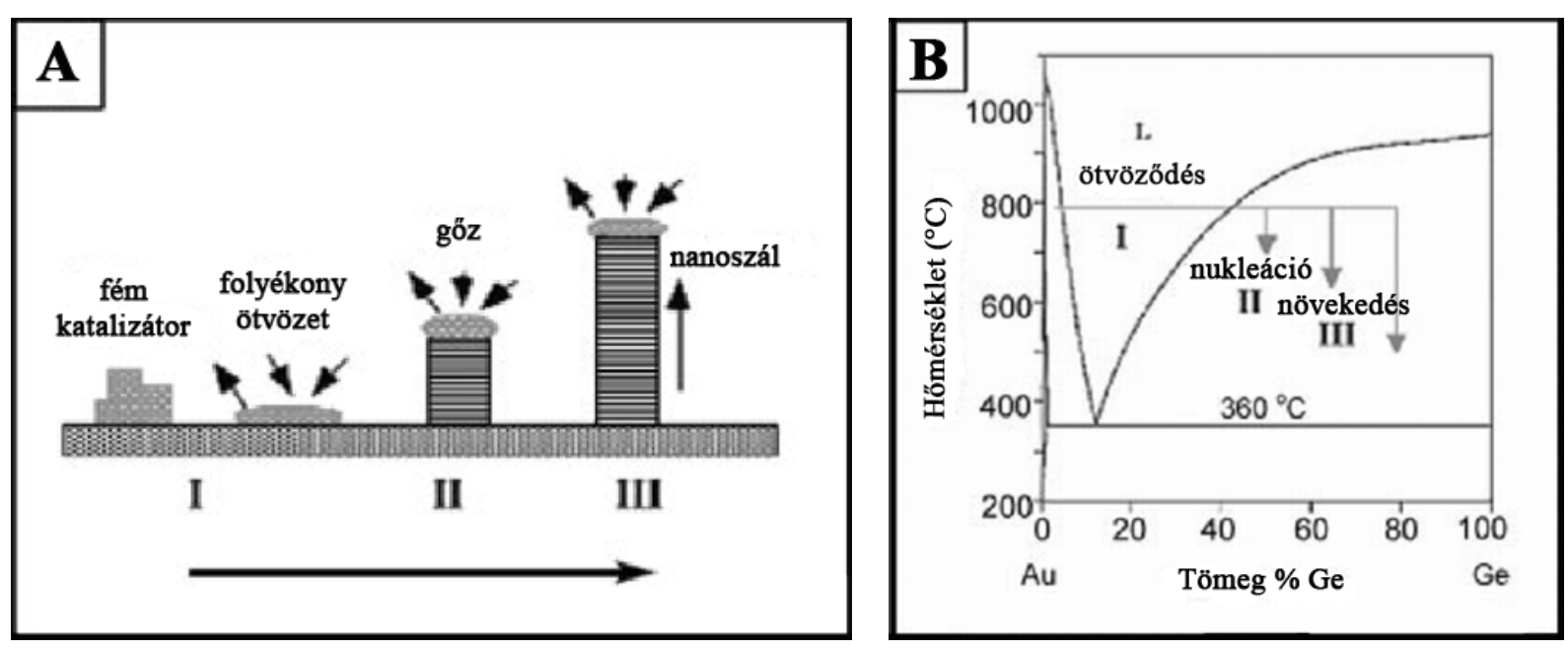

2.1. ábra: (A) Sematikus ábra VLS eljárás mechanizmusának főbb lépéseiről, (B) Au-Ge kétkomponensű rendszer fázisdiagramja ${ }^{36}$. 
A fázisdiagramon jól látható, hogy a Ge és az Au folyékony ötvözetet képez $361{ }^{\circ} \mathrm{C}$ on, valamivel az eutektikus pont felett. Amint a csepp túltelítetté válik a Ge-ra nézve, megkezdődik a nanoszálak növekedése a folyadék-szilárd határfelületen. A másodlagos nukleációs/gócképződési folyamatok elkerülése érdekében a Ge túltelítettséget megfelelően alacsony értéken kell tartani. A gőzfázis előállítására mind fizikai (lézer abláció, hőátadás, ívkisülés), mind kémiai folyamatok (gőztranszport és leválasztás) alkalmasak. A különböző módszerekkel hasonló minőségü nanoszálakat nyertek.

Yang és munkatársai Ge nanoszálak elöállításához $\mathrm{GeI}_{2}$ forrást és Au-katalizátort használtak. A gőz áramlását $700-900{ }^{\circ} \mathrm{C}$-os fütéssel biztosították. A nanoszálakat egy szabályozható hőmérsékletű mintatartóval rendelkező TEM-ben állították elő.

A legnagyobb kihívás a VLS eljárásban a megfelelő katalizátor kiválasztása. A kiválasztáshoz segítséget jelenthet a fázisdiagramok tanulmányozása. A módszer legfőbb limitáló tényezője, hogy feltételezhetően nem használható fémekre, továbbá, a fémkatalizátor elengedhetetlen használata szennyezheti a félvezető nanoszálat, megváltoztatva ezzel azok tulajdonságait.

\section{Oldat-folyadék-szilárd növesztésü nanoszálak}

A VLS eljárást alapul véve Buhro és kutatócsoportja kidolgozták az SLS módszert (2.2. A ábra), amellyel egykristályos III-V félvezető nanoszálakat állítottak elő alacsony hőmérsékleten ${ }^{37}$. A folyamathoz egy alacsony olvadáspontú fémet (pl.: In, Sn vagy Bi) alkalmaztak katalizátorként, míg a kívánt anyagot fémorganikus vegyületek bontásával nyerték.

$\mathbf{A}$
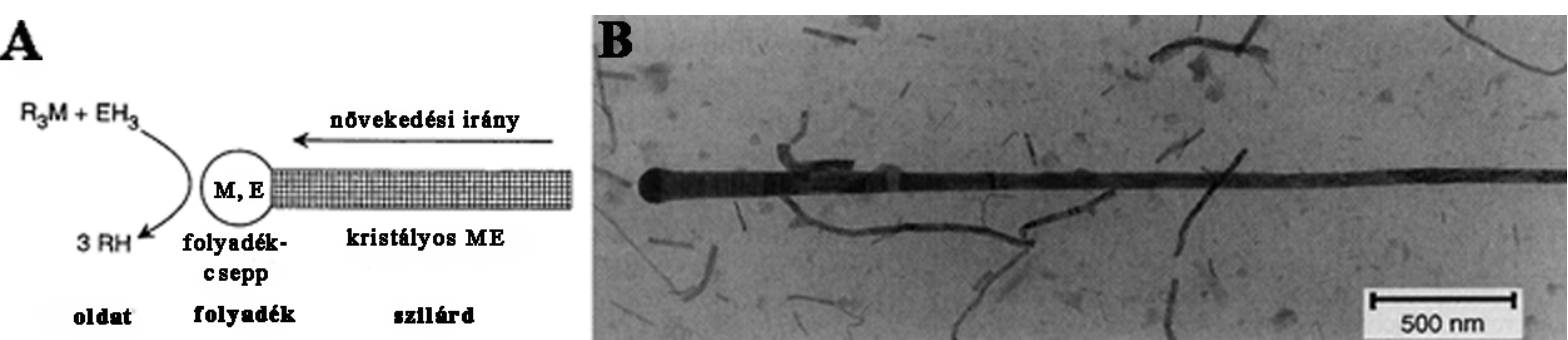

2.2. ábra: (A) Az SLS eljárás mechanizmusa: a folyadékcsepp In, M és E III-V félvezető elemek a cseppben oldva. A kristályos szál és a hozzákapcsolódó csepp a reakcióoldatban van szuszpendálva. (B) InP nanotü TEM felvétele. 
Ezzel az eljárással viszonylag alacsony hőmérsékleten $\left(\leq 203{ }^{\circ} \mathrm{C}\right) \operatorname{InP}(2.2 . B$ ábra $)$, InAs és GaAs polikristályos nanoszálakat és nanotüket állítottak elő, amelyek 10-150 nm-es vastagsággal és néhány mikrométeres hosszúsággal rendelkeztek. Az SLS eljárás előnye a VLS-sel szemben, hogy jóval alacsonyabb hőmérsékleten kivitelezhető.

\section{Szolvotermális/hidrotermális eljárás}

A hidrotermális eljárás igen népszerü módszerré vált a nanoszerkezetű anyagok elöállítására az elmúlt két évtized során. Ez az eljárás nemcsak monodiszperz, homogén nanorészecskék előállítására alkalmas, hanem nanohibrid és nanokompozit anyagok készítésére is. Maga a „hidrotermális” szó jelentése geológiai eredetü. A vizes közegben (hidrotermális) vagy egyéb oldószerben (szolvotermális) kivitelezett eljárás lényege az 1 atmnál nagyobb nyomáson és $25^{\circ} \mathrm{C}$-nál magasabb hőmérsékleten lejátszódó heterogén kémiai reakció $^{38}$. A szolvotermális eljárás során gyakran az oldószer kritikus pontja feletti hőmérsékletet és nyomást alkalmaznak, amely elősegíti a szilárd anyagok oldódását és a felgyorsítja a köztük lejátszódó reakciót. Az első lépésben általában a prekurzor anyagból és a reagensből megfelelö összetételü oldatot készítenek. A reagensek olyan anyagok (pl. aminok), amelyek képesek szabályozni a kristálynövekedést vagy templátként funkcionálni a folyamat során. Ezt követően autoklávban magas hőmérsékletnek és nyomásnak teszik ki az oldatot, amíg a nanoszálak ki nem alakulnak. Az eljárás legfőbb előnye az, hogy a megfelelő oldószerben szinte bármely anyag oldatba vihető elegendően nagy nyomáson és hőmérsékleten, azaz a módszer jól alkalmazható a legtöbb szilárd anyagra ${ }^{24}$.

A 90-es évek elején Heath és kollégái elsőként alkalmazták a szolvotermális módszert félvezető nanoszálak előállítására ${ }^{39}$. Germániumból 7-30 nm-es, $10 \mu \mathrm{m}$-nél hosszabb egykristályos nanoszálakat állítottak elő $\mathrm{GeCl}_{4}$ illetve fenil- $\mathrm{GeCl}_{3}$ redukciójával, $275^{\circ} \mathrm{C}$-on és 100 atm nyomáson.

Meg kell jegyezni, hogy a szolvotermális eljárás nanoszálképzési mechanizmusának szisztematikus vizsgálatát jelentősen megnehezíti, hogy a módszer során használt autoklávban nem egyszerü a különböző paraméterek követése.

\section{Védőmolekulákon alapuló oldatfázisú módszerek}

Egy kristály alakját döntően a kristályt alkotó kristálylapokhoz kapcsolódó relatív fajlagos felületi energia határozza meg. A Wulff-szabály szerint az egyensúlyi helyzetben a kristályt olyan kristálylapok határolják, melyekre a kristály (összes) felületi többletenergiája 
minimálisnak adódik ${ }^{40,41}$. Ennek megfelelően az egykristályos nanoszerkezetek alakja árulkodik az őt alkotó anyag kristályrácsáról (a legtöbb fém esetében ez kocka és nem szál vagy rúd). A kristály alakja a növekedés kinetikájára utalhat, hiszen a gyorsan növekvő kristálysíkok eltünnek és a lassan növekvők maradnak vissza ${ }^{42}$. Ugyanakkor így lehetővé válik a kristályok alakjának befolyásolása megfelelő mennyiségű védőmolekulával. Ezek a különböző kristály felszínek szabad energiájának megváltoztatásával, azok növekedési sebességét is meghatározzák. Nagyszámú olyan anyagot ismerünk, amely képes ilyen jellegü változásokat előidézni ${ }^{43-46}$. Például a PVP oxigénatomjai az Ag és a Pd $\{100\}$ kristálylapjaihoz kapcsolódnak szorosan ${ }^{47}$. A nanokristály növekedése során az atomok a kevésbé passzivált kristálylapokhoz kapcsolódnak. A $\mathrm{Br}^{-}$-ion is képes szelektíven adszorbeálódni az Ag, Au, Pt és Pd $\{100\}$ kristálylapjain $^{48}$. Érdemes megemlíteni, hogy a $\mathrm{Br}^{-}$-ion jelen lehet szennyezőanyagként sok oldószerben, illetve az ellenionként gyakran alkalmazott ionos felületaktív anyagokban (pl.: CTAB). A fent említettekkel szemben a citrátion az $\{111\}$ kristálylapokon szeret adszorbeálódni, elősegítve ezzel az oktaéder, ikozaéder vagy a dekaéder formák kialakulását ${ }^{49,50}$.

Habár a védőmolekulák és ionok jelentősen befolyásolják a jelenlétükben kialakuló nanokristályok alakját, ennek ellenére a folyamatban betöltött pontos szerepük és maga a folyamat mechanizmusa csak hiányosan ismert ${ }^{51}$.

A

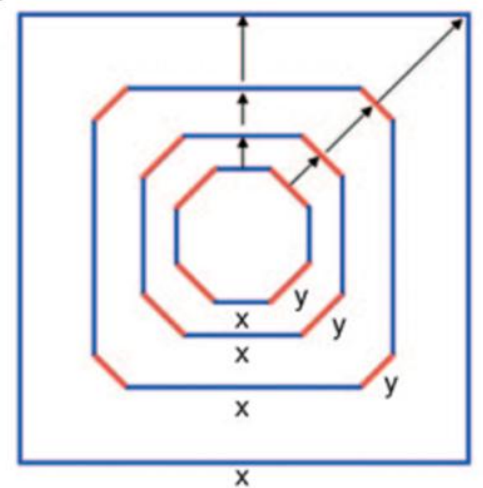

B

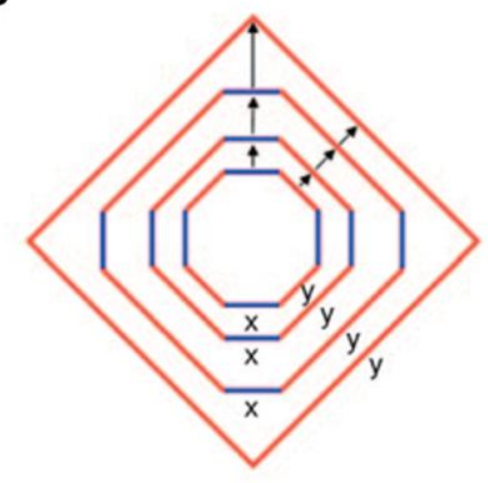

2.3. ábra: Képzeletbeli kétdimenziós nyolcszög növekedési lépései. (A) Az y oldalak gyors növekedése az (x oldalakhoz viszonyítva) az y oldalak eltünését eredményezi, (B) vica versa. A nyilak hossza arányos a növekedési sebességgel ${ }^{51}$.

A nanokristály megjelenési formáját meghatározza a kristálylapok relatív növekedési sebessége. Ha egy képzeletbeli kétdimenziós nyolcszöget (2.3. ábra) rendre lassú és gyorsan növekvő oldalakkal képzelünk el, előbb-utóbb egy olyan négyszöget kapunk, amelyben 
eltűntek a gyorsan növekvő oldalak. Ha ezt három dimenzióban képzeljük el úgy, hogy a gyorsan növekvő kristálylapok a kubooktaéder „lecsapott” csúcsai, akkor a növekedés „végére” egy hexaédert kapunk. Ha viszont a kubooktaéder oldal lapjai növekednek gyorsan, akkor lassan növekvő lapokkal határolt oktaéder alakul ki.

Xia és kollégái ezüst nanoszálakat állítottak elő ezüst-nitrát redukciójával etilénglikol és PVP jelenlétében ${ }^{52-54}$. Az ún. poliol módszer során a PVP mint védőmolekula vesz részt. $\mathrm{Az}$ ezüst-nitrát redukciójakor bimodiális részecskeméret eloszlással rendelkező $\mathrm{Ag}$ nanorészecskék keletkeznek, majd a nagyobb részecskék további növekedése figyelhető meg az Ostwald-féle érés szerint, a kisebb részecskék rovására. A PVP segítségével a részecskék növekedése szabályozható, így egységes átmérővel rendelkező nanoszálak jönnek létre.

A fém nanoszálak nagy mennyiségben történő előállíthatósága jelentős hatással lehet az elektronikai iparra. A polimerekbe kevert fémek mennyisége jelentős mértékben csökkenthető lenne nagy hossz/átmérő aránnyal rendelkező nanoszálak használatával ${ }^{55}$. Így nemcsak a felhasznált fém mennyisége hanem az elektronikai eszköz tömege is nagymértékben csökkenne. Ezen túlmenően ezek a nanoszálak az elektrokémiai analízis és detektálás területén nanoelektródként is használhatók ${ }^{24}$.

\subsubsection{Anizotrop kristályszerkezettel rendelkező anyagok}

Számos olyan szilárd anyag létezik, amely természeténél fogva nő 1D nanostruktúrába rendeződve. Ez a kristályszerkezetben rejlő erős anizotrópia következménye. Talán a legjobb példa erre a poli(tiazil), (SN) , ami egy az 1970-es években intenzíven kutatott szervetlen vezető polimer ${ }^{56}$. (A kutatás furcsa iróniája, hogy abban az időben komoly erőfeszítéseket tettek annak érdekében, hogy minél nagyobb egykristályokat növesszenek.)

Az anizotróp növekedés jellemző a szelénre, tellúrra valamint az általuk képzett sókra, a kalkogenidekre, így például a $\mathrm{M}_{2} \mathrm{Mo}_{6} \mathrm{X}_{6}(\mathrm{M}=\mathrm{Li}, \mathrm{Na} ; \mathrm{X}=\mathrm{Se}, \mathrm{Te})$ összetételü anyagokra. $\mathrm{Az}$ oxigéncsoport (vagy kalkogéncsoport) elemei, pontosabban a Se, és a Te, ideális elemek 1D morfológiával rendelkező nanostruktúrák kialakítására. Ennek a két anyagnak a trigonális (t-) rendszere egyedülálló kristályszerkezetet mondhat magáénak. Az oxigénnel ellentétben, amely elsősorban az $\mathrm{O}_{2}$-molekulaként fordul elő, a Se és a Te atomjai hajlamosak kovalens kötésekkel, helikális alakban összekapcsolódni ${ }^{57}$. Amint a 2.4. A ábra is mutatja, a helikális lánc könnyedén kialakul hexagonális rendszerben van der Waals kötések révén ${ }^{24}$. A felsoroltak alapján ez a két anyag erősen hajlamos 1D szerkezetekbe (2.4. B ábra) 
kristályosodni még izotróp közegben is. A Se és Te nanoszerkezeteket nagy intenzitással kutatják a természetes anizotrópiából fakadó érdekes tulajdonságaik miatt.
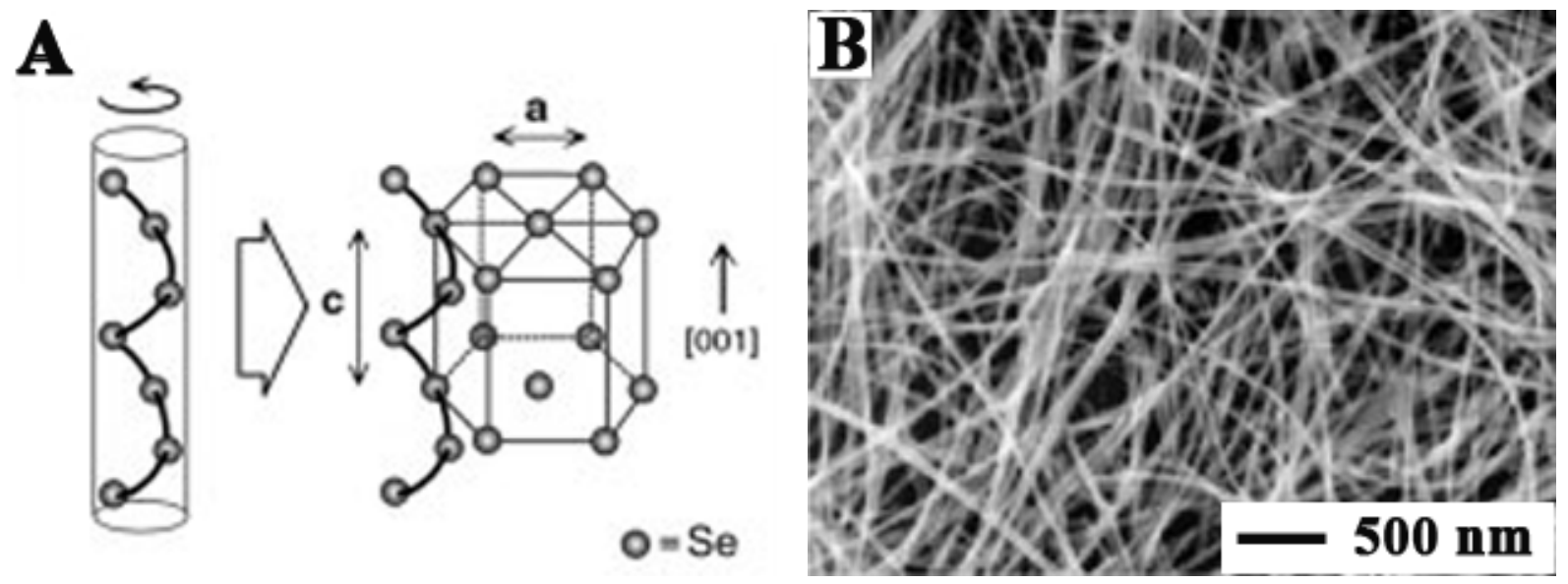

2.4. ábra: (A) A c-tengely mentén párhuzamosan rendeződött helikális láncokból kialakuló hexagonális szerkezet, (B) pásztázó elektronmikroszkópos felvétel a t-Se nanoszálakról ${ }^{58}$.

Xia és munkatársai kidolgoztak egy egyszerü módszert mikrométeres hosszúságú és 10-100 nm-es vastagságú t-Se nanoszálak előállítására. Az első lépésben 300 nm-es, szilárd amorf szelén (a-Se) kristályokat állítottak elő szelénessav és hidrazin reakciójával, magas hőmérsékleten. A lehülés során az oldott formában jelen lévő Se kivált t-Se formában. Az oldatot ezt követően sötétben tárolták, ahol az Ostwald-féle érés következtében az amorf formában jelen lévő szelén lassan visszaoldódott, és t-Se formában kristályosodott ki ${ }^{59}$. Hasonló nanoszálak állíthatóak elő tellurból ${ }^{60}$ és szelén/tellúr ${ }^{61}$ ötvözetböl is.

\subsubsection{Templátok által elösegített elöállítás}

Micellák, mint templátok - Önrendezödö molekuláris szerkezetek

A mezofázist önrendeződéssel létrehozó felületaktív anyagok, mint templátok alkalmazhatóak 1D nanoszerkezetek nagy mennyiségben történő előállítására. Mint ismeretes, a felületaktív anyagok egy kritikus koncentrációt elérve $(\mathrm{cmc})$ micellákat formálnak ${ }^{62}$. Ezek a struktúrák kémiai vagy elektrokémiai reakcióval összekapcsolva alkalmasak 1D nanoszerkezetek előállítására. Gyakran alkalmazott kationos tenzidek a kvaterner ammónium vegyületek, például a cetil-trimetil-ammónium-bromid (CTAB) és a tetraoktil-ammoniumbromid (TOAB). Anionos tenzidként a nátrium-dioktil-szulfoszukcinátot (AOT) alkalmazzák 
előszeretettel. A tenzideken túlmenően megfelelő körülmények között a blokk ko-polimerek is alkalmasak szabályos elrendeződésre és hengeres szerkezet kialakítására.

$\mathrm{Az}$ önrendeződő szerkezetek révén előállítható 1D nanoszerkezetek többnyire polikristályos szerkezetủek. További probléma, hogy fém nanoszálak előállítása során gyakran igen nehézkes és időigényes a micellák létrehozása, illetve eltávolítása ${ }^{24}$.

\section{Pórusos anyagok csatornai, mint templátok}

Az 1D nanoszálak egyik leggyakrabban alkalmazott előállítási módja a pórusos anyagok csatornáit, mint templátot használja a növesztés során. Ezt a módszert széles körben alkalmazzák, egyszerűségének és sokoldalúságának köszönhetően. Templátok segítségével könnyen állíthatunk elő különféle átmérővel és hosszúsággal rendelkező fém nanoszálakat (pl.: Ni, Fe, Co stb. $)^{63,64}$. Számos pórusos anyagot, így zeolitokat ${ }^{65,66}$ és mezopórusos szilikátokat (SBA-család, M41S-család), használnak és használtak nanorudak és nanoszálak előállítására. Közülük az anódosan oxidált alumínium-oxid membrán (AAO) és az ion bombázott polimer membrán (ITE) használata terjedt el a leginkább.

\section{- Mezopórusos szilikák}

A mezopórusos szilikák használata fizikai templátként szintén felmerült a kutatók körében ${ }^{67-69}$. Ezek közül az M41S (pl. MCM-41) és az SBA család (pl. SBA-15) tünt a legalkalmasabbnak egydimenziós nanoszerkezetek növesztésére. Az 1D nanoszerkezetek előállítása ebben az esetben három lépésből tevődik össze. Az első lépés során a pórusos anyagot a prekurzor anyag gőzével vagy oldatával átitatják, majd ezt követően átalakítják a prekurzor anyagot a kívánt anyaggá (pl. hőkezeléssel). Az utolsó lépésben szelektíven eltávolítják a pórusos anyagot. Ezzel a módszerrel nemesfém nanoszálakat (pl. Ag, Au, Pt és Pd) és ötvözeteket (pl. Au/Pt) állítottak elő. Az eljárás legnagyobb hátránya, hogy szinte kizárólag kis hossz/átmérő aránnyal rendelkező polikristályos nanoszálak előállítására alkalmas.

\section{- $\quad$ Anódos alumínium-oxid membrán}

$\mathrm{Az}$ alumínium korrózióvédelmére, illetve felületén való nanoléptékü szerkezet kialakítására már évtizedek óta alkalmaznak elektrokémiai folyamatokat ${ }^{70,71}$. A rendezett pórusrendszerrel rendelkező anódos alumínium-oxid előállítását Masuda és Fukoda írta le először 1995-ben ${ }^{72}$. Ez az anyag az elmúlt évtizedekben igen nagy figyelmet érdemelt ki a tudományos körökben. A membrán rendezett pórusrendszerét alumínium fólián, kétlépéses 
anodizálási folyamat révén alakították ki. Az anodizálás megkezdése előtt a vékony, nagytisztaságú alumíniumfóliát felhevítik, majd elektrolitikus polírozással eltávolítják a felületen lévő alumínium-oxid réteget. Az anodizálás első lépése során savas elektrolitban, konstans feszültség mellett végezik az anodizálást. Ezt követően lemaratják az alumíniumoxid réteget kromát oldatban, így egy pretexturált alumínium fóliát kapnak, amely elősegíti a szabályos nanopórusok kialakulását a második lépés során. A második anodizálást az elsőhöz hasonlóan savas elektrolitban végzik. Végül eltávolítják az alumínium réteget. A templát tulajdonságai könnyen befolyásolhatóak a reakció paramétereinek módosításával ${ }^{73}$. A pórusok átmérője és a cellák mérete leginkább az első lépés során alkalmazott elektrolit, hőmérséklet, anodizáló feszültség, míg a pórusok mélysége az anodizálás idejének megválasztásával befolyásolható ${ }^{64}$. Eltérő elektrolitoldatokat használva, különböző hőmérsékleten és feszültség mellett eltérő pórusátmérők alakíthatók ki. Így például, kénsav, oxálsav vagy foszforsav jelenlétében 5-33 nm, 30-70 nm, vagy 150-267 nm közötti pórusokat szintetizálhatók ${ }^{73}$.
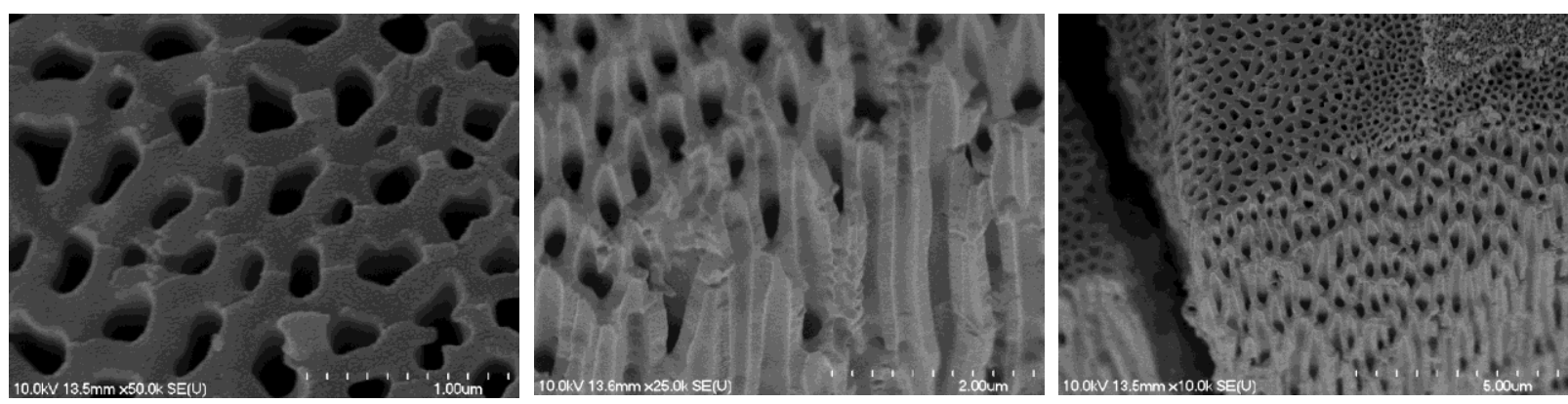

2.5. ábra: Whatman ${ }^{\circledR}$ anódos alumínium-oxid membrán pásztázó elektronmikroszkópos felvétele.

A membránban a csatornák nagyjából hexagonális rendezettségűek, és a membrán felszínére merőlegesen közel párhuzamosan futnak (2.5. ábra). A pórusok mérete igen széles mérettartományban szabályozható $(5-267 \mathrm{~nm})^{72,74}$. A már említett SBA és M41S családoktól eltérően az anódos alumínium-oxid membránban nincs összeköttetés az egyes csatornák között, és a pórussürüség megközelítőleg $10^{10}-10^{11}$ pórus $/ \mathrm{cm}^{2}$. A polikarbonát membránok pórussürüsége két nagyságrenddel kisebb ${ }^{75}$.

- Ionbombázott pórusos polimer membránok

Az ion bombázott pórusos polimer membránok (ITE - Ion-track-etched Polymer Membranes) általában kereskedelmi forgalomban szintén megtalálható szürőmembránok, amelyeket polikarbonát vagy poliészter filmekből készítenek ${ }^{73,76,77}$. A filmeket először ionokkal bombázzák, amelyek véletlenszerüen elhelyezkedő csatornákat formálnak keresztül 
a membránban. Ezt követően kémiai maratással egységes pórusokat alakítanak ki, amelyek átmérője $10 \mathrm{~nm}$-től $2000 \mathrm{~nm}$-ig terjedhet. Ezzel a módszerrel $\mathrm{kb} .10^{8}-10^{9}$ pórus $/ \mathrm{cm}^{2}$ pórussűrűség érhető el. A pórusok véletlenszerű kialakulása a csatornák kereszteződéséhez vezethet, amely kihatással van a bennük képződő nanoszerkezetek homogenitására ${ }^{78}$.

Bár az ITE membránok is elterjedtek nanoszálak előállítására ${ }^{79}$, mégis az anódos alumínium-oxid membrán a legkedveltebb templát, amelyet az 1D nanoszerkezetek elektrokémiai előállítása során használnak.

\section{Elektrokémiai leválasztás}

Az elektrokémiai leválasztás esetében a leválasztási paraméterek ( $\mathrm{pH}$, hőmérséklet, leválasztási potenciál) megválasztásával befolyásolható a nanoszálak morfológiája és szerkezete $^{74}$. A leválasztást megelőzően a membrán alsó oldalára egy fémréteget párologtatnak. Ez a vezető réteg mint katód funkcionál az elektrokémiai leválasztás folyamatában.

Az előbbiekben tárgyalt membránok és az elektrokémiai leválasztás kombinációja egy igen hatékony és eredményes módszer 1D nanoszerkezetek és nagy rendezettségü nanoszerkezetű kompozitok előállítására ${ }^{80,81}$. A a módszer nem igényel költséges müszert, gyors, a folyamat során nincs szükség magas hőmérsékletre és alacsony nyomásra sem. Megváltoztatva az elektrolitoldatot és a leválasztás feszültségét, akár eltérő szegmensekből álló nanoszálakat is előállíthatunk.
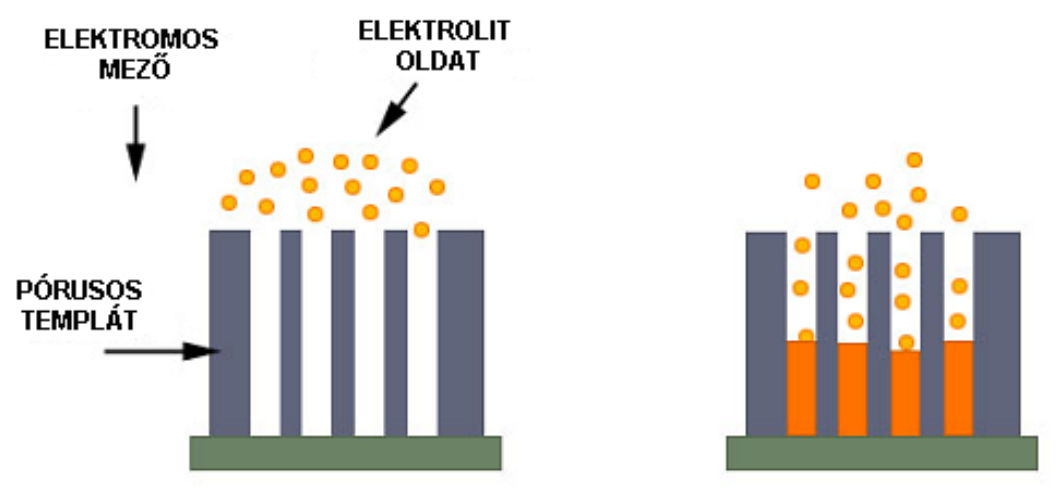

2.6. ábra: Sematikus ábra az elektrokémiai leválasztásról.

A leválasztás (2.6. ábra), szinte függetlenül az anyagi minőségtől, különböző anyagok esetén igen hasonlóan müködik. Az első lépés során egy fémréteget párologtatnak a 
templátként alkalmazott membrán egyik oldalára. Ez a fémréteg munkaelektródként funkcionál a leválasztás során. A kívánt fém pórusokba történő leválasztását megelőzően általában valamilyen egyéb fémet választanak le, hogy megelőzzék az ún. „puddleing” hatást, nehogy a nanoszálaknak deformált végük képződjön. Ezt követően leválasztják a kívánt fémet a pórusokba. A folyamat végeztével eltávolítják a munkaelektród réteget és a templátot.

$\mathrm{Az}$ első templátba történő elektrokémiai fémleválasztást Possin és munkatársai végezték 1970-ben ${ }^{65}$. Kísérleteikben Zn, Sn, és In nanoszálakat állítottak elő, amelyhez ITE réteges szilikátot használtak fel. Azonban az általuk bemutatott módszer csak később, Martin és munkatársai ${ }^{74,76,77}$, valamint Moskovitz $^{82}$ által terjedt el és vált igazán ismerté. A módszerek mindegyikében három elektróddal ellátott elektrokémiai cellában, negatív potenciált alkalmazva, elektrolitoldatból választják le az adott fémet a templát pórusaiba. A nanoszálak átmérőjét a templátként alkalmazott anyag pórusai szabják meg, míg a szálak hossza a Faraday törvény által leírt módon közvetlen kapcsolatban áll a rendszeren átfolyt negatív töltés mennyiségével ${ }^{78}$. Az első áttörő kísérleteket követően sokféle fémből (pl. $\mathrm{Au}^{76}$, $\mathrm{Ni}^{66}, \mathrm{Bi}, \mathrm{Pb}^{83}, \mathrm{Cu}^{84}$ stb.) állítottak elő nanoszálakat templátokban történő leválasztás útján.

\subsubsection{Elöre szintetizált nanoszerkezetek, mint templátok}

Az előállított nanostruktúrák alkalmasak lehetnek, mint templátok, olyan anyagok nanoszerkezetü előállítására, amelyeket egyébként csak körülményesen vagy egyáltalán nem lehet előállítani egységes morfológiával rendelkező nanostruktúrákban. Ezzel a módszerrel például 1D nanoszerkezetek bevonásával koaxiális kábelszerü nanoszerkezeteket állíthatunk elő. A szintézist követően a templátként alkalmazott nanoszál feloldásával nanocsöveket készíthetünk $^{85}$. Akár a layer-by-layer ${ }^{86}$ vagy a szol-gél ${ }^{87}$ módszer is alkalmas lehet nanokábelek vagy kompozit nanocsövek előállítására. Xia és kollégái szol-gél módszerrel $\mathrm{Ag} / \mathrm{SiO}_{2}$ nanokábeleket állítottak elő, ezüst nanoszálak szilika rétegbe való csomagolásával. Az ezüst nanoszálak ammónia oldatban való szelektív feloldása egységes szerkezetü szilika nanocsöveket eredményezett ${ }^{87}$.

A nanoszálakon túlmenően Ajayan és munkatársai ${ }^{88}$ szén nanocsöveket használtak templátként nanorudak és nanocsövek növesztésére különböző anyagokból. Dai ${ }^{89}$ sikeresen állított elő $\mathrm{Au}, \mathrm{Pd}, \mathrm{Fe}, \mathrm{Al}$ és $\mathrm{Pb}$ nanoszálakat direkt gőzleválasztás útján. A reakciót megelőzően titánt választott le a szén nanocsövek felületére, ami nedvesíti a csövek felületét, így erősen befolyásolja az összefüggő fémbevonat képződését. Mivel napjainkban már több mm hosszúságú CNT-ket ${ }^{90}$ növesztenek, így ez a módszer alkalmas lehet mm hosszúságú fém nanoszálak kialakítására. 
A fent említetteken túl számos oldatfázisú reakció alkalmas már meglévő 1D nanostruktúrák átalakítására. A galvanikus fémcsere helyettesítési reakcióval ezüst nanoszálakból $\mathrm{Au}, \mathrm{Pd}$ és Pt nanocsövek állíthatóak elö ${ }^{91}$. A standard elektródpotenciál különbségek miatt a reakció önként végbemegy, az ezüst nanoszálak és a nemesfém-só vizes oldata között. A módszert részletesebben a 2.3 fejezetben mutatom be.

A fent említett eljárások mellett érdemes megemlíteni azt a módszert, amellyel szobahőmérsékleten egykristályos $\mathrm{Ag}_{2} \mathrm{Se}$ nanoszálak hozhatók létre t-Se nanoszálak és $\mathrm{AgNO}_{3}$-oldat reakciójával ${ }^{92}$. Ebben az eljárásban az ezüstionok bediffundálnak a Se rácsába és $\mathrm{Ag}_{2} \mathrm{Se}$-det képeznek anélkül, hogy jelentősen átrendeznék a Se-atomokat. Megfigyelték, hogy a 40 nm-nél kisebb átmérőjü nanoszálak tetragonális, a vastagabbak rombos kristályszerkezettel rendelkeznek ${ }^{93}$.

A nanoszálak templátként történő alkalmazása egy általános és hatékony eljárás, amely egységes 1D nanoszerkezetek előállítását teszi lehetővé sokféle anyag esetében ${ }^{24} \mathrm{Az}$ előre szintetizált templátos módszer nagy hibája azonban, hogy a termék pontos összetétele és kristályossága nehezen befolyásolható, valamint a módszerek többnyire polikristályos szerkezetet eredményeznek, és csak néhány bizonyult alkalmasnak egykristályos nanoszerkezetek előállítására.

\subsubsection{Fém nanokristályok alakját befolyásoló ionok, védőmolekulák}

A kristálygócok (,nuclei”), a szintézis legelső fázisában néhány atom vagy ion összekapcsolódásával alakul ki. Bár még vitatott, hogy hogyan képződik a nanokristály a prekurzor molekulákból, az elfogadott tény, hogy a prekurzor bomlásával vagy redukciójával jönnek létre a 0 oxidációs állapotú fématomok. LaMer és munkatársai által az '50-es évek elején bemutatott elméletet a 2.7. A ábra mutatja be ${ }^{94}$. A prekurzor bomlása esetén amint az atomok száma elér egy bizonyos túltelítettségi értéket $\left(c_{\min }^{n u}\right)$, megindul az atomok kis kristálygócokká történő aggregációja, a nukleációo ${ }^{94}$. Ezt követően a kis kristálygócok gyorsan növekednek egészen addig, amíg az atomok száma az oldatban le nem csökken egy adott túltelítettségi érték alá. Amennyiben van utánpótlás, a kristálygóc tovább növekszik és nanokristállyá fejlődik. Ez a folyamat addig tart, amíg be nem áll az egyensúlyi helyzet a nanokristály felületi és oldott atomjai között. A kristálygócok és/vagy nanokristályok agglomerálódásával nagyobb objektumok is létrejöhetnek ${ }^{95}$.

A prekurzor redukciójával előállított nanokristályok esetében még vitatott, hogy a képződő atomok vagy az ionok kapcsolódnak össze kristálygócként. Platina nanorészecskék 
előállításakor néhány munka igazolta, hogy a prekurzor komponensek össze tudnak kapcsolódni a 0 oxidációs állapot elérése előtt ${ }^{96}$. A kialakuló trimer és dimer egységek nagyobb elektronaffinitással bírnak, mint a prekurzor molekulák, így ezek nagyobb eséllyel fognak redukálódni. Ez a mechanizmus azonban csak meghatározott körülmények, enyhe redukálószer és/vagy nagy prekurzorkoncentráció esetén jellemző. Ebben az esetben nem szükséges, hogy a kristálygóchoz újonnan kapcsolódó egység atom legyen. Sőt, a képződő klaszter vagy nanokristály felületén is lehetnek töltéssel rendelkező fémionok, amelyeket ligandumok vagy az oldószer molekulái szolvatáció útján stabilizálnak. Egy ilyen egyedi, határfelületi szerkezettel bíró kristály magyarázatot adhat egyes ionok úgy, mint $\mathrm{pl} . \mathrm{Cl}^{-}, \mathrm{Br}^{-}$ és citrát, valamint polimerek által mutatott „lefedö hatásokra” (,capping effect”).

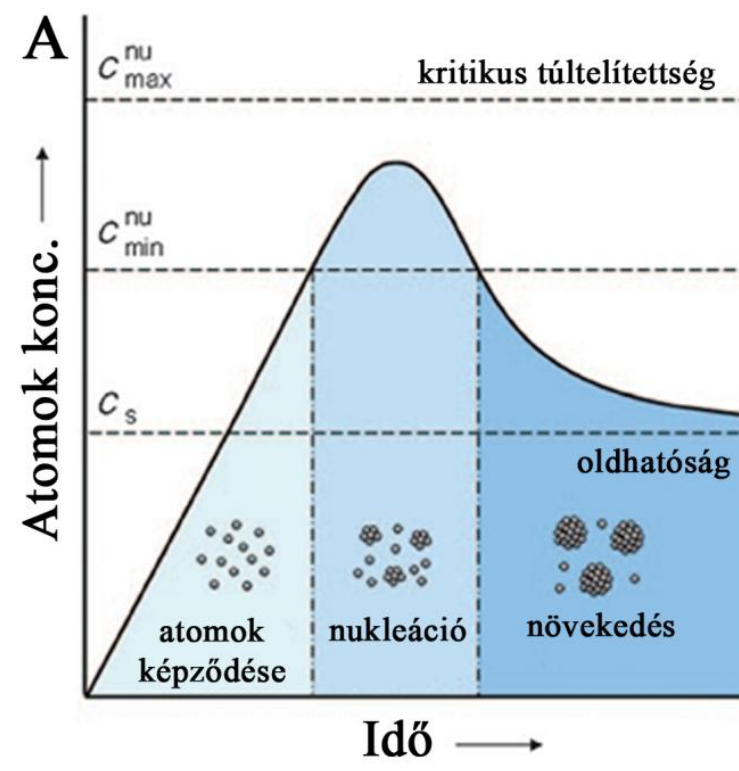

B

\section{7. ábra: (A) Nanokristályok kialakulásának mechanizmusa LaMer szerint ${ }^{94}$. (B) Tetraéderekből álló dekaéder.}

Abban a pillanatban, amikor a kristálygóc/kis klaszter elér egy adott méretet, egy energetikailag kedvező, jól meghatározott alakot vesz fel, melyet kristálymagnak (seed) hívnak. A kristálymagok lehetnek egykristályok, egyszeres ikerkristályok (singly twinned) és többszörös ikrek (multiply twinned). Ezek egyszerre is jelen lehetnek egy adott szintézis során. Ahhoz, hogy egyféle alakú nanokristályokat kapjunk, az előállítás során erősen kontrolálnunk kell a kialakuló kristálymagok szerkezetét termodinamikai és kinetikai tényezők helyes megválasztásával.

Oxidativ maratás (oxidative etching) esetében a kép még bonyolultabbá válik. 
Amennyiben a reakció termodinamikai kontrol alatt van, az a legstabilabb termék képződését segíti elő. Ebben az esetben, a Wulff-szabályt is figyelembe véve, olyan egykristályok képződnek, amelyek minimális határfelületi energiával rendelkeznek adott térfogatra vonatkoztatva. A határfelületi szabad energiát, $\gamma$, értelmezhetjük úgy is, hogy az egy egységnyi „új” felszín (A) létrehozásához szükséges energiamennyiség. G a szabadenergia.

$$
\gamma=\left(\frac{\partial \mathrm{G}}{\partial \mathrm{A}}\right)_{\mathrm{n}^{\mathrm{i}}, \mathrm{T}, \mathrm{P}}
$$

Ugyanakkor a felületi feszültség leírható az alábbi egyenlettel is, ahol $\mathrm{N}_{\mathrm{b}}$ a felszínről hiányzó kötések száma, $\varepsilon$ a kötéserősség, $\rho_{a}$ a felszíni atomok sűrüsége ${ }^{42,97}$.

$$
\gamma=\frac{1}{2} N_{b} \varepsilon \rho_{a}
$$

Egy fcc kristályszerkezetet jellemzően határoló, alacsony indexü kristálylapok energiái a következőképpen alakulnak: $\gamma\{111\}<\gamma\{100\}<\gamma\{110\}$. Ennek megfelelően az egykristály oktaéder vagy tetraéder formát felvéve tudja maximalizálni az $\{111\}$ lapok jelenlétét és minimalizálni a teljes felületi energiáját. Ugyanakkor térfogatra vonatkoztatva mindkét forma nagyobb felülettel rendelkezik, mint egy köbös szerkezet. A fentiek eredményeként az egykristály $\{111\}$ és $\{100\}$ lapokkal határolt csonkított oktaéder (vagy Wulff poliéder) formát vesz fel.

Az ikerkristályos kristálymagok esetében is hasonló a helyzet. Az egyszeres iker kristálymagot szintén $\{111\}$ kristálylapok határolják, hogy a teljes határfelületi szabad energia a lehető legkisebb legyen. A többszörös ikerkristályok képződése egyre nagyobb feszültséget idéz elő a kristályrácsban. Az ötszörös ikerkristály, a dekaéder, öt darab tetraéder egykristály összenövéséből áll (2.7. $B$ ábra $)^{98}$. Minden egyes tetraéder két $\{111\}$ ikersíkon keresztül érintkezik a szomszédos tetraéderrel. Azonban a tetraéder két $\{111\}$ kristálylapja által bezárt szög $70,53^{\circ}$, így a $7,35^{\circ}$ rést kompenzálni kell a tetraéderek határain lévő atomoknak. Ez az atomok közti kötések megnyúlásához vezet, ami belső feszültséget okoz a rácsban és egy rendezetlen (defekt) régió kialakulását segíti elő a tetraéderek határain ${ }^{99,100}$. A kristálymag növekedésével a legyezőszerü konfigurációban a defekt régió egyre növekszik, amely a kristály teljes szabadenergiájának növekedését okozza. Ezért a többszörös ikerkristály csak viszonylag kis méretben stabilis. Ferrando és kollégái kimutatták, hogy az fcc fémek 
esetében az ikozaéder csak nagyon kis méretekben, a dekaéder közepes méretekben stabilis. Nagyobb méretű kristályok esetén a Wulff poliéder biztosít stabilis formát ${ }^{51}$. Természetesen az átmeneti pontok az anyagi minőségtől is függenek. Ez az erős függés a mérettől azt sugallja, hogy a kristálymagok eloszlását nemcsak a termodinamika szabja meg. A kristálymagok eloszlása a reakció kinetikájától is függ, amely kísérletileg befolyásolható.

A többszörös ikerkristályok rácsában fellépő feszültséget a kristály $\{111\}$ lapokkal kompenzálja ${ }^{101}$. Ahogy a kristálymag egyre növekszik, a kristály egyre kevésbé képes fenntartani ezt az állapotot, ezért egykristállyá ${ }^{51,101,102}$ alakul át. Ebből következik, hogyha a kristálymagok többszörös ikerkristályos formáinak mennyiségét szeretnénk növelni, akkor az újabb atomok képződését és/vagy azok a kristályba való beépülését kell lelassítani. Ebben az esetben a kristálymagok nagy részét a többszörös ikrek fogják alkotni szemben az egykristályokkal, hiszen ezek hosszú ideig stabilisak ilyen kis méretben. Természetesen egyszeres ikerkristályok is lesznek a kristálymagok között, de csak kis mennyiségben, amely a nagyobb energiával rendelkező $\{100\}$ lapoknak köszönhető. Lényegében a prekurzor redukciójának vagy bomlásának sebességét változtatva befolyásolhatjuk a képződő kristálymagok kristályszerkezetét.

Amennyiben a redukció vagy a bomlás sebessége megfelelően alacsony értékre csökken, a képződő kristálygócok és kristálymagok random hexagonális szoros illeszkedésü rácsban (random hexagonal close packing - rhcp) fognak kristályosodni, amely rétegzödési hibákat (stacking fault) is tartalmazhat ${ }^{103}$. Ezt a fajta szintézist, kinetikailag szabályozottnak nevezik, mert a termodinamika által megszabott alaktól eltérő (nagyobb energiájú) kristálymagok előállítására alkalmas. A rétegződési hibák és az ikerkristályosság táblaszerü (plate-like) formákat hozhat létre. Ezzel az alakkal rendelkező kristálymagok jóval nagyobb energiával rendelkeznek, mint ami termodinamikailag kedvező lenne. Gyakorlatban a kinetikailag szabályozott alakkal rendelkező kristálymagokat többféle módon is elérhetjük: 1) nagymértékben szabályozott prekurzorbomlás vagy redukció ${ }^{104}$,2) gyenge redukáló szer alkalmazása, 3) a redukciós folyamat összekapcsolása egy oxidációs folyamattal, 4) Ostwaldféle érés kiaknázása. Kulcsfontosságú, hogy a fématomok képződését az oldatban eléggé lelassítsuk, így a kristálygócok nem lesznek képesek autokatalitikus úton növekedni poliéder formába, hanem a táblaszerủ szerkezet éleihez fognak kapcsolódni.

Az egykristályos és ikerkristályos kristálymagok eloszlása az oxidatív maratással (oxidative etching) is szabályozható, amely a 0 oxidációs állapotú fématomokat visszaoxidálja ionokká ${ }^{105}$. 


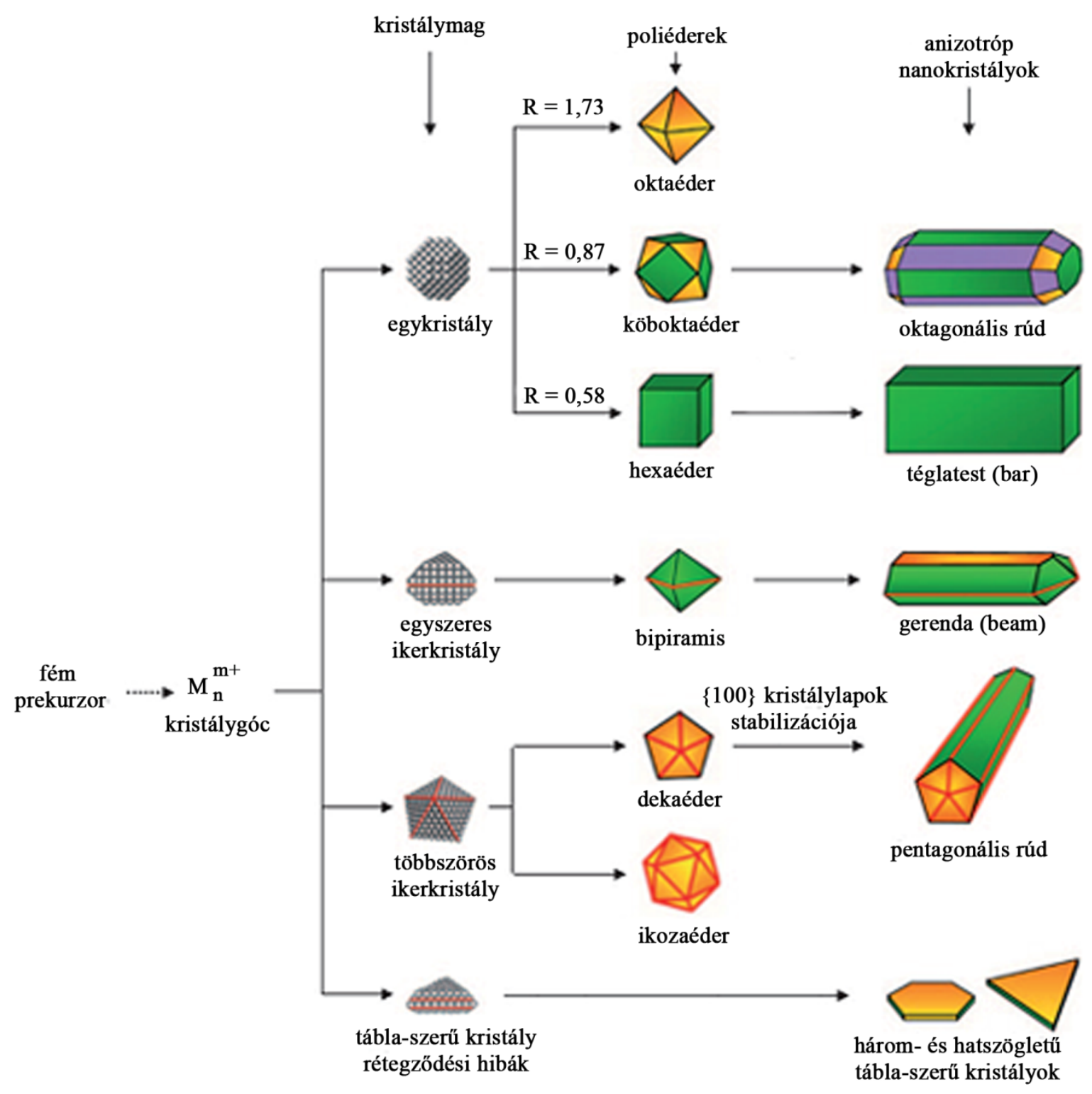

2.8. ábra: FCC kristályszerkezettel rendelkező fémek kristálygócaiból fejlődő kristálymagok és nanokristályok. A zöld, sárga és lila színek az $\{100\},\{111\}$, és $\{110\}$ kristálylapokat reprezentálják. Az ikersíkokat piros vonalak választják el. $A z$ " $R$ " paraméter $a z<100>$ és $<111>$ irányú növekedés aránya ${ }^{51}$.

Mivel a legtöbb szintézis levegőn megy, az oxigén hatása végig érvényesül a reakció során. Amennyiben a fémion valamely liganduma is jelen van az oldatban, a ligandum és az $\mathrm{O}_{2}$ együtt egy erős marószerként fog viselkedni a kristálygócok és a kristálymagok számára. Mivel az ikerkristályok hibazónáinak atomjai nagyobb energiával rendelkeznek, mint az egykristály atomjai, ezért sokkal érzékenyebbek az oxidatív környezetre, és oxidálódni fognak. Ez a jelenség lehetővé teszi, hogy az ikerkristályos kristálygócokat és kristálymagokat szelektíven „eltávolítsuk” az oldatból. Például Ag nanokristályok poliol módszerrel történő előállításakor elenyésző mennyiségben adott $\mathrm{Cl}^{-}$-ion segítségével az ikerkristályos 
kristálymagok eltávolíthatóak szinte teljes mértékben ${ }^{105}$. Amennyiben a $\mathrm{Cl}^{-}$-ion helyett egy kevésbé korrozív aniont, $\mathrm{Br}^{-}$-ot alkalmazunk, csak a többszörös ikerkristályos kristálymagokat távolíthatjuk el ${ }^{106}$. A folyamat jelentősége abban rejlik, hogy ezek a magok nagyon eltérő morfológiájú nanokristályokat eredményeznek. Abban az esetben, ha a többszörös ikerkristályos kristálymagokat szeretnék megtartani, több megoldás is szóba jöhet: 1) inert gázt áramoltatva át az oldaton, kiűzhetjük az $\mathrm{O}_{2}-\mathrm{t}^{107,108} 2$ ) megfelelő védőmolekulával (pl. citrát) megakadályozhatjuk az oxigén adszorpcióját ${ }^{49} 3$ ) egy redox párral (pl. $\mathrm{Fe}^{\mathrm{III}} / \mathrm{Fe}^{\mathrm{II}}$ vagy $\left.\mathrm{Cu}^{\mathrm{II}} / \mathrm{Cu}^{\mathrm{I}}\right)$ megköthetjük az $\mathrm{O}_{2}-\mathrm{t}^{108,109}$.

A kristálymagokból nanokristály növekedését a rácsenergia (növekedésnek kedvez) és a felületi energia (az oldódásnak kedvez) közti versengés határozza meg. A 2.8. ábra a kristálymagok és azokból kialakuló nanokristályok alakja közti összefüggést mutatja be fcc fémek esetében. Általában egykristályos kristálymagból oktaéder, kuboktaéder vagy hexaéder képződik az $<111>$ és $<100>$ kristálylapok növekedési arányának függvényében ${ }^{42}$. Anizotróp növekedés esetén ezekből oktagonális és négyszögletủ nanorudak növekednek ${ }^{48}$. Egyszeres ikerkristályos kristálymagokból $\{100\}$ kristálylapokkal határolt bipiramis ${ }^{110}$, míg a többszörös ikerkristályos magokból dekaéder és ikozaéder növekszik ${ }^{111}$. A dekaéderből anizotróp növekedés révén pentagonális rúd alakul $\mathrm{ki}^{48,111,112}$. A rétegződési hibákat tartalmazó kristálymagokból lapos alakzatok jönnek létre, amelyek tetejét és alját $\{111\}$, oldalát $\{111\}$ és $\{100\}$ kristálylapok határolják. Természetesen ezek csak a legtipikusabb formákat mutatják be egy meghatározott rendszerben. A nanokristályok ettől eltérő alakúak is lehetnek védőmolekulák, kristályhibák, oxidatív maratás stb. jelenléte miatt. A védőmolekulák nanokristályok alakjában betöltött szerepét a 2.1.2.1 fejezetben már tárgyaltuk. 


\subsection{EGYDIMENZIÓS RÉZ NANOSZERKEZETEK ELŐÁLLÍTÁSI MÓDSZEREI}

Napjainkra a rézszál valószínüleg az egyik leggyakrabban alkalmazott fémszálak közé tartozik. Kiemelkedő elektromos vezetőképességének köszönhetően az elmúlt évtizedekben különös figyelmet érdemelt ki, ezért a mikroelektronikai ipar területén nagyon keresett ${ }^{113}$. A réz nanoszerkezetet várhatóan az elektromos áramköröktől kezdődően a tápegységeken át széles körben alkalmazhatóak lesznek. Ezen túlmenően az 1D réz nanoszerkezetek egyedülálló elektromos- és hővezetőképességi tulajdonságai révén további felhasználási területek hasznos építőelemeivé válhatnak ${ }^{113}$. A réz nanoszerkezetek leginkább elterjedt felhasználási területei a nanoméreteken alapuló elektronikai, mágneses és optoelektronikai eszközökben valósulhat meg. A lehetséges heterogén katalitikus alkalmazások területén Somorjai és munkatársai úttörő heterogén katalitikus kutatásokat végeztek szabályozott morfológiával és oxidációs állapottal rendelkező réz nanoszerkezeteken ${ }^{114,115}$. Eredményeik elöretörést jelentenek a réz felületkémiájának feltérképezésében ${ }^{116}$, valamint a modellkatalizátorok és a valós heterogén katalitikus rendszerek közti rés áthidalásában ${ }^{117}$.

Napjainkra nyilvánvalóvá vált, hogy a fém nanoszerkezetek tulajdonságait méretük, alakjuk, kristályszerkezetük és kémiai összetételük nagymértékben befolyásolja ${ }^{118}$, így érthető, hogy jelentős erőket koncentráltak a meghatározott alakkal és mérettel rendelkező nanoszerkezetek fizikai és kémiai tulajdonságainak feltárására. Néhány kivételtől eltekintve (pl.: vákuum gőzleválasztás ${ }^{119}$ ) a kontrolált nanoszálak szintézise leggyakrabban fizikai templátok vagy felületeken erősen adszorbeálódó védőmolekulák (amelyek általában szerves polimerek vagy felületaktív anyagok) jelenlétében megvalósított kristálynövesztéssel vihető végbe. A különböző alkalmazások megkövetelik az egységes szerkezetü és nagy hossz/átmérő aránnyal rendelkező nanoszálakat, így ezek egyszerü, de nagy mennyiségben történő előállítására alkalmas módszerre van igazán kereslet.

Réz nanoszálak előállítására számos eljárás létezik, így például a kémiai gőzleválasztás $^{120}$, elektrokémiai leválasztás ${ }^{79,121}$, templát és membrán segítségével történő előállítás ${ }^{84,122,123}$, inverz micellák használata ${ }^{124,125}$ stb.

\subsubsection{Templátok segítségével történő előállítás}

\subsubsection{Elektrokémiai leválasztás pórusos templátokba}

Valószínüleg a templátokban történő elektrokémiai leválasztás a legelterjedtebb előállítási módszer ${ }^{126,127}$, mivel így viszonylag könnyen szabályozható a nanoszálak morfológiája (2.9. ábra), hossza, kristályszerkezete és alkalmas poli- és egykristályos minták 
előállítására is ${ }^{128}$. Ugyanakkor az eljárás általában sok lépésből áll és a módszer csak kismennyiségü minta előállítására alkalmas.

Elektrokémiai leválasztáshoz leggyakrabban anódos alumínium-oxidot ${ }^{84,127}$ vagy ionbombázott pórusos polimer membránokat ${ }^{79,113,121,126,128-130}$ alkalmaznak. Zhang és kollégái 2001-ben sikeresen állítottak elő $\mathrm{Cu}$ nanoszálakat elektrokémiai leválasztással anódos alumínium-oxid templátban ${ }^{127}$. Az általuk előállított nanoszálak $60 \mathrm{~nm}$ átmérőjűek és egykristályos szerkezettel rendelkeznek. A $\mathrm{Cu}^{2+}$ ionok katódon történő kiválásakor egy bizonyos nagyságú túlfeszültség ${ }^{131}$ szükséges a nukleációhoz és a szál növekedéséhez. Azonban a magasabb túlfeszültség megnöveli ugyan a nukleáció sebességét ${ }^{131}$,ami gyorsabb növekedéshez vezet, de polikristályos szerkezetet eredményez.

Darmstadti kutatók pórusos polikarbonát membránt használtak templátként, melyben a pórusokat ionbombázással és az azt követő kémiai maratással állították elő. Az elektrokémiai folyamat során katódként a templát egyik felére felvitt aranyréteget alkalmaztak. Elektrolitként $\mathrm{CuSO}_{4}$-oldatot használtak ${ }^{79}$.

A templátokban történő elektrokémiai leválasztás egyik kiemelkedő előnye a nanoszálak rendezettsége, ugyanakkor hátránya hogy a szálak gyakran defektes részeket tartalmaznak $^{119}$.
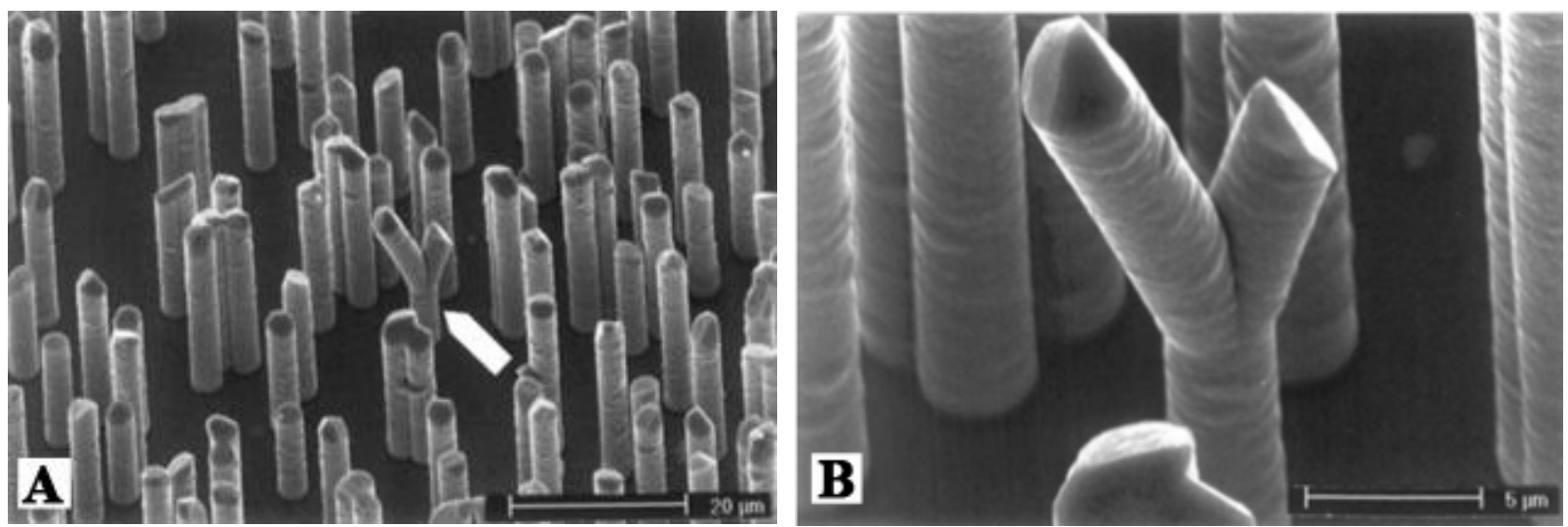

2.9. ábra: Ionbombázott pórusos polimer membránban növesztett Cu nanoszálak (A) áttekintő kép, (B) elágazó réz nanoszál ${ }^{126}$.

\subsubsection{Micellák, mint szerkezetirányító struktúrák}

Filankembo és Pileni egy olyan eljárást dolgoztak ki, melyben a réz nanoszerkezetek előállítására az $(\mathrm{AOT})_{2}$-izooktán-víz rendszerben kialakított micellákat használták fel. Kimutatták, hogy a nanoszerkezetek alakját az előállítás folyamán a rendszerhez adott sók $\left(\mathrm{NaCl}, \mathrm{KCl}, \mathrm{NaBr}, \mathrm{KBr}, \mathrm{NaNO}_{3}, \mathrm{KNO}_{3}, \mathrm{NaHSO}_{3}\right.$ ) befolyásolják anélkül, hogy a templát 
megváltozna ${ }^{124}$. Korábban feltételezték, hogy a rendszerhez adott sók hatása a Hofmeister sorozattal magyarázható, amely szerint különböző anionok és kationok eltérően befolyásolják a szerves molekulák vizes közegben történő oldódását. A különböző morfológiájú nanoszerkezetek kialakulásáért az anionok víz-AOT határfelületen kifejtett hatását tették felelőssé. Később módosították elméletüket, és a morfológiai változást az anionok eltérő kristálylapokon történő szelektív adszorpciójával magyarázták ${ }^{132}$.

Wang és munkatársai sikeresen állítottak elő $\mathrm{Cu}, \mathrm{Cu}_{2} \mathrm{O}, \mathrm{CuO}$ nanorudakat és nanocsöveket. A folyamatban minden esetben $\mathrm{Cu}(\mathrm{OH})_{4}{ }^{2-}$ volt a prekurzor és CTAB a szerkezetirányító molekula. $\mathrm{A} \mathrm{Cu}$ és $\mathrm{Cu}_{2} \mathrm{O}$ nanoszerkezetek előállításához hidrazin monohidrátot és glükózt alkalmaztak, míg a $\mathrm{CuO}$ nanoszerkezeteket hidrotermális úton állították elő. Alacsony prekurzorkoncentráció esetén nanocsövek, míg magasabb rézhidroxid koncentráció esetén nanorudak képződtek ${ }^{133}$.

\subsection{2. Ívkisülésen alapuló eljárás}

Setlur és munkatársai 1996-ban egy ívkisülésen alapuló, érdekes eljárást fejlesztettek ki nagymennyiségű szén nanocsőbe „csapdázott” réz nanoszál (2.10. A ábra) előállítására ${ }^{134}$. Az előállításhoz policiklikus aromás szénhidrogéneket $(\mathrm{PAH})$ és réz nanorészecskéket használnak prekurzorként. A reakciót néhány száz Torr hidrogén jelenlétében végzik. Elektródként két darab $10 \mathrm{~mm}$ átmérőjü grafitrudat alkalmaznak. Az anódban lévő $2 \mathrm{~cm}$ mély, $6 \mathrm{~mm}$ átmérőjü furatba egy rézrudat helyeznek. Az ívet egyenáramú tápegységgel ( 100 A, 20 V) hozzák létre. Feltételezhetően az ív magas hőmérsékletének hatására a fém a szénnel együtt elpárolog, és egy katalitikus folyamat során képződnek ezek az új nanostruktúrák.
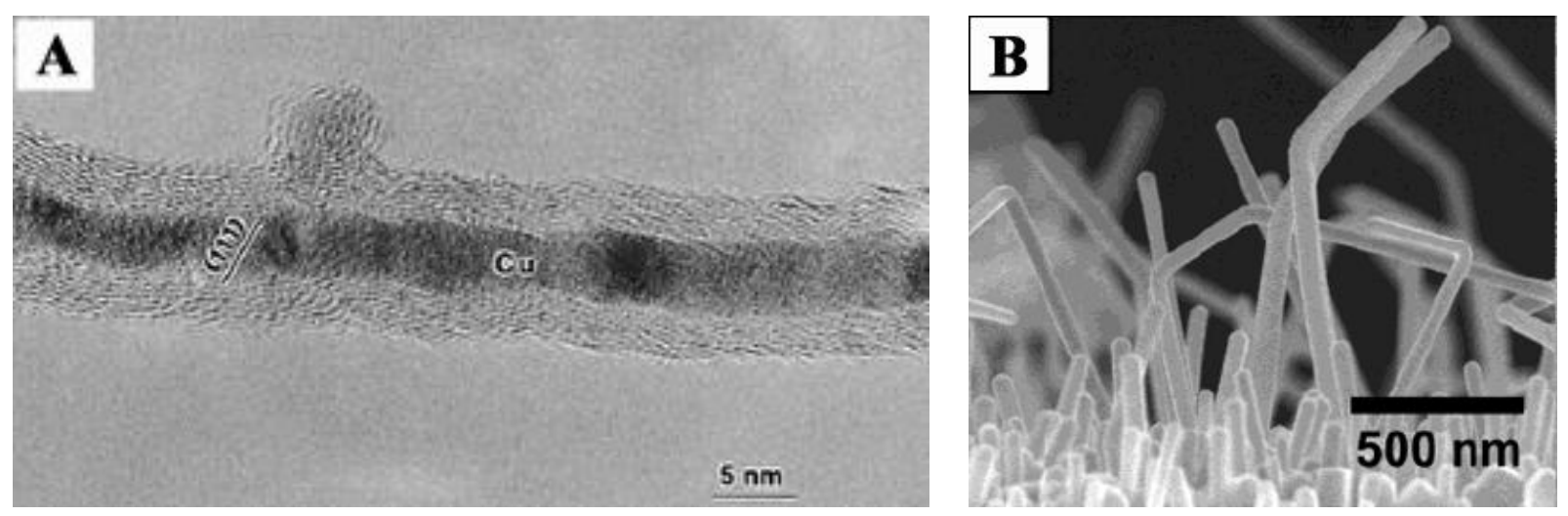

2.10. ábra: (A) HREM felvétel CNT-be „csapdázott” réz nanoszálról ${ }^{134}$, (B) SEM felvétel CVD-vel elóálított réz nanoszálakról ${ }^{120}$. 


\subsubsection{Gôzfázisú leválasztási módszerek}

\subsubsection{Kémiai gözleválasztás (Chemical Vapour Deposition-CVD)}

Réz nanoszálak gőzfázisból történő leválasztásra ${ }^{120,135}$ is nagyszámú példát találhatunk az irodalomban. A Choi és Park által kidolgozott módszer nem igényel sem templátot, sem katalizátort. Ezzel a kémiai gőzleválasztáson alapuló módszerrel szabadon álló réz nanoszálakat (2.10. B ábra) állíthatunk elő alacsony hőmérsékleten. Az eljárás alapja az, hogy eltérő hőmérsékleti stabilitással rendelkező prekurzorokat ( $\mathrm{Cu}(\mathrm{I})$ komplexeket) $\mathrm{Si}(111)$ szubsztráton, $200-300{ }^{\circ} \mathrm{C}$-on és $0,1-1,0$ Torr nyomáson kezelnek. A kémiai gőzleválasztást hidegfalú üveg reaktorban végzik ${ }^{120}$.

\subsubsection{Vákuum gözleválasżtás (Vacuum Vapour Deposition - VVD)}

Liu és Bando egy új módszert dolgozott ki réz nanorudak és nanoszálak előállítására ${ }^{119}$. A folyamat első lépésében elpárologtatják a rezet, amit a második lépésben alacsony nyomáson vagy vákuumban lecsapatnak egy szubsztrátra. A kutatók a felfedezésre egy in situ TEM vizsgálat során bukkantak rá, amikor felfütötték a réz mintatartó rostélyt. Habár a réz olvadáspontja $1083^{\circ} \mathrm{C}$, megfigyeléseik alapján az alacsony nyomás miatt a réz már $800{ }^{\circ} \mathrm{C}$-on párologni kezdett ${ }^{136}$. Az így elpárologtatott réz a viszonylag alacsony hőmérsékletű pontokon (szén filmen) vált le és nőtt szál (2.11. A ábra) alakba. A nanorudak leginkább a rostély rácsaitól távol alakultak ki, ahol feltételezhetően alacsonyabb hőmérséklet uralkodik a szén gyenge hővezető képességének köszönhetően.
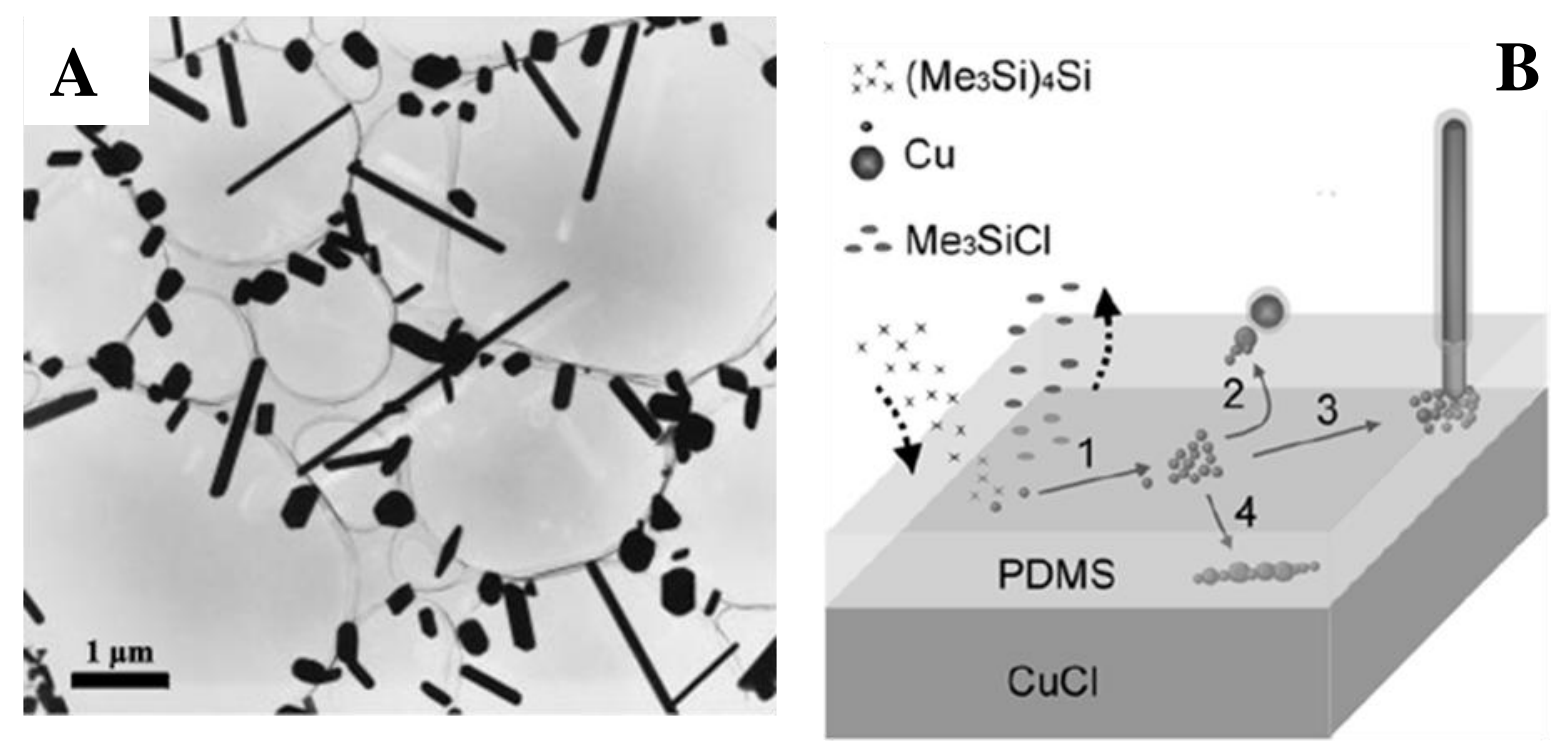

2.11. ábra: (A) VVD módszerrel előállított réz nanoszerkezetek ${ }^{136}$ és (B) a VSRG módszer. 


\subsubsection{Göz-Szilárd fázisú reakció (Vapour-Solid Reaction Growth-VSRG)}

Chiu és kollégái dolgozták ki a VSRG-nek nevezett módszert $\mathrm{Cu}$ nanoszálak előállítására ${ }^{123}$, amelynek lépéseit a 2.11. B ábra mutatja be. Az első lépésben a $\left(\mathrm{Me}_{3} \mathrm{Si}\right)_{4} \mathrm{Si}$ molekulák a PDMS membránban a $\mathrm{CuCl}$ részecskékhez diffundálnak. Az adszorpciót követően a felületi reakció során klórszilán $\left(\mathrm{Me}_{3} \mathrm{SiCl}\right)$ és $\mathrm{Cu}$ képződik, utóbbiból réz nanorészecskék formálódnak. Feltételezhetően $200{ }^{\circ} \mathrm{C}$-on a $\mathrm{Cu}$ nanoszerkezetek folyadék állapotban vannak jelen, amely lehetővé teszi számukra, hogy a felszínen diffúzióval mozogjanak és izotrópikus növekedéssel nagyobb részecskékké (2. lépés) vagy anizotrópikus növekedés által nanoszálakká (3. és 4. lépés) alakuljanak át.

\subsubsection{Kémiai módszerek}

Wang és kollégái anódos alumínium-oxid templátot használtak $\mathrm{Co}$, $\mathrm{Ni}$ és $\mathrm{Cu}$ nanocsövek előállítására ${ }^{137}$. A módszer lépéseit a 2.12. ábra mutatja be. Az első lépés során a pórusok felületét hidroxilálják, majd 3-amino-propil-trietoxi szilánnal (APTES) szilanizálják.

Ezt követően a membrán külső felületét megcsiszolják, hogy megelőzzék a fémbevonat képződését. A harmadik lépésben $\mathrm{Sn}^{2+}$ ionokkal érzékenyítetik a pórusok felszínét, amelyek komplexet képeznek az APTES aminocsoportjával. Az érzékenyített felszínt $\mathrm{Pb}^{2+}$-ionokkal aktiválják. Ekkor egy redoxi reakció játszódik le az ón- és az ólomionok közt, amely révén ólom nanorészecskék képződnek a pórusfalakon. A nanorészecskék katalizátorként vesznek részt a leválasztási reakcióban. Az utolsó lépésben a templátot egy fémoldatba helyezik, amely a réz nanocsövek előállítása esetében réz-szulfátot, kálium-nátrium-tartarátot és formaldehidet tartalmaz.

$$
2 \mathrm{Cu}^{2+}+\mathrm{N}_{2} \mathrm{H}_{4}+4 \mathrm{OH}^{-} \rightarrow 2 \mathrm{Cu}+\mathrm{N}_{2}+4 \mathrm{H}_{2} \mathrm{O}
$$

1. egyenlet: A Zeng által kidolgozott módszer során lejátszódó reakció egyenlete.

Zeng által kidolgozott módszer egy redoxi reakcióra (1. egyenlet) épül, amely lúgos körülmények között játszódik le ${ }^{138}$. A nanoszálak átméröje a 60-160 nm tartományba esik, míg hosszuk meghaladja a $40 \mu \mathrm{m}$-t. A határolt területủ elektrondiffrakciós mintázatok alapján a nanoszálak egykristályosak. A termék morfológiájának biztosítása szempontjából elengedhetetlen az etilén-diamin (EDA) jelenléte a reakció során. 


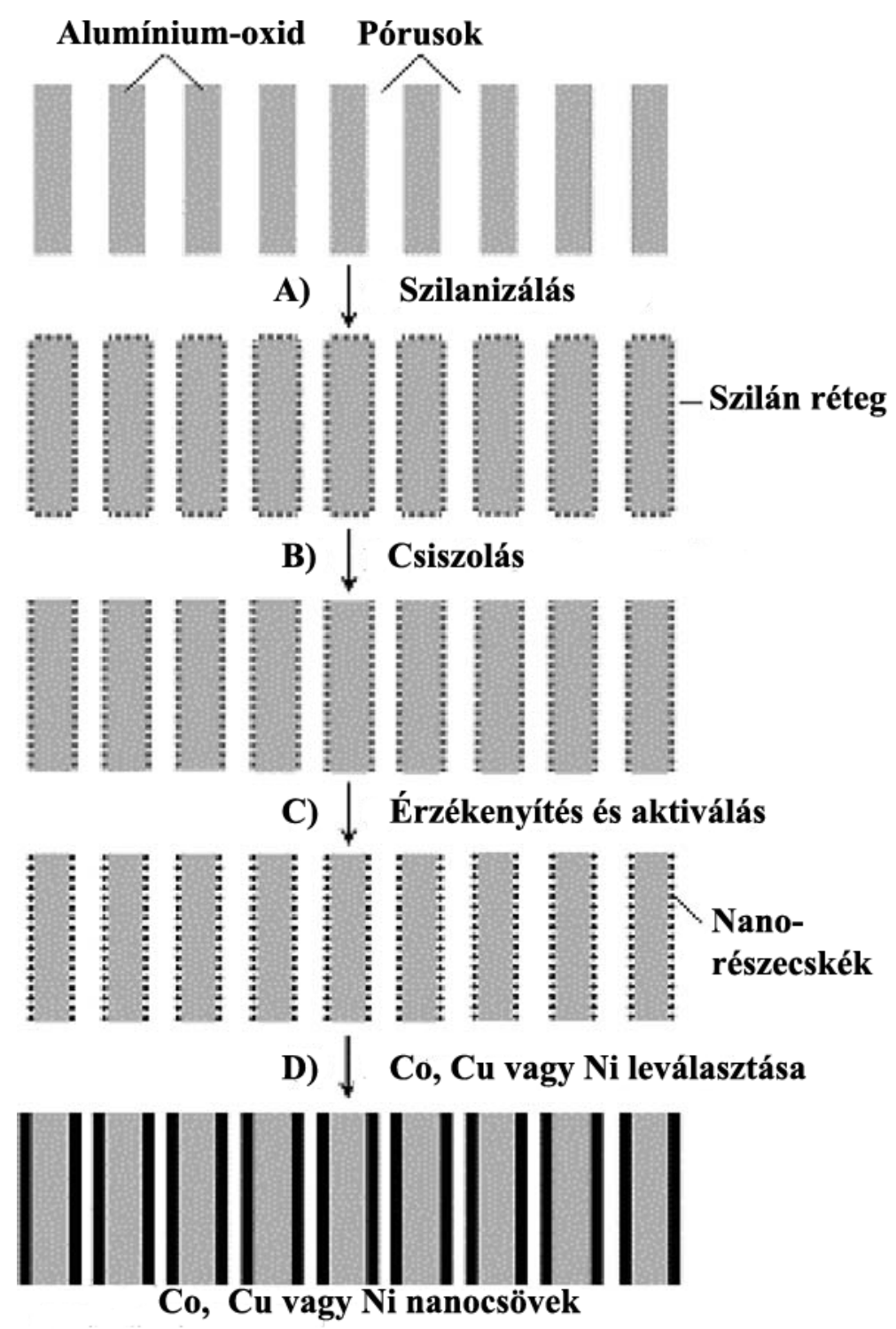

2.12. ábra: Anódos alumínium-oxid templátban kémiai redukcióval előállított nanocsövek ${ }^{137}$ előállításának lépései.

\subsubsection{Hidrotermális előállítási módszerek}

Feltehetően a hidrotermális eljárások a legalkalmasabbak fém nanoszálak nagy mennyiségben történő előállítására. Liu és munkatársai elsőként állítottak elő kb. 10 mikrométer hosszúságú réz nanoszálakat hidrotermális módszerrel $120^{\circ} \mathrm{C}$-on, $\mathrm{Cu}(\mathrm{II})$-glicerin komplexet használva, foszfit $\left(\mathrm{HPO}_{3}{ }^{2-}\right)$ és SDBS (nátrium-dodecil-benzol-szulfonát) jelenlétében. A folyamatban az SDBS mint védőmolekula funkcionál ${ }^{122}$. A réz nanoszálak valószínüleg az Ostwald-féle érés során alakulnak ki, azaz a folyamat első szakaszában 
képződő nanorészecskék fokozatos feloldódásával szabad $\mathrm{Cu}$-atomok vándorolnak a nagy felületi szabadenergiával rendelkező nagyobb kristályok felületére.

Néhány évvel később Zheng viszonylag alacsony hőmérsékletü hidrotermális módszerrel pórusos, négyszögletes keresztmetszettel rendelkező réz nanoszálakat előállítását mutatta be, amelyhez aszkorbinsavat és polivinil-pirrolidont használt ${ }^{139,140}$. A folyamatot alacsony hőmérsékleten $\left(120^{\circ} \mathrm{C}\right)$ végezték. Feltételezéseik szerint a nanoszálak a korai szakaszban kialakuló nanorészecskékből alakulnak ki az Ostwald-féle érés révén.

Wang ultrahosszú nanoszálakat állított elö, amelyhez redukálószerként aszkorbinsavat használt. A nanoszálak $160{ }^{\circ} \mathrm{C}$-on 6 óra alatt alakultak ki. A pásztázó elektronmikroszkópos felvételek alapján kimutatták, hogy a nanoszálak kis, szubmikrométeres részecskékből formálódnak szubmikrométeres nanoszálakká az idő függvényében. A feltételezett kialakulási folyamat lépései: a nukleáció $\rightarrow$ agglomeráció $\rightarrow$ anizotrópikus növekedés $\rightarrow$ átkristályosodás ${ }^{141}$.

Shi oktadecil-amint alkalmazva sikeresen állított elő nagy hossz/átmérő aránnyal rendelkező réz nanoszálakat. A hozzáadott védőmolekula ebben az esetben redukálószerként is funkcionál. A határolt területü diffrakciós (SAED) mintázatok alapján kimutatták, hogy a nanoszálak kristályossága erősen függ a szintézis hőmérsékletétől. Alacsonyabb hőmérsékleten $\left(120^{\circ} \mathrm{C}\right)$ polikristályos nanoszálak alakulnak ki, míg $180{ }^{\circ} \mathrm{C}$-on egykristályos nanoszálak képződnek ${ }^{142}$.

Deng és kollégái egy egyszerű hidrotermális módszert dolgoztak ki szénréteggel burkolt réz "nanokábelek" (copper-core/carbon-sheath) előállítására. Ezek a szénbe csomagolt réz nanoszálak egy komplex hidrotermális redukciós/karbonizációs lépés során CTAB és HMT (hexametilén-tetramin) jelenlétében állíthatók elő. A CTAB kulcsszerepet játszik a szerkezet kialakulásában, a HMT pedig a redukálószer a reakcióban ${ }^{143}$.

Koreai kutatók CTAB/amin/víz/ciklohexán rendszerben réz-amin komplex segítségével sikeresen állítottak elő $50 \mu \mathrm{m}$ hosszú 200-1000 nm átmérővel rendelkező réz nanoszálakat ${ }^{144}$.

\subsubsection{Réz nanoszálak elektromos tulajdonságai}

Annak ellenére, hogy számos publikáció utal a hidrotermális úton előállított réz nanoszálak elektromos tulajdonságainak kihasználhatóságára, az irodalom e területe meglehetősen hiányos. Mostanáig szinte kizárólag az elektrokémiai eljárással előállított réz nanoszálak áram-feszültség (I-V) karakterisztikájának ${ }^{121,145}$ meghatározására történtek kísérletek és mérések. 
Trautmann és kollégái polikarbonátmembránban növesztett egykristályos és polikristályos minták elektromos tulajdonságait vizsgálták 4,2 K-en és szobahőmérsékleten ${ }^{121}$. Szobahőmérsékleten és 4,2 K-en is lineáris karakterisztikát, illetve $145 \Omega$-os és 94,6 $\Omega$-os ellenállást határoztak meg. A nanoszál I-V görbéjét oxidatív atmoszférában 12 órán keresztül mérték. A szál ellenállása a kezdeti értékről hat nagyságrenddel növekedett ez időszak alatt. A réz nanoszál meglehetősen nagy felület/térfogat arányának köszönhetően igen érzékeny az oxigén jelenlétére. Az oxigén hatására a réz nanoszál p-típusú $\mathrm{Cu}_{2} \mathrm{O}$ félvezetővé alakul át.

A réz nanoszerkezetek esetében komoly problémát okoz az oxigénre való nagyfokú érzékenység. Feltételezhetően ez az oka annak, hogy még az anyag technológiai jelentőségének ellenére sem túl népszerűek a réz nanoszerkezetek előállítására vonatkozó oldatreakciók. 


\subsection{GALVANIKUS FÉMCSERE HELYETTESÍTÉSI REAKCIÓ}

A korróziót gyakran úgy definiálják, mint a fémet roncsoló környezeti hatást, amely különböző formákat, így réseket és üregeket mar a fémbe ${ }^{146}$. Bár a korrózió általában egy nemkívánatos jelenség, mégis sokoldalúan felhasználható pórusos szerkezetek, például fém membránok készítésére ${ }^{147}$. Noha számos folyadék fázisú módszer áll rendelkezésünkre meghatározott morfológiai tulajdonságokkal rendelkező nanorészecskék előállítására ${ }^{148-150}$, az üreges nanoszerkezetek előállítása még napjainkban is kiemelkedő kihívásnak számít.

A galvanikus fémcsere helyettesítési reakció egy igen egyszerü és hatékony módszer fém nanoszerkezetek előállítására. A reakció hajtóereje a két fém közti potenciál különbségen alapul, amelyben az egyik fém, úgy viselkedik, mint egy katód, míg a másik anódként funkcionál. Így például, ha egy darab $\mathrm{Zn}$ lemezt $\mathrm{Cu}^{2+}$ ionokat tartalmazó oldatba merítünk, akkor elemi réz kiválást és a $\mathrm{Zn}$ oldódását figyelhetjük meg. Mivel a $\mathrm{Cu}^{2+} / \mathrm{Cu}$ elektród standard elektród potenciálja $(0,34 \mathrm{~V})$ nagyobb ezért oxidálni fogja a kisebb standard elektród potenciállal $(-0,76 \mathrm{~V})$ rendelkező fémet, a Zn-et. Amennyiben egy fém nanoszerkezetet nála nagyobb standard elektród potenciállal rendelkező nemesfém ionokat tartalmazó oldatba teszünk, a fent említett reakció révén nemesfém nanoszerkezetet tudunk elóállítani. Ezáltal a módszer alkalmas nagy fajlagos felülettel rendelkező pórusos fém nanoszerkezetek kialakítására, melyek számos alkalmazás építőelemeivé válhatnak.

Habár jelentős számú módszert dolgoztak ki félvezető nanoszálak előállítására ${ }^{36}$, ezzel szemben csak néhány eljárás született fém nanoszálak előállítására. A galvanikus fémcsere helyettesítési reakció egy olyan egyszerű kémiai reakció, amelyben a templátként alkalmazott nanoszálak kettős funkciót (templát és redukálószer) töltenek be, amely megoldást kínál a fém nanoszálak előállítási problémájára.

\subsubsection{Nemesfém nanoszerkezetek előállítása fémcsere helyettesítési reakcióval}

Maga az eljárás nem újkeletü, azonban a nanoszerkezetekre történő alkalmazása csak az elmúlt években kezdődött. A módszert elég körültekintően kidolgoztákva ezüst nanoszerkezetek aranyra történő cseréjére ${ }^{44,151-158}$. Ehhez hasonlóan az Ag/Pt és Ag/Pd csere is elég intenzíven kutatott terület ${ }^{159-162}$. Az ezüst nanoszerkezeteket általában többértékü alkoholok jelenlétében az ún. poliol módszerrel állítják elő ${ }^{108,163,164}$.

A redoxi reakciót nanoszerkezetekre feltehetően Yang és munkatársai alkalmazták elsőként, amikor $\mathrm{LiMo}_{3} \mathrm{Se}_{3}$ nanoszálak segítségével $\mathrm{Au}, \mathrm{Ag}$ és Pt nanoszálakat állítottak elö ${ }^{165}$. Ehhez hasonlóan Xia és munkatársai $\mathrm{Au}, \mathrm{Pd}$ és Pt nanocsöveket állítottak elő ezüst 
nanoszálak és a fémek megfelelő ionjait tartalmazó vizes rendszerben ${ }^{91,166}$. A módszer elve az, hogy az ezüst nanoszálak a $\mathrm{HAuCl}_{4}$ vizes oldatával érintkezve ezüstionná oxidálódnak. $\mathrm{Az}$ atomok oxidációja egy tühegynyi lyuk képződéséhez vezet a nanoszál felszínén. A redoxi reakció eredményeképpen a nanoszál környezetében $\mathrm{Au}^{0}$ atomok képződnek, amelyek, miután mennyiségük egy kritikus értéket meghalad, a nanoszál felületén lerakódnak és további kiválással egy összefüggő burkot alkotnak. A reakció a legnagyobb energiával rendelkező kristálylapokon kezdődik és halad a kisebb energiájúak felé. A folyamat kezdeti fázisában a burok még hézagos, így a hézagokon keresztül biztosított mindkét reaktáns diffúziója, míg az ezüst templát teljesen fel nem emésztődik. Amennyiben a magas hőmérsékleten végezett fémcsere helyettesítési reakciót visszafolyatás követte, az Ostwald-féle érés révén a nanocsövek fala átkristályosodott és egykristályos fém nanocsöveket képződtek. Ugyanakkor az átkristályosodás eltüntette a pórusokat és a nanocsövek falának felszíne kisimult ${ }^{166}$. A folyamat sematikus rajzát és a keletkezett nanocsöveket a 2.13. ábra mutatja be.
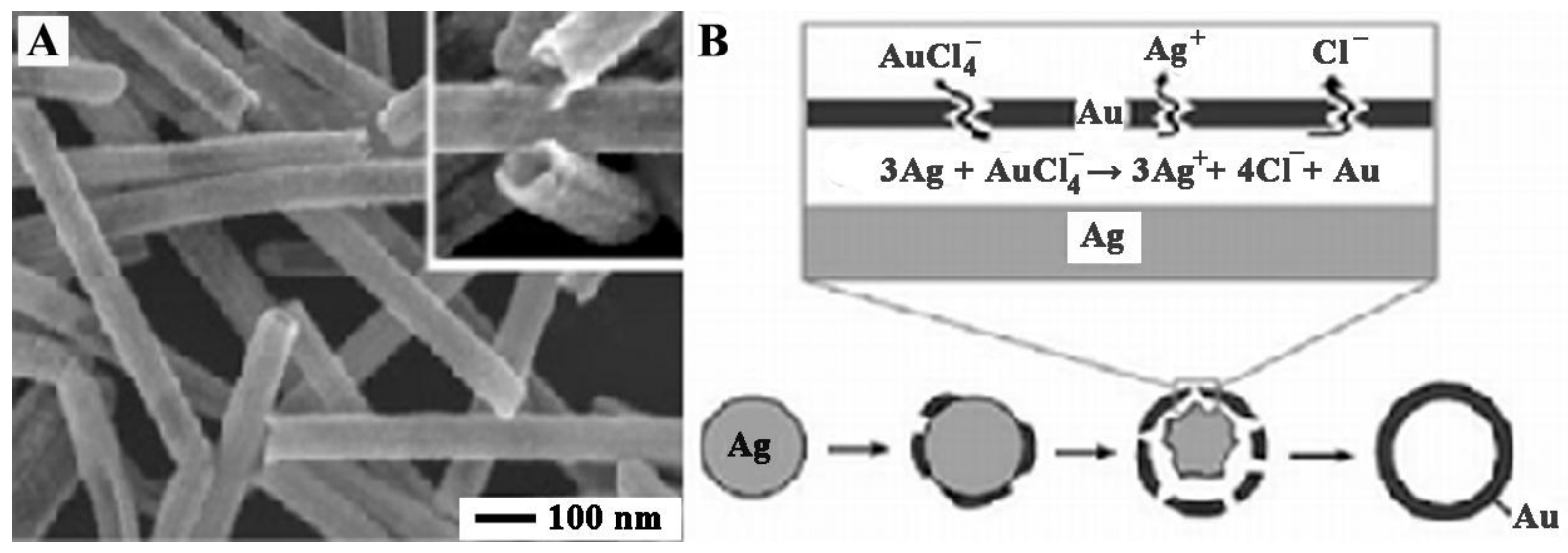

2.13. ábra: (A) Pd nanocsövek és (B) fémcsere helyettesítési reakció sematikus ábrája ${ }^{166}$.

A 2.14. ábra Xia és munkatársai ezüst nanokockákon végzett arannyal történő fémcsere helyettesítési reakciójának egyes lépéseit mutatja be ${ }^{167}$. Az $\mathrm{Ag} / \mathrm{Au}$ fémcsere esetében az aranyatomok előszeretettel válnak ki az ezüst nanoszerkezet felszínén, mivel a két fém ugyanolyan fcc kristályrácsszerkezettel rendelkezik, sőt rácsállandójuk is csak kissé tér el egymástól. A tühegynyi lyukak kialakulását követően, az ezüst a nanokockák belső részéből lép ki. A hőmérséklet emelésével a nanokockák falát átmenetileg az arany és az ezüst ötvözete alkotja $^{168}$. További Au adagolására a nanoszerkezet falából az ezüst szelektíven lép ki ${ }^{169}$. A reakció sztöchiometriai egyenlete szerint egy Au-atom kiválásához három Ag-atom oxidációjára van szükség, ezért ebben az állapotban jelentős mennyiségü rácshiba jön létre. Ez a határfelület és a felületi energia növekedését eredményezi ${ }^{170}$. A rácshibák 
kiküszöbölésére az Ostwald-féle éréshez hasonló módon a nanoszerkezet morfológiája átrendeződik $^{171}$. Eredményül a kockák csúcsai eltűnnek és $\{111\}$ kristálylapokkal határolt forma jön létre. Az ezüstatomok további eltávolítása újabb rácshibák keletkezését, azok összeolvadásával újabb lyukak kialakulását vonja maga után. Az ezüst teljes „,kioldása” ketrec jellegü szerkezetet, majd a szerkezet összeomlását eredményezi.

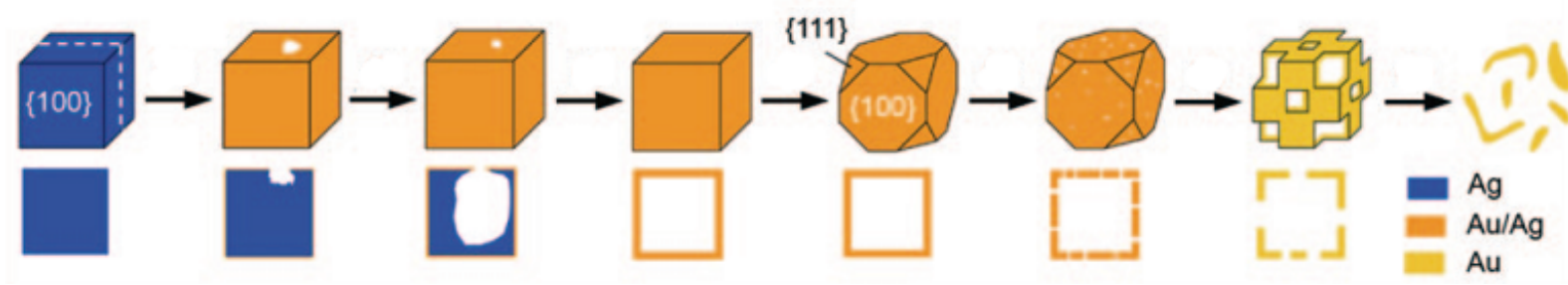

2.14. ábra: Pórusos Au-szerkezet kialakulásának legfontosabb morfológiai és szerkezeti állomásai ${ }^{167}$.

Természetesen a folyamat egyéb fémekre is müködik, melyek elektródpotenciálja nagyobb, mint az $\mathrm{Ag}^{+} / \mathrm{Ag}(0,80 \mathrm{eV}$ SHE-hoz képest) páré. A standard elektród potenciál a $\mathrm{Pt}^{2+} / \mathrm{Pt}(1,2 \mathrm{~V}) \mathrm{Pd}^{2+} / \mathrm{Pd}(0,83 \mathrm{~V})$ pár esetében lehetővé teszi Pt, Pd és ötvözet nanoszerkezetek elöállítását. Xia és munkatársai ezüst nanokockák és $\mathrm{Na}_{2} \mathrm{PtCl}_{4}$, illetve $\mathrm{Na}_{2} \mathrm{PdCl}_{4}$ között is elvégezték a galvanikus fémcsere helyettesítési reakciót ${ }^{162}$. Az eljárás során eltérő viselkedést fedeztek fel az $\mathrm{Ag} / \mathrm{Pd}$ fémcsere reakció esetében. A falak $\mathrm{Pd} / \mathrm{Ag}$ aránya 0,69 értéket elérve további $\mathrm{Na}_{2} \mathrm{PdCl}_{4}$ adagolásra nem változott meg. A nanoszerkezet felületén gyorsan kialakul az ezüst-palládium ötvözet, amely ellenáll a galvanikus fémcsere elektrokémiai hajtóerejének. Ezzel szemben a platina fémcsere reakció során a nanokockák falát Pt nanorészecskék alkotják. Az eltérés oka, hogy szemben az $\mathrm{Au} / \mathrm{Ag}$ és a $\mathrm{Pd} / \mathrm{Ag}$ rendszerrel a platina esetében nem megy végbe szilárd fázisú interdiffúzió ( $900 \mathrm{~K}$ alatt), amely révén a két fém ötvözete létrejön.

Az ezüst templátok mellett egyéb, fóként átmenetifém templátok használatára is van néhány példa. Bai és munkatársai üreges $\mathrm{Pt}$ nanorészecskéket állítottak elő $\mathrm{H}_{2} \mathrm{PtCl}_{4}$ és kobalt nanorészecskék közt végzett galvanikus fémcsere helyettesítési reakcióval ${ }^{172}$. A módszert később kifejlesztették üreges Au és Pd nanorészecskék előállítására is. Üreges Co-Pt ötvözet nanorészecskék előállítását dolgozta ki Schaak kutatócsoportja. A kobalt-klorid oldatához $\mathrm{NaBH}_{4}$-oldatot adva kobalt nanorészecskéket állítottak elö. A folyamatban PVP-t alkalmaztak védőmolekulaként. Ezt követően $\mathrm{K}_{2} \mathrm{PtCl}_{6}$-oldatot adagoltak a kobalt nanorészecskék oldatához. A visszamaradó $\mathrm{BH}_{4}{ }^{-}$-t redukálja a galvanikus fémcsere helyettesítési reakció során keletkező $\mathrm{Co}^{2+}$-ionokat. A PVP-ről tudott, hogy megköti a kationokat ${ }^{173}$, így lehetővé 
válik a $\mathrm{Pt}^{4+}$ - és $\mathrm{Co}^{2+}$-ionok együttes redukciója, amely egy Co-Pt ötvözethéj kialakulásához vezet.

A galvanikus fémcsere helyettesítési reakció lehetővé teszi nemesfém nanoszerkezetek változatos összetételben, méretben és alakban történő előállítását, így ezek a szerkezetek számos alkalmazásban hasznosak lehetnek. Pórusos érdes felszínü szerkezetek, nagy fajlagos felületüknek köszönhetően katalitikus folyamatokban és szenzorokban használhatóak. Ugyanakkor ez idáig a leginkább tanulmányozott felhasználási terület az optikai alkalmazások területén valósult meg. Az eljárás lehetővé teszi a nanoszerkezetek felületi plazmonrezonanciájának (SPR) alakíthatóságát, amely felhasználható az optikai koherencia tomográfiai (OCT) képalkotásban és a fototermális rákkutatásban is ${ }^{167}$.

\subsubsection{Fémcsere helyettesítéssel előállított nanoszálak a katalízisben}

Bi és Lu kínai kutatók Pt nanorostokat (nanofibers) és nanocsöveket állítottak elö, Ag nanoszálakat alkalmazva templátként, a fent említett galvanikus fémcsere helyettesítési reakcióval $^{160}$. Módszerükben kulcsfontosságúnak tartották a CTAB jelenlétét, amely a Pt prekurzor redukciójának kontrolálásával a növekedési sebességet is befolyásolja. A Pt nanoszerkezetek elektrokatalitikus aktivitását a metanol elektrooxidációjában vizsgálták. Mind a nanocsövek, mind a nanorostok, valamint ezek „ötvözetei” is katalitikusan aktívnak bizonyultak a metanol oxidációban. A CV (áramsürüség-feszültség) görbék alapján a Pt nanocsövek mutatták a legnagyobb aktivitást és a nanorostok a legkisebbet. Ez feltételezhetően a nagy fajlagos felület és az egyedi kristályszerkezet következménye.

A Kaliforniai Egyetem kutatói Pt és PtPd ötvözet nanocsöveket (NTs) állítottak elő, amelyeket az oxigén redukciós reakciójában során teszteltek ${ }^{159}$. A katódon végbemenő oxigén redukció kulcsfontosságú reakció a protoncsere membrán üzemanyagcelláiban. Jelenleg katódként amorf szén aggregátumokra felvitt 2-5 nm-es $\mathrm{Pt}$ nanorészecskéket $(\mathrm{Pt} / \mathrm{C})$ alkalmaznak, melynek élettartama nem elegendően hosszú. Az élettartam csökkenés feltételezhetően a katalizátor elektrokémiai felületének csökkenése miatt következik be ${ }^{174-176}$. Ez a csökkenés négy dologra vezethető vissza: (1) a szén hordozó korróziója, (2) a platina feloldódása és kiválása, illetve Ostwald-féle érési folyamatok lejátszódása, (3) a felületi energia csökkentése érdekében a Pt nanorészecskék közt bekövetkező aggregáció és (4) a kioldódó $\mathrm{Pt}^{2+}$-ionok migrációja, valamint redukciója a membránon áthaladó hidrogén hatására. Ezeket a problémákat Yan és munkatársai nem hordozós Pt és PtPd ötvözet nanocsövekkel próbálták kiküszöbölni. A katalizátorok élettartamát ciklikus voltametriai 
mérésekkel jellemezték. Kísérleteik szerint 1000 ciklust követően a Pt szálak csak $20 \%$ felületcsökkenést mutattak, míg Pt-black por és Pt/C esetében a csökkenés 51 és $90 \%$ volt.

A galvanikus fémcsere helyettesítéssel előállított nanocsövek megoldást jelenthetnek a PEMFCs problémáira. 2010 végén Yang és Xia réz nanoszálak felhasználásával előállított Pt nanocsövek, a hangyasav oxidációjában mutatott elektrokatalitikus aktivitását vizsgálták. A Pt nanocsövek 10-12 \% rezet tartalmaztak. Vizsgálataik fényt derítettek arra, hogy a hangyasav oxidálásában a Pt nanocsövek mind élettartam, mind katalitikus aktivitás tekintetében felülmúlják a kereskedelmi forgalomban beszerezhető $\mathrm{Pt} / \mathrm{C}$-elektrokatalizátorokat ${ }^{177}$. A nanocsövek felületén lévő mezopórusok elősegítik a diffúziót és nagyobb felületet biztosítanak. A nanocsövek esetében a reakció a direkt, intermedierek kialakulása nélküli oxidáció felé tolódott el. 


\subsection{ETILÉN HIDROGÉNEZÉSE}

Egy katalizátor teszteléséhez célszerü egy olyan jól követhető tesztreakció kiválasztása, melyben egymástól jól elkülöníthető és könnyen detektálható termékek keletkeznek. Az etilén hidrogénezés során a $\mathrm{C}-\mathrm{H}$ kötés aktiválása könnyen vizsgálható, ezért ez a modellreakció igencsak elterjedt. A C-H kötés aktiválása a szerves molekulák katalitikus átalakításának és a hidrogén könnyű alkánokból történő előállításának központi feladata.

Az elmúlt 50 évben a jelentős technikai fejlődés révén lehetővé vált ultranagy vákuumban a szilárd-gáz határfelületek molekuláris szinten történő vizsgálata. Ezek a módszerek lehetővé tették a határfelületek szerkezetének és összetételének meghatározását. A monomolekuláris rétegben az atomok és molekulák felületi kötéseinek vizsgálata spektroszkópiai módszerekkel valósulhatott meg $^{178}$.

Napjainkra az etilén molekula adszorpciójának mechanizmusa igen részletesen ismert. A szénhidrogének hidrogénezése során bekövetkező hidrogénatom-vándorlást elsőként I. Horiuti és M. Polányi írták le (2.15. ábra $)^{179}$. Az 1930-as években a legegyszerübb olefin, az etilén hidrogénnel való telítésére, platinafelületen az első reakciómechanizmust ők javasolták. Vizsgálataik szerint az etilén kettőskötésének felszakadásával, két $\sigma$-kötéssel adszorbeálódik a platina felszínén. Ezt követően ez az intermedier 2 lépésben egy etil intermedieren keresztül telítődik etánná.
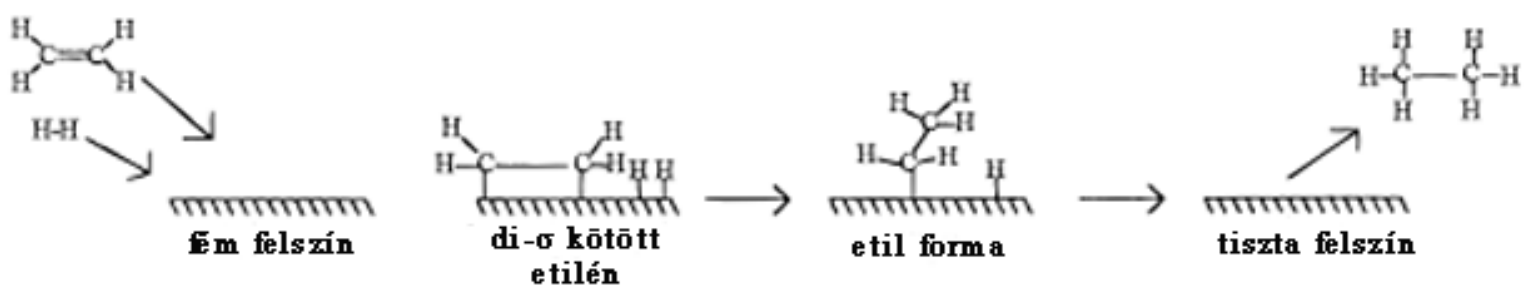

2.15. ábra: Horiuti-Polányi mechanizmus platinafelületen történő etilén hidrogéneződésre ${ }^{180}$.

Az etilén hidrogénezésének felületkémiai vizsgálata az 1970-es években kezdődött, amikor az alacsony Miller indexü felületeken adszorbeálódott etilént ultranagy vákuumban vizsgálták. Az etilén Pt(111)-felszínen bekövetkező adszorpcióját sokféle technikával tanulmányozták, és kimutatták, hogy számos felületi szpéciesz alakul ki a folyamat során.

Az ultraibolya fotoemissziós spektroszkópiai vizsgálatok kimutatták, hogy alacsony hőmérsékleten (52 K-en alatt) az etilén molekulárisan fiziszorbeálódik a $\operatorname{Pt}(111)$ - felületen, egy úgynevezett $\pi$-kötött etilén (2.16. ábra) felületi egységet kialakítva ${ }^{181}$. A hőmérséklet emelése a $\pi$-kötés irreverzibilis felhasadásához és két $\sigma$-kötés kialakulásához vezet. SFG (sum 
frequency generation) vibrációs spektrumok alapján megállapították, hogy $200 \mathrm{~K}$-en és $<10^{-6}$ Torr nyomáson az etilén molekula di-б-kötéssel kapcsolódik (2.16. ábra) a Pt(111)felszínhez ${ }^{182}$. A hőmérséklet további emelésével $250 \mathrm{~K}$-en etilidén $\left(\mathrm{HC}-\mathrm{CH}_{3}\right)$ szpéciesz alakul ki (2.16. ábra) molekulán belüli hidrogéntranszfer révén ${ }^{183}$.

Szobahőmérsékleten egy H-atom elvesztésével stabil etilidin $\left(\mathrm{C}-\mathrm{CH}_{3}\right)$ képződik platina, palládium és ródium (111) kristálylapján kötődve, melyben a C-C kötés merőleges a felületre és a felülethez kötődő szénatom hármas koordinációban van jelen. A hőmérséklet emelésével az etilidin egészen $430 \mathrm{~K}$-ig stabilis marad, majd további dehidrogéneződés következik be. A C-C kötés felhasad és acetilid $\left(\mathrm{C}_{2} \mathrm{H}\right)$ és metilidin $(\mathrm{CH})$ szpécieszek képződnek egészen $800 \mathrm{~K}$ ig, ahol bekövetkezik a grafit kialakulása ${ }^{184,185}$.

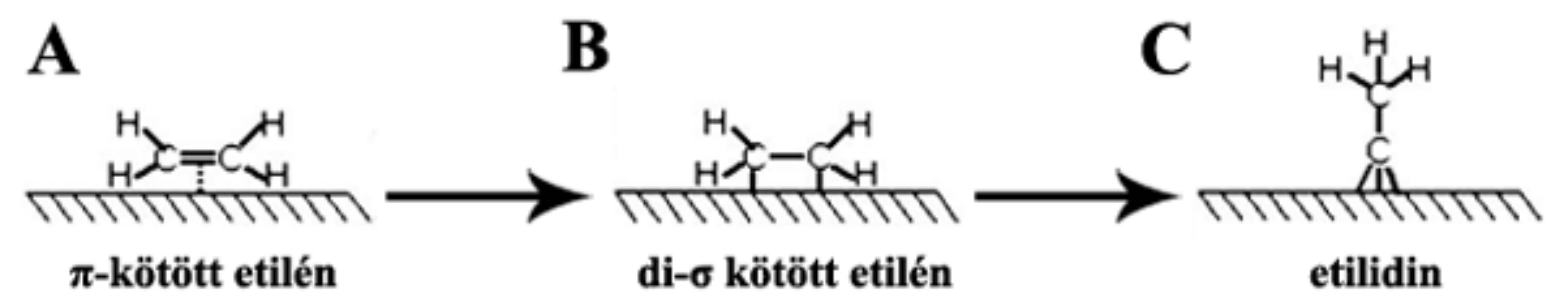

2.16. ábra: Pt(111)-felületen a hőmérséklet emelésével kialakuló szpecieszek: (A) $\pi$-kötött etilén alacsony hőmérsékleten, (B) di- $\sigma$-kötött etilén és (C) etilidin.

Felületkémiai vizsgálatok rámutattak arra, hogy az egyenetlen felszínü anyagok jobb katalizátorok, mint a sima felületek ${ }^{178}$. A nanotechnológia kutatások előrehaladásával egyre több méretfüggő tulajdonságra derül fény, amelyek segítenek megérteni a felületek szerepét a katalízitikus folyamatokban ${ }^{185}$. Így például kimutatták, hogy a fémklaszterek olvadási hőmérséklete méretfüggő ${ }^{186}$, a kisebb klaszterek nyomásindukált szerkezeti átalakulása könnyebben, kisebb aktiválási energiával megy végbe ${ }^{187}$. A nanokristályok tökéletesebbek, hiszen a kis méretük révén a diszlokációk nem jellemzőek ${ }^{186}$. Ugyanakkor az elektromos tulajdonságokban is hasonlóan érdekes változások következnek be. Az érdes felszínnel rendelkező klaszterek esetében felerősített Raman-szórást észlelhetünk ${ }^{156}$. Ezek és az ezekhez hasonló feltárásra váró tulajdonságok egyedülálló lehetőségeket kínálnak a felületi jelenségeket kihasználó alkalmazásokban (katalízis, mikroelektronika stb.). 


\section{CÉLKITÜZÉS}

A nanoszerkezetü anyagokhoz kapcsolódó nanotechnológiai kutatások talán egyik legnagyobb kihívása a szervetlen nanokristályok morfológiájának kontrolálása, mivel a fémekre, félvezetőkre és az oxidokra egyaránt igaz az, hogy nanokristályaik morfológiája befolyásolja fizikai tulajdonságaikat. Ezt kihasználva új elektromos, optikai és mágneses tulajdonságokkal rendelkező anyagok előállítása vált lehetővé, ami új területet nyitott az alapkutatásban és a technológiai fejlődésben.

Az elmúlt években az Alkalmazott és Környezeti Kémiai Tanszéken többféle anyagból sikeresen állítottak elő egydimenziós (1D) nanoszerkezeteket. Vizsgálták a szén és titanát nanocsövek és nanoszálak tulajdonságait és alkalmazási lehetőségeit. Ehhez kapcsolódva, doktori munkám céljául az 1D fém nanoszerkezetek előállítását, morfológiájuk és felhasználhatóságuk lehetőségeinek vizsgálatát, valamint a galvanikus fémcsere helyettesítési reakció 1D nanoszerkezeteken történő alkalmazásának tanulmányozását tüztük ki.

Munkám kezdeti szakasza pórusos szerkezetü, nagy fajlagos felületü 1D nanoszerkezetek előállítására irányult, mely célra a szakirodalomban publikált galvanikus fémcsere helyettesítési reakciót találtuk a legalkalmasabbnak. Fontosnak tartottuk,

- hogy az általában templátként használt ezüst nanoszerkezet helyett valami olcsóbban és könnyen elöállítható anyagot keressünk, mivel a folyamat során a templát anyaga szinte teljes mértékben elhasználódik;

- hogy, az előállított pórusos nanoszálakat anyagvizsgálati módszerekkel (SEM, EDS, XRD, $\mathrm{N}_{2}$ adszorpció stb.) jellemezzük, ami elengedhetetlen a képződési mechanizmusuk és alkalmazási lehetőségeik felderítéséhez;

- hogy az előállított pórusos nanoszálak katalitikus aktivitását egy ismert tesztreakcióban megvizsgáljuk.

Munkám második szakaszában 1D réz nanoszerkezeteket állítottunk elő az alábbi célokkal:

- viszonylag nagy mennyiségü réz nanoszál elöállitására alkalmas eljárás kifejlesztése;

- egykristályos, nagy hossz/átmérő aránnyal rendelkező nanoszálak előállítása. 
Megkíséreltük feltérképezni a réz nanoszálak kialakulási mechanizmusát az alábbi szempontoknak megfelelően:

- a nanoszálak kialakulásának TEM, ED, SEM, EDS, XRD stb. vizsgálati eszközökkel történő követése a szintézisidő függvényében;

- $\quad$ az egyes reaktánsok szerepének tisztázása a nanoszálak kialakulásában;

- $\quad$ az egyéb morfológiák és nanoszál megjelenési formák közötti kapcsolat feltárása;

- az alkalmazott kiindulási rézsó $\left(\mathrm{CuCl}_{2}, \mathrm{Cu}\left(\mathrm{CH}_{3} \mathrm{COO}\right)_{2}, \mathrm{Cu}\left(\mathrm{NO}_{3}\right)_{2}\right)$ hatásának megismerése a hidrotermális módszerrel gyártott nanoszálak fizikai-kémiai és morfológiai megjelenésére;

- a kiindulási oldathoz adott sók ( $\mathrm{NaCl}, \mathrm{NaBr}$ stb.) hatásának felderítése a réz nanoszerkezetek morfológiájára;

- a réz nanoszálak elektromos tulajdonságainak jellemzése.

Végül az utolsó szakaszban a Pt és Pd nanocsövek előállítását tüztük ki célul a réz nanoszálakon végzett galvanikus fémhelyettesítési reakcióval. Terveink közt szerepelt:

- eltérő $\mathrm{Pt} / \mathrm{Cu}$ és $\mathrm{Pd} / \mathrm{Cu}$ mólarányok mellett elöállított nanocsövek kémiai összetételének vizsgálata

- $\quad$ az előállítási mechanizmusok feltárása. 


\section{KÍSÉRLETI RÉSZ}

\subsection{A KÍSÉRLETI MUNKA SORÁN FELHASZNÁLT ANYAGOK}

Nikkel nanoszálak elóállításához felhasznált anyagok:

Nikkel(II)-szulfát $\left(\mathrm{NiSO}_{4}\right)$ - Fisher

Bórsav $\left(\mathrm{H}_{3} \mathrm{BO}_{3}\right)$ - Sigma-Aldrich

Nátrium-hidroxid $(\mathrm{NaOH})$ - Sigma-Aldrich

Whatman Anodisc 25, alumínium-oxid templát $25 \mathrm{~mm}, 60 \mu \mathrm{m}$ mély és $0,2 \mu \mathrm{m}$ átméröjü pórusokkal

Whatman Anodisc 13, alumínium-oxid templát $13 \mathrm{~mm}, 60 \mu \mathrm{m}$ mély és $0,2 \mu \mathrm{m}$ átmérőjü pórusokkal

Ezüst drót 2 mm-es ármérővel - SPI Supplies

Salétromsav $\left(\mathrm{HNO}_{3}\right)$ - Sigma-Aldrich

\section{Pórusos nanoszálak elöállításáshoz felhasznált anyagok:}

Nátrium-bórhidrid $\left(\mathrm{NaBH}_{4}\right)$ - Sigma-Aldrich

Hidrazin monohidrát $\left(\mathrm{N}_{2} \mathrm{H}_{2} \cdot \mathrm{H}_{2} \mathrm{O}\right)$ - Sigma-Aldrich

Hidrogén-[tetrakloro-aurát] $\left(\mathrm{HAuCl}_{4}\right)$ - Sigma-Aldrich

Kálium-[hexakloro-platinát(IV)] $\left(\mathrm{K}_{2} \mathrm{PtCl}_{6}\right)$ - Sigma-Aldrich

Kálium-[tetrakloro-palladát(II)] $\left(\mathrm{K}_{2} \mathrm{PdCl}_{4}\right)$ - Sigma-Aldrich

\section{Réz nanoszálak elöállitásához felhasznált anyagok:}

Réz(II)-klorid $\left(\mathrm{CuCl}_{2} \cdot 2 \mathrm{H}_{2} \mathrm{O}\right)-$ Reanal

Réz(II)-acetát $\left(\mathrm{Cu}\left(\mathrm{CH}_{3} \mathrm{COO}\right)_{2} \cdot \mathrm{H}_{2} \mathrm{O}\right)-$ Sigma-Aldrich

Réz(II)-nitrát $\left(\mathrm{Cu}\left(\mathrm{NO}_{3}\right)_{2} \cdot 2,5 \mathrm{H}_{2} \mathrm{O}\right)$ - Sigma-Aldrich

D-glükóz $\left(\mathrm{C}_{6} \mathrm{H}_{12} \mathrm{O}_{6}\right)$ - Reanal

Nátrium-klorid $(\mathrm{NaCl})$ - Reanal

Nátrium-bromid ( $\mathrm{NaBr})$ - Reanal

1-Hexadecil-amin $\left(\mathrm{CH}_{3}-\left[\mathrm{CH}_{2}\right]_{15}-\mathrm{NH}_{2}\right)$ - Sigma-Aldrich

Abszolút etanol $\left(\mathrm{C}_{2} \mathrm{H}_{5} \mathrm{OH}\right)-$ Molar

n-Hexán $\left(\mathrm{CH}_{3}-\left[\mathrm{CH}_{2}\right]_{4}-\mathrm{CH}_{3}\right)$ - Sigma-Aldrich 


\section{Stober szilika elöállításáhozfelhasznált anyagok}

Tetraetoxi-szilán (TEOS) $\left(\mathrm{C}_{8} \mathrm{H}_{20} \mathrm{SiO}_{4}\right)$ - Fluka

Ammónium-hidroxid $\left(\mathrm{NH}_{4} \mathrm{OH}\right)$ - Molar

Abszolút etanol $\left(\mathrm{C}_{2} \mathrm{H}_{5} \mathrm{OH}\right)-$ Molar

\section{Katalitikus mérések során használt gázok}

Hidrogén (99,5\%, Messer)

Etilén $(99,5 \%$, Messer)

Nitrogén $(99,95 \%$, Messer)

Oxigén $(99,5 \%$, Messer)

\subsection{VIZSGÁLATI MÓDSZEREK}

A szintetizált anyagokat sokféle fizikai és kémiai módszerekkel vizsgáltuk.

\subsubsection{Elektronmikroszkópia (TEM, SEM)}

A nanoméretü anyagok jellemzésének elengedhetetlen vizsgálati módszere az elektronmikroszkópia, hiszen lehetővé teszi az előállított anyagok morfológiájának, kristályszerkezetének és kémiai összetételének tanulmányozását.

\section{Transzmissziós elektronmikroszkópia (TEM)}

A transzmissziós elektronmikroszkópia igen nagy felbontást biztosít, így alkalmas a nanoméretü anyagok tanulmányozására. A nanoszálak méreteit, morfológiáját és szerkezetét Philips CM10 típusú elektronmikroszkóppal vizsgáltuk 100 kV-os gyorsító feszültséget alkalmazva. A minta etanolos szuszpenziójából egy cseppet vittünk fel réz rostélyra.

\section{Elektrondiffrakció (ED)}

Az elektrondiffrakció alkalmas a nanoszerkezetü anyagok kristályszerkezetének feltárására. A vizsgálatok alapján a minta kristályszerkezetéről pontosabb információkat nyerhetünk, amelyek fontosak lehetnek a felhasználás szempontjából. Meghatározhatjuk továbbá a rácsállandót is. Az elektrondiffrakciós vizsgálatokat szintén réz rostélyra felvitt mintákon végeztük. 


\section{Pásztázó elektronmikroszkópia (SEM)}

A pásztázó elektronmikroszkóp felbontóképessége általában ugyan kisebb, mint a transzmissziós elektronmikroszkópé, azonban ez a módszer lehetővé teszi a nanoszerkezetü anyagok felszínének vizsgálatát.

A nanoszálak morfológiáját egy FEI Quanta 400 ESEM FEG és egy Hitachi S-4700 pásztázó elektronmikroszkóppal vizsgáltuk. Ehhez alumínium mintatartóra kétoldalú szén ragasztószalaggal rögzített szilícium (111) lapra cseppentettünk a minta etanolos szuszpenziójából. A vizsgálatokat 5-30kV gyorsítófeszültség mellett végeztük.

\section{Energiadiszperzív spektroszkópia (EDS, EDAX)}

Ez a módszer a minta kémiai összetételéről ad információt. Az egyéb műszeres analitikai vizsgálatok mellett jelentősége abban rejlik, hogy megközelítőleg $1 \mu \mathrm{m}$ átmérőjü gömbtérfogat (,gerjesztési körte”) vizsgálatát teszi lehetővé. Ezzel a módszerrel lehetőség nyílik a minta meghatározott térrészeinek vizsgálatára, illetve az sem okoz gondot, ha az adott mintából kis mennyiség áll rendelkezésünkre.

Az energiadiszperzív analízishez a SEM mintákat használtuk fel. A vizsgálatokat $20 \mathrm{kV}$ gyorsítófeszültséggel végeztük.

\subsubsection{Röntgen diffraktometria (XRD)}

A nanoszálak anyagi minőségéről röntgen diffrakciós vizsgálatokkal győződtünk meg. Ehhez a minta etanolos szuszpenziójából a mintatartóra csepegtettük a mintát, majd ezt száradást követően addig ismételtük, míg egy jól látható bevonatot nem kaptunk. Méréseink során egy Rigaku D/Max Ultima II (Rice University) és egy Rigaku Miniflex II (SZTE) készülékekkel dolgoztunk, amelyek a $\operatorname{CuK} \alpha(\lambda=0,15418 \mathrm{~nm})$ sugárzásnak megfelelő hullámhosszat használnak. A méréseket $2 \theta=3-80^{\circ}$-os tartományban végeztük el. A kapott röntgen diffraktogramok értékelése során a JCPDS kártyák adatait hasonlítottuk össze a mérési eredményekkel.

\subsubsection{Röntgen fotoelektron spektroszkópia (XPS)}

A röntgen fotoelektron spektroszkópiai vizsgálatokat PHI Quantera XPA müszerrel végeztük. A méréshez az etanolos közegben szuszpendált mintákból 1-1 cseppet szilícium (111) lapra cseppentettünk fel. 


\subsubsection{Fajlagos felület meghatározása}

A fajlagos felületet nitrogén adszorpciós-deszorpciós méréssel, Quantachrome NOVA 2200 típusú gáz szorpciós analizátorral határoztuk meg, a -196 ${ }^{\circ} \mathrm{C}$-on $(77 \mathrm{~K}$-en) adszorbeált nitrogén mennyiségének mérésével. A fajlagos felületet a BET módszerrel az adszorpciós izoterma 0,1-0,3 relatív nyomáshoz tartozó értékeiből határoztuk meg.

\subsubsection{Katalitikus mérések}

A nanoszálak etilén hidrogénezésben mutatott katalitikus aktivitását az SZTE Alkalmazott és Környezeti Kémiai Tanszékén összeállított katalitikus rendszerben teszteltük. A vizsgálatokat egy Agilent 6820 típusú gázkromatográffal (GC) felszerelt állóágyas mikroreaktorban, folyamatos gázáramok mellett végeztük. A katalitikus rendszer nyomásbiztos Swagelok ${ }^{\circledR}$ elemekből lett összeállítva. A katalízis során alkalmazott gázok áramlási sebességét tömegáram szabályzók segítségével állítottuk be. A maximális bemeneti nyomás 5 bar $\left(5 \times 10^{5} \mathrm{~Pa}\right)$, a kimeneti oldalon pedig 1 bar $\left(10^{5} \mathrm{~Pa}\right)$ volt. Reaktorként „U” alakú üvegcsövet használtunk, amelyben egy üvegfritt szolgált a katalizátorágy megtartására. A cső belső átmérője a katalizátorágy magasságában $8 \mathrm{~mm}$. Az anyagkihordás megakadályozása érdekében üveggyapot tömítést alkalmaztunk a kimeneti oldalon. Ez a tömítés nem zavarta a gázok áramlását, azonban megakadályozta, hogy szennyező szemcsék kerüljenek a GC-be.

A kalibrált tömegáram szabályzókat közvetlenül a számítógépről tudtuk vezérelni. A gázkromatográf saját vezérlőprogrammal rendelkezett.

A gázkromatográfban egy GS-Gaspro típusú, $60 \mathrm{~m}$ hosszú, 0,32 mm átmérőjü, 0,25 $\mu \mathrm{m}$ vastagságú folyadékfilmmel rendelkező, 3710/m elméleti tányérszámú kolonna végezte a komponensek elválasztását. A kolonnatér hőmérséklete a kísérletek során $90{ }^{\circ} \mathrm{C}$ (363 K), míg a betáplálás hőmérséklete $200{ }^{\circ} \mathrm{C}(473 \mathrm{~K})$ volt. A detektáláshoz lángionizációs detektort alkalmaztunk, melynek hőmérséklete $300{ }^{\circ} \mathrm{C}(573 \mathrm{~K})$ volt. A mintavétel a reaktor kilépési pontján a gázútba épített 6-utas mintavevő csap segítségével történt megfelelő időközönként. A minta mennyisége $250 \mu 1$ volt. 


\subsubsection{Elektromos mérések}

Az elektromos mérésekhez a réz nanoszálakat etanolban szuszpendáltuk és egy Pt/Ti elektródokkal (15 $\mu$ m-es közök) ellátott $\quad \mathrm{Si} / \mathrm{SiO}_{2}$ lapkára csepegtettük. $\mathrm{Az}$ ellenállás-hőmérséklet, áramerősség-feszültség és az ellenállás-gate(kapu)-feszültség mérésekhez Keithley 2636A multimétert használtunk. Az áramerősség-hőmérséklet és az áramerősség-feszültség mérésekhez a $6 \mathrm{~K} /$ perc-es fütési és hütési sebességet Linkam THMS600 hüthető-füthető tárgyasztal alkalmazásával biztosítottuk. A mintákat 150-625 K $\left(-123-352^{\circ} \mathrm{C}\right)$ hőmérséklettartományban eltérö gázatmoszférákban $\left(\mathrm{N}_{2}\right.$, szintetikus levegö, $\mathrm{H}_{2} / \mathrm{Ar}$ ), 1 bar nyomáson vizsgáltuk. Az elektromos mérések során a réz nanoszálak $\mathrm{Cu}(\mathrm{I})_{2} \mathrm{O}-$ dá és $\mathrm{Cu}(\mathrm{II}) \mathrm{O}$-dá történő átalakulásait is vizsgáltuk. 


\section{EREDMÉNYEK ÉS ÉRTÉKELÉSÜK}

\subsection{NIKKEL NANORUDAK ELŐÁLLÍTÁSA ÉS VIZSGÁLATA}

\subsubsection{Nikkel nanorudak előállítása}

Első lépésként hőmérsékleti leválasztással a pórusos alumínium-oxid membrán (Whatman anodisc 25,13) alsó felén kb. 150-200 nm vastag ezüst réteget alakítottunk ki (5.2. ábra). Az általunk használt membrán $60 \mu \mathrm{m}$ mély és $\sim 0,2 \mu \mathrm{m}$ átmérőjü pórusokkal rendelkezett. A leválasztás során 10-12 membránhoz kb. $24 \mathrm{~cm}$ hosszú ezüstdrótot használtunk fel. Az elektrokémiai leválasztáshoz egy saját gyártású teflon mintatartót (5.1. A ábra) használtunk, amelynek alsó felére alumíniumfóliát hajtogattunk. A membránt az alsó felével helyeztük az alumíniumfóliára, és óvatosan ráhelyeztük a teflon mintatartó másik felét úgy, hogy a gumigyürü pontosan illeszkedjék a membrán széléhez.
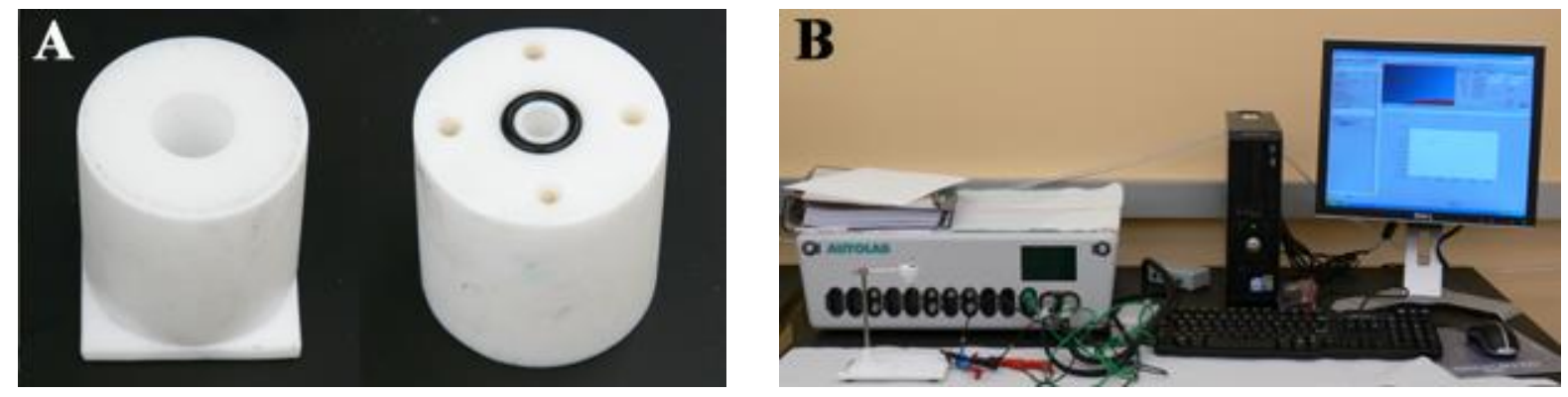

5.1. ábra: (A) Teflon mintatartó és (B) a potenciosztát.

Az ezüstréteg mint munkaelektród funkcionált az elektrokémiai leválasztás során. A három elektróddal ellátott potenciosztát (5.1. B ábra) rendszerben segédelektródként platinaelektródot, referenciaelektródként ezüst $(\mathrm{Ag} / \mathrm{AgCl})$ elektródot alkalmaztunk. A leválasztást megelőzően argon gázt buborékoltattunk át a nikkel-szulfát oldaton. A templátba történő leválasztás 1-1,5 órán keresztül 0,2 M-os nikkel-szulfát és 0,1 M-os bórsav elegyéből történt konstans $(-1 \mathrm{~V})$ feszültség mellett ${ }^{188}$. Az elektrokémiai leválasztást követően a membránt desztillált vízzel leöblítettük, majd salétromsavval óvatosan eltávolítottuk a membrán alsó felén található ezüstréteget. Ezt követően a templátot $3 \mathrm{M}$-os $\mathrm{NaOH}$-oldatba helyeztük 1 órára, majd a templát feloldódását követően eltávolítottuk a polimergyürüt és a nikkel nanorudakat desztillált vízzel semleges pH-ig mostuk és centrifugáltuk (9000 rpm). 


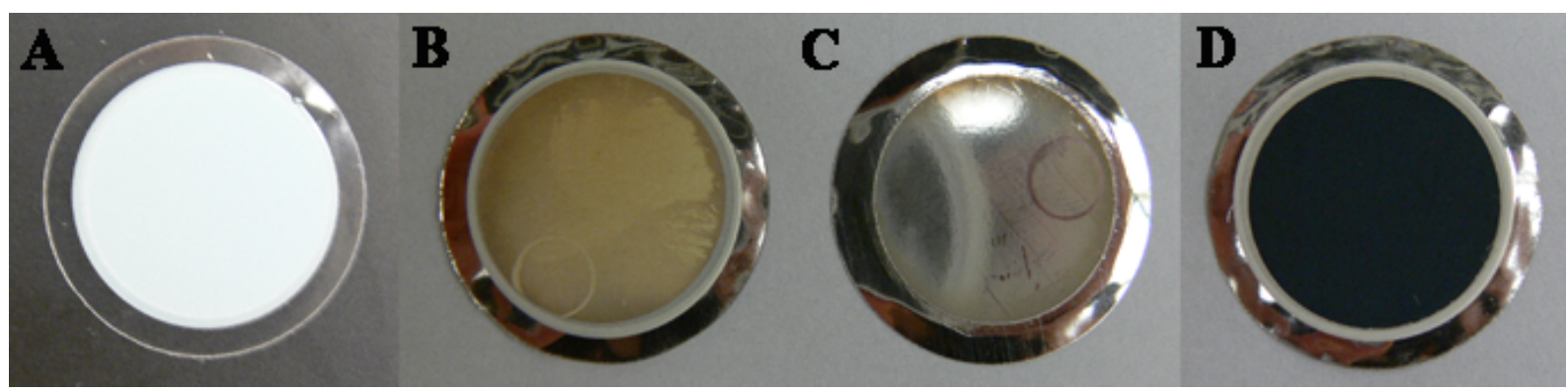

5.2. ábra: (A) A pórusos alumínium-oxid membrán, (B) a membrán felső oldala az ezüstleválasztást követően, (C) a membrán alsó oldala az ezüstleválasztást követően és (D) a membrán a nikkel elektrokémiai leválasztását követően.

\subsubsection{Pásztázó elektronmikroszkópia}
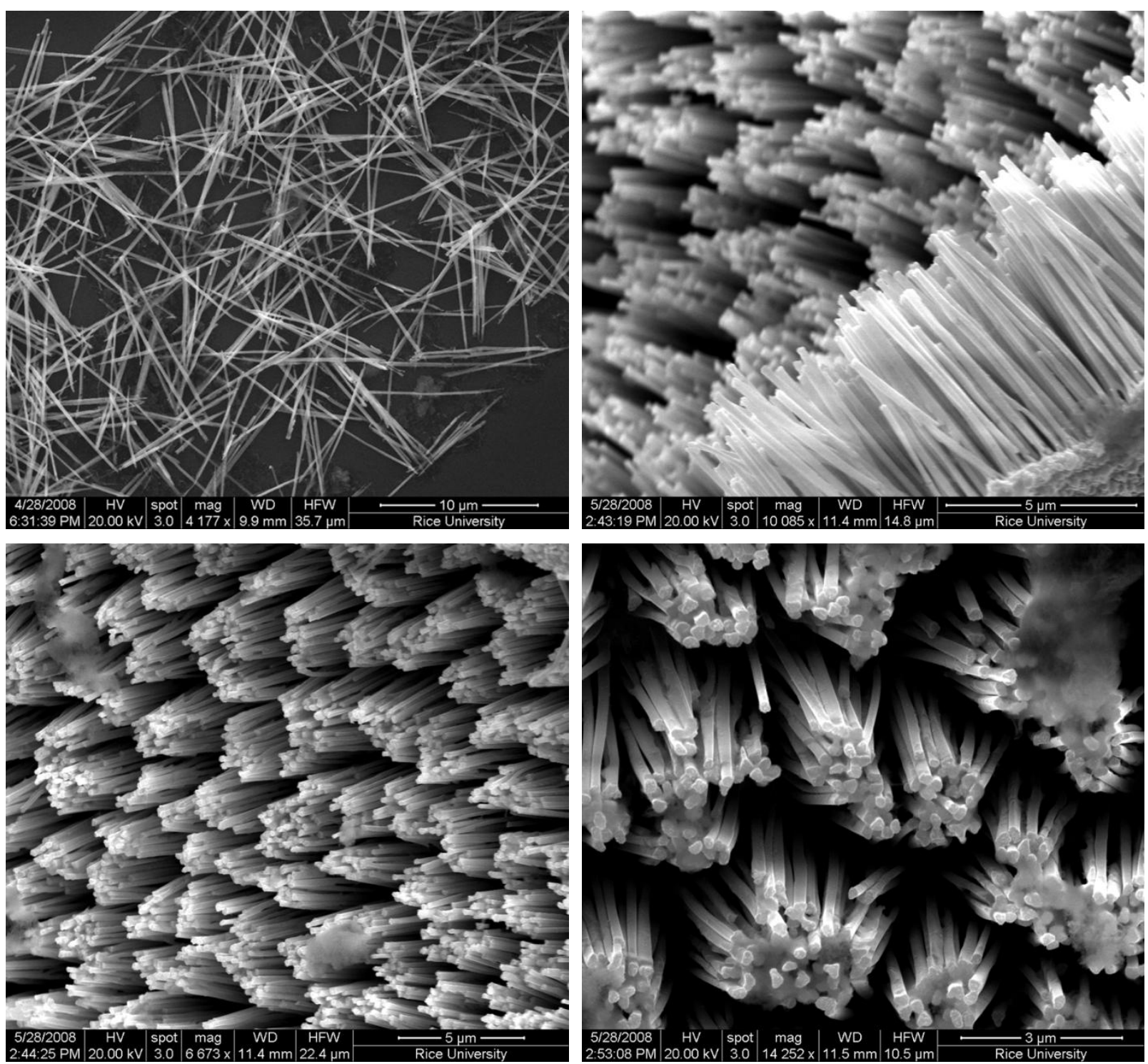

5.3. ábra: Nikkel nanorudak szabadon, illetve az ezüstrétegen rendezetten rögzítve a templát eltávolítását követően. 
A nikkel nanorudakat a membrán feloldását követően különböző módszerekkel jellemeztük. A pásztázó elektronmikroszkópiai felvételeken (5.3. ábra) jól látható, hogy a viszonylag egységesnek tekinthető nikkel nanorudak felszíne sima. Az ezüstréteg és a membrán eltávolítását követően szabadon álló nanorudakat kaptunk, míg ha csak a membránt távolítottuk el, a nanorudak rendezett struktúrát mutattak az ezüstrétegen.

A nanorudak méreteinek meghatározásához az Image Java szoftvert ${ }^{189}$ használtuk. Az 5.4. A ábra a nikkel nanorudak átmérőjének méreteloszlási hisztogramját mutatja. A nanorudak átméröje normál eloszlást követ, amely alapján az átlagos átmérőjük $202 \pm 49$ nm, hosszuk néhány mikrométer. A nanorudak átmérője jól követi a membrán pórusátméröit, amely $200 \mathrm{~nm}$ a membrán felső oldalán és kb. 20-50 nm a membrán alsó felén, ahol elágaznak a pórusok. Ez alapján a pórusok átmérői 150-300 nm közé esnek a membrán túlnyomó részén.

\subsubsection{Energiadiszperzív spektroszkópia}

Az EDS spektrumon (5.4. B ábra) jól láthatóak a nikkel csúcsai, valamint a szilícium és az alumínium vonala. Míg a szilícium vonala a mintatartóból, addig az alumínium a membránból visszamaradt szennyeződésből származik.
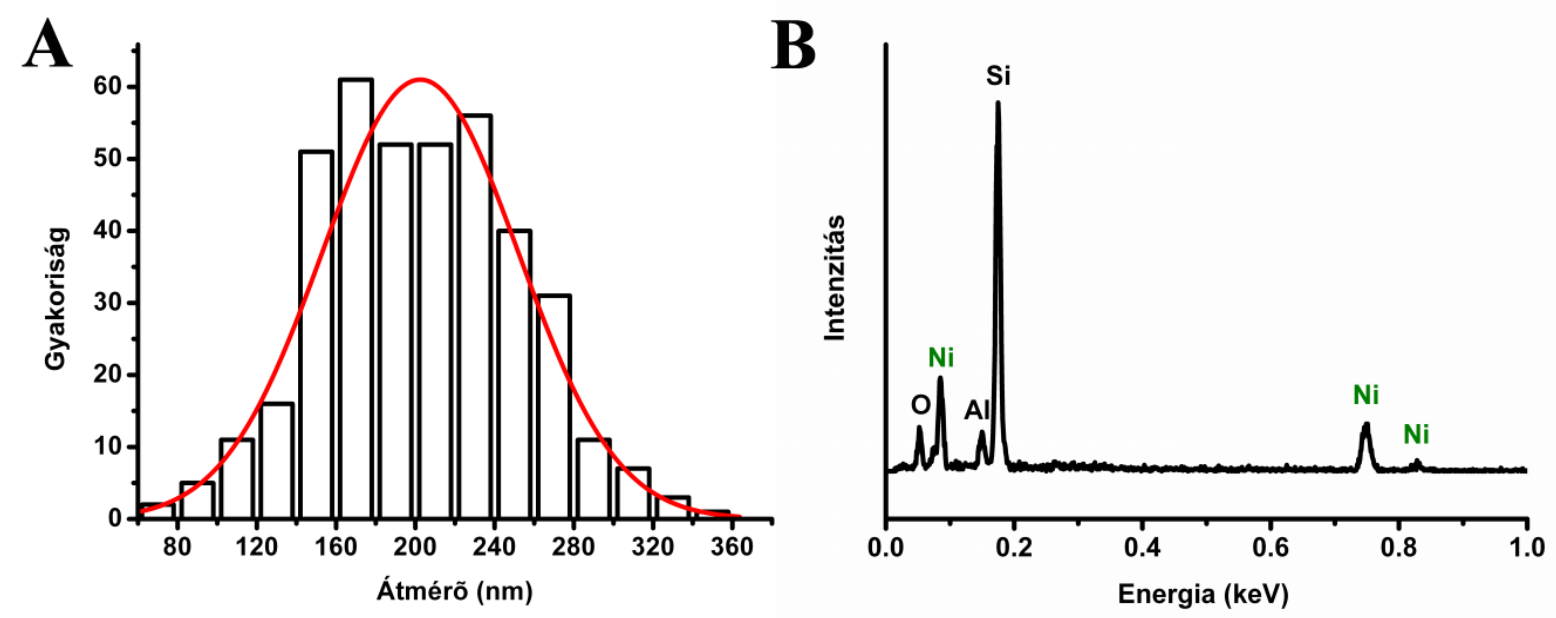

5.4. ábra: (A) Nikkel nanorudak méreteloszlási hisztogramja, (B) nikkel nanorudak EDS spektruma. 


\subsection{PÓRUSOS NEMESFÉM NANORUDAK ELÖÁLLÍTÁSA, VIZSGÁLATA ÉS ETILÉN HIDROGÉNEZÉSBEN TÖRTÉNŐ ALKALMAZÁSA}

\subsubsection{Pórusos nanorudak előállítása $(\mathrm{Au}, \mathrm{Pt}, \mathrm{Pd})$}

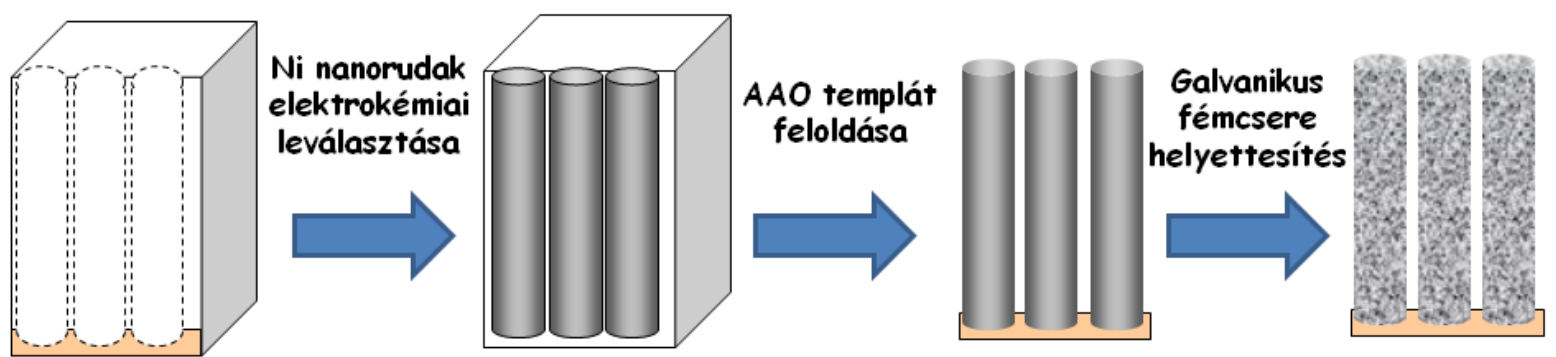

5.5. ábra: Pórusos nanorudak előállítási sémája (AAO - anódosan oxidált alumínium-oxid).

A nikkel a felületén kialakuló nikkel-oxid-rétegnek köszönhetően jól ellenáll a korróziónak, ezért a nanoszálakat hidrazin-monohidráttal, illetve nátrium-bórhidriddel redukáltuk a nemesfém nanorudak előállítását megelőzően. A redukciós lépés nélkül a szálak végein „sapkaszerü” aranyképződmények jelentek meg (5.6. ábra), illetve a nanorudak felületén némi aranykiválás volt látható. A 5.5. ábrán a galvanikus fémcsere helyettesítési reakció sémája látható.

\subsubsection{Pásztázó elektronmikroszkópia}
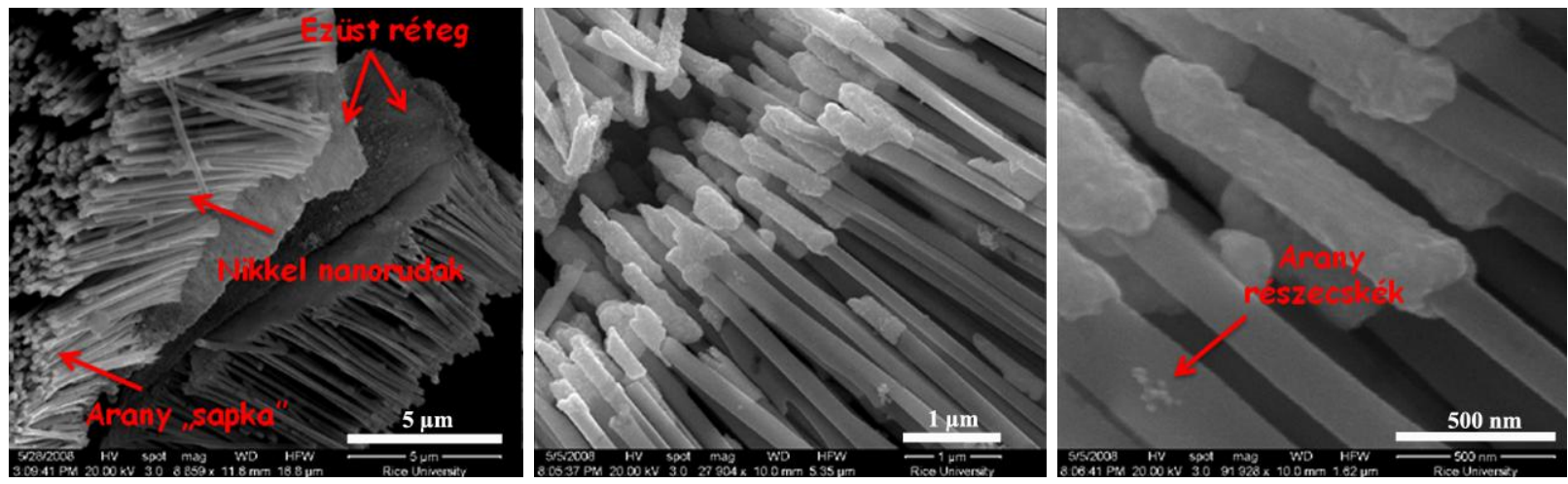

5.6. ábra: Nikkel nanoszálak „sapkával”, illetve a felületen kivált aranyrészecskék.

Amennyiben a galvanikus fémcsere helyettesítési reakciót redukciós lépés előzte meg, pórusos nemesfém nanorudakat kaptunk. A hidrazin-monohidráttal történő kezelést követően a nanorudakat $0,01 \mathrm{M}$-os $\mathrm{HAuCl}_{4}, \mathrm{~K}_{2} \mathrm{PtCl}_{6}$ vagy $\mathrm{K}_{2} \mathrm{PdCl}_{4}$ oldatba helyeztük és lassan kevertük. A nanorudakat 24 órás keverést követően desztillált vízzel mostuk és centrifugáltuk. A nanorudakról készült SEM felvételek az 5.7. ábrán láthatóak. 

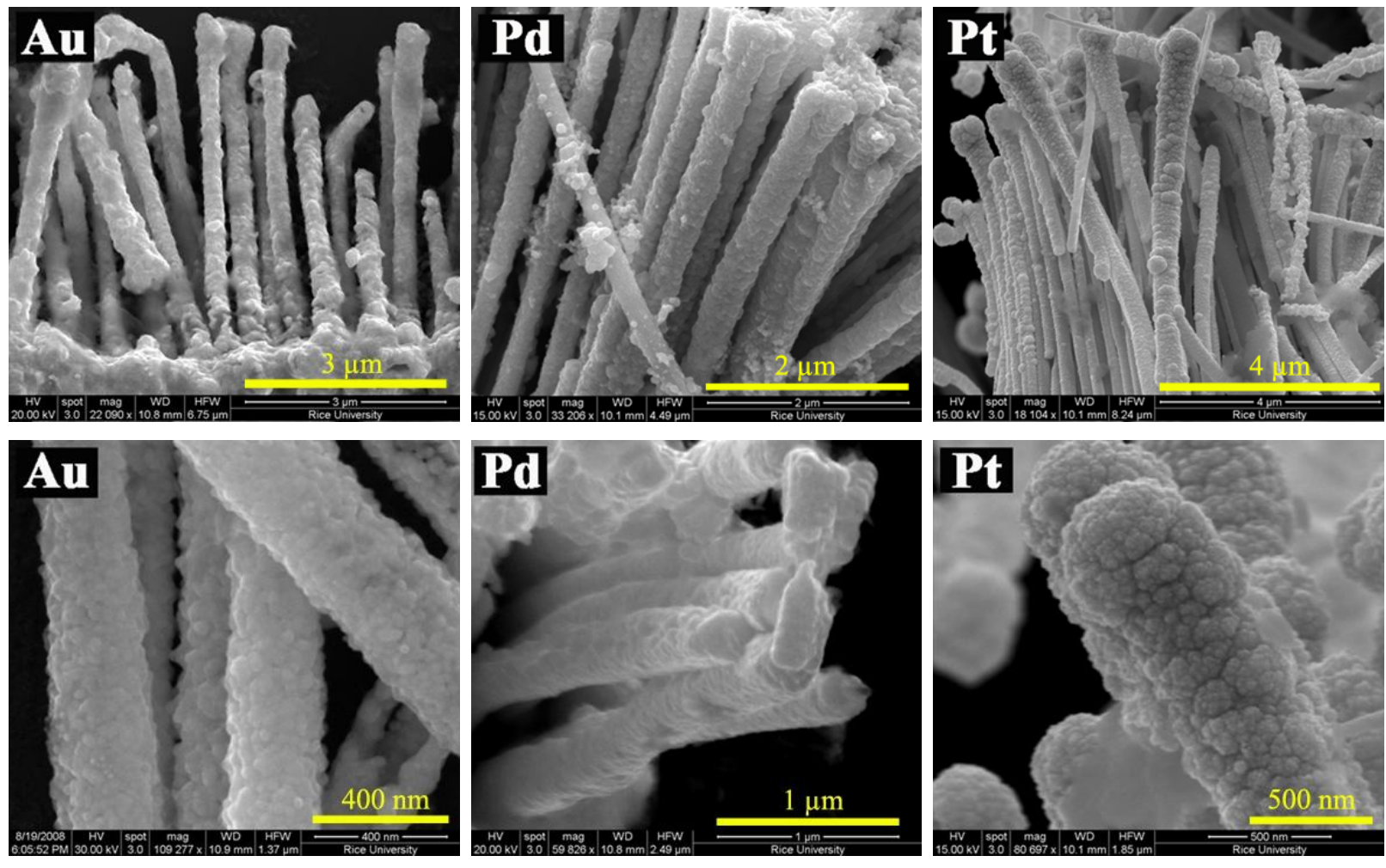

5.7. ábra: Pórusos nemesfém nanorudak.

Az elektronmikroszkópos felvételek alapján készített átmérő méreteloszlási hisztogramokat (5.8. ábra) normál eloszlással illesztettük meg. Az átlag átmérők $304 \pm 77$, $284 \pm 79$ és $259 \pm 69$ nm-nek adódtak az arany, palládium és platina nanorudak esetében. Fontos kiemelni, hogy a fémcserélt nanorudak átméröi nagyobbnak adódtak, mint a templátként alkalmazott nikkel nanorudak $(202 \pm 49 \mathrm{~nm})$ átlagos átmérője.
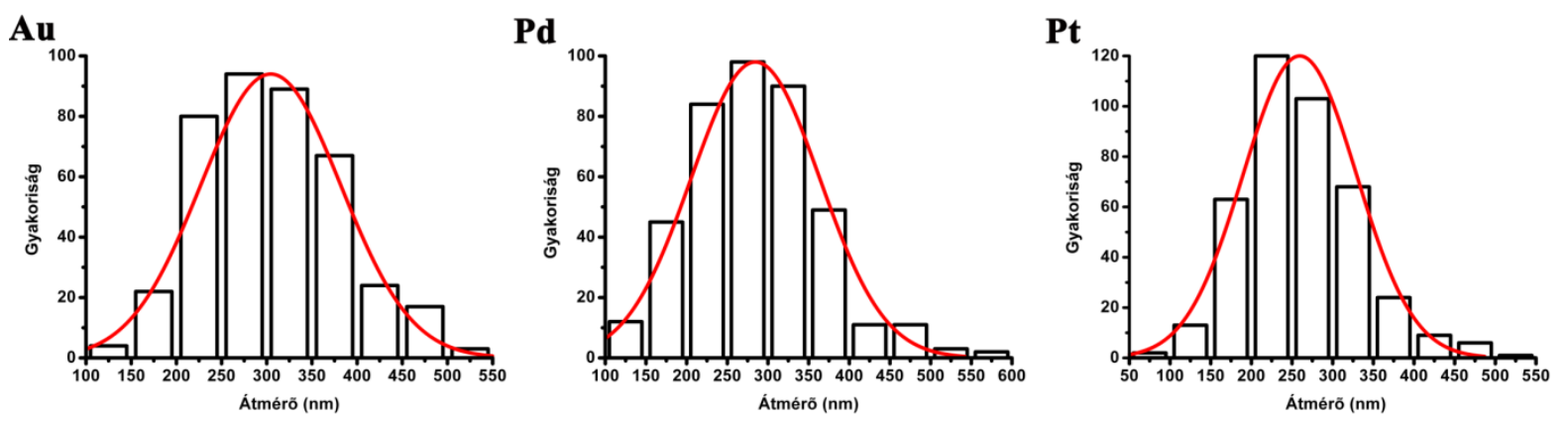

5.8. ábra: Méreteloszlási hisztogramok. 
A megvastagodás nem ismeretlen jelenség a fémcsere helyettesítési reakció folyamán, amikor pórusos nanoszerkezetek képződnek egy tömör szilárd templátból. Hasonló jellegü méretnövekedés volt észlelhető az $\mathrm{Au} / \mathrm{Pd}$ ötvözet nanoszerkezetek elöállításakor. A megvastagodás feltételezett oka a másodlagos növekedés, amely az ultravékony $\mathrm{Pd}$ nanoszálak és a toluolban oldott $\mathrm{AuCl}_{3}$ közt lejátszódó galvanikus fémcsere helyettesítési reakció során is megfigyelhetö ${ }^{190}$. Xia és munkatársai arany nanokalitkákat (nanocages) ezüst nanokockákból történő előállítása során a képződő nanoszerkezetek megnövekedését észlelték $^{153,154,191,192}$. Kimutatták, hogy a prekurzorként alkalmazott vegyületben az arany oxidációs száma is befolyásolta a nanokalitkák méretnövekedését ${ }^{153,154,191,192}$. A nikkel nanorudak fémcseréje során az általunk alkalmazott prekurzor molekulákban az Au, Pd és Pt +3 , +2 , és +4 oxidációs állapotokban van jelen. Habár a méretbeli eltérések okát nem vizsgáltuk mélyebben, az eltéréseket feltételezhetően az eltérő prekurzok hatására kialakuló, különböző morfológiai változások okozhatják. Ugyanakkor nem zárjuk ki a másodlagos növekedést a fémcsere helyettesítési reakció során, amely szintén jelentős eltéréseket okozhat a nanorudak átméröiben.

\subsubsection{Energiadiszperzív spektroszkópia és röntgen diffraktometria}

A nanorudak EDS spektrumait az 5.9. A ábra mutatja be. Mivel a mintákat szilícium egykristály lapra cseppentettük fel, egy igen intenzív szilíciumjel látható a spektrumok többségén. Az alumíniumjel a feltételezéseink szerint a nikkel elektrokémiai leválasztása során alkalmazott AAO templát maradványaiból származik. A nemesfém nanorudak esetében nikkelre utaló intenzitások nem jelentek meg a spektrumon. Az egyes spektrumok igazolták az arany, platina és a palládium jelenlétét a mintákban.

A fémcsere helyettesítési reakciót követően a nanorudakon röntgendiffrakciós vizsgálatokat végeztünk. Az 5.9. B ábra a nemesfém nanorudak röntgen diffraktogramjait mutatja be. A platina nanorudak esetében éles reflexiók jelentek meg a 20=40,1, 46,4, 67,9, 81,7 és $86,4^{\circ}$-nál, amelyek szinte teljes egyezést mutatnak a köbös lapcentrált (fcc) elemi cellákból felépülő platina (111), (200), (220), (311), és (222) kristálylapjaihoz tartozó reflexiókkal. A palládium és az arany nanorudak esetében a 20=40,0, 46,5, 68,0, 82,1 és $86,6^{\circ}$, valamint a $2 \theta=38,4,44,4,64,6,77,6$ és $81,8^{\circ}$ reflexiók szintén megfelelnek a lapcentrált köbös rács egyes lapjaihoz tartozó [(111), (200), (220), (311) és (222)] Bragg reflexióknak. A röntgen diffraktogramokon nikkelhez tartozó reflexiók nem jelentek meg, amely a nanorudak nikkeltartalmának teljes cseréjét igazolja. 

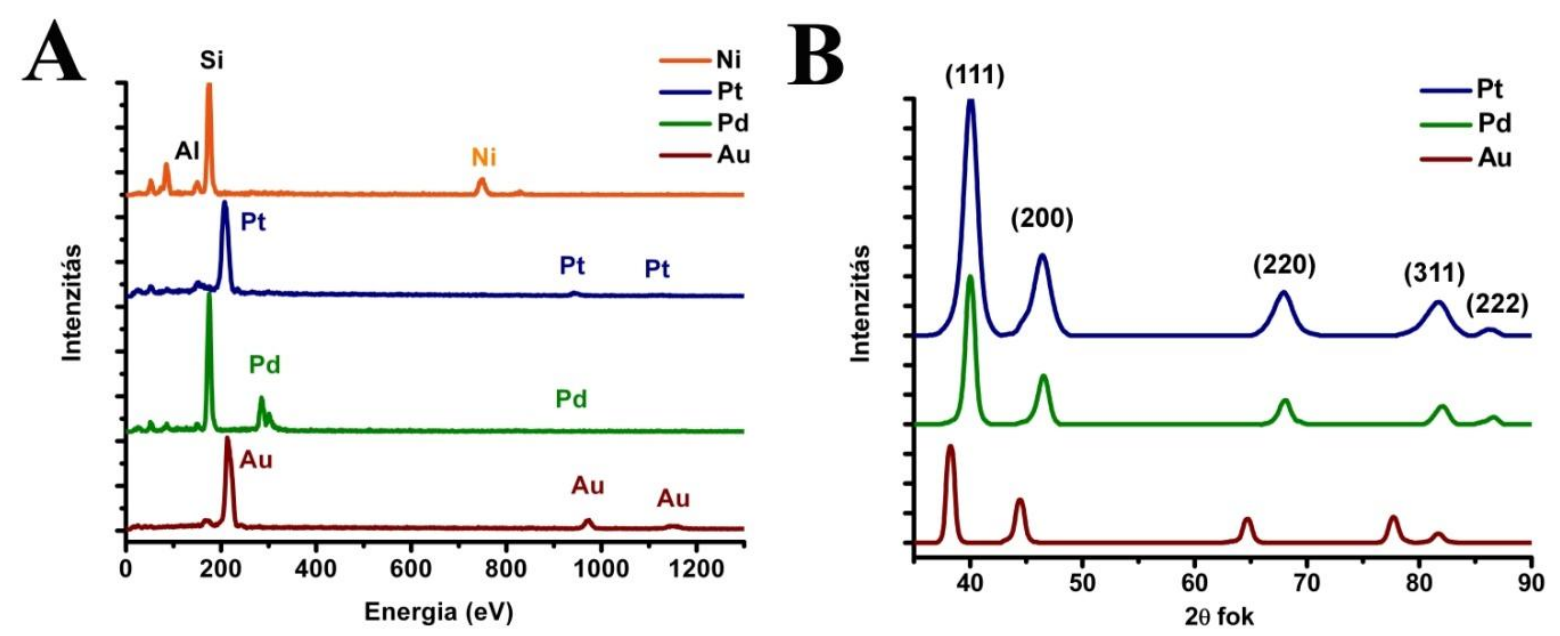

5.9. ábra: (A) Pórusos nanorudak EDS spektrumai és (B) röntgen diffraktogramjai.

\subsubsection{Röntgen fotoelektron spektroszkópia (XPS)}

$\mathrm{Az}$ áttekintő XPS spektrumon (5.10. ábra) a $\mathrm{C}_{1 \mathrm{~s}}, \mathrm{Au}_{4 \mathrm{f}}, \mathrm{Pt}_{4 \mathrm{f}}$, és $\mathrm{Pd}_{3 \mathrm{~d}}$ fotoelektron csúcsok jelentek meg. Semmilyen jel nem utal egyéb szennyezőanyag jelenlétére a spektrumokon.
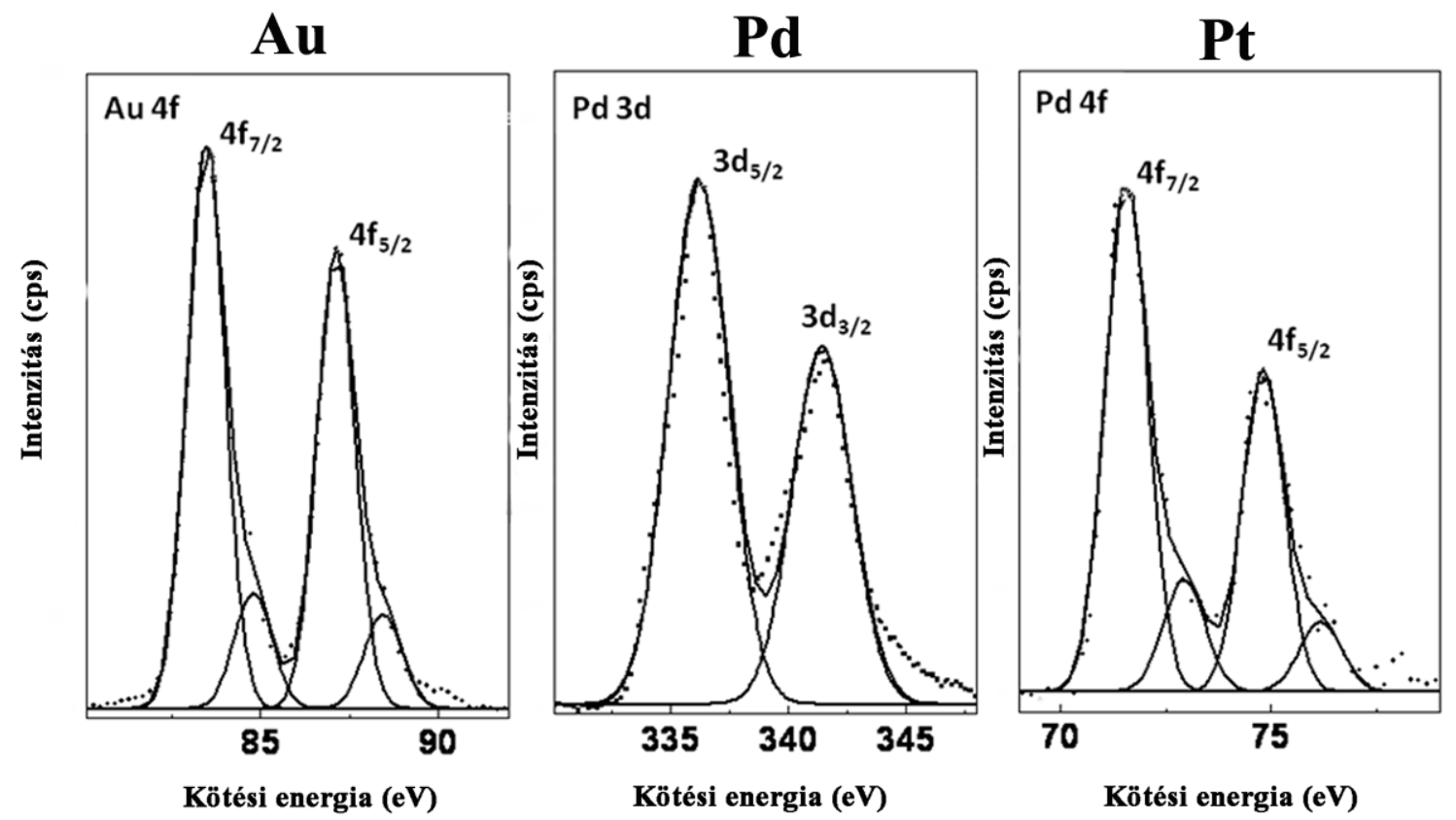

5.10. ábra: Röntgen fotoelektron spektrumok, Au, Pd és Pt nanorudakról. 
Az ábrán látható, hogy az $\mathrm{Au}_{4 \mathrm{f}}(7 / 2)$ csúcs dublettet alkot, amelynek oka a spin-pálya csatolás. A dekonvolúciót követően két csúcsot kapunk 83,4 és 84,7 eV-nál, melyek az Au(0) és $\mathrm{Au}(\mathrm{III})$ állapotaihoz tartoznak. Hasonlóan a $\mathrm{Pt}_{4 \mathrm{f}}$ fotoelektron csúcs is felbontható két spin-pálya párra 71,6 és 72,9 eV-nál, melyek a Pt(0) és a Pt(IV)-hez rendelhetők.

A Pd nanorudak esetében a $336 \mathrm{eV}$ kötési energiánál megjelenő $\mathrm{Pd}_{3 \mathrm{~d}}(5 / 2)$ fotoelektron csúcs a Pd(0)-ra utal. Az egyes nanorudak esetében kapott fotoelektron csúcsokhoz tartozó kötési energiák jól egyeznek az irodalomban közölt adatokkal ${ }^{193}$, igazolva ezzel, hogy a nanorudak nem tartalmaznak nikkelt, azaz a fémcsere helyettesítési reakció teljes mértékben végbement.

A SEM, XRD, XPS vizsgálatok egyértelmüen igazolták, hogy nikkel nanorudak galvanikus fémcsere helyettesítési reakciójával nemesfém nanorudak állíthatóak elő. Az önként végbemenő reakció hajtóereje a standard elektródpotenciálok különbségén alapul. Tekintve, hogy az $\mathrm{AuCl}_{4}{ }^{-} / \mathrm{Au}$ (0,99 V SHE-hoz képest), a $\mathrm{PtCl}_{6}{ }^{2-} / \mathrm{Pt}$ (0,735 V SHE-hoz képest), a $\mathrm{PdCl}_{4}{ }^{2-} / \mathrm{Pd}(0,59 \mathrm{~V}$ SHE-hoz képest) rendszer standard elektródpotenciálja nagyobb, mint a $\mathrm{Ni}^{2+} / \mathrm{Ni}$ rendszeré $(-0,250 \mathrm{~V}$ SHE-hoz képest), így a nikkel oxidációjával elemi állapotú nemesfémek képződnek. A reakciókat a következő egyenletek írják le:

$$
\begin{aligned}
2 \mathrm{Ni}(\mathrm{sz})+\mathrm{PtCl}_{6}{ }^{2-}(\mathrm{aq}) & \rightarrow \mathrm{Pt}(\mathrm{sz})+2 \mathrm{Ni}^{2+}(\mathrm{aq})+6 \mathrm{Cl}^{-}(\mathrm{aq}) \\
\mathrm{Ni}(\mathrm{sz})+\mathrm{PdCl}_{4}{ }^{2-}(\mathrm{aq}) & \rightarrow \mathrm{Pd}(\mathrm{sz})+\mathrm{Ni}^{2+}(\mathrm{aq})+4 \mathrm{Cl}^{-}(\mathrm{aq}) \\
3 \mathrm{Ni}(\mathrm{sz})+2 \mathrm{AuCl}_{4}^{-}(\mathrm{aq}) & \rightarrow 2 \mathrm{Au}(\mathrm{sz})+3 \mathrm{Ni}^{2+}(\mathrm{aq})+8 \mathrm{Cl}^{-}(\mathrm{aq})
\end{aligned}
$$

2. egyenlet: A fémcsere helyettesítéskor lejátszódó redoxi reakciók.

Ezüst nanoszerkezetek galvanikus fémcsere helyettesítési reakcióval arany, platina vagy palládium nanoszerkezetekké történő átalakulási mechanizmusa ismert és részletesen tárgyalt az irodalomban ${ }^{153,154,191,192,194}$. A tipikus reakciómechanizmust erre a rendszerre értelmezve, a $\mathrm{Ni}^{0}(\mathrm{sz})$ oxidációja során a $\mathrm{Ni}^{2+}(\mathrm{aq})$ ion a nanorudat körülvevő vizes közegbe történő kilépésével egy időben elemi állapotú Au, Pt vagy Pd képződik, amely a nanorudak felületén válik ki. Az oxidációs folyamat apró lyukak keletkezését eredményezi a nikkel nanorudakon, amelyen keresztül a nikkelatomok oxidálódva az oldatfázisba lépnek ki. Az ionok folyamatos diffúziójával egyre több nemesfém válik ki a nikkel nanorúd felületén, megtartva annak eredeti morfológiáját. A reakció végül a nikkel templát teljes „felemésztéséhez” vezet. 


\subsubsection{A fajlagos felület meghatározása}

Mivel a pórusos nanorudakat katalizátorként terveztük használni, fajlagos felületmeghatározást is végeztünk. A $\mathrm{N}_{2}$-adszorpciós mérések az 5.11. ábrán láthatóak. $\mathrm{A} \mathrm{Pt}$, Pd és $\mathrm{Au}$ nanoszálak fajlagos felülete 27, 31 és $30 \mathrm{~m}^{2} / \mathrm{g}$-nak adódott. Az általunk mért fajlagos felületetek összemérhetőek az irodalomban közölt platina aggregátumok $\left(39 \mathrm{~m}^{2} / \mathrm{g}\right)^{195}$ és a kereskedelmi forgalomban is beszerezhető platina fekete por $\left(20-26 \mathrm{~m}^{2} / \mathrm{g}\right)$ adataival. Tekintve hogy a nanorudak elöállítása során nem alkalmaztunk felületaktív anyagokat, illetve egyéb védőmolekulákat, ezért a potenciálisan elérhető felületek teljes mértékben részt tudnak venni a katalitikus reakcióban.
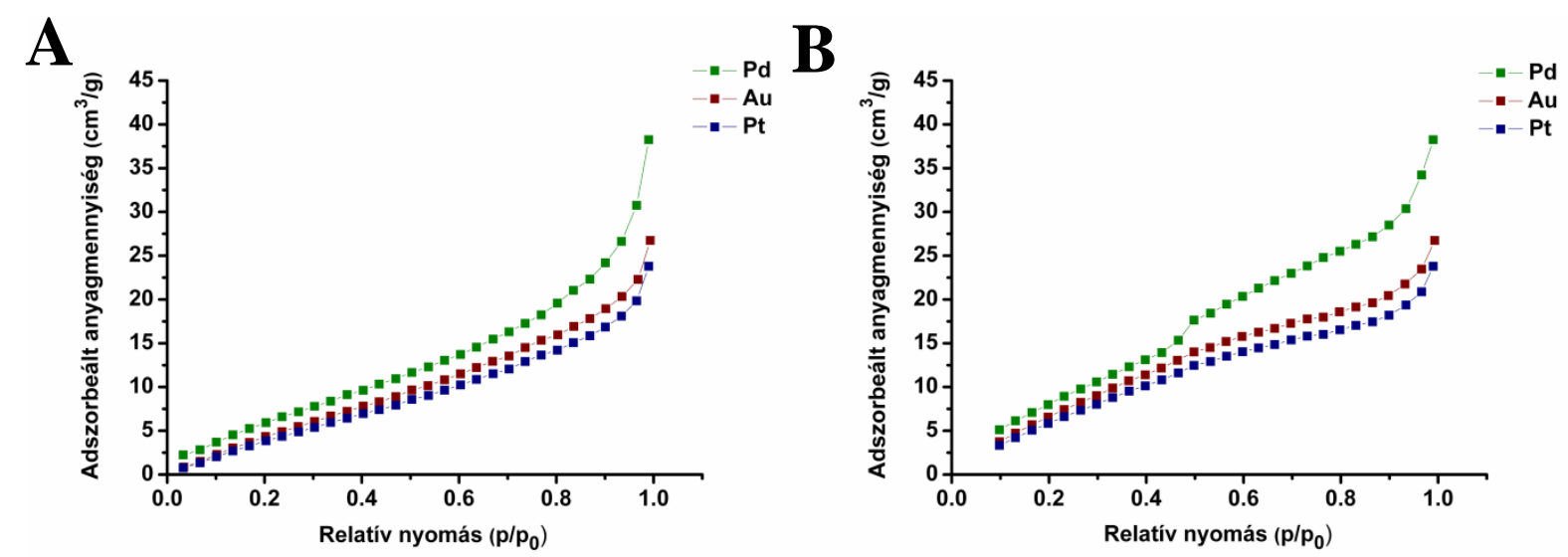

5.11. ábra: Pórusos nanorudak nitrogénadszorpciós (A) és -deszorpciós (B) izotermái.

\subsubsection{Stober szilika előállítása}

Mivel a pórusos nanoszálakat nem hordozós katalizátorként terveztük alkalmazni, a katalizátor homogén eloszlatása érdekében szilika nanorészecskéket használtunk hígító mátrixként. A $170 \mathrm{~nm}$-es átmérővel rendelkező monodiszperz szilika részecskéket a jól ismert Stöber-eljárás alapján készítettük el ${ }^{196,197}$. Ehhez $10 \mathrm{ml}$ ammónium-hidroxidot, $7 \mathrm{ml}$ desztillált vizet, $31 \mathrm{ml}$ etanolt és $1,7 \mathrm{ml}$ frissen desztillált tetraetoxi-szilánt kevertettünk egy éjszakán keresztül. Ezt követően a fehér színü szuszpenziót többször centrifugáltuk és mostuk. A szilikagömbökről készült mikroszkópos felvételeket az 5.12. ábra mutatja be. 

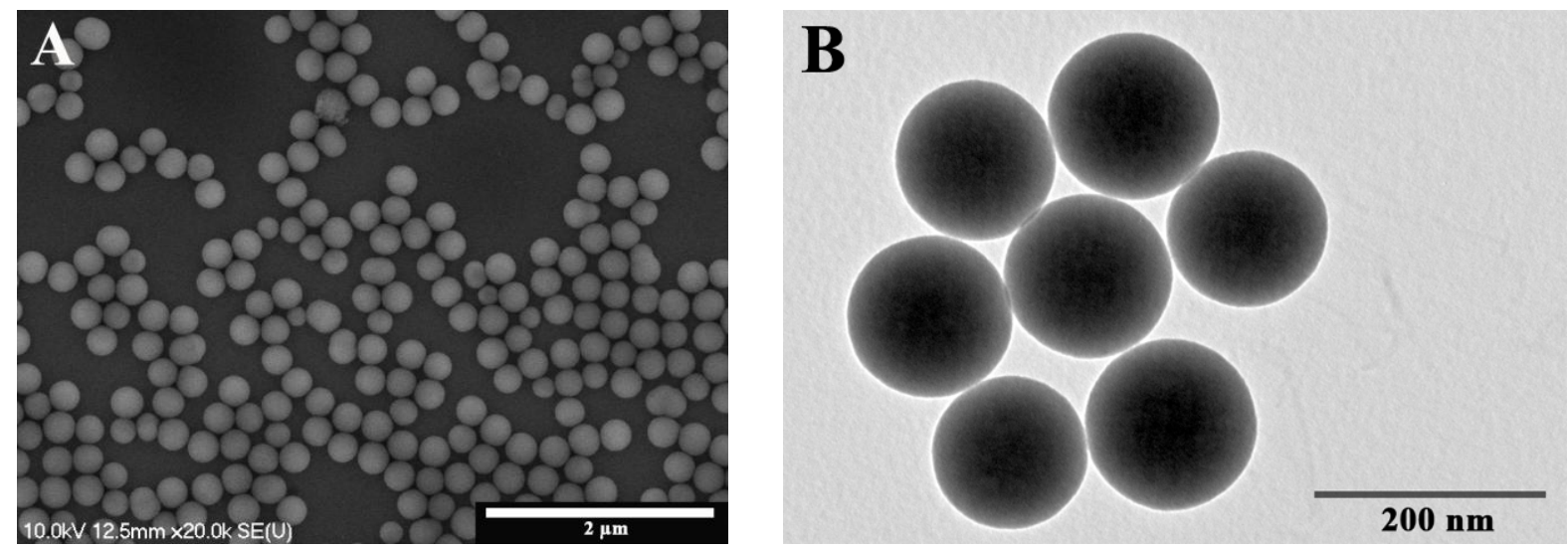

5.12. ábra: Stöber szilika SEM (A) és TEM (B) felvétele.

\subsubsection{Katalitikus mérések}

A katalizátorok tesztelése előtt ellenőriztük a Stöber szilika inaktivitást az etilén hidrogénezése során. Ehhez tiszta szilikarészecskéket mértünk be és teszteltük a kívánt hőmérséklettartományban. A szilika nanorészecskék nem mutattak katalitikus aktivitást az etilén hidrogénezési reakcióban.

A katalitikus mérések során minden esetben $1 \mathrm{mg}$ Pt vagy Pd nanoszálat kevertünk össze $1 \mathrm{~g}$ szilikával, hogy biztosítsuk a gázfázisú reaktánsok és a katalizátor közötti megfelelö érintkezést. Ezt követően a katalizátort az üvegcsőbe helyeztük, amelyet atmoszférikus nyomáson teszteltünk. A katalizátort reduktív atmoszférában aktiváltuk a mérések előtt $623 \mathrm{~K}$-en $\left(350^{\circ} \mathrm{C}\right.$-on). A reduktív atmoszférát hidrogéngáz alkalmazásával biztosítottuk $30 \mathrm{~cm}^{3} /$ perc áramlási sebességet alkalmazva.

A tesztreakciók során nagytisztaságú etilén és hidrogén gázelegyet használtunk, $2 \mathrm{~cm}^{3} /$ perc és $40 \mathrm{~cm}^{3} /$ perc áramlási sebességet beállítva. A méréseket $263-313 \mathrm{~K}\left({ }^{-} 10-{ }^{+} 40{ }^{\circ} \mathrm{C}\right)$ hőmérséklettartományban végeztük azért, hogy a konverziót megfelelően alacsonyan tudjuk tartani ( $5 \%$ alatt), az aktiválási energia meghatározásának érdekében.

Az etilénhidrogénezés aktiválási energiáját Pd és Pt nanorudakon határoztuk meg. Minden egyes katalitikus mérést legalább 5-ször megismételtünk. Az 5.13. ábrán látható hibahatárok az egyes mérések közti eltéréseket jelölik. A mért konverzió adatokat normalizáltuk a felületen lévő atomok számára, így TOR (turnover rate - egy aktív helyen 1 másodperc alatt lejátszódó átalakulások száma) értékeket kaptunk. A TOR számolások a $\mathrm{N}_{2^{-}}$ adszorpciós mérések során kapott fajlagos felületek és az irodalomban található felületi atomok számának adatain alapulnak, amelyek $\mathrm{Pt}^{198}$ esetében $1,505 \times 10^{15}$ atom/ $/ \mathrm{cm}^{2}$, a $\mathrm{Pd}^{199}$ esetében $1,53 \times 10^{15}$ atom $/ \mathrm{cm}^{2}$. Feltételeztük, hogy a reakció során minden egyes atom egy 
aktív helyként funkcionál. A TOR mindkét esetben emelkedett a vizsgált hőmérséklettartományban (263-313 K).

A platina nanorudak esetében a TOR változása meredekebben történt, mint a $\mathrm{Pd}$ nanorudaknál. A jelenség nem meglepő, hasonló jellegü különbséget észleltek hordozós Pt és Pd nanorészecskéken végzett katalitikus kísérletekben ${ }^{200}$. A katalizátor aktivitását számos tényező, így a katalizátor felszínén a reaktánsok adszorpciója (jelen esetben a hidrogén és az etilén) és a termék(ek) (etán) deszorpciója is befolyásolja. Az eltérő felszíneken a kemiszorpciós energiákban lévő különbségek magyarázatul szolgálnak a TOR és az aktiválási energiákban mutatkozó különbségekre.

\begin{tabular}{|c|c|c|c|}
\hline Katalizátor & Hömérséklet & Aktiválási energia & Hivatkozás \\
\hline Elméleti & $-25-163^{\circ} \mathrm{C}$ & $37,7-50,2 \mathrm{~kJ} / \mathrm{mol}$ & \\
& $(248-436 \mathrm{~K})$ & $(9-12 \mathrm{kcal} / \mathrm{mol})$ & \\
\hline $\mathrm{Pd}(111)$ felszínen & $27-202^{\circ} \mathrm{C}$ & $35 \pm 1 \mathrm{~kJ} / \mathrm{mol}$ & \\
& $(300-475 \mathrm{~K})$ & $(8,37 \mathrm{kcal} / \mathrm{mol})$ & \\
\hline $\mathrm{Pd}$ film & $-80-150{ }^{\circ} \mathrm{C}$ & $44,8 \mathrm{~kJ} / \mathrm{mol}$ & \\
& $(193-423 \mathrm{~K})$ & $(10,7 \mathrm{kcal} / \mathrm{mol})$ & \\
\hline $\mathrm{Pd} /$ Grafit & $0-50{ }^{\circ} \mathrm{C}$ & $20-40 \mathrm{~kJ} / \mathrm{mol}$ & \\
modellkatalizátor & $(273-323 \mathrm{~K})$ & $(4,78-9,56 \mathrm{kcal} / \mathrm{mol})$ & \\
\hline Kereskedelmi & $30-80{ }^{\circ} \mathrm{C}$ & $40 \mathrm{~kJ} / \mathrm{mol}$ & \\
$\mathrm{Pd} / \mathrm{Al}_{2} \mathrm{O}_{3}$ & $(303-353 \mathrm{~K})$ & $(9,56 \mathrm{kcal} / \mathrm{mol})$ & \\
\hline
\end{tabular}

5.1. táblázat: Pd-katalizátorok etilén hidrogénezésben mutatott aktiválási energiái.

Amint az irodalomból ismeretes, az etilén, acetilén, propilén, ciklopropán és hasonló molekulák a C-H kötés bomlásával disszociatíven adszorbeálódnak a fémek (pl.: Ni, Pd, Pt és Al) felszínén ${ }^{206}$. Cheng és munkatársai kimutatták, hogy a Pt nanorészecskék nagyobb hidrogénadszorpciós kapacitással bírnak, mint a Pd nanorészecskék, mivel a $\mathrm{H} 1 \mathrm{~s}$ és a Pt $5 \mathrm{~s}$ elektronpályák között erösebb kölcsönhatás alakul ki, mint a $\mathrm{H} 1 \mathrm{~s}$ és $\mathrm{Pd} 4 \mathrm{~d}$ pályák között ${ }^{200,207}$. Franken és Ponec méréseket végzett a kilépési munka változására $(\Delta \Phi)$ az etilén különböző fémfelszíneken $(\mathrm{Ni}, \mathrm{Pd}, \mathrm{Pt}$, $\mathrm{Au}, \mathrm{Al}$, és $\mathrm{Cu})$ történő adszorpciója során ${ }^{208}$. Méréseik alapján a Pt esetében ez a változás nagyobb volt, mint a Pd esetében.

Ezekből a mérésekből fény derült arra, hogy azonos reakciókörülmények között a Pt nagyobb felületi borítottsággal rendelkezik, mint a Pd. Nagy felületi borítottság esetén erōs taszítás lép fel az adszorbeátumok között, amely a szén-fém és a hidrogén-fém kötések meggyengüléséhez vezet, megkönnyítve ezzel a hidrogén szén-fém kötésbe történő belépését. A fém és az adszorbeátum közt lévő kötés erősségének gyengülése a hidrogénezési reakció aktiválási gátjának csökkenését eredményezi ${ }^{208}$. A szénhidrogénnel borított Pt-felszínen a 
hidrogénezés és a termék deszorpciója könnyebben megy végbe, mint más fémfelületeken ${ }^{209}$. Ez magyarázatot adhat a platinán mért görbék meredekebb emelkedésére.

\begin{tabular}{|c|c|c|c|}
\hline Katalizátor & Hömérséklet & Aktiválási energia & Hivatkozás \\
\hline $\mathrm{Pt} / \mathrm{SiO}_{2}$ & $-50-25^{\circ} \mathrm{C}$ & $37,2-38 \mathrm{~kJ} / \mathrm{mol}$ & 210 \\
& $(223-298 \mathrm{~K})$ & $(8,9-9,1 \mathrm{kcal} / \mathrm{mol})$ & \\
\hline $\mathrm{Pt} / \mathrm{SiO}_{2}$ & $-70-85^{\circ} \mathrm{C}$ & $10,5 \mathrm{kcal} / \mathrm{mol}$ & \\
& $(203-188 \mathrm{~K})$ & $(43,9 \mathrm{~kJ} / \mathrm{mol})$ & \\
\hline $\mathrm{Pt} / \mathrm{SiO}_{2}$ & $45-150^{\circ} \mathrm{C}$ & $16,0 \mathrm{kcal} / \mathrm{mol}$ & \\
& $(318-423 \mathrm{~K})$ & $(66,9 \mathrm{~kJ} / \mathrm{mol})$ & \\
\hline $\mathrm{Pt}-$ drót & $50-100^{\circ} \mathrm{C}$ & $10,0 \mathrm{kcal} / \mathrm{mol}$ & \\
& $(323-373 \mathrm{~K})$ & $(41,8 \mathrm{~kJ} / \mathrm{mol})$ & \\
\hline
\end{tabular}

5.2. táblázat: Pt-katalizátorok etilén hidrogénezésben mutatott aktiválási energiái ${ }^{210}$.

Az 5.13. ábra az elméleti becslés alapján meghatározott aktív helyeken a másodpercenként átalakult molekulák számát mutatja. A jobb oldali grafikonon az Arrhenius görbék láthatók ( $50^{\circ} \mathrm{C}$-os hőmérséklettartományban), melyekből meghatároztuk a látszólagos aktiválási energiákat. Ez 43,7 $\pm 1,7 \mathrm{~kJ} \mathrm{~mol}^{-1}$ a Pt és $29,4 \pm 1,3 \mathrm{~kJ} \mathrm{~mol}^{-1}$ a Pd nanorudak esetében $^{214}$, ami jó egyezést mutat az irodalmi értékekkel.
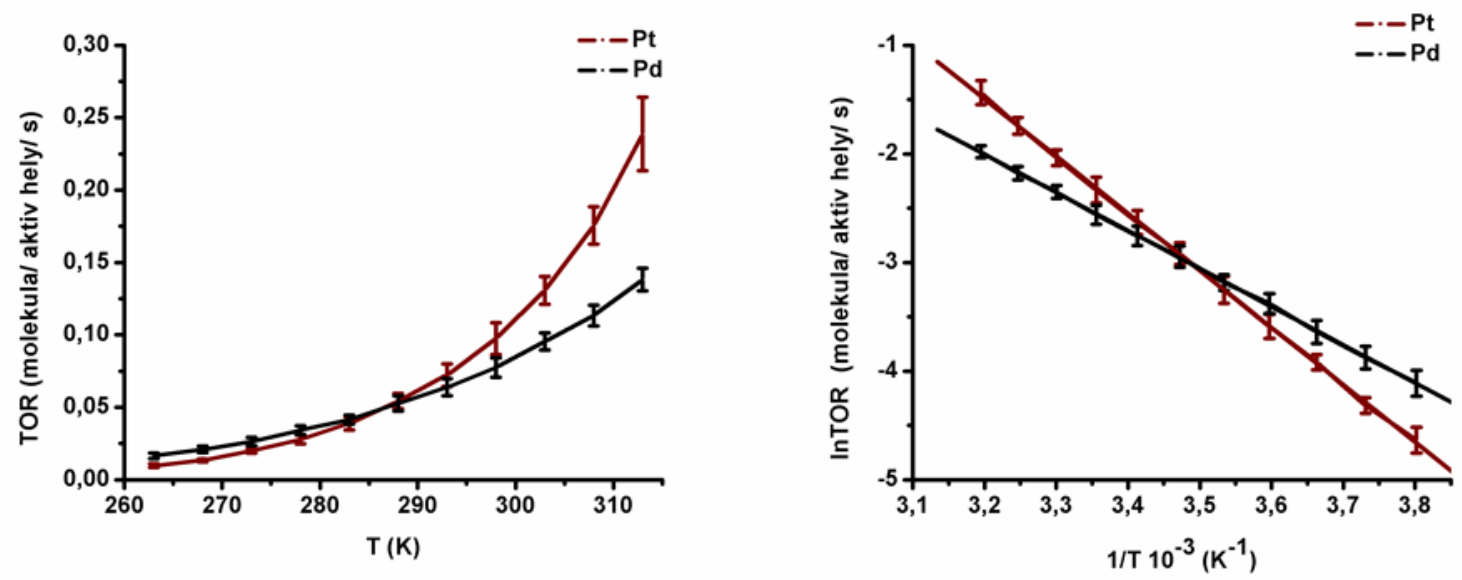

5.13. ábra: TOR értékek a hőmérséklet függvényében (bal) és Arrhenius görbék (jobb).

Az etilén hidrogéntelítési reakciójának hordozós palládiumkatalizátorokon mért aktiválási energiái $27,2-44,8 \mathrm{~kJ} \mathrm{~mol}^{-1}$-es tartományba esnek ${ }^{202}$. A mérések alapján a nem hordozós Pt és Pd nanorudak hasonló aktiválási energiákat mutatnak az etilén hidrogénezésében, mint a hordozós Pd nanorészecskék. Az 5.1. táblázat és az 5.2. táblázat 
néhány, az irodalomban közölt, az etilén hidrogénezésének Pd- és Pt-katalizátoron meghatározott aktiválási energiaértékeit foglalja össze a teljesség igénye nélkül.

\subsubsection{Etilén hidrogénezés membránba ágyazott palládium nanorészecskéken}

Az általunk kidolgozott módszerrel poli-dimetil-sziloxán (PDMS) membránba ágyazott palládium részecskéken is meghatároztuk az etilén hidrogénezés aktiválási energiáit $^{215}$. A PDMS membrán előállításához az elasztomert és a térhálósítót (10:1 tömeg arányban) összekevertük és vákuumkamrába helyeztük, hogy a buborékokat eltávolítsuk. A nanorészecskéket tartalmazó minták elkészítéséhez 0,1 M-os palládium-acetilacetonát metilén-kloridos oldatából 5, illetve 10 ml-t adtunk 5 g PDMS-hez (1, illetve $2 \mathrm{~m} / \mathrm{m} \%$-os mintákat kaptunk). Ezt követően a Pd-tartalmú PDMS-t üveglapra öntöttük és vákuumban szárítottuk, majd $623 \mathrm{~K}$-en $15 \% \mathrm{H}_{2} / \mathrm{Ar}$ atmoszférában 1 órán keresztül hőkezeltük.

A korábbi katalitikus mérésekkel analóg módon a mintákat reduktív atmoszférában $\left(30 \mathrm{~cm}^{3} /\right.$ perc $\mathrm{H}_{2}, 1$ h) $623 \mathrm{~K}$-en aktiváltuk. A mérések során $20 \mathrm{~cm}^{3} /$ perc $\mathrm{H}_{2}, 30 \mathrm{~cm}^{3} /$ perc $\mathrm{N}_{2}$ és $2 \mathrm{~cm}^{3} /$ perc etilén keverékét alkalmaztuk. A kísérletek során megvártuk, míg beállt a stacionárius állapot, a konverzió értékeket $5 \%$ alatt tartottuk és minden egyes mérést legalább 5-ször megismételtünk. A TOR értékek mindkét minta esetében emelkedést mutattak a $40 \mathrm{~K}$-es $\left({ }^{-} 9-^{+} 32^{\circ} \mathrm{C} / 264-305 \mathrm{~K}\right)$ hőmérséklettartományban. A TOR értékeket normalizáltuk a felületen található atomok számára. Ebben az esetben is az irodalmi adatokat használtuk fel a felületi atomok számának megbecsülésére $\left(1,53 \times 10^{15} \text { atom/ } / \mathrm{cm}^{2}\right)^{199}$ és a TEM mérések alapján meghatározott 4,8 $\pm 0,6 \mathrm{~nm}$-es Pd nanorészecskéket $\{111\}$ lapokkal határolt, gömböt közelítő alakúnak tételeztünk fel. Az Arrhenius görbék segítségével meghatározott látszólagos aktiválási energiák 2,4 és 2,3 kcal/mol-nak (10 és 9,6 kJ/mol) adódtak az 1, illetve $2 \mathrm{~m} / \mathrm{m} \%$ os minták esetében. Habár a $2 \mathrm{~m} / \mathrm{m} \%$-os membrán kétszer annyi $\mathrm{Pd}$ nanorészecskét tartalmazott, mint az $1 \mathrm{~m} / \mathrm{m} \%$-os membrán, a konverzió értékek csak 1,3-szeres emelkedést mutattak. A nagyobb Pd tartalom ellenére, feltehetően a nanorészecskék aggregációja miatt, az aktív helyek száma nem duplázódott meg. A szokatlanul alacsony aktiválási energia értékekért a jelentős mértékben korlátolt anyagtranszport a felelős ${ }^{216}$ így valószínüsíthető, hogy a reakció a felszínhez közeli régióban játszódik le. 


\subsection{RÉZ NANOSZÁLAK ELŐÁLLÍTÁSA, JELLEMZÉSE ÉS ELEKTROMOS TULAJDONSÁGAINAK VIZSGÁLATA}

\subsubsection{Réz nanoszálak előállítása}

A réz nanoszálak előállítását hidrotermális úton végeztük. Ehhez egy Erlenmeyer lombikban $80 \mathrm{ml}$ desztillált vízhez $1 \mathrm{mmol}(0,17 \mathrm{~g})$ kristályvizes réz-kloridot és $2 \mathrm{mmol}$ (0,391 g) D-glükózt adtunk. Ezt követően gyors keverés mellett 6 mmol 1-hexadecil-amint (HDA) adtunk az oldathoz. Mivel a HDA rosszul oldódik vízben, az oldatot 5 órán keresztül kevertettük (550 rpm), majd teflonbéléses rozsdamentes acél autoklávba töltöttük, és $120^{\circ} \mathrm{C}$-on forgatva 24 órán keresztül hőkezeltük. Miután az autokláv szobahőmérsékletüre hült, a nanoszálakat desztillált vízzel, etanollal, hexánnal mostuk és centrifugáltuk $(2000 \mathrm{rpm})^{52}$, hogy eltávolítsuk a nanoszálak felületén visszamaradt HDA-t. A mosást követően egy vörösesbarna anyagot kaptunk, amelyet etanol alatt tároltunk, hogy megóvjuk az oxidatív atmoszférától.

\subsubsection{Morfológiai és szerkezeti jellemzés}

A termék a nanoszálak mellett nanorészecskéket is tartalmazott. A centrifugálás paraméterei kritikusnak bizonyultak a nanoszálak nanorészecskéktől történő elválasztásának tekintetében. A Xia és munkatársai által Ag nanoszálak nanorészecskéktől történő elválasztására kidolgozott ${ }^{52} 2000$ rpm-es fordulatszám eredményesnek bizonyult a mi esetünkben is. A szárítást követően a hozam kb. $50 \%$-nak adódott. A veszteség jelentős részéért feltételezhetően a tisztítási folyamat felelős.

Az 5.14. A ábra réz nanoszálakat mutat 245000-szeres nagyításban. A TEM felvétel mellett az elektrondiffrakciós felvétel (5.14. B ábra) látható, amely igazolta a nanoszálak egykristályos voltát. A nanoszálak morfológiáját és méreteit SEM-mel is vizsgáltuk. Az 5.15. A ábra egy tipikus SEM felvétel a réz nanoszálakról, amelyen jól látható, hogy a termék nagy mennyiségben tartalmaz nanoszálakat, amelyek átlagos átmérője $64 \pm 8 \mathrm{~nm}$, míg hosszuk a mikrométeres mérettartományba esik. A méréseink alapján a becsült hossz/átmérő arány 50 feletti, következésképpen a módszer alkalmas réz nanoszálak nagy mennyiségben történő előállítására. 

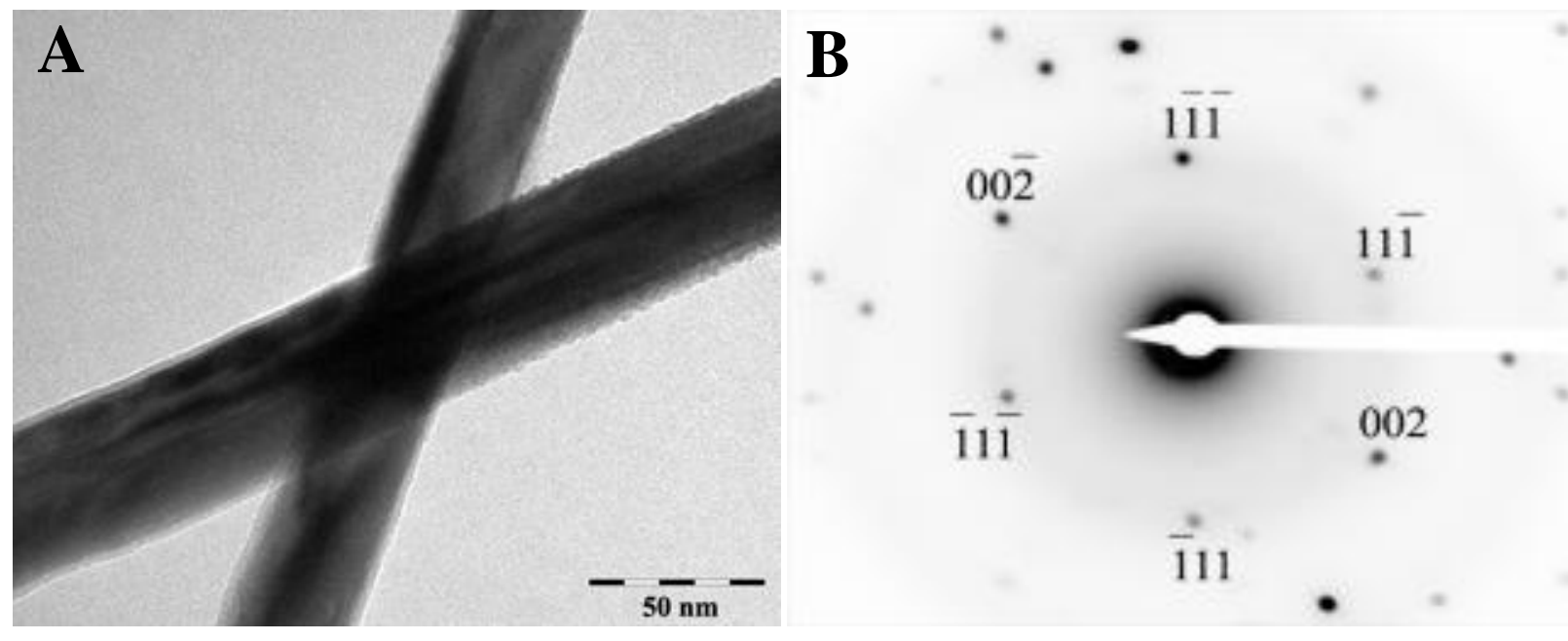

5.14. ábra: (A) TEM és (B) ED felvétel a Cu nanoszálról.

Az elektronmikroszkópos felvételek (5.15. A ábra) alapján a nanoszálak többnyire egyenesek, és csak helyenként tartalmaznak szögletes irányváltásokat/elfordulásokat. Feltételezéseink szerint ezek az elfordulások egy kristály több kristálylapján szimultán végbemenő anizotróp kristálynövekedés eredményei. Bár az elektrondiffrakciós mintázatok alapján a nanoszálak egykristály szerkezetűek, az elfordulásokat is figyelembe véve úgy gondoljuk, hogy a nanoszálakat mikrométeres hosszúságú egykristályos egységek építik fel.

A nanoszálak kémiai összetételét EDS-sel vizsgáltuk, amelynek eredményét az 5.15. B ábra mutatja be. A spektrumon jól láthatóak az Al (1,48 keV), Si (1,74 keV), és $\mathrm{Cu}$ (8,07 és $8,92 \mathrm{keV})$ vonalai. A réz Ka vonala egyértelmüen igazolja, hogy a mintában lévő nanoszálak rézből épülnek fel, míg a szilícium és az alumínium jele a mintatartóból ered.
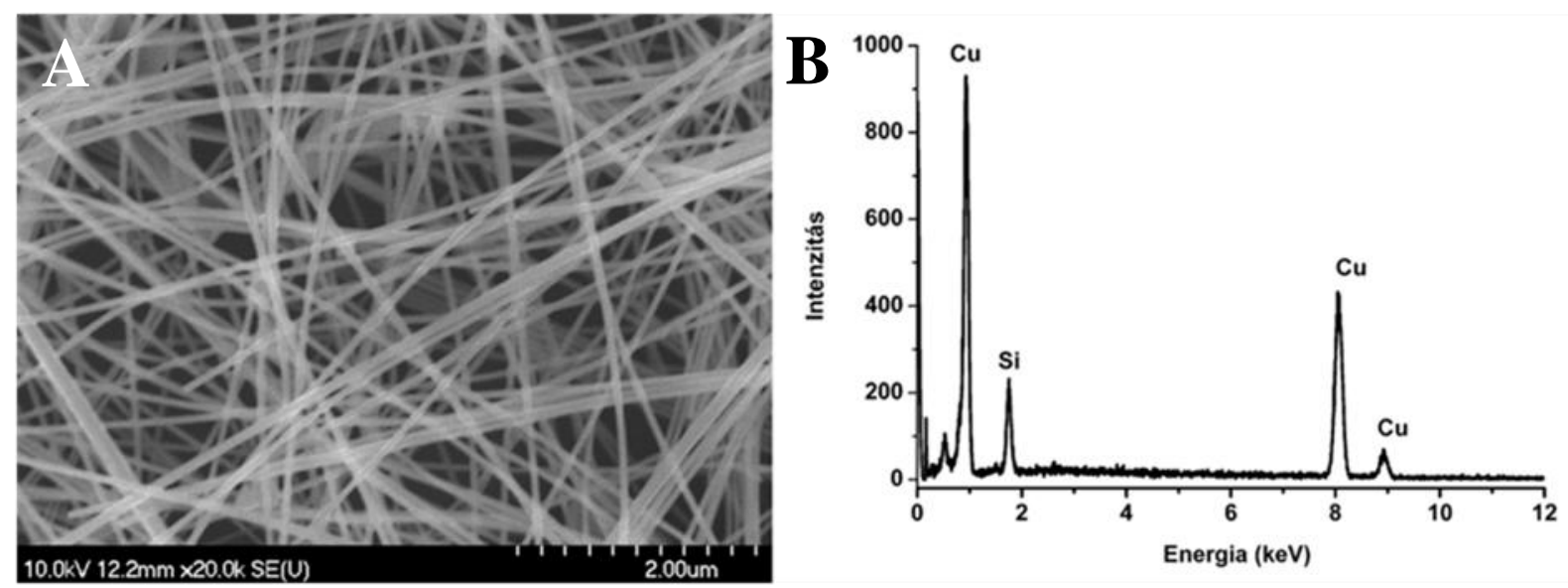

5.15. ábra: Réz nanoszálak SEM képe és EDS spektruma. 
Az etanolban szuszpendált mintákat mikroszkópos tárgylemezre csepegtettük és száradást követően röntgen diffrakcióval vizsgáltuk. A diffraktogramon három éles reflexió jelent meg $2 \theta=43,3,50,4$ és 74,2 fokoknál (5.16. A ábra), amelyeket rendre a lapcentrált köbös rendszerben kristályosodó réz (111), (200) és (220) kristálylapjaihoz tartozó reflexióként azonosítottunk.

A röntgen diffraktogramok reflexióit Lorentz-görbével illesztettük és meghatároztuk az egyes reflexiókhoz tartozó $2 \theta$ értéket. A Bragg egyenlet (3. egyenlet) segítségével meghatároztuk a kristály rácssíkjainak távolságát (d). Ezt követően a d értékeket az 1/M $\left(M=\sqrt{h^{2}+\mathrm{k}^{2}+\mathrm{l}^{2}}\right.$, ahol h, $\mathrm{k}$ és 1 a Miller-indexek) függvényében ábrázoltuk (5.16. B ábra), amelyre egyenest illesztettünk. Az egyenes egyenletének meredekségéből kaptuk a rácsállandót.

$$
d=\frac{\mathrm{n} \lambda}{2 \sin \theta}
$$

3. egyenlet: Bragg egyenlet, ahol $n$ az elhajlás rendje, $\lambda$ a röntgensugár hullámhossza és $\theta$ a Bragg-szög.

Ehhez hasonlóan az elektrondiffrakciós felvételekből is meghatároztuk a rácsállandót. $\mathrm{Az}$ elektrondiffrakciós felvételen mért $\mathrm{R}$ távolságokból meghatároztuk a d értékeket (4. egyenlet), amelyeket összehasonlítva a JPCDS-adatlapokon lévő d értékekkel meghatároztuk a hozzájuk tartozó hkl indexeket. Ezután a fentebb említett módon ábrázoltuk a d értékeket és az illesztést követően megkaptuk a rácsállandót ${ }^{217}$. Ebben az esetben valamivel nagyobb értéket kaptunk $(3,709 \AA)$.

$$
R_{h k l}=\frac{\mathrm{L} \lambda \sqrt{\mathrm{h}^{2}+\mathrm{k}^{2}+\mathrm{l}^{2}}}{a}
$$

\section{4. egyenlet: Rácsállandó meghatározása elektrondiffrakciós felvételből, ahol az $L$ a kamerahossz, $L \lambda$ a} mikroszkópállandó és $\lambda$ az elektronsugár hullámhossza, $R$ filmen mért távolság.

A röntgendiffrakciós mérések alapján meghatározott rácsállandó a=3,619 A, amely szinte teljes egyezést mutat az irodalombeli a=3,615 $\AA-\mathrm{mel}^{122}$. A röntgendiffraktogramon semmilyen egyéb reflexió nem jelent meg, amely esetleges szennyezőanyag(ok)ra vagy CuO-ra utalna. A réz nanoszálak színe a levegőn való hosszabb idejủ tárolás következtében szürkés-feketére változott. Abban az esetben, ha a nanoszálakat etanol vagy hexán alatt tároltuk, ez a folyamat nem következett be. Az elszürkült mintáról készített röntgendiffraktogramon (5.16. A ábra) egy kisintenzitású reflexió jelent meg $36,5^{\circ}$-nál, amely 
az oxidatív atmoszféra következtében kialakult $\mathrm{Cu}_{2} \mathrm{O}$ réteg (111) kristálylapjának reflexiója. Feltételezhetően a $\mathrm{Cu}_{2} \mathrm{O}$ réteg már a vízzel való mosás során jelenlévő oldott oxigén hatására kialakul a nanoszálak felületén. Az XRD reflexiók alapján elmondható, hogy a nanoszálakat fémes állapotú réz alkotja, amelyeken oxigénnek való érintkezés útján $\mathrm{Cu}(\mathrm{I})$ oxid réteg alakul ki.
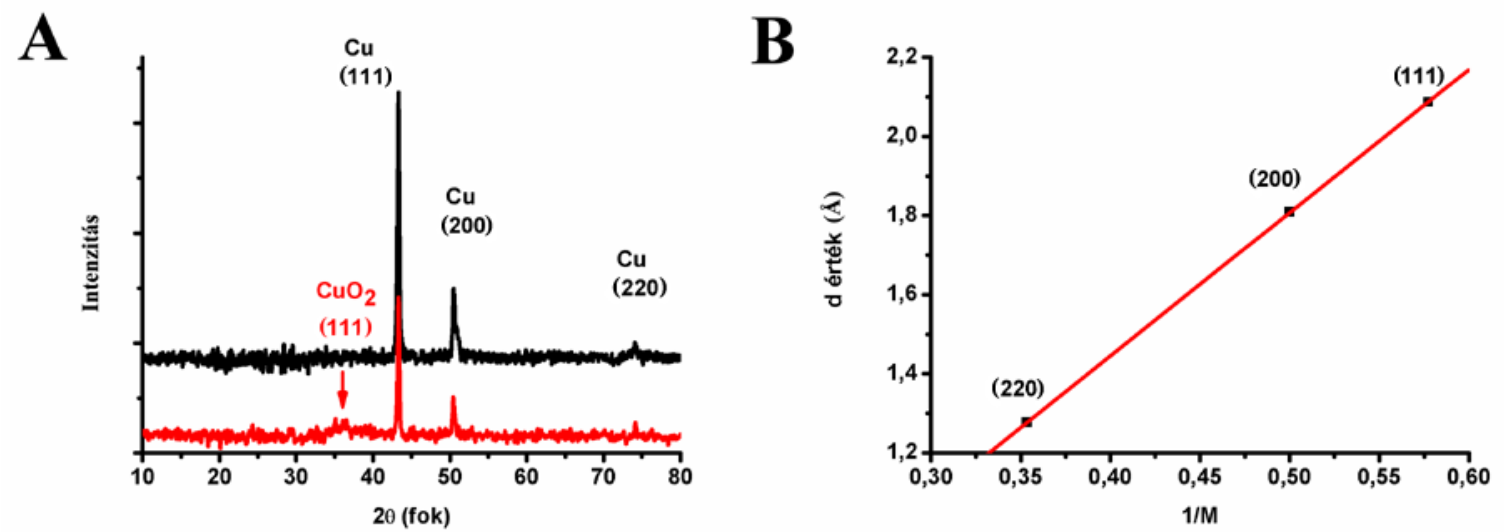

5.16. ábra: (A) Eredeti és az oxidálódott réz nanoszál röntgendiffraktogramja és (B) az „a” rácsállandó meghatározása.

\subsubsection{Növekedési mechanizmus}

A növekedési mechanizmus, valamint a védőmolekula (HDA) és a glükóz a réz nanoszálak morfológiájának kialakulásában betöltött szerepének feltárása érdekében különböző mólarányban adagoltuk a HDA-t és a redukálószert a réz-klorid oldathoz. A Cu-só és a víz mennyiségét változatlanul tartottuk.

\subsubsection{D-glükóz/réz mólarány hatása a nanoszálak képzödésére}

Amennyiben 2:1 glükóz/réz mólarányt alkalmaztunk, többnyire nanoszálak képződtek (5.17. B ábra). Ebben a termékben csak elvétve voltak egyéb morfológiájú részecskék. Azonban ha az arányt 3-4-szeresére növeltük, akkor egyre több változatos morfológiájú és méretü nanorészecskét találtunk a SEM felvételeken (5.17. C és D ábra). A glükóz/réz 4:1 mólarány esetén 50-300 nm-ig terjedő nanorészecskékből álló terméket kaptunk, amelyben csak elvétve találtunk nanoszálakat.

Következésképpen nagy glükózkoncentráció mellett csak kevés góc aktív a nanoszál növekedés szempontjából. A glükóz mennyiségének drasztikus csökkentése esetén szinte kizárólag nanoszálakat kaptunk. Ebben az esetben a termék egy világoskék szuszpenzió, 
amelynek az alján ülepedett ki a vörösesbarna réz nanoszálakat tartalmazó csapadék. Ez arra enged következtetni, hogy a réznek csak egy töredéke redukálódott az elöállítás során. A SEM felvétel alapján nyilvánvaló, hogy ezek a nanoszálak kristályhibákat tartalmaznak (5.17. A ábra).
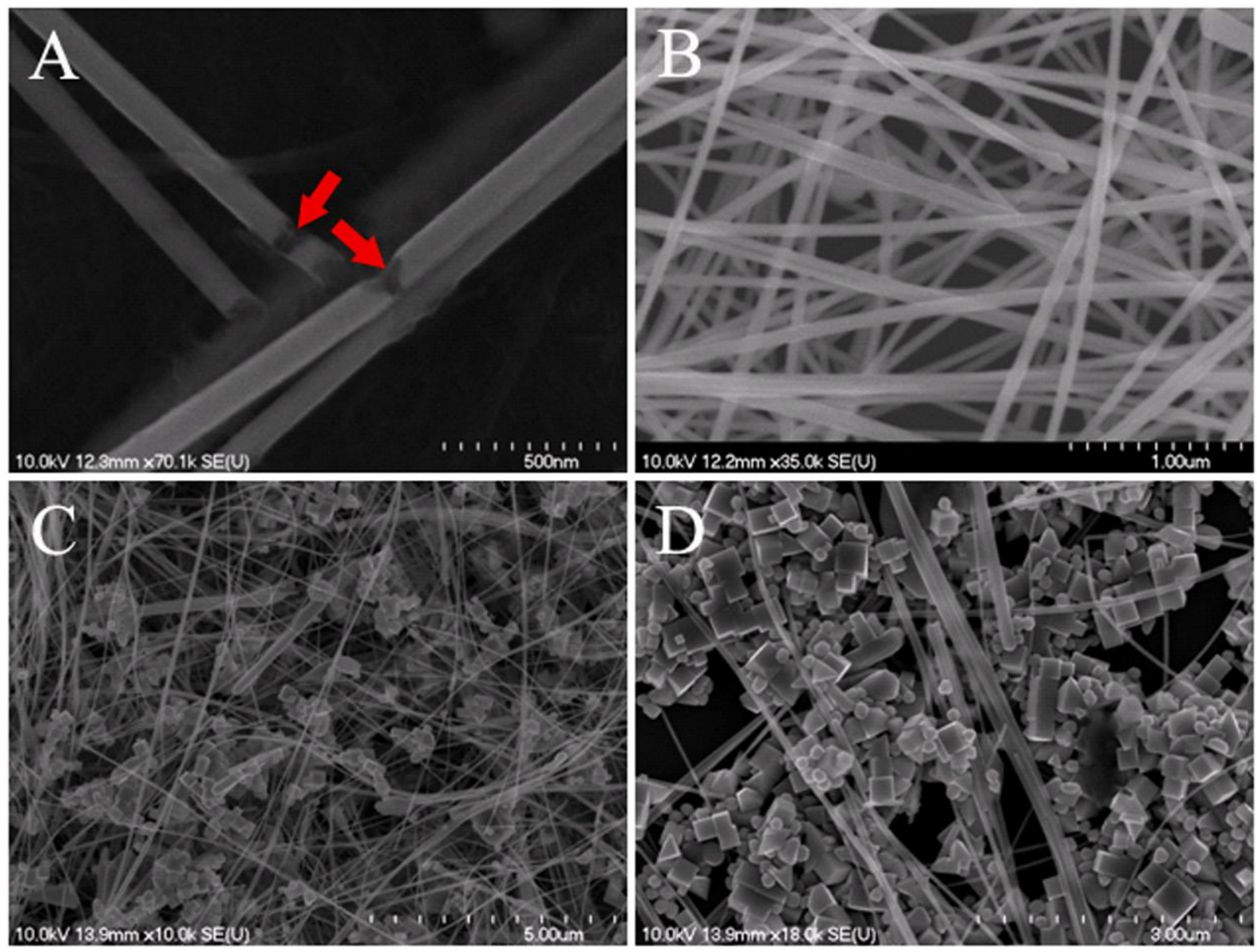

5.17. ábra: D-glükóz/réz mólarány hatása a nanoszálak képződésére: SEM felvételek (A) 0,2:1, (B) 1:1, (C) 3:1, and (D) 4:1 arányok esetén.

\subsubsection{1-hexadecil-amin/réz mólarány hatása a nanoszálak képzödésére}

A HDA:réz mólarány szintén egy olyan tényezőnek tekinthető, amely jelentősen befolyásolja a nanoszálak morfológiáját és hossz/átmérő arányát. Az 5.18. ábrán különböző HDA mennyiségek jelenlétében (3,0 mmol, 4,5 mmol, 7,5 mmol és 9,0 mmol) készített minták SEM felvételei láthatók. Nagy HDA koncentráció túl nagy felületi borítottságot eredményez, míg ellenkező esetben a kis mennyiségű HDA nem képes megfelelően passziválni a kristálylapokat ${ }^{52}$. Mindkét eset izotróp növekedést eredményez. 

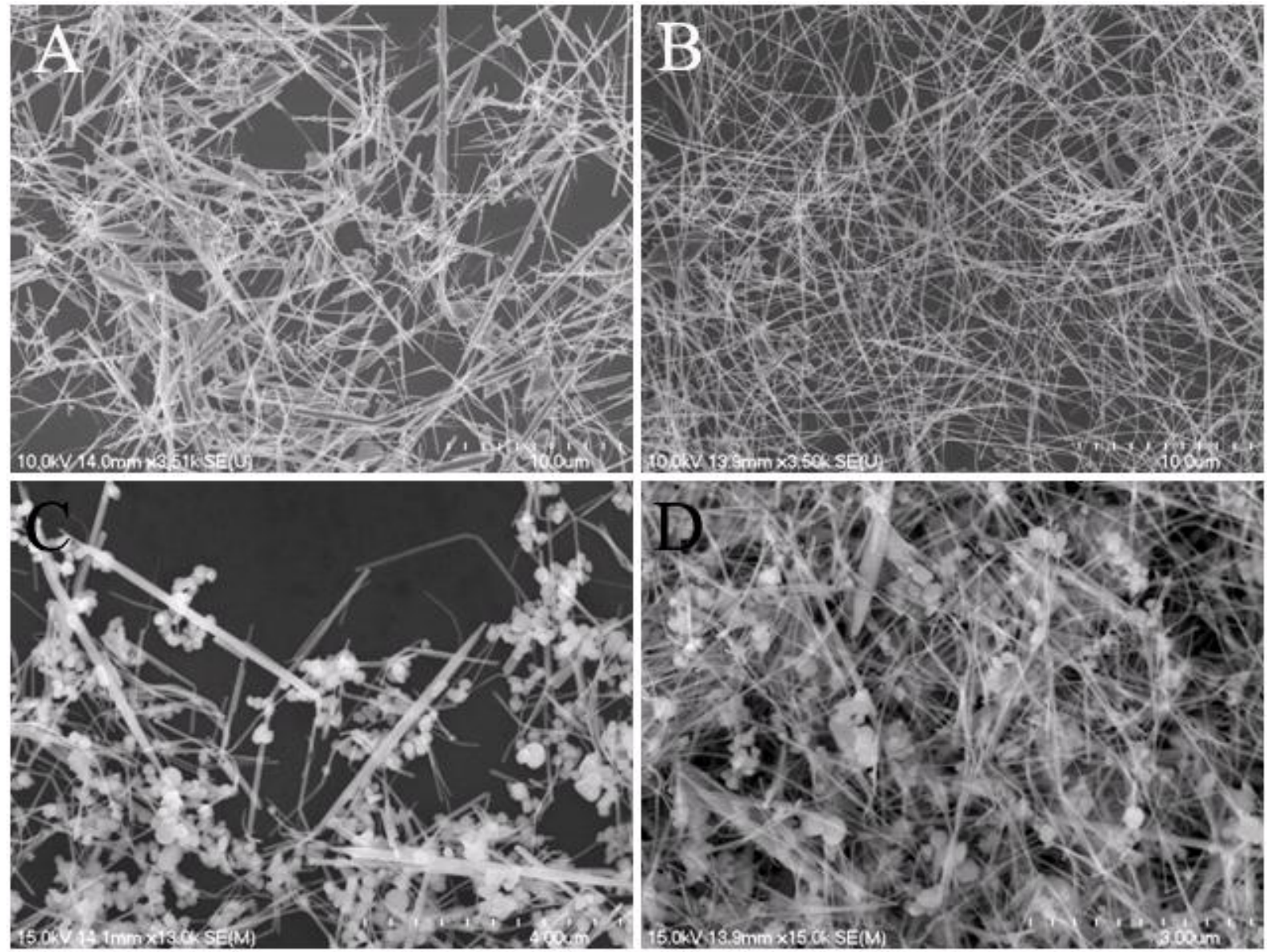

5.18. ábra: Különböző HDA mennyiségek jelenlétében előállított minták SEM felvételei: (A) 3,0 mmol, (B) 4,5 mmol, (C) 7,5 mmol és (D) 9,0 mmol.

\subsubsection{A nanoszálak növekedésének vizsgálata az idö függvényében}

A nanoszálak növekedési mechanizmusának megismerése érdekében a hidrotermális szintézist eltérő időtartamok mellett is elvégeztük. Így megismerhettük a nanoszálak növekedési kinetikáját. A termékeket SEM, TEM és XRD módszerekkel jellemeztük. A $120{ }^{\circ} \mathrm{C}$-on végzett szintézisek többnyire hasonló nanoszálakat eredményeztek 6-72 órás időtartamok alatt (5.20. E és F ábra).

\subsubsection{A feltételezett növekedési mechanizmus}

Xia és munkatársai szerint a végleges morfológia kialakításában kulcskérdés a kialakuló gócok kristályszerkezete a nukleációs lépésben és az azt követő növekedési fázisban ${ }^{105}$. A 5.19. ábra a különböző időtartamú hidrotermális kezelést követően kialakult termékeket mutatja be. A réz nanoszálak szuszpenziója 1-2 óra elteltével zöldeskék színű volt 
(5.19. Dábra). Hosszabb idejü hidrotermális kezelést követően vörösesbarna szuszpenziót kaptunk (5.19. E, F és G ábra).

Az 5.20. ábrán a különböző időtartamú hidrotermális kezelésen átesett minták TEM felvételei láthatóak. Az 1 órás szintézist követően a minta legnagyobb részt 2,1 7 nm-es nanorészecskékből állt és nanoszálakat nem tartalmazott (5.20. A ábra). Ebben a korai fázisban a HDA nagy lapokban jelent meg. Ugyanakkor a 2 és 3 órás kezelést követően megjelennek nanoszálak is a mintában (5.20. B, C és D ábra), valamint a HDA feltekeredett állapotban látható ${ }^{142,218,219}$. A 6 órás kezelés után a minta többnyire csak nanoszálakat tartalmazott (5.20. Eábra).

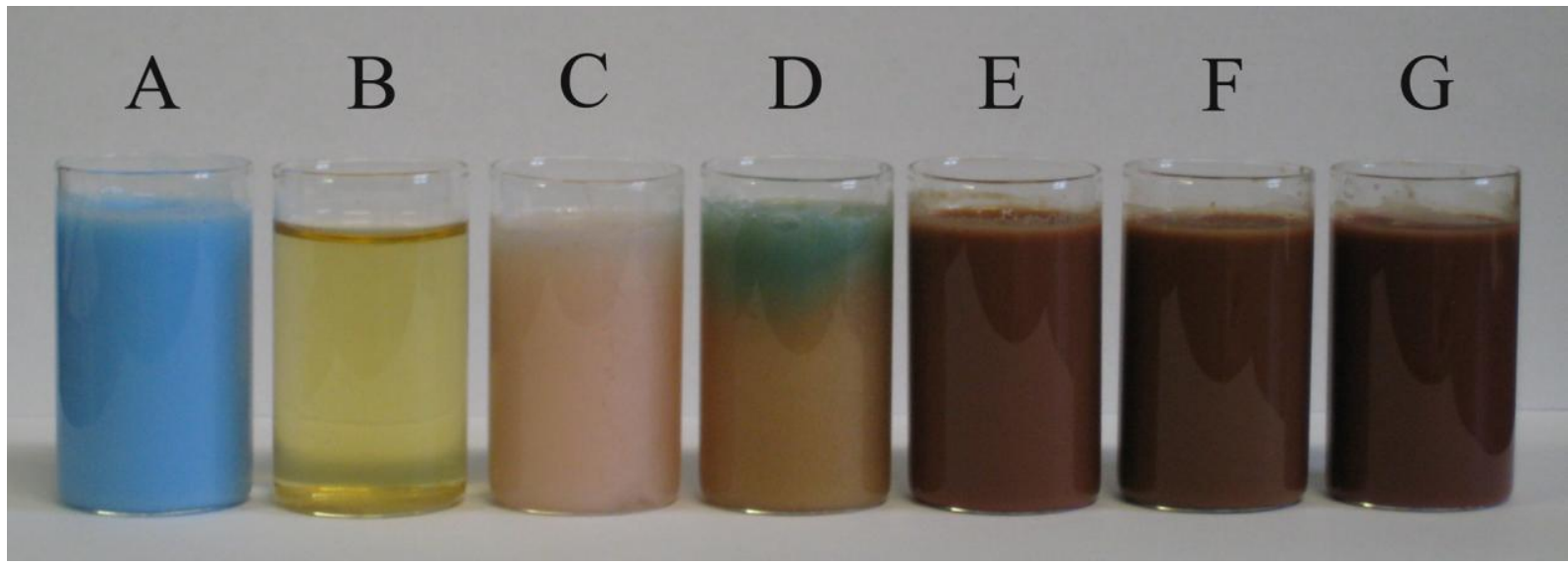

5.19. ábra: Különböző reakcióelegyek fényképfelvétele. (A) réz szuszpenzió a hidrotermális kezelést megelőzően, (B) 24 órás hidrotermális kezelés HDA jelenléte nélkül, $(C) 24$ órás hidrotermális kezelés glükóz hiányában. D, E, F és G minták 1, 3, 6 és 24 órás hidrotermális kezelés eredményei.

A megfigyeléseink alapján a réz nanoszálak növekedése a korai szakaszban megjelenő réz nanokristályokból indul ki, melyek az ED mérések alapján feltételezhetően egykristályosak. A HDA létfontosságú szerepet tölt be a gócképződésben. HDA, illetve glükóz hiányában készített minták színét az 5.19. ábra mutatja be. A minták színe arra utal, hogy ezekben az esetekben nem képződtek réz nanoszálak, és ezt megerösítették az elektronmikroszkópos vizsgálatok is. A HDA hiányában egy halványsárga szuszpenziót kaptunk, amelyből megközelítőleg egy nap múlva fehér csapadék ülepedett ki, amely méréseink alapján réz-oxid.

A glükóz jelenléte a szintézis során szintén elengedhetetlennek bizonyult. A glükóz felelős a gócok kialakulásáért a szintézis korai szakaszában, amelyekből a folyamat előrehaladtával a nanoszálak nőnek. Nanoszálak nem voltak azonosíthatóak ebben a mintában sem. 

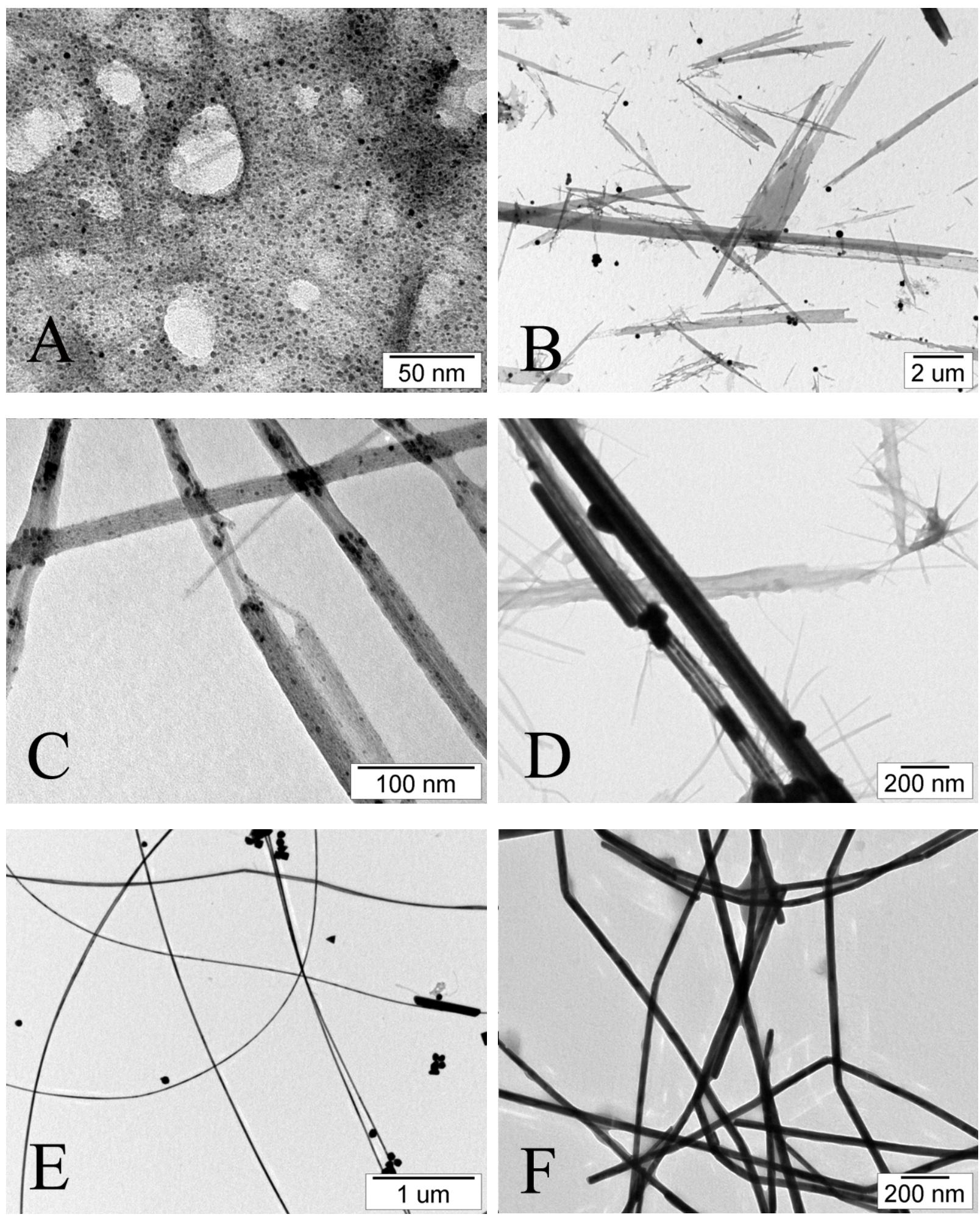

5.20. ábra: A eltérő időtartamú hidrotermális kezelés hatására kialakult termékek: (A) 1 h, (B) 2 h, (C és D) $3 \mathrm{~h}$, (E) 6 h, és (F) $24 \mathrm{~h}$. 
A SEM felvételek igazolták, hogy a HDA a nanoszál köré tekredve beburkolja azt (5.21. ábra). A becsomagolt nanoszál teljes átmérője $214 \pm 39 \mathrm{~nm}(5.22$. A ábra), míg a rézszál (5.22. B ábra) maga $31 \pm 7$ nm-es.
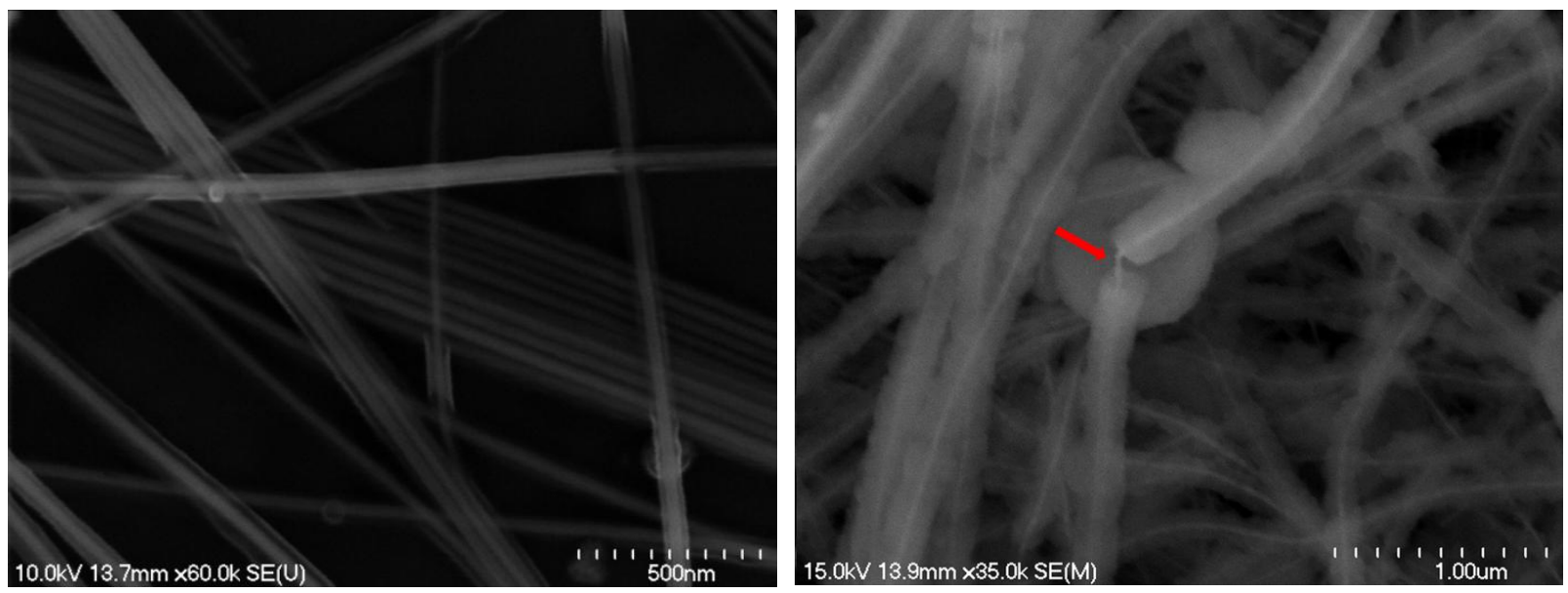

5.21. ábra: HDA burkolat a nanoszálak körül.

Az általunk kifejlesztett módszerben a HDA szerepe hasonló a Liu és munkatársai által kifejlesztett komplex hidrotermális módszerben ${ }^{122}$ található SDBS szerepéhez, amely a korai szakaszban megakadályozza a gócként funkcionáló nanorészecskék agglomerációját.

A

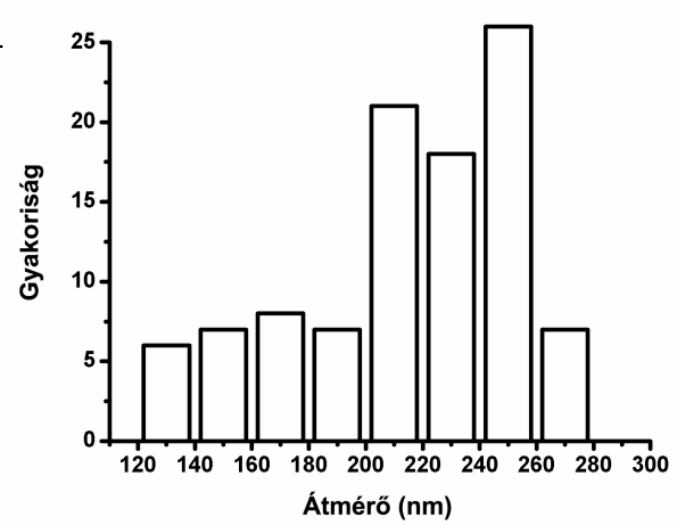

B

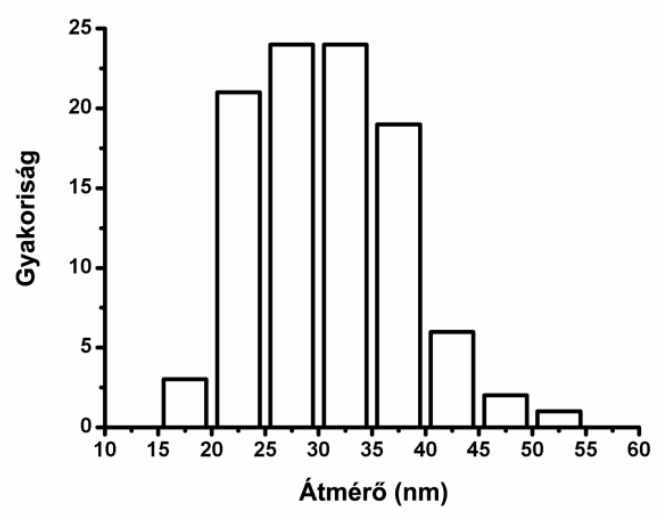

5.22. ábra: (A) A HDA burkolt szál átmérőinek, illetve (B) a burkolatban lévő szálak átmérőinek méreteloszlási hisztogramjai.

Annak ellenére, hogy az elektrondiffrakció egykristályos mintázatot mutatott, a nanoszálak helyenként szögletes elfordulásokat tartalmaznak. Ez a látszólagos ellentmondás jól magyarázható a 3 órás (5.20. C és D ábra) mintánál megjelenő nanoszál „kompozitok” megjelenésével, amelyeket nanorészecskék adhéziójából álló mikrométeres nanokristályok 
alkotnak. Néhány szintézis termékében érdekes nanoszál képződményeket, „pöttyös nanoszálakat" fedeztünk fel (5.23. ábra). Két kialakulási mechanizmust tartunk lehetségesnek. Az első elmélet szerint a nanoszálak és a nanorészecskék képződése egy kompetitív folyamat, amelyben az aggregáció és az átkristályosodási reakciók egy komplex felszín kialakulásához vezetnek. A másik elmélet szerint a nanoszálak növekedésekor a szál hosszanti tengelye mentén a koncentráció nem egységes, amely lokális kristálynövekedéseket eredményez eltérő kristálylapok mentén.

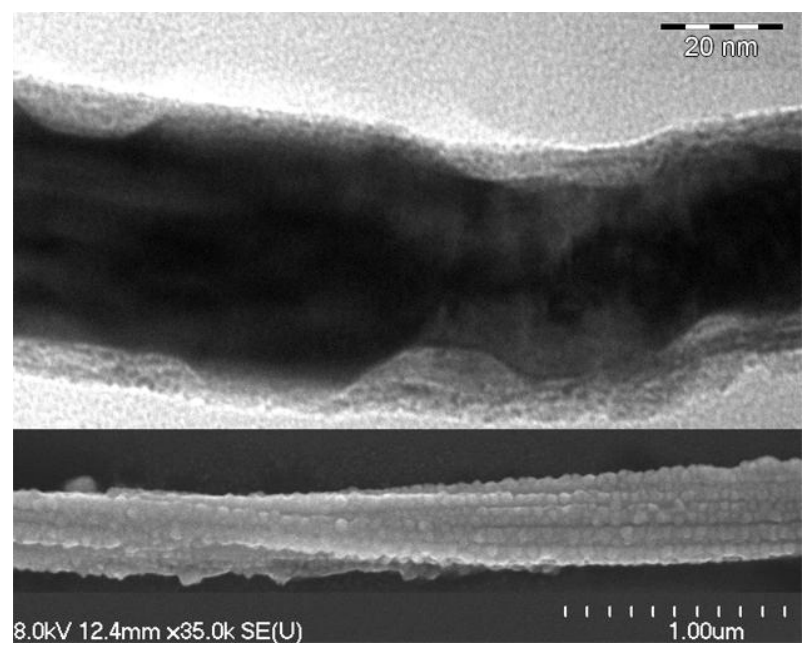

5.23. ábra: A „pöttyös nanoszálak" TEM (felül) és SEM felvétele (alul).

\subsubsection{Különböző rézsókkal végzett kísérletek}

Kísérleteink során vizsgáltuk a kiindulási rézsó anionjának a végtermékre gyakorolt hatását. A kísérleti paramétereket és a kiindulási szuszpenzió összetételét fixen tartva, elvégeztük a kísérletet réz-nitrátból és réz-acetátból kiindulva. A szuszpenzió elkészítésekor felfigyeltünk arra, hogy annak színe a megszokott halványkék helyett enyhén lila, illetve erősen lila színű volt. Ez az eltérés a színben az eredeti recept során kialakuló $\mathrm{Cu}^{2+}$ komplexektől eltérő komplexek kialakulásának a következménye. A SEM felvételek azonban rávilágítottak arra, hogy a termékek morfológiájában is jelentős volt az eltérés a hidrotermális kezelést és a tisztítást követően (5.24. ábra). Mindkét esetben 100 nm-t meghaladó mérettel rendelkező részecskék keletkeztek.

Ezzel a kísérlettel nyilvánvalóvá vált, hogy a kloridionok jelentős szerepet töltenek be a nanoszálak kialakulásában, valamint, hogy a HDA önmagában nem biztosítja az 1D szerkezet kialakulását. 
Miután fény derült arra, hogy az eltérő kiindulási rézsókkal (réz-klorid, réz-acetát, réznitrát) végzett kísérletek során kizárólag a réz-klorid esetében kaptunk nanoszálakat, egyértelművé vált, hogy a kloridionok elengedhetetlen szereplői a réz nanoszálak előállításának. Vizsgálni kezdtük tehát a $\mathrm{NaCl}$ és $\mathrm{NaBr}$ hatására a részecskemorfológiában bekövetkező változásokat. A reakció egyéb paramétereit állandóan tartva eltérő mennyiségben adagoltunk $\mathrm{NaCl}$-ot és $\mathrm{NaBr}$-ot a szuszpenzióhoz.
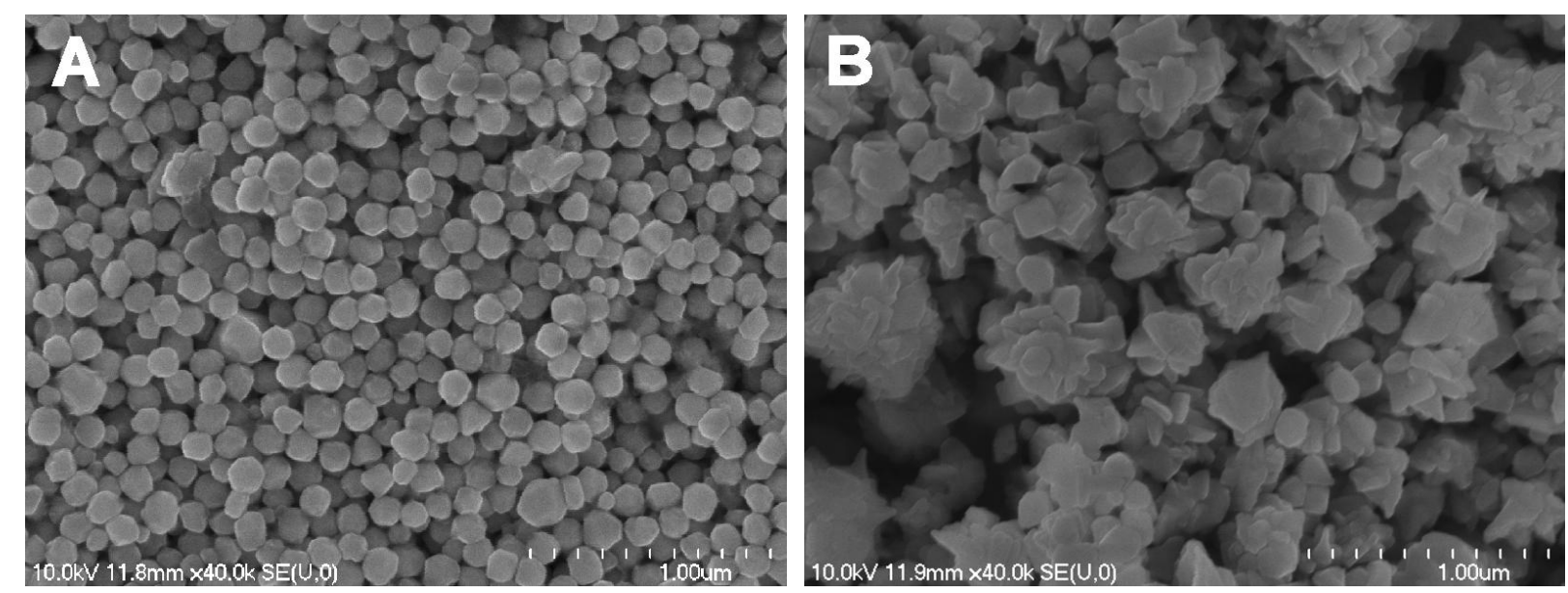

5.24. ábra: Eltérő fémsókkal előállított minták SEM felvételei: (A) réz-acetát, $(B)$ réz-nitrát.

\subsubsection{Klorid- és bromidionok hatása a végtermék morfológiájára}

A réz-nitráttal, illetve réz-acetáttal elkészített szuszpenziókhoz $0,0,5,1,0,1,5$, 4,0 stb. mmol mennyiségekben NaCl-ot adagoltunk keverés közben. Minél több NaCl-t adtunk a rendszerhez, annál világosabb kékes színt tapasztaltunk. A kék szín nyilvánvalóan a $\mathrm{Cu}^{2+}$-ion klorokomplexeinek köszönhető.

A végtermékekről készült SEM felvételeken (5.25. ábra) jól látható, hogy $1 \mathrm{mmol}$ $\mathrm{NaCl}$ adagolás hatására, ugyan kis számban, de már megjelennek hosszúkás részecskék is a végtermékben. A NaCl mennyiségét tovább emelve 4 mmol-nál már szinte csak egydimenziós részecskék láthatóak. $\mathrm{A} \mathrm{NaCl}$ további emelése nem eredményez változást a réz nanoszerkezetek morfológiájában.

$\mathrm{Az}$ előállított mintákon röntgendiffrakciós vizsgálatokat végeztünk. A diffraktogramokon (5.26. ábra) szinte kizárólag az fcc kristályszerkezettel rendelkező réz (111), (200), (220) kristálylapok reflexiói jelentek meg. Kivételt képez ez alól a NaCl-mentes, 
réz-nitrátos minta, amely esetében megjelentek a $\mathrm{Cu}_{2} \mathrm{O}$ jelenlétére utaló (110), (111), (200), (220) és (311) kristálylapokhoz tartozó reflexiók is.
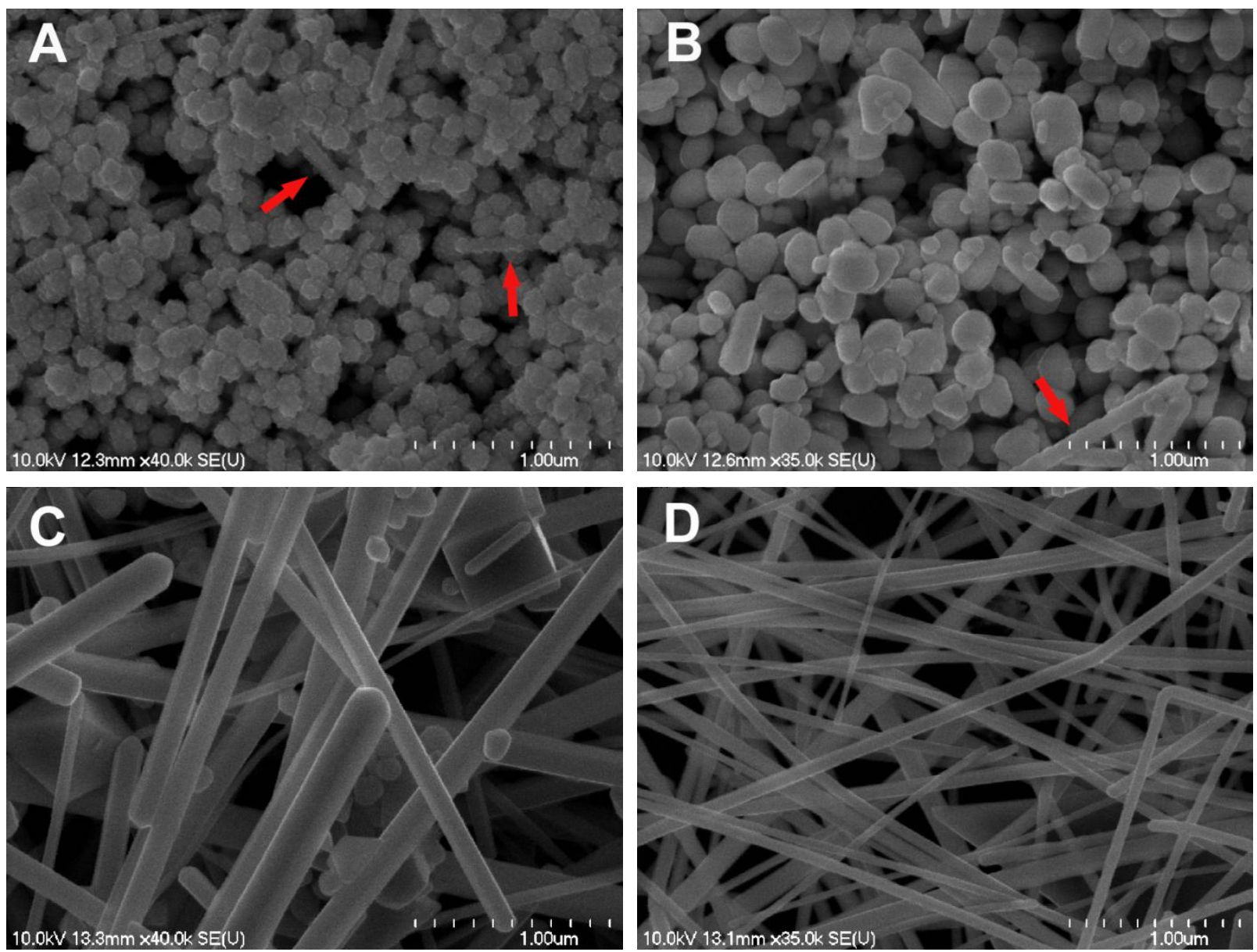

5.25. ábra: SEM felvételek: (A) réz-acetát $1 \mathrm{mmol} \mathrm{NaCl,} \mathrm{(B)} \mathrm{réz-nitrát} 1 \mathrm{mmol} \mathrm{NaCl},(\mathrm{C})$ réz-acetát 4 mmol $\mathrm{NaCl}$ és (D) réz-nitrát $4 \mathrm{mmol} \mathrm{NaCl}$.

A fent említetthez hasonlóan $\mathrm{NaBr}$ adagolással is elvégeztük a kísérleteket. Ebben az esetben 1,0 mmol NaBr hatására már megjelentek anizotróp, egydimenziós nanoszerkezetek. Ugyanakkor a nanoszálak mellett három-, illetve többszögletű lapos képződményeket is tartalmazott a minta, igen nagy mennyiségben. Az elektronmikroszkópos felvételeken megfigyelhető, hogy a bromidionok mennyiségének növelésével a nanoszálak képződése visszaszorul, és ezzel párhuzamosan egyre nagyobb méretü táblaszerü képződmények alakulnak ki (5.27. ábra). 


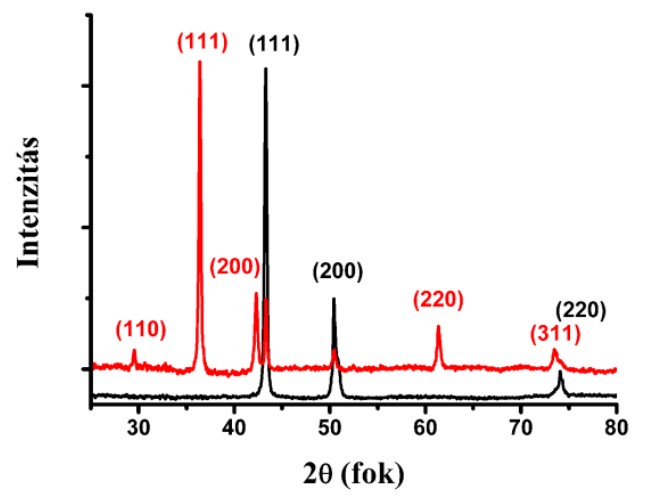

5.26. ábra: Röntgen diffraktogramok (piros) sima réz-nitrátos minta, (fekete) egyéb minták.

Több kutatás is irányult már a nanokristályok alakját befolyásoló ionok és molekulák feltárására. Poliol módszerrel előállított ezüst nanoszerkezetek esetében már megfigyeltek hasonló jelenséget ${ }^{105}$.
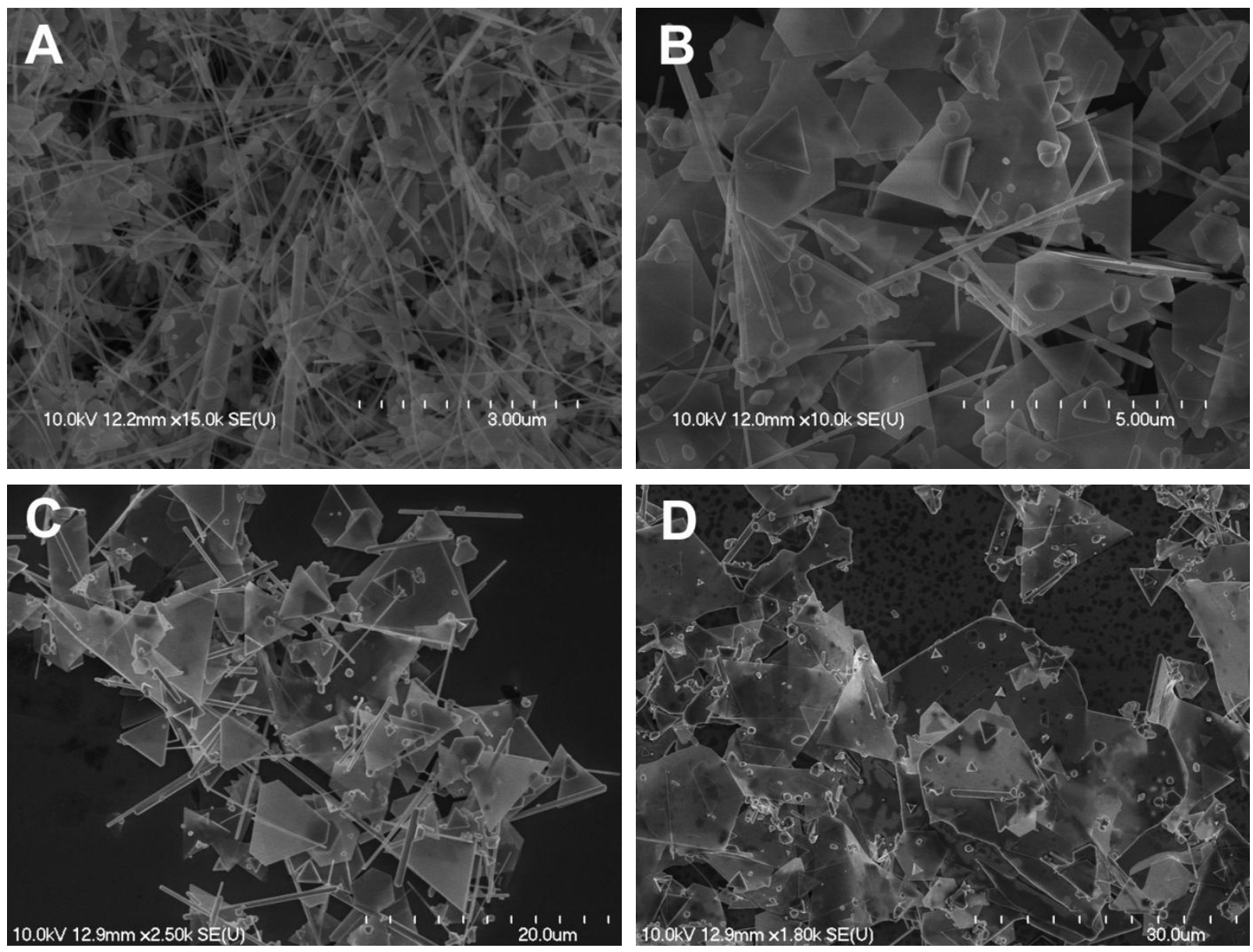

5.27. ábra: SEM felvételek: (A) réz-acetát $1 \mathrm{mmol} \mathrm{NaBr,} \mathrm{(B)} \mathrm{réz-nitrát} 1 \mathrm{mmol} \mathrm{NaBr}$, (C) réz-acetát $4 \mathrm{mmol} \mathrm{NaBr}$ és (D) réz-nitrát $4 \mathrm{mmol} \mathrm{NaBr}$. 
Kloridionok és $\mathrm{O}_{2}$ is jelen van a szuszpenzióban, melyek jelenléte erős oxidatív hatást gyakorol az ikerkristályos kristálygócokra és kristálymagokra. Miután a kloridion erősen korrozív, ezért valószínűleg csak egykristályos kristálymagok maradnak fenn az oldatban.

A bromidion valamivel gyengébben korrozív, ezért az egykristályok mellett ikerkristályos kristálygócok is „túlélnek”, amelynek köszönhetően többféle morfológiájú terméket kaptunk. A bromidionok jelenlétében megjelenő táblaszerü képződmények rétegződési hibákra utalhatnak. Helyenként megjelennek az 1D nanoszerkezetek is a mintában, viszont mennyiségük lényegesen kevesebb, mint a $\mathrm{NaCl}$ jelenlétében előállított mintákban.

\subsubsection{Elektromos mérések}

Réz nanoszálak oxido-redukciós vizsgálata

A nanoszálakat különböző hőkezeléseknek tettük ki eltérö gázatmoszférákban $\left(\mathrm{N}_{2}\right.$, levegö és $\left.\mathrm{H}_{2} / \mathrm{Ar}\right)$. Már viszonylag alacsony hőmérsékleten, $550 \mathrm{~K}\left(277^{\circ} \mathrm{C}\right)$ klaszterek képződése volt megfigyelhető a nanoszálak felszínén.

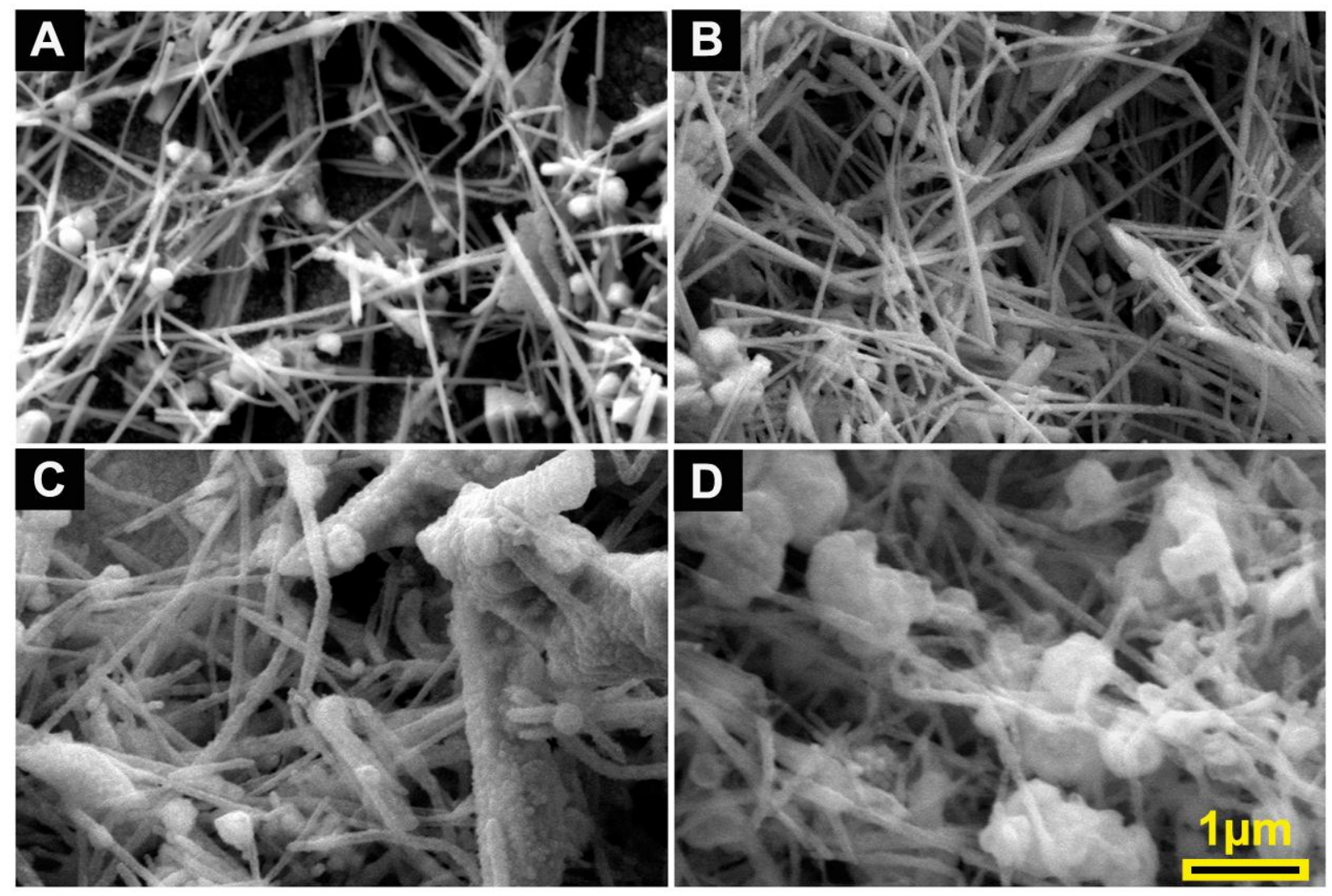

5.28. ábra: Klaszterképződés nyomon követése a kezelések során. (A) eredeti minta a kezelés előtt, (B) 5\% $\mathrm{H}_{2}$ /Ar atmoszférában történő kezelést követően, (C) szintetikus levegőben $6 \mathrm{~K} /$ perc fütési/hütési sebességgel való kezelés után: $300 \mathrm{~K} \rightarrow 550 \mathrm{~K} \rightarrow 350 \mathrm{~K} \rightarrow 550 \mathrm{~K} \rightarrow 300 \mathrm{~K}$. (D) számos hőciklusnak kitett minta $625 \mathrm{~K}$-ig levegőben és $1000 \mathrm{ppm} \mathrm{H}_{2} / \mathrm{Ar}$ atmoszférában. 
Feltételezhetően a nanoszálak felületén visszamaradt HDA vagy egyéb szennyezőanyag olvad meg és kristályosodik át a hőmérsékleti ciklusok alatt. A szintetikus levegő atmoszférában fütött minták oxidálódtak, amit a SEM és EDS mérések is igazolnak. A hőmérsékleti ciklusokkal egybekötött redoxi kezelések során oxidációkor az ellenállás jelentős megnövekedése, redukciókor annak csökkenése volt megfigyelhető.

A klaszterek képződését SEM felvételeken az 5.28. ábra mutatja be. Az 5.28. A ábra (A minta) kezelés előtti réz nanoszálakat mutatja, az 5.28. B ábra (B minta) az 5\% $\mathrm{H}_{2}$ /argonatmoszférában kezelt és az 5.28. $C$ ábra ( $C$ minta $)$ a oxigén atmoszférában $6 \mathrm{~K} /$ perc felfütési sebességgel, a következő hőmérsékleti ciklusoknak kitett mintát mutatja be: $300 \mathrm{~K} \rightarrow 550 \mathrm{~K}$ $\rightarrow 350 \mathrm{~K} \rightarrow 550 \mathrm{~K} \rightarrow 300 \mathrm{~K}$. A $D$ mintát számos fütési ciklusnak vetettük alá $625 \mathrm{~K}\left(352{ }^{\circ} \mathrm{C}\right)$ levegő és 1000 ppm $\mathrm{H}_{2}$ argonatmoszférában. Habár néhány klaszter megfigyelhető az $A$ mintában is, de a $B\left(550 \mathrm{~K}\right.$-en $\mathrm{H}_{2}$-atmoszférában kezelt) és $C(550 \mathrm{~K}$-en levegőn kezelt) mintákban jóval intenzívebb a klaszterek képződése. A legnagyobb mértékű klaszterképződés a $D$ minta esetén figyelhető meg, amit hidrogénben és levegőben több cikluson keresztül $625 \mathrm{~K}-\mathrm{re}\left(352^{\circ} \mathrm{C}-\mathrm{ra}\right)$ fütöttünk fel.

Az EDS mérésekből származó $\mathrm{Cu} / \mathrm{O}$ atom arányokat az 5.3. táblázat mutatja be. A mérésekből nyilvánvalóvá vált, hogy az A minta csak kismértékben tartalmaz oxigént, ami feltételezhetően a nanoszálakon lévő $\mathrm{Cu}_{2} \mathrm{O}$ rétegből származik. A $B$ minta oxigéntartalma szintén származhat a felületi réz(I)-oxid rétegből. A levegőn kezelt $C$ mintában kimutatott nagymennyiségü oxigén a réz nanoszálak oxidálódására utal. A SEM felvételen megfigyelhető, hogy a $C$ mintában jóval nagyobb, rücskös felszínü klaszterek vannak, mint a $B$ mintában.

\begin{tabular}{l|c|c} 
& Cu & 0 \\
\hline A minta & 8,4 & 1 \\
B minta & 9,7 & 1 \\
C minta & 3,3 & 1 \\
D minta & 1,2 & 1
\end{tabular}

\section{3. táblázat: $\mathrm{Cu} / \mathrm{O}$ atom arányok az EDS mérések alapján.}


Ez a megfigyelés összhangban áll azzal az elmélettel, hogy a nanoszálak felületén oxidréteg képződik, amely révén a kristályrács kitágul és a nanoszálak klaszterekké „olvadnak” össze.

A $D$ mintát magasabb és hosszabb idejü hőkezelésnek vetettük alá oxidatív és reduktív atmoszférában. Ebben a mintában találhatóak a legnagyobb klaszterek, amelyek növekedését a magasabb hőmérséklet és hosszabb idejü kezelés okoz. A $\mathrm{Cu} / \mathrm{O}$ atom arány ebben az esetben 6:5. Az oxigéntartalom nagyon magas ahhoz képest, hogy az utolsó ciklusban reduktív atmoszférát $\left(1000\right.$ ppm $\left.\mathrm{H}_{2}\right)$ alkalmaztunk. Következésképpen az intenzív klaszterképződés gátolja a nanoszálak redukcióját.

Nyilvánvaló, hogy már viszonylag alacsony hőmérsékleten $\left(550 \mathrm{~K}, 277^{\circ} \mathrm{C}\right)$ klaszterek képződnek a mintában. A klaszterek kialakulásáért és növekedéséért kétféle mechanizmust tartunk felelösnek:

(i) A nanoszálak felszínén valamilyen szennyezőanyag marad vissza a szintézisből, amely megolvad és egyesül a hőkezelés folyamán. Lehetséges, hogy a minták felületén HDA vagy glükóz marad vissza az intenzív tisztítási lépés ellenére, amely felelős lehet a klaszterképződésért. Ez a valószínübb magyarázata a klaszterképződésnek.

(ii) A nanoszerkezetek esetében ismert az olvadáspont csökkenése ${ }^{12-14}$, amely szintén szerepet játszhat a folyamatban. Ezt az elméletet kevésbé tartjuk valószínünek.

\section{Az elektromos mérések eredményei}

A réz nanoszálakon mért I-V karakterisztika (5.29. A ábra) egyenes, függetlenül a gate feszültségtől, ami nem meglepő egy fémesen vezető anyag esetében. A minták nagyon érzékenyek az oxigén jelenlétére. Mint az az 5.29. B ábrán látható, a réz nanoszálak már $360 \mathrm{~K}\left(87^{\circ} \mathrm{C}\right)$ hőmérsékleten oxidálódnak a mintakamrában lévő inert atmoszférába került kismennyiségü levegő hatására. Látható, hogy ezen a hőmérsékleten a minta egy magasabb oxidációs állapotba kerül, ami az ellenállás nagymértékü emelkedésében mutatkozik meg. 

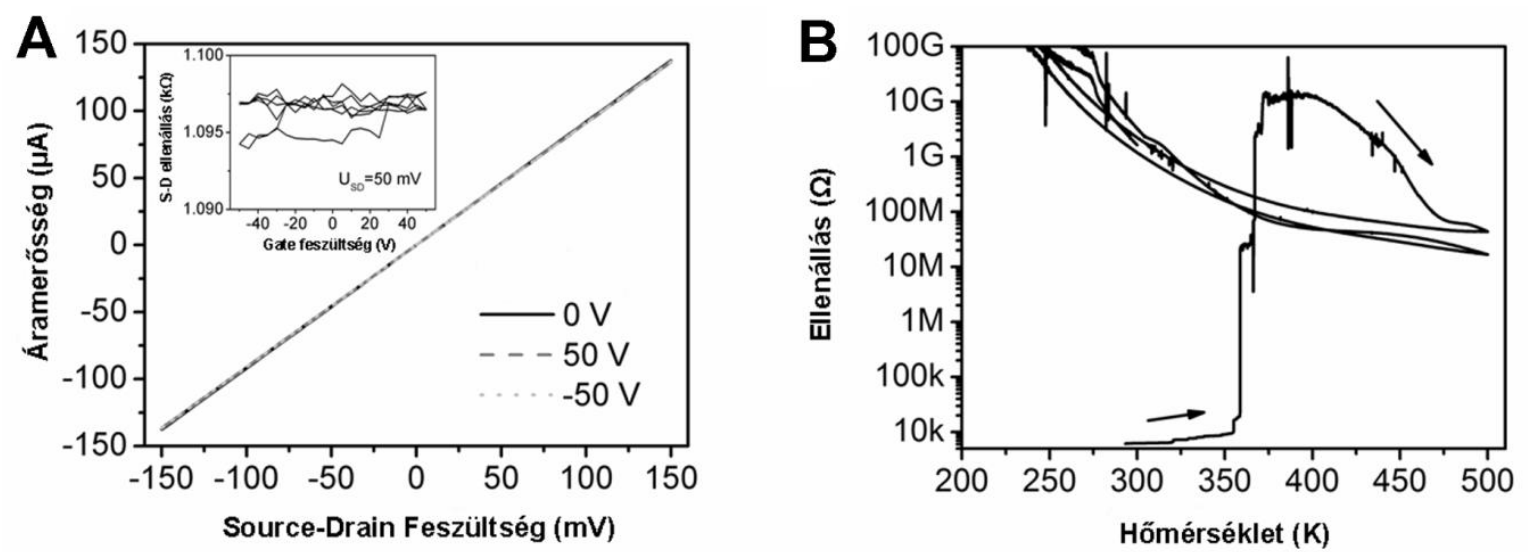

5.29. ábra: (A) I-V karakterisztika különböző gate (kapu) feszültségek mellett levegőn, a hő és gázkezeléseket megelőzően. A betétábra a source-drain (forrás-nyelö) ellenállást mutatja a gate feszültség függvényében, $50 \mathrm{mV}$ SD próbafeszültség mellett. (B) Ellenállás-hőmérséklet görbe nitrogénatmoszférában. Hőkezelés: $300 \mathrm{~K} \rightarrow 500 \mathrm{~K} \rightarrow 150 \mathrm{~K} \rightarrow 500 \mathrm{~K} \rightarrow 150 \mathrm{~K} \rightarrow 300 \mathrm{~K}$. (230 K alatt az alacsony áramerősség értékek miatt a mért ellenállásértékek meglehetősen pontatlanok.)

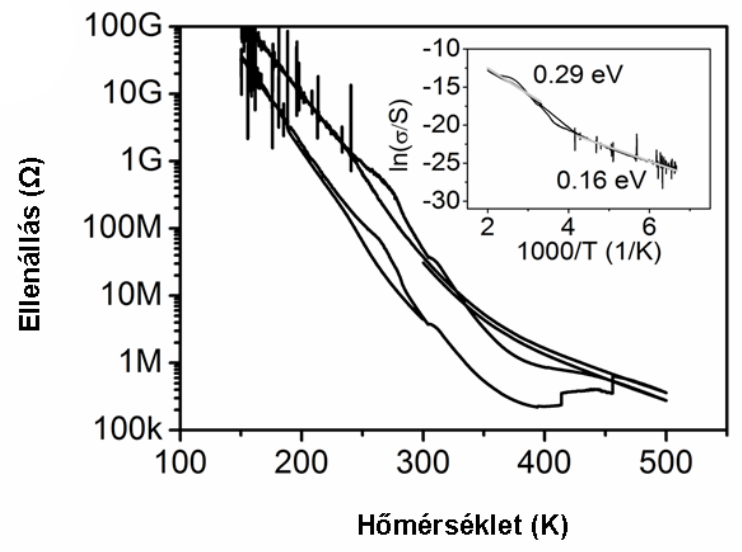

5.30. ábra: Nitrogénatmoszférában mért ellenállás-hőmérséklet görbék. Hőkezelés: $300 \mathrm{~K} \rightarrow 150 \mathrm{~K} \rightarrow$ $500 \mathrm{~K} \rightarrow 150 \mathrm{~K} \rightarrow 500 \mathrm{~K} \rightarrow 300 \mathrm{~K}$. Betétábra: Arrhenius görbe: 150-500 K hőmérséklet tartományban mért elektromos vezetőképesség.

A korábbi oxidációs állapot további hőkezelések hatására sem állt vissza. Az 5.30. ábra az oxidált minta ellenállásának exponenciális jellegü hőmérsékletfüggését mutatja nitrogénatmoszférában. Az Arrhenius diagramon (5.30. ábra betétábra) két energiagát azonosítható ( 0,16 és $0,29 \mathrm{eV}$ az alacsony és a magas hőmérséklettartományban), amely feltételezhetően réz-oxid és réz nanoszálak vagy a réz és a Pt elektródok érintkezésénél kialakuló Schottky kontakt eredménye. Ugyanakkor ezek mellett nem zárható ki a töltéshordozók koncentrációjának exponenciális jellegü hőmérsékletfüggésének szerepe sem, amely tipikusan jellemző a félvezető anyagokra. Singht és munkatársai megfigyelték, hogy a $\mathrm{Cu}$-Se nanoszálak rezonáns alagút diódaként (RTD) viselkednek ${ }^{220}$. 

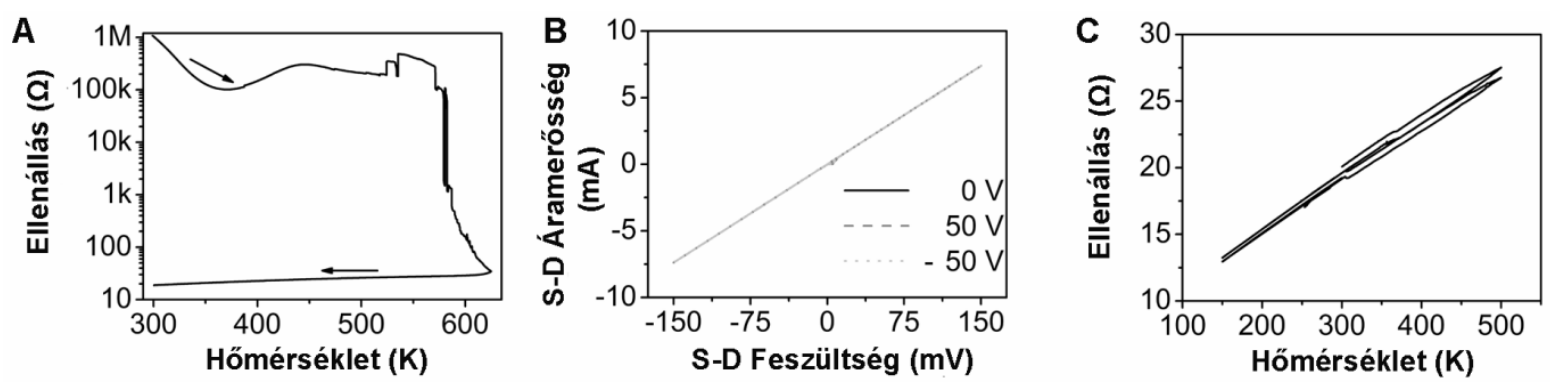

5.31. ábra: (A) Az ellenállás változása a nanoszál hálózat redukciós kísérlete során (1000 ppm $\mathrm{H}_{2}$ argonban). (B) Source-drain áram-feszültség görbék eltérő gate feszültségek mellett

levegőatmoszférában, a redukciós lépést követően. (C) A redukált nanoszál hálózat ellenállásának változása a hőmérséklet függvényében $\mathrm{N}_{2}$-atmoszférában.

A következő lépésben megkíséreltük a nanoszálak fém rézzé való visszaredukálását. A hőkezelést 1000 ppm-es hidrogénatmoszférában végeztük, az eredmény az 5.31. A ábrán látható. A réz-oxid redukciója rézzé kb. $570 \mathrm{~K}$-en $\left(297^{\circ} \mathrm{C}\right)$ indul meg. A nanoszál hálózat ellenállása (5.31. B ábra) jelentős mértékben csökkent, és az I-V karakterisztika is lineáris jellegüre változott, viszont a gate feszültség változtatásával semmilyen hatás nem volt mérhető. A hőmérséklet függvényében lineárisan változó ellenállás és a pozitív hőmérsékleti koefficiens (5.31. C ábra) a fémekre jellemző tulajdonság, amelyek igazolják a nanoszálak sikeres redukcióját.
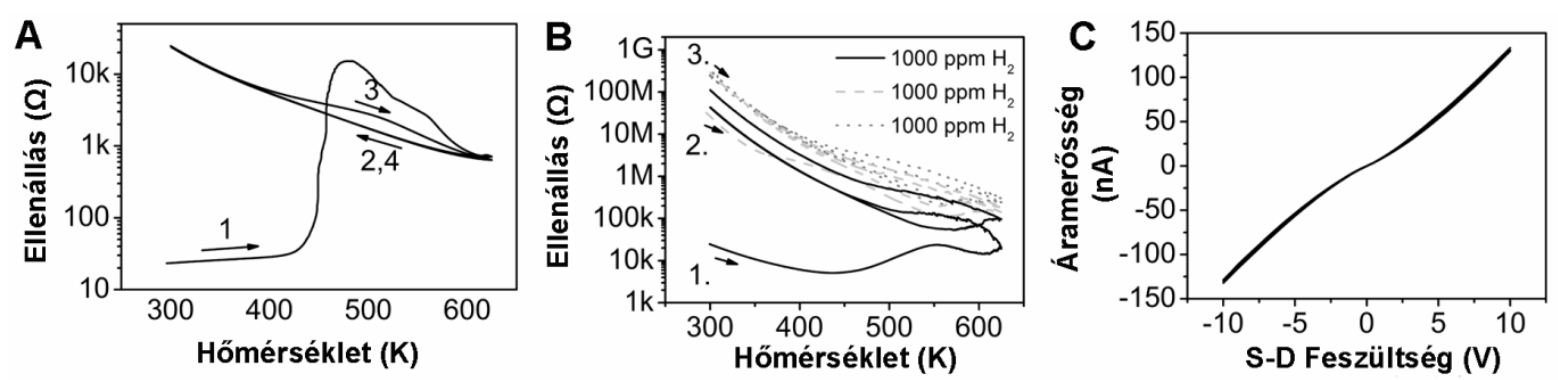

5.32. ábra: (A) Az ellenállás változása a hőmérséklet függvényében levegőn. Hőkezelés: $300 \mathrm{~K} \rightarrow$ $625 \mathrm{~K} \rightarrow 350 \mathrm{~K} \rightarrow 625 \mathrm{~K} \rightarrow 300 \mathrm{~K}$. (B) A redukciós kísérlet, 1000 ppm $\mathrm{H}_{2}$, során felvett ellenálláshőmérséklet görbék. (C) Áram-feszültség görbe szintetikus levegő atmoszférában; amelyet a méréseket, a hőkezeléseket és a redukciós kísérletet követően vettünk fel.

A redukált réz nanoszálak ismételt szintetikus levegő atmoszférában történő oxidációja során $\left(5.32\right.$. A ábra) az ellenállás $450 \mathrm{~K}\left(177^{\circ} \mathrm{C}\right)$ körül emelkedni kezd. Érdemes megfigyelni, hogy az oxidáció magasabb hőmérsékleten következik be, mint a korábbi 
esetben (5.29. B ábra) és az ellenállás emelkedése is jóval kisebb mértékü az első oxidáció utáni állapothoz képest. A 5.32. B ábra az 1000 ppm hidrogénatmoszférában történő redukálására tett kísérleteket mutatja be. A mérések alapján az adott hőkezelés és a reduktív atmoszféra sem elegendő a minta fémrézzé történő visszaredukálásához. A folyamat irreverzibilitása valószínüleg a nanoszál klaszterek képződésének következménye, amelyet a FESEM felvételeken (5.28. ábra) követhetünk nyomon. A klaszterképződés gátolja a réz nanoszálak teljes egészében történő érintkezését a reduktív atmoszférával, amely által a teljes redukció sem mehet végbe. Lehetséges, hogy a felületen visszamaradt HDA beburkolja a nanoszálakat és megakadályozza a további redoxi ciklusok végbemenetelét. Az alacsony vezetőképesség és a nem lineáris I-V karakterisztika (5.32. C ábra) is azt igazolja, hogy a redukció nem ment végbe és a nanoszál hálózatot feltehetően különböző oxidok alkotják. 


\subsection{CuPt ÉS CuPd KÉTFÉMES NANOCSÖVEK ELŐÁLLÍTÁSA ÉS JELLEMZÉSE}

\subsubsection{Kétfémes CuPt, CuPd nanocsövek előállítása}

A kétfémes nanocsövek előállításának első lépésében a hidrotermális úton előállított réz nanoszálak etanolos szuszpenzióját nitrogénatmoszférában bepároltuk. A tömeg meghatározását követően meghatározott mennyiségü abszolút etanolban homogén szuszpenziót készítettünk a nanoszálakból. Egy tipikus fémcsere helyettesítési reakció során $3 \mathrm{ml}(1 \mathrm{mg} / \mathrm{ml})$ réz nanoszál szuszpenziót legalább félórás ultrahangos kezelésnek vetettünk alá, majd legalább háromszor centrifugáltuk és DMSO-val mostuk. Miután a nanoszálakat DMSO-ban diszpergáltuk egy 50 ml-es háromnyakú gömblombikban, 5 percen keresztül visszafolyattuk nitrogénatmoszférában. A szuszpenzióhoz meghatározott mennyiségü, $1 \mathrm{mM}$ koncentrációjú DMSO-ban oldott nemesfémsó $\left(\mathrm{K}_{2} \mathrm{PtCl}_{4}, \mathrm{~K}_{2} \mathrm{PdCl}_{4}\right)$ oldatot csepegtettünk. Ezt követően a vörösesbarna szuszpenzió színe megváltozott. Az erősen kevertetett szuszpenzió visszafolyatását még 10 percig folytattuk, majd hagytuk lehűlni. A terméket desztillált vízzel mostuk és centrifugáltuk.

\subsubsection{Az eredmények értékelése}

A réz nanoszálak szuszpenziójához, $10^{-3} \mathrm{M}$-os $\mathrm{K}_{2} \mathrm{PdCl}_{4}$, vagy $\mathrm{K}_{2} \mathrm{PtCl}_{4}$-oldatokat a Cu nanoszálak mennyiségére vonatkoztatva a következö mólarányokban adagoltunk: 0,10 , 0,25, 0,50, 0,75, 1,00 és 1,50. A kísérleteket követően a mintákat mostuk, centrifugáltuk és jellemeztük.

\subsubsection{Mechanizmus}

A galvanikus fémcsere helyettesítési reakció során a réz nanoszálak vörösesbarna színe sötétszürkére változott, amely a $\mathrm{CuPt}$ és $\mathrm{CuPd}$ nanocsövek keletkezésére enged következtetni. A réz nanoszerkezetek, mint templátanyag használata két előnnyel is rendelkezik az ezüst nanoszerkezetekkel szemben: (i) kevésbé költséges és (ii) a termék tisztítása egyszerübb, mivel a folyamat során $\mathrm{CuCl}_{2}$ képződik, amely jól oldódik vízben és poláris oldószerekben szemben az AgCl-dal. A reakció közegeként DMSO-t választottuk, mert a vizes közegben a réz nanoszálak agglomerációja megnehezítette a folyamatot. Számos oldószerrel próbálkoztunk, mint pl.: abszolút etanol, 2-propanol, aceton stb. Végül a DMSO-t 
találtuk a legalkalmasabbnak, hiszen kevésbé toxikus, mint más poláris aprotikus oldószerek, mint pl.: a dimetilformamid (DMF).
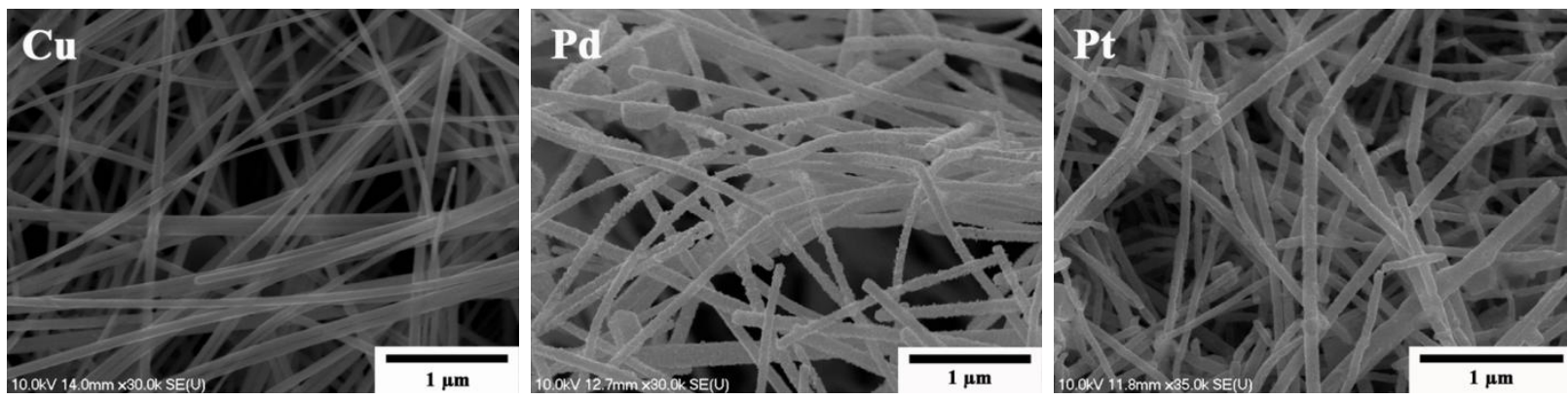

5.33. ábra: SEM felvételek: réz nanoszálak, 1,0 mólaránynál $\left(\mathrm{K}_{2} \mathrm{PdCl}_{4}\right.$ vagy $\left.\mathrm{K}_{2} \mathrm{PtCl}_{4} / \mathrm{Cu}\right)$ képződött $\mathrm{CuPd}$ és CuPt nanocsövek.

A reakció önként végbemegy, tekintve, hogy a $\mathrm{PtCl}_{4}{ }^{2-} / \mathrm{Pt}$ pár $(0,74 \mathrm{~V}$ SHE-hoz képest) és a $\mathrm{PdCl}_{4}{ }^{2-} / \mathrm{Pd}$ pár $(0,59 \mathrm{~V}$ SHE-hoz képest $)$ standard elektródpotenciálja nagyobb, mint a $\mathrm{Cu}^{2+} / \mathrm{Cu}$ páré $(0,34 \mathrm{~V}$ SHE-hoz képest), ezért a réz képes redukálni a Pt- és Pd-ionokat. Mivel a $\mathrm{Cu}^{+}+\mathrm{e}^{-}=0,52 \mathrm{~V}$ standard elektródpotenciállal rendelkezik a $\mathrm{Cu}^{2+}$-ionok képződése kedvezőbb, minta $\mathrm{Cu}^{+}$-ionoké. A lejátszódó elektrokémiai folyamatokat a következő egyenletek írják le:

$$
\begin{array}{lll}
\mathrm{Cu}(\mathrm{s})+\mathrm{PtCl}_{4}{ }^{2-}(\mathrm{aq}) & \longrightarrow & \mathrm{Pt}(\mathrm{s})+\mathrm{Cu}^{2+}(\mathrm{aq})+4 \mathrm{Cl}^{-}(\mathrm{aq}) \mathrm{E}=0,395 \mathrm{~V} \\
\mathrm{Cu}(\mathrm{s})+\mathrm{PdCl}_{4}{ }^{2-}(\mathrm{aq}) & \longrightarrow & \mathrm{Pd}(\mathrm{s})+\mathrm{Cu}^{2+}(\mathrm{aq})+4 \mathrm{Cl}^{-}(\mathrm{aq}) \mathrm{E}=0,25 \mathrm{~V}
\end{array}
$$

5. egyenlet: A galvanikus fémcsere helyettesítéskor lejátszódó reakciók.

A kétfémes termékek SEM (5.33. ábra) és TEM (5.34. ábra) felvételei igazolják, hogy a termékek megtartották a réz nanoszálak alakját, azaz az egydimenziós struktúrát. Szemben a réz nanoszálakkal, ezeknek a nanocsöveknek a felülete rücskös, amit a felületükön kivált nemesfém részecskék eredményeznek. A templátként használt réz nanoszálak átmérői $64 \pm 8$ nm, míg hosszuk néhány mikrométer volt.

A TEM felvételeken a CuPd és CuPt nanoszerkezetek meglehetősen áttetszőek, ami arra enged következtetni, hogy nanocsövek képződtek. A nanocső képződését már más 
kutatócsoportok is igazolták ezüst templátok segítségével nemesfém nanoszerkezetek előállításakor ${ }^{160,221}$.
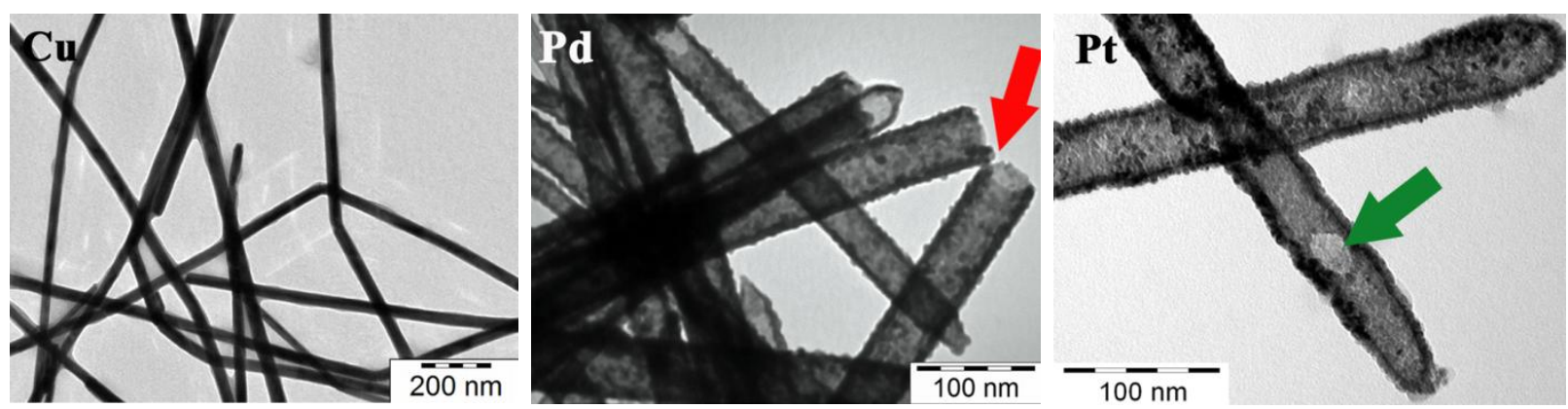

5.34. ábra: TEM felvételek: réz nanoszálak, 0,25 mólaránynál $\left(\mathrm{K}_{2} \mathrm{PdCl}_{4}\right.$ vagy $\left.\mathrm{K}_{2} \mathrm{PtCl}_{4} / \mathrm{Cu}\right)$ képződött CuPd és CuPt nanocsövek.

Annak ellenére, hogy a SEM felvételek szerint a nanocsövek végei zártak, néhány TEM felvételen (5.34. ábra piros nyíllal jelölt rész) látható a töréseknél, hogy a szerkezet üreges. Az is megfigyelhető, hogy a cserélt nanocsövek felületén viszonylag nagyméretü lyukak (5.34. ábra zöld nyíllal jelölt rész) láthatók, ami a reakció nagyon gyors lefutására utal $^{177}$. Nem elhanyagolható az a megfigyelés sem, hogy hosszabb tárolás során a nanocsövek „öregedése” volt megfigyelhető.

\subsubsection{Fémtartalom meghatározása EDS-sel}

A tisztítást követően energiadiszperzív röntgen spektroszkópiát alkalmaztunk a nanocsövek összetételének meghatározására. Az EDS spektrumokon rézre, platinára és palládiumra utaló erős intenzitású csúcsok jelentek meg (5.35. ábra). Az EDS vizsgálatok alapján fény derült arra, hogy a Cu-Pt és a Cu-Pd rendszerek különböző módon viselkednek.

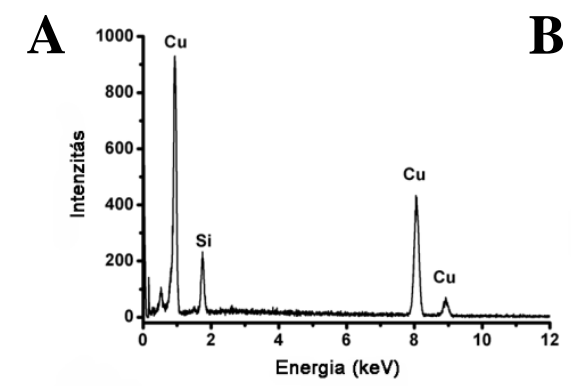

B

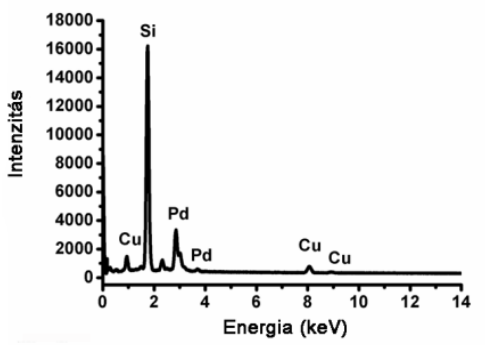

C

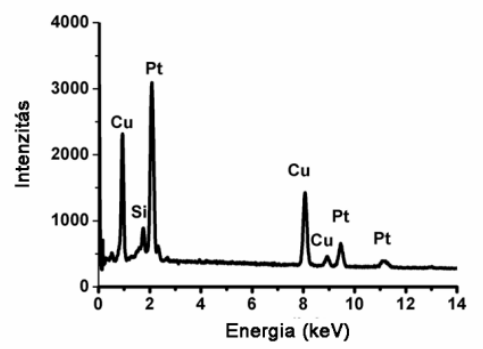

5.35. ábra: (A) Cu nanoszálakról, (B) CuPd és (C) CuPt nanocsövekről készült EDS spektrumok, 1,0 mólaránynál $\left(\mathrm{K}_{2} \mathrm{PdCl}_{4}\right.$ vagy $\left.\mathrm{K}_{2} \mathrm{PtCl}_{4} / \mathrm{Cu}\right)$. 
Az 5.36. ábra egy olyan diagramot mutat be, ahol a nemesfém- és a réztartalom atomszázalékban mért változása, az adagolt nemesfém $\left(\mathrm{K}_{2} \mathrm{PtCl}_{4}, \mathrm{~K}_{2} \mathrm{PdCl}_{4}\right)$ és a templátként használt réz mólarányának függvényében tüntettük fel. Az ábrán jól látható, hogy a CuPd görbe jóval meredekebben emelkedik. Az EDS alapján 1-1,5 mólaránynál a nanocsöveket majdnem 100 \%-ban Pd alkotja, ezzel szemben ennél a mólaránynál a CuPt nanocsövek 70 \% alatti mennyiségben tartalmaznak platinát.

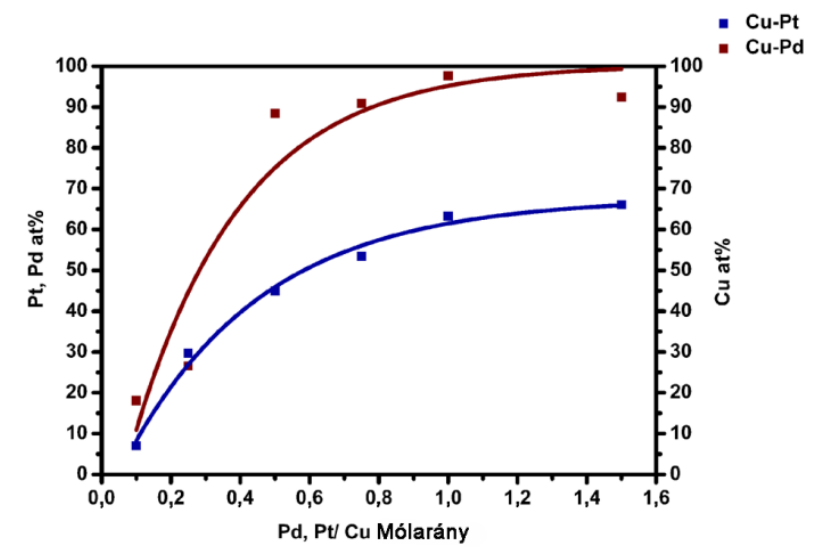

5.36. ábra: A CuPd és CuPt nanocsövek atomszázalékos összetétele a mólarány $\left(\mathrm{K}_{2} \mathrm{PdCl}_{4}, \mathrm{~K}_{2} \mathrm{PtCl}_{4} / \mathrm{Cu}\right)$ függvényében.

\subsubsection{A nanocsövek átméröinek méreteloszlása}

$\mathrm{Az}$ 5.38. ábra a méreteloszlási hisztogramok (5.37. ábra) alapján a nanocsövek átmérőinek változását mutatja be a $\mathrm{Pt}, \mathrm{Pd} / \mathrm{Cu}$ mólarányok függvényében. A templátként alkalmazott réz nanoszálak átmérőinek átlaga $64 \pm 8 \mathrm{~nm}$. Jól látható, hogy a két nemesfém esetében jelentősen eltérő az átmérők növekedése.
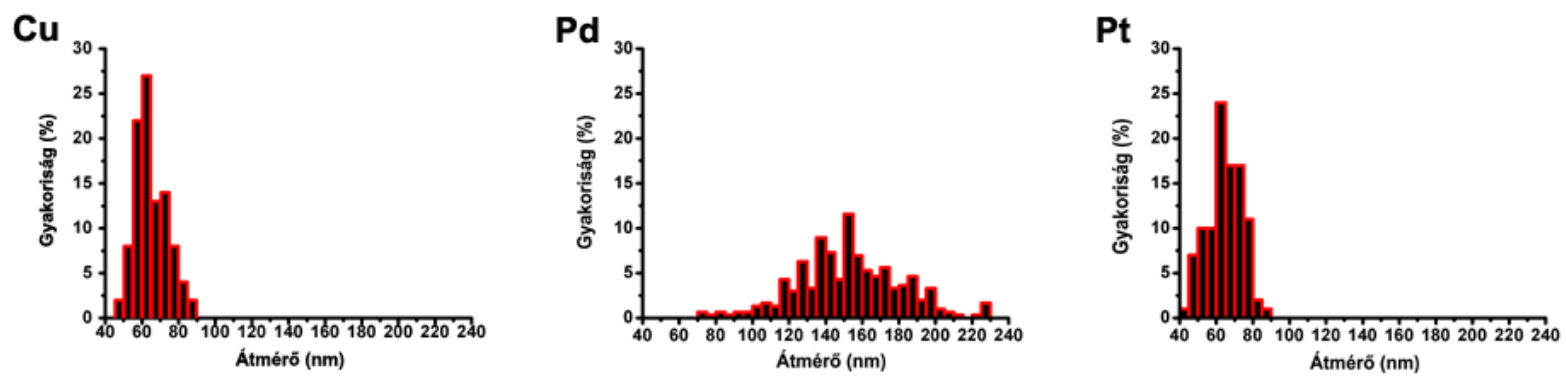

5.37. ábra: Átmérő eloszlási hisztogramok Cu NWs és 1,0 mólaránynál $\left(\mathrm{K}_{2} \mathrm{PdCl}_{4}, \mathrm{~K}_{2} \mathrm{PtCl}_{4} / \mathrm{Cu}\right)$ a $\mathrm{CuPd}$ és CuPt nanocsövek esetében. 
A platina fémcsere esetében méretnövekedés csak akkor volt megfigyelhetö, amikor a jelenlévő réz mennyiségéhez képest több $\mathrm{PtCl}_{4}{ }^{2-}$-ot adtunk a rendszerhez. Feltételezhetően a feleslegben adott $\mathrm{PtCl}_{4}{ }^{2-}$ további lerakódáshoz vezet a nanocsövek felületén, ami azok megvastagodását eredményezi. Mivel 1:1 arány esetén a nanocsövek megvastagodása nem figyelhető meg, a Pt feltehetően beépül a réz kristályszerkezetébe és CuPt ötvözetet alkot. Ezt a feltételezést az is alátámasztja, hogy a nanocsövek átméröinek eloszlása és szórása ( $\mathrm{Pt}: \mathrm{Cu}=1: 1$ mólaránynál) szinte megegyezik a templátként alkalmazott $\mathrm{Cu}$ nanocsövekével. Pt/Cu 1:1 mólaránynál a nanocsövek átmérőinek átlaga 64,4nm, a szórás 9,4nm.

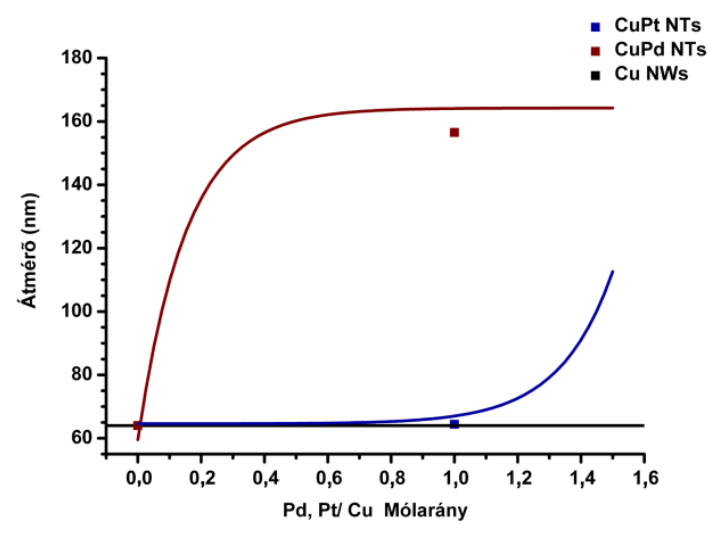

5.38. ábra: A nanocsövek átlagos átmérői a mólarány függvényében.

Ezzel szemben a CuPd nanocsöveknél már kismennyiségű $\mathrm{PdCl}_{4}{ }^{2-}$ is jelentős mértékü megvastagodást okozott. $\mathrm{Pd}: \mathrm{Cu}=1: 1$ mólaránynál a nanocsövek átmérője $(152,7 \pm 28,5 \mathrm{~nm})$ több mint 2,5-szeresére növekedett a kiindulási rézszálakhoz viszonyítva. Ebben az esetben feltételezésünk szerint a $\mathrm{PdCl}_{4}{ }^{2-}$ redukálódását követően a palládium nem épül be a kristályszerkezetbe, hanem a nanoszálak felületére rakódik le. A nanocsövek átméröinek eloszlása lognormális és a szórás jóval nagyobb, mint a $\mathrm{Cu}$ nanoszálak és a $\mathrm{CuPt}$ nanocsövek esetében, ami diffúzióvezérelt lerakódási folyamatra utal.

\subsubsection{Röntgendiffrakciós vizsgálat eredményei}

A növekvő palládiumkoncentráció mellett elöállított nanocsövek röntgen diffraktogramjait az 5.39. ábra foglalja össze. A templátként használt réz nanoszálak diffraktogramján három jól elkülöníthető reflexiót azonosítottunk $2 \theta=43,3,50,4$ és $74,2^{\circ}$-nál, amelyek egyértelmüen az fcc réz (111), (200) és (220) kristálylapjaihoz rendelhetők. Néhány diffraktogramon megjelennek a $\mathrm{Cu}_{2} \mathrm{O}$ (JCPDS ICDD kártya 78-2076) valamely (110), (111), 
(200), (220) és (311) kristálylapjaihoz tartozó reflexiói $2 \theta=29,5,36,4,42,3,61,5$ és $73,6^{\circ}$-nál. $\mathrm{A} \mathrm{Cu}_{2} \mathrm{O}$ reflexiók megjelenése a levegőn való tárolás, illetve a minta előkészítés során végbemenő oxidációs folyamat eredménye. Már viszonylag alacsony mólaránynál $(0,1)$ megjelennek (5.39. A ábra) az fcc kristályszerkezettel rendelkező Pd (JCPDS ICDD kártya 46-1043) (111), (200), (220) és (311) kristálylapjaira jellemző reflexiók $2 \theta=39,8$, 46,6, 67,2 és 81,9 foknál. $\mathrm{A} \mathrm{K}_{2} \mathrm{PdCl}_{4}$ mennyiségének növelésére a $\mathrm{Cu}$-re és a $\mathrm{Cu}_{2} \mathrm{O}$-ra jellemző karakterisztikus reflexiók eltüntek, habár a 1:1 mólaránynál (5.39. C ábra), 20=29,5 foknál egy kis intenzitású csúcs még a $\mathrm{Cu}_{2} \mathrm{O}$ jelenlétére utal a mintában. A mintában lévő réztartalmat az EDS mérések is alátámasztották, ezek alapján a nanocsövek 2,3 \%-ban tartalmaznak rezet.
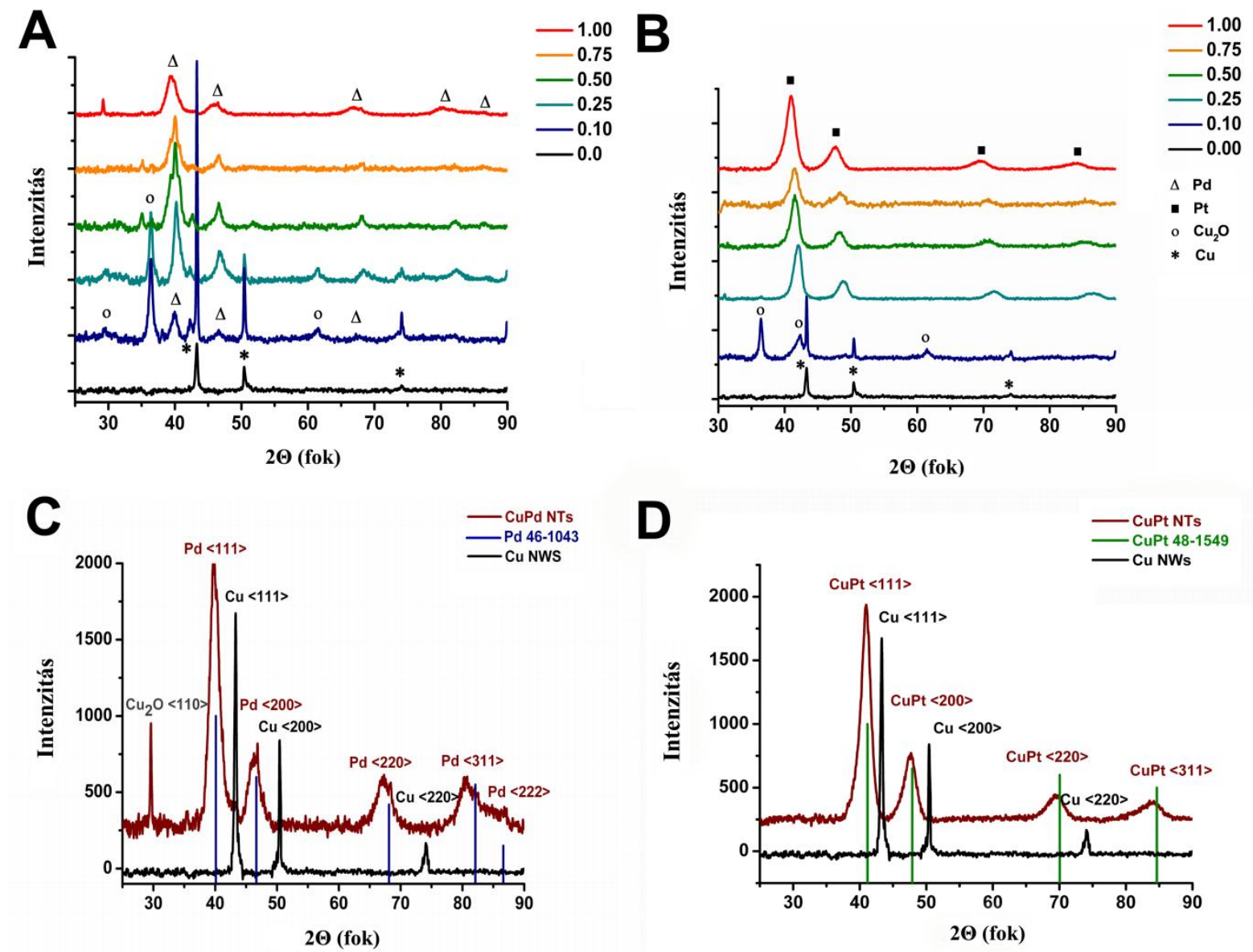

\subsection{9. ábra: Röntgen diffraktogramok: Különböző mólarányoknál cserélt nanoszálak $(\mathrm{A}) \mathrm{Pt}$ csere $(\mathrm{B}) \mathrm{Pd}$ csere. (C) Pt csere és (D) Pd csere 1,0 mólaránynál $\left(\mathrm{K}_{2} \mathrm{PdCl}_{4}\right.$ vagy $\left.\mathrm{K}_{2} \mathrm{PtCl}_{4} / \mathrm{Cu}\right)$.}

A Cu-Pd rendszerhez hasonlóan a $\mathrm{Cu}-\mathrm{Pt}$ rendszerben (5.39. B ábra) is megjelennek

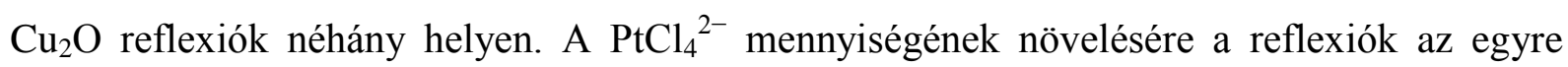
kisebb $2 \theta$ szögek felé tolódnak el, ugyanakkor a $\mathrm{Cu}_{2} \mathrm{O}$-ra jellemző reflexiók eltünnek. $\mathrm{Az}$ 
(5.39. D ábra) 1,0 mólaránynál előállított nanocsövek diffraktogramján jól láthatóak a CuPt ötvözet (JCPDS ICDD kártya 48-1549) (111), (200), (220) és (311) kristálylapjaira jellemző reflexiók $2 \theta=41,0,47,7$, 69,7 és 84,7 foknál. Az EDS mérések ezzel analóg eredményeket mutattak, melyek alapján a nanocsöveket megközelítőleg 36,8 \%-ban alkotja réz.

$\mathrm{Az}$ 5.40. ábra a röntgen diffraktogramokból meghatározott d értékeket az 1/M függvényében mutatja be. Ez alapján a $\mathrm{Pd} / \mathrm{Cu}=1,0$ mólarány mellett előállított nanocsövek rácsállandója 3,779 Å. Ez valamivel kisebb, mint a JCPDS ICDD 46-1043 kártya szerinti 3,890 Å. A templátként alkalmazott réz nanoszálak rácsállandója 3,619 A. A rácsállandó eltérését rendezetlen kristályszerkezet eredményezheti. A $\mathrm{CuPt}$ nanocsövek esetében meghatározott rácsállandó $3,753 \AA$, mely érték nagy hasonlóságot mutat az irodalomban közölt CuPt ötvözetek rácsállandójával (3,796 ̊̊).

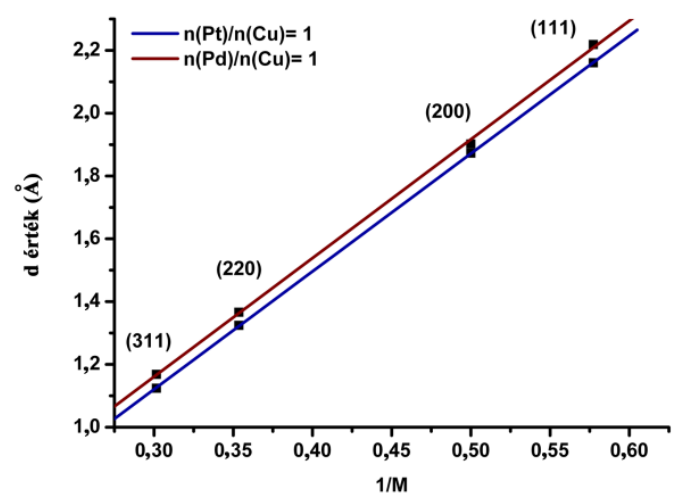

5.40. ábra: A CuPd és CuPt nanocsövek d értékei az 1/M függvényében, 1,0 mólaránynál $\left(\mathrm{K}_{2} \mathrm{PdCl}_{4}, \mathrm{~K}_{2} \mathrm{PtCl}_{4} / \mathrm{Cu}\right)$.

\subsubsection{Kialakulási hipotézis}

A nanoszerkezetek felületén megjelenő kis rések (5.41. ábra) arra engednek következtetni, hogy a korróziós folyamat nem a teljes felületen megy végbe, hanem lokálisan iniciált. A közegben megjelenő, a $\mathrm{K}_{2} \mathrm{PdCl}_{4}$-ból, vagy $\mathrm{K}_{2} \mathrm{PtCl}_{4}$-ból származó kloridionok a tömbfázisbeli korróziós folyamatokhoz hasonlóan a nanoszerkezetek korróziójában is jelentős szerepet töltenek be. A felületen adszorbeálódó kloridionok fokozzák a felületi diffúzió sebességet, így felgyorsítják a korróziós folyamatot ${ }^{222}$.

A SEM BSE (visszaszórt elektron) felvételek arról árulkodnak, hogy a nanoszálak felületén rések keletkeztek, amelyeken keresztül a nanoszálak anyaga belülről oxidáció révén távozni tudott (5.41. ábra). 
A palládiumcserélt nanocsövek $\mathrm{K}_{2} \mathrm{PdCl}_{4}: \mathrm{Cu}$ 1:1 mólaránynál az EDS mérések alapján 2,3\%-ban tartalmaznak rezet. A rézatomok a résen keresztül kilépnek és a felszín közelében redukálják a $\mathrm{PdCl}_{4}{ }^{2-}$-ionokat az oldatban, amelyek a nanoszál felületére eleinte csak kis szigetek formájában, majd a szálat teljesen bevonva rakódnak le, megvédve ezzel a réz nanoszál felületét a korróziós folyamattól.
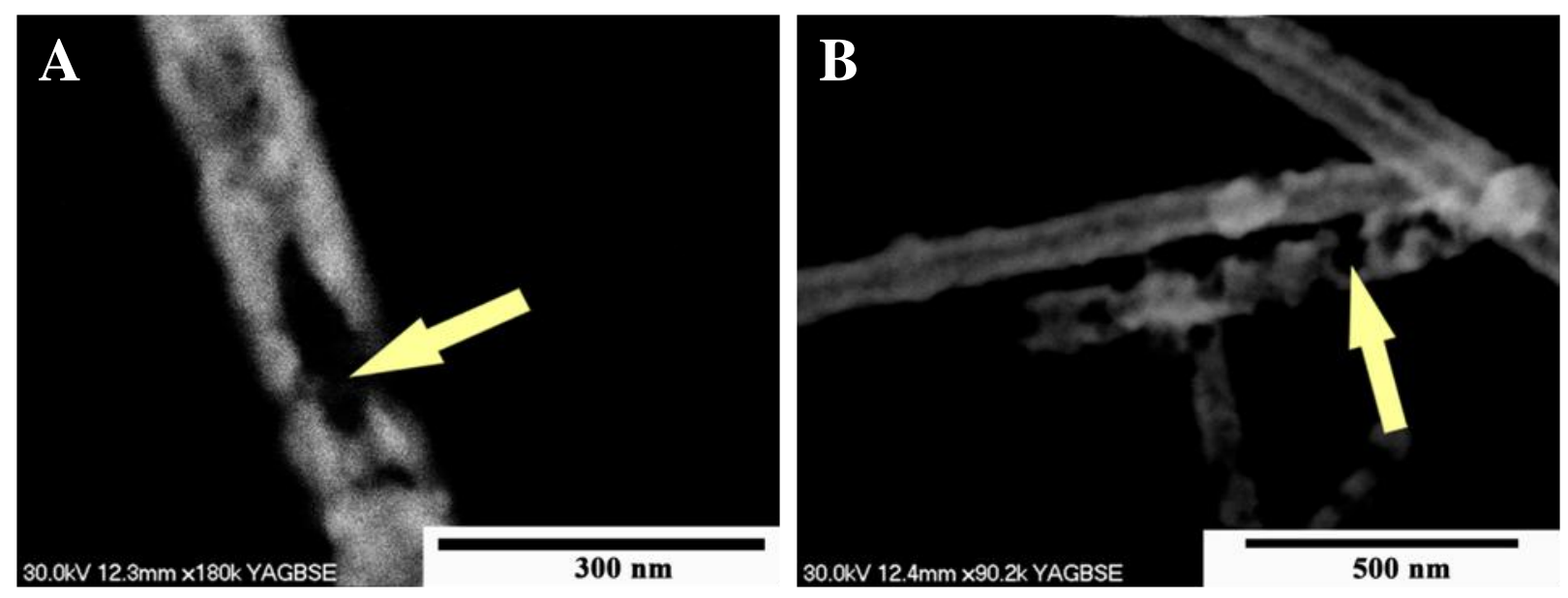

5.41. ábra: $1,5\left(\mathrm{~K}_{2} \mathrm{PdCl}_{4}\right.$ vagy $\left.\mathrm{K}_{2} \mathrm{PtCl}_{4} / \mathrm{Cu}\right)$ mólaránynál előállított $(\mathrm{A}) \mathrm{CuPd}$ és $(\mathrm{B}) \mathrm{CuPt}$ nanoszálak $\mathrm{SEM}$ BSE felvételei.

Az oxidációs folyamat elörehaladtával egyre több és több palládium rakódik le a nanoszál felületén, mely folyamat rücskös felszínü nanocsövet eredményez. Mivel az EDS analízis fényt derített arra, hogy a nanoszerkezetek alig tartalmaznak rezet, feltételezhető, hogy a kialakult szerkezet üreges (5.34. ábra). Ugyanakkor a nanocsöveknek a végei zártak, mint az a SEM felvételeken is látható (5.33. ábra). A mólarány emelése a nanocsövek átméröinek megnövekedését eredményezte, mellyel párhuzamosan - az EDS analízis alapján - csökkent a réztartalom. Valószínűleg ezen a hömérsékleten és ebben a közegben nem képzödik CuPd ötvözet, mivel az XRD mérések nem mutattak ötvözetre utaló reflexiókat. A folyamatos palládium lerakódás a nanoszálak felszínén azok megvastagodását idézi elö.

Az XRD analízis azt sugallta, hogy palládium-réz cserével szemben a platina ötvözetet képez a rézzel. Kimutattuk, hogy $\mathrm{K}_{2} \mathrm{PtCl}_{4}$ adagolásra a platinatartalom $66 \%$-ra emelkedett, majd ez az érték a Pt:Cu mólarány további emelésével nem változott. A galvanikus fémcsere helyettesítési reakcióban ez a megtorpanás a két fém elektrokémiai potenciálkülönbsége miatt bekövetkező gyors ötvözetképződéssel magyarázható. A folyamat korai fázisában a $\mathrm{PtCl}_{4}{ }^{2-}$ gyorsan reagál a rézatomokkal, azonban a folyamat során kevésbé reaktív CuPt felszín alakul ki. 2010 végén $\mathrm{Lu}$ és munkatársai hasonló módszerrel állított elő $\mathrm{Au}, \mathrm{CuPt}$ és $\mathrm{CuPd}$ 
nanocsöveket réz nanoszálakból. A galvanikus fémcsere helyettesítési reakciót szobahőmérsékleten 40-60 percen keresztül végezték. Az általuk elöállított $\mathrm{Pd}$ és $\mathrm{Pt}$ nanocsövek kb. 10-12\%-ban tartalmaztak rezet az EDS mérések alapján. A kiindulási nanoszálak 50-150 nm-esek voltak, a nanocsövek valamivel vastagabbak $(80-150 \mathrm{~nm})$. A nanocsövek az ő esetükben is zártak voltak ${ }^{177}$.

$\mathrm{Az}$ 5.42. ábra egy sematikus rajzon keresztül mutatja be a kétfémes CuPt és $\mathrm{CuPd}$ nanocsövek kialakulását.

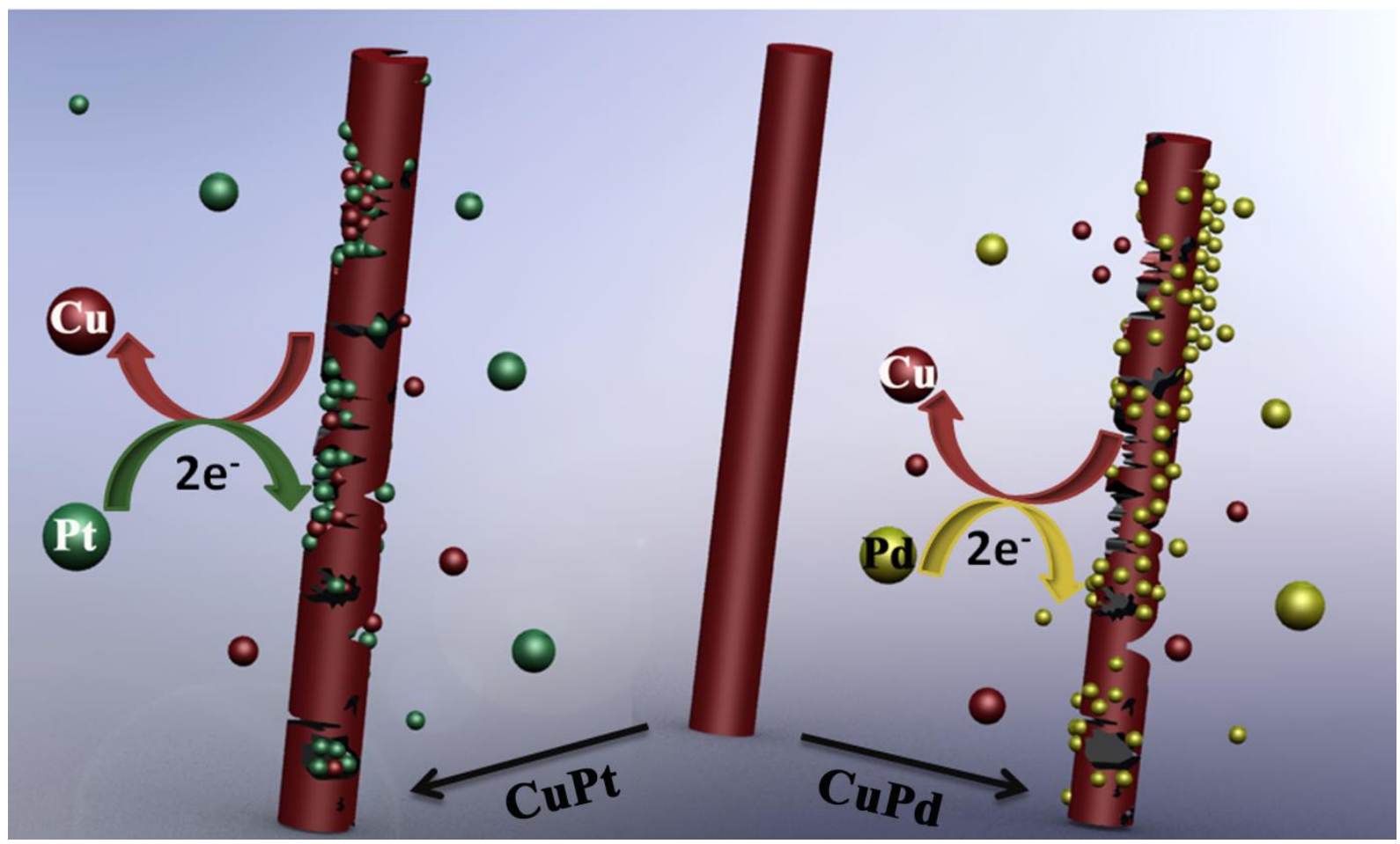

5.42. ábra: CuPt és CuPd nanocsövek feltételezett kialakulási mechanizmusának sematikus rajza. A zöld, sárga és bordó gömbök a $\mathrm{Pd} / \mathrm{PdCl}_{4}{ }^{-}-, \mathrm{Pt} / \mathrm{PtCl}_{4}{ }^{-}$- és $\mathrm{Cu}^{2+}$-ionokat reprezentálják.

A különbségekben szerepe van a Kirkendall-féle anyagtranszport jelenségnek is ${ }^{223}$. Kirkendall kísérletei elsőként igazolták, hogy az atomos diffúzió lyukakon (vakanciákon) keresztül történik. McIlwarth és munkatársai $\mathrm{Cu} @ \mathrm{Pt}(\mathrm{Cu}$ mag és $\mathrm{Pt}$ köpeny) és $\mathrm{Pt} @ \mathrm{Cu}(\mathrm{Pt}$ mag és $\mathrm{Cu}$ köpeny) mag-héj nanoszerkezetek közti szerkezeti különbségeket fedeztek fel, és kimutatták, hogy a $\mathrm{Pt}$ diffúziója $\mathrm{Cu}$-be gyorsabb, mint a $\mathrm{Cu}$ diffúziója Pt-ba ${ }^{224}$. Bélanger és munkatársai részletesen vizsgálták a grafitelektródra felvitt rézrétegen képződő $\mathrm{Pd}$ lerakódások morfológiáját ${ }^{225}$. Kimutatták, hogy a kialakuló morfológia erősen függ a $\mathrm{PdCl}_{2}$ mennyiségétől. Alacsony, $5 \mathrm{mM} \mathrm{PdCl}_{2}$ koncentráció esetén a $\mathrm{Pd}$ csak néhol borította be a rézfelszínt, így a szabadon lévő rézatomok és a Pd-vel borítottak is oxidálódtak és kioldódtak. 
Nagyobb $\mathrm{PdCl}_{2}$ koncentrációt alkalmazva palládium héj jön létre, ami beborítja a réz magot, ami ezután nem tud oxidálódni.

Annak dacára, hogy a $\mathrm{Cu}-\mathrm{Pd}$ rendszer egy jól ismert ötvözet a diffúziós sebességekben keresendő annak oka, hogy miért nem alakul ki a két fém ötvözete az adott hőmérsékleten. A morfológiai különbségekért feltehetően a reakció folyamán bekövetkező elektrokémiai potenciálkülönbségekben bekövetkező változások tehetők felelőssé. Feltehetően a kialakuló $\mathrm{CuPt}$ ötvözetben levő réz jóval magasabb elektrokémiai potenciállal rendelkezik, amely révén, annak oxidációja nem megy végbe. Jól ismert tény, hogy eltérő szilárdfázisú diffúziósebességek pórusos és/vagy üreges nanoszerkezeteket eredményeznek oxidációs és ötvöződési folyamatokban ${ }^{223}$, ami magyarázatul szolgálhat a nanocsövek kialakulására.

A kétfémes nanocsövek felhasználása leginkább a katalízis területén várható. A protoncsere membrán üzemanyagcellákban alkalmazott katalizátorok élettartamának meghosszabbítása jelentős kihívás a kutatók számára, amitől a celláknak a kereskedelmi forgalomba történő kerülése függhet ${ }^{221}$. A hordozós Pt-katalizátorok, mint például a $\mathrm{Pt} / \mathrm{C}$ katalizátor, az oxigén redukciós reakcióval (ORR) szemben mutatott kiemelkedő katalitikus aktivitásának köszönhetően az egyik leggyakrabban használt katódos katalizátorok. Ezek a katalizátorok azonban meglehetősen rövid élettartammal bírnak. Az elmúlt években egyéb, alacsony költségü, hosszabb élettartamú és magas ORR aktivitású nemplatina katalizátorok használata került előtérbe. Több kutatócsoport is kimutatta, hogy átmenetifémekkel kombinált palládium nanoszerkezetek megemelkedett katalitikus aktivitást mutatnak az ORR-ban ${ }^{226-229}$. Ding és kollégái nanocsöves, mezopórusos szerkezettel rendelkező kétfémes $\mathrm{PdCu}$ nanokompozitokat állított elő galvanikus fémcsere helyettesítési reakcióval ${ }^{227}$. Ezeken a kereskedelmi forgalomban kapható Pt/C-katalizátorhoz képest jelentős mértékben jobb ORR katalitikus aktivitást mértek. Ding csoportja azt is kimutatta, hogy az általuk előállított $\mathrm{PtCu}$ kétfémes nanoszerkezetek a metanol elektrooxidációjában magas aktivitással és kiemelkedő CO-dal szembeni ellenállóképességgel rendelkeznek ${ }^{230}$. Többen is igazolták, hogy a CuPd rendszer is sikeresen alkalmazható nitrátok elektrokatalitikus redukciójában ${ }^{231,232}$.

Ezek a kutatási eredmények hüen tükrözik a CuPd és CuPt kétfémes nanoszerkezetek alkalmazhatóságát a katalízis több területén is. A galvanikus fémcsere helyettesítéssel előállított kétfémes nanocsövek feltehetően kiválóan alkalmazhatóak más olyan területeken is, ahol nagy felület:térfogat arány szükséges. 


\section{6. ÖSSZEFOGLALÁS}

Az egydimenziós (1D) nanoszerkezetek (nanoszálak, nanorudak, nanocsövek stb.) lenyügöző és egyedi tulajdonságaiknak köszönhetően egyre növekvő érdeklődést vívnak ki maguknak a nanotechnológia területén. Szemben a 0D-s nanoszerkezetekkel (kvantum dotok, nanorészecskék), az 1D nanoszerkezetek alkalmasabb modellnek bizonyultak az elektromos, mechanikai és optikai tulajdonságok kvantumhatárolástól és a mérettől való függésének tanulmányozására. Annak ellenére, hogy a nanoszálak alkalmasak lehetnek nanotechnológián alapuló eszközökben történő felhasználásra, eddig ez a terület igencsak döcögősen haladt. A problémát az egységes méretekkel, kristályszerkezettel, kémiai összetétellel rendelkező nanoszálak hiányának tudhatjuk be. Ezt felismerve egyre több kutatás, így a jelen munka is, a „jó minőségü” 1D nanoszerkezetek előállítására, jellemzésére és felhasználására koncentrálódik.

Dolgozatomban a réz nanoszálak hidrotermális úton történő előállítását, kialakulási mechanizmusát vizsgáltam, és követtem a reaktánsoknak és különböző adalékanyagoknak a réz nanoszerkezetek morfológiájára gyakorolt hatását. Vizsgáltam továbbá a nanoszálak elektromos tulajdonságait. Dolgozatom második felében galvanikus fémcsere helyettesítési reakcióval egydimenziós, nagy fajlagos felületű nemesfém nanoszerkezetek előállítását mutattam be.

A doktori disszertációban bemutatott eredményeket röviden az alábbiakban ismertetem:

A már ismert galvanikus fémcsere helyettesítési reakciót továbbfejlesztve pórusos $\mathrm{Au}$, Pt és $\mathrm{Pd}$ nanorudakat állítottunk elő. $\mathrm{Az}$ új módszer lényeges lépését elektrokémiai leválasztással elöállított nikkel nanorudak és nemesfémsók ( $\left.\mathrm{HAuCl}_{4}, \mathrm{~K}_{2} \mathrm{PtCl}_{6}, \mathrm{~K}_{2} \mathrm{PdCl}_{4}\right)$ reakciója képezi. A nanorudak pásztázó elektronmikroszkópos vizsgálatával meghatároztuk a nanorudak átlagos átmérőit, magyarázatot adtunk a méretnövekedésre és az eltérő méretekre.

A nanorudak röntgendiffrakciós, röntgen-fotoelektron spektroszkópiás és $\mathrm{N}_{2}$ adszorpciós vizsgálatával bizonyítottuk, hogy a galvanikus fémcsere helyettesítési reakciót követően nikkel-szennyezés nem maradt vissza a templátként alkalmazott nikkel nanorudakból. Az adszorpciós vizsgálatok alapján a nanorudak fajlagos felülete megközelítőleg $30 \mathrm{~m}^{2} / \mathrm{g}$-nak adódott. 
A platina és palládium nanorudak katalitikus aktivitását hidrogénezési reakcióban vizsgáltuk, melyhez az etilén hidrogénezését, mint modellreakciót választottuk. A méréseket 10-40 ${ }^{\circ} \mathrm{C}$ (263-313 K) hőmérséklettartományban végeztük el. Az Arrhenius görbékből meghatározott látszólagos aktiválási energiák: 43,7 $\pm 1,7 \mathrm{~kJ} / \mathrm{mol}$ a Pt és 29,4 $\pm 1,3 \mathrm{~kJ} / \mathrm{mol}$ a Pd nanorudak esetében.

Kidolgoztunk egy új hidrotermális eljárást réz nanoszálak előállítására, mellyel mikrométeres hosszúságú és legalább 50 hossz/átmérő aránnyal rendelkező nanoszálakat kaptunk. A nanoszálakat elektronmikroszkópiával és XRD-val jellemeztük. A mikroszkópos felvételek alapján a nanoszálak átlagos átmérője $64 \pm 8$ nm-nek adódott. Elektrondiffrakciós mérésekkel igazoltuk, hogy a szálak egykristályosak.

Vizsgáltuk a szintézisben használt 1-hexadecil-amin (HDA) és glükóz adalékanyagok szerepét. Kísérletsorozatokkal meghatároztuk a reakcióhoz szükséges optimális glükóz/HDA/ $\mathrm{CuCl}_{2}$ arányt, mely összetételnél a termék az egységes nanoszálak mellett csak igen kis mennyiségben tartalmaz egyéb morfológiájú nanorészecskéket.

Kimutattuk, hogy különböző rézsók (réz-nitrát, réz-klorid és réz-acetát) használata esetén csak a réz-klorid jelenlétében képződnek nanoszálak, azaz a kloridionok jelentős szerepet töltenek be a nanoszálak kialakulásában. Réz-acetátból és réz-nitrátból kiindulva tanulmányoztuk a nátrium-klorid, illetve nátrium-bromid adagolás hatását a képződő réz nanoszerkezetek morfológiájára.

A réz nanoszálak növekedési mechanizmusának megismerése érdekében követtük a nanoszálak kialakulását az idő függvényében. A TEM felvételek alapján kimutattuk, hogy 1 órás szintézist követően a mintát 2,1 $\pm 0,7 \mathrm{~nm}$ nanorészecskék alkotják és a HDA lapok formájában jelenik meg. 2-3 óra elteltével már néhány nanoszál is megjelenik a mintákban, melyeket a HDA feltekeredve vesz körül. Megfigyeléseink alapján egy lehetséges mechanizmust javasoltunk a nanoszálak kialakulására.

A nanoszálak elektromos tulajdonságinak mérése során oxidatív és reduktív atmoszférában hőkezelést alkalmaztunk. A vizsgálatok klaszterképződést mutattak ki a szálak felületén. Az első redoxi ciklust követően a nanoszálakat nem tudtuk újra oxidálni és redukálni.

Egy új módszert dolgoztunk ki CuPt és CuPd kétfémes nanocsövek előállítására réz nanoszálakon végzett galvanikus fémhelyettesítési reakcióval. A kétfémes nanoszálakon elvégzett elektronmikroszkópos és energiadiszperzív spektroszkópiai mérések alapján 
megállapítottuk, hogy a folyamat során a nanoszálak felületén kis rések, üregek keletkeznek. Az elektronmikroszkópos felvételek fényt derítettek arra is, hogy míg a Pt esetében nem történik jelentős változás a nanoszálak átmérőiben, addig a Pd fémcsere esetében a nanoszálak jelentős megvastagodása következik be már kis koncentrációban adagolt $\mathrm{PdCl}_{4}{ }^{2-}$ hatására.

Röntgendiffrakciós vizsgálatokkal kimutattuk, hogy a $\mathrm{Cu}-\mathrm{Pt}$ csere esetén a nanoszálakat $\mathrm{CuPt}$ ötvözetet alkotja és réztartalmuk $\sim 33$ atom $\%$, ami további $\mathrm{PtCl}_{4}{ }^{2-}$ adagolással nem csökkenthető. Ezzel szemben, $\mathrm{Cu}-\mathrm{Pd}$ fémcsere esetében, a $\mathrm{PdCl}_{4}{ }^{2-}$ koncentrációjának emelésével a nanoszálak réztartalma 2-3 atom \% körüli értékre csökkenthető és XRD-vel nem mutatható ki ötvözet képződése. 


\section{SUMMARY}

One-dimensional nanostructures (i.e., nanowires, nanorods, nanotubes) have gained steadily growing interest in the field of nanotechnology owing to their fascinating and unique properties. In comparison with the zero dimensional nanostructures, such as quantum dots and nanoparticles, 1D nanostructures have proved to be better models for the investigation of the dependence of electronic transport and optical and mechanical properties on dimensionality and quantum confinement. Consequently, nanowires, in particular, should play an important role in future nanodevices, contrary to the fact that this field of nanotechnology have advanced relatively slowly until very recently. This problem must have been caused by the lack of nanowires with well-controlled sizes, crystallinity and chemical composition hindering their utilization in devices. Recognizing this fact, more and more research projects have been focused on the synthesis, characterization and utilization of nanowires.

In this thesis the mechanism of formation, the electrical properties and the morphological characterization of copper nanowires synthesized by a simple hydrothermal procedure have been discussed. The role of each reactant and the effect of copper and other salts in the formation of nanowires have also been studied. Furthermore, 1D noble metal nanorods (Pt, Pd) with high specific surface area have been prepared by applying the galvanic exchange reaction.

The major results of this PhD thesis are the following:

The well-known galvanic exchange reaction has been improved for the synthesis of porous $\mathrm{Au}, \mathrm{Pt}$, and $\mathrm{Pt}$ nanorods produced by exposing Ni nanorods to aqueous solutions of the corresponding metal salts $\left(\mathrm{HAuCl}_{4}, \mathrm{~K}_{2} \mathrm{PtCl}_{6}, \mathrm{~K}_{2} \mathrm{PdCl}_{4}\right)$. Scanning electron microscopy (SEM) was used to study the morphology of the nanorods. Based on SEM images the diameter size distribution was assessed and a possible explanation for the size increase and altering sizes of the nanorods was suggested.

The results of powder X-ray diffraction (XRD), X-ray photoelectron spectroscopy, and $\mathrm{N}_{2}$ adsorption-desorption measurements clearly indicated that no nickel residues from the $\mathrm{Ni}$ templates are present in the porous nanorods. The specific surface area of the $\mathrm{Pt}, \mathrm{Pd}$ and $\mathrm{Au}$ nanostructures were found to be $\sim 30 \mathrm{~m}^{2} / \mathrm{g}$. 
In order to check their catalytic activities, the porous Pd and Pt nanorods have been studied in a model reaction, namely in the hydrogenation of ethylene. The measurements were carried out in the temperature range of $-10-40{ }^{\circ} \mathrm{C}(263-313 \mathrm{~K})$. Based on the Arrhenius plots the apparent activation energies for Pt and Pd nanowires were found to be: $43.7 \pm 1.7 \mathrm{~kJ} / \mathrm{mol}$ and $29.4 \pm 1.3 \mathrm{~kJ} / \mathrm{mol}$, respectively.

We have demonstrated a novel hydrothermal route for the preparation of copper nanowires with lengths ranging from several hundreds of nanometers to several micrometers and high aspect (above 50) ratio. Nanowires were characterized by electron microscopy and $\mathrm{XRD}$. The microscopy records showed that the $\mathrm{Cu}$ nanowires have a uniform diameter of $64 \pm 8 \mathrm{~nm}$. The electron diffraction (ED) analysis revealed and proved that the nanowires were single crystals.

In order to assess the optimal ratio of glucose/1-hexadecylamine (HDA)/ $\mathrm{CuCl}_{2}$ needed to obtain a final product composed of mostly nanowires, the role of HDA and glucose have been investigated by a series of experiments.

We have demonstrated that using copper-nitrate or copper-acetate instead of copperchloride no nanowires were formed, indicating that the chloride ions have an indispensable role in the formation mechanism. Furthermore, variation in the morphology of the copper nanostructure was investigated by adding sodium-chloride or sodium-bromide when copperacetate or copper-nitrate were used as $\mathrm{Cu}$ sources for the syntheses.

Since the growth mechanism of copper NWs is not fully understood yet, hydrothermal syntheses of various durations were performed in order to gain insight into the growth kinetics. In the case of 1 hour synthesis the samples were mostly composed of $2.1 \pm 0.7 \mathrm{~nm}$ copper nanoparticles and hardly any nanowires appeared. At this early stage the HDA was observable as planes in the TEM images. On increasing the synthesis period to 2 and 3 hours, some copper nanowires showed up and the structure of HDA appeared to be coiled rather than planar. Based on our investigations we have suggested a possible mechanism: the initial formation of nanoparticles is followed by the growth of NWs at later stages.

The electrical properties of copper NWs have been measured using oxidative/reductive atmospheres and heating cycles. Cluster formation was observed during electrical testing of $\mathrm{Cu}$ NWs. The sample could not be reduced and re-oxidized again after the first oxidationreduction cycle. 
We have developed a new method for the preparation of $\mathrm{CuPd}$ and $\mathrm{CuPt}$ bimetallic nanotubes (NTs) by applying the galvanic replacement reaction. The NTs were characterized by transmission electron microscopy (TEM), scanning electron microscopy (SEM) combined with energy dispersive X-ray spectroscopy (EDS) and X-ray diffraction (XRD) techniques. The BSE images revealed formation of etch pits on the surface of the NWs/NTs indicating the absence of copper, being removed by oxidation from the interior of the NWs. Electron microscopy studies shed light on the different behavior of the two systems. When exchanging copper with $\mathrm{Pt}$, size increase was experienced only after the addition of more $\mathrm{PtCl}_{4}{ }^{2-}$ salt than the amount of $\mathrm{Cu}$ present. Contrary to this phenomenon, it is clearly seen that the size increase of the CuPd nanowires has already been triggered by adding a small amount of $\mathrm{PdCl}_{4}{ }^{2-}$.

As for Pt, the XRD analysis suggests that Pt probably diffuses into the copper to form $\mathrm{CuPt}$ alloy. Upon adding more and more $\mathrm{K}_{2} \mathrm{PtCl}_{4}$ solution to the system the $\mathrm{Pt}$ content increases until about $66 \%$, that is, the copper content of the NWs ( $~ 33$ atomic \%) cannot be further decreased. On the contrary, the $\mathrm{Cu}-\mathrm{Pd}$ metal exchange reaction resulted in a much lower copper content ( 2-3 atomic \%) and no formation of CuPd alloy was shown by XRD analysis. 


\section{KÖSZÖNETNYILVÁNÍTÁS}

Elsősorban köszönettel tartozom témavezetőmnek, Dr. Kónya Zoltán tanszékvezető egyetemi docensnek munkám során nyújtott segítségéért és tanácsaiért. Köszönöm Dr. Kukovecz Ákos egyetemi docensnek, hogy segítséget nyújtott eredményeim értelmezésében és publikálásában. Segítségük és kitartó ösztönzésük nélkül ez a munka nem készülhetett volna el.

Ezúton szeretnék köszönetet mondani Dr. Kiricsi Imre egykori tanszékvezető egyetemi tanárnak, amiért lehetővé tette számomra, hogy az Alkalmazott és Környezeti Kémiai Tanszéken végezhessem doktori disszertációm megírásához szükséges munkámat.

Szeretnék köszönetet mondani Sápi András kollegámnak és barátomnak, hogy megosztotta velem sajátos világképét és hasznos tanácsival elöremozdította doktori munkámat.

Természetesen köszönöm a tanszék összes dolgozójának a rendkívüli légkört és a legkülönfélébb segítséget, amelyet munkám során nyújtottak.

Hálával tartozom Dr. Pulickel M. Ajayannak, Dr. Vajtai Róbertnek és Dr. Ashavani Kumarnak a Rice University-n nyújtott segítségéért és támogatásáért.

Köszönettel tartozom Dr. Kordás Krisztiánnak, hasznos észrevételeiért és a közös munka lehetőségéért, különösen az elektromos mérésekért.

Végül, de nem utolsó sorban szeretnék köszönetet mondani családomnak tanulmányaim során nyújtott támogatásukért, külön köszönöm Édesapám kutatásaimmal kapcsolatos tanácsait és megjegyzéseit. 


\section{ACKNOWLEDGEMENT}

First of all I wish to thank my family for their complete confidence and love during my graduate studies. Especially, I would like to thank to my father for his comments regarding my work.

I am heartily thankful to my supervisor Prof. Zoltán Kónya for guiding my career and for his useful suggestions regarding my work. Gratitude is also given to Prof. Ákos Kukovecz for the inspiring discussions, constructive comments and criticisms. Without their help and guidance, none of this work would have been possible.

I would like to thank to Prof. Imre Kiricsi, the late head of the Department of Applied and Environmental Chemistry, who gave me the opportunity to work in his group. He was a remarkable teacher who encouraged me during my research.

I am thankful for my colleague and friend András Sápi for sharing with me his unique way of seeing the world and for his useful advices.

I thank all of the staff of the Department of Applied and Environmental Chemistry of the University of Szeged.

I take this opportunity to truly thank, Prof. Pulickel M. Ajayan at Rice University, for his guidance, support and encouragement for my work and life. I am grateful for his hospitality which I enjoyed at Rice University. I express my gratitude to Prof. Róbert Vajtai and Dr. Ashavani Kumar at Rice University, for their technical assistance and discussions during my research. Many thanks to all group members in Prof. Ajayans' group for the wonderful time I had.

I express my gratitude to Prof. Krisztián Kordás at University of Oulu, for his constructive comments and for the collaborative work regarding the electrical measurements. 


\section{IRODALOMJEGYZÉK}

1. National Nanotechnology Initiative, http://www.nano.gov.

2. P. R. Feynman, Engineering and Science, 1960, 23:5, 22-36.

3. C. P. J. Poole and F. J. Owens, Wiley-Interscience, John Wiley \& Sons, INC., Hoboken, NJ, 2003, 1-7.

4. N. Taniguchi, Proceeding Intl. Conf. Prod. Eng. Tokyo, Part II, Japan Society of Precision Engineering, 1974.

5. $\quad$ K. E. Drexler, Doubleday, 1986.

6. G. Binnig and H. Rohrer, IBM Journal of Research and Development, 1986, 30: 4, 279-293.

7. H. W. Kroto, J. R. Heath, S. C. O'Brien, R. F. Curl and R. E. Smalley, Nature, 1985, 318, 162-163.

8. $\quad$ S. Iijima, Nature, $1991, \mathbf{3 5 4}, 56-58$.

9. K. S. Novoselov, A. K. Geim, S. V. Morozov, D. Jiang, Y. Zhang, S. V. Dubonos, I. V. Grigorieva and A. A. Firsov, Science, 2004, 306, 666-669.

10. A. Csanády, E. Kálmán and G. Konczos, MTA Kémiai Kutató Központ, ELTE Eötvös Kiadó, 2009, 13-18.

11. K. Ziemelis, Nature, 2000, 406, 1021-1021.

12. P. Buffat and J. P. Borel, Physical Review A, 1976, 13, 2287.

13. S. Link, C. Burda, M. B. Mohamed, B. Nikoobakht and M. A. El-Sayed, Physical Review B, 2000, 61, 6086.

14. $\quad$ Y. Wu and P. Yang, Applied Physics Letters, 2000, 77, 43-45.

15. J. Hu, T. W. Odom and C. M. Lieber, Accounts of Chemical Research, 1999, 32, 435445.

16. K. S. Shankar and A. K. Raychaudhuri, Materials Science and Engineering: C, 2005, 25, 738-751.

17. D. A. Wharam, T. J Thornton, R. Newbury, M. Pepper, H. Ahmed, J. E. F. Frost, D. G. Hasko, D. C. Peacock, D. A. Ritchie and G. A. C. Jones, Journal of Physics C: Solid State Physics, 1988, 21, L209.

18. Y. Cui, Q. Wei, H. Park and C. M. Lieber, Science, 2001, 293, 1289-1292.

19. D. H. Cobden, Nature, 2001, 409, 32-33.

20. X. Duan, Y. Huang, Y. Cui, J. Wang and C. M. Lieber, Nature, 2001, 409, 66-69.

21. Y. Huang, X. Duan, Y. Cui, L. J. Lauhon, K.-H. Kim and C. M. Lieber, Science, 2001, 294, 1313-1317.

22. R. F. Service, Science, 2001, 293, 782-785.

23. Z. Zhang, X. Sun, M. S. Dresselhaus, J. Y. Ying and J. Heremans, Physical Review B, 2000, 61, 4850.

24. Y. Xia, P. Yang, Y. Sun, Y. Wu, B. Mayers, B. Gates, Y. Yin, F. Kim and H. Yan, Advanced Materials, 2003, 15, 353-389.

25. C. Z. Li, H. X. He, A. Bogozi, J. S. Bunch and N. J. Tao, Applied Physics Letters, 2000, 76, 1333-1335.

26. F. Favier, E. C. Walter, M. P. Zach, T. Benter and R. M. Penner, Science, 2001, 293, 2227-2231.

27. M. Volmer and I. and Estermann, Zeitschrift für Physik A Hadrons and Nuclei 1921, 7, 13-17.

28. G. W. Sears, Acta Metallurgica, 1955, 3, 361-366. 
29. Y. Zhang, N. Wang, S. Gao, R. He, S. Miao, J. Liu, J. Zhu and X. Zhang, Chemistry of Materials, 2002, 14, 3564-3568.

30. D. M. Mattox, Handbook of Physical Vapor Deposition (PVD) Processing, Noyes Publications, Westwood NJ, USA, 1998.

31. R. S. Wagner and W. C. Ellis, Applied Physics Letters, 1964, 4, 89-90.

32. X. Duan and C. M. Lieber, Journal of the American Chemical Society, 1999, 122, 188-189.

33. Y. Wu and P. Yang, Chemistry of Materials, 2000, 12, 605-607.

34. M. Yazawa, M. Koguchi, A. Muto and K. Hiruma, Advanced Materials, 1993, 5, 577580.

35. Y. Wang, G. Meng, L. Zhang, C. Liang and J. Zhang, Chemistry of Materials, 2002, 14, 1773-1777.

36. Y. Wu and P. Yang, Journal of the American Chemical Society, 2001, 123, 31653166.

37. T. J. Trentler, K. M. Hickman, S. C. Goel, A. M. Viano, P. C. Gibbons and W. E. Buhro, Science, 1995, 270, 1791.

38. K. Byrappa and T. Adschiri, Progress in Crystal Growth and Characterization of Materials, 2007, 53, 117-166.

39. J. R. Heath and F. K. LeGoues, Chemical Physics Letters, 1993, 208, 263-268.

40. G. Wulff, Zeitschrift für Kristallographie, 1901, 34, 449.

41. J. A. Venables, Cambridge University Press, Cambridge, 2000, 4.

42. Z. L. Wang, The Journal of Physical Chemistry B, 2000, 104, 1153-1175.

43. T. S. Ahmadi, Z. L. Wang, T. C. Green, A. Henglein and M. A. El-Sayed, Science, 1996, 272, 1924-1925.

44. Y. Sun and Y. Xia, Science, 2002, 298, 2176-2179.

45. A. C. Curtis, D. G. Duff, P. P. Edwards, D. A. Jefferson, B. F. G. Johnson, A. I. Kirkland and A. S. Wallace, Angewandte Chemie International Edition in English, 1988, 27, 1530-1533.

46. J. S. Bradley, B. Tesche, W. Busser, M. Maase and M. T. Reetz, Journal of the American Chemical Society, 2000, 122, 4631-4636.

47. Y. Sun, B. Mayers, T. Herricks and Y. Xia, Nano Letters, 2003, 3, 955-960.

48. Y. Xiong and Y. Xia, Advanced Materials, 2007, 19, 3385-3391.

49. Y. Xiong, J. M. McLellan, Y. Yin and Y. Xia, Angewandte Chemie International Edition, 2007, 46, 790-794.

50. B. Lim, Y. Xiong and Y. Xia, Angewandte Chemie International Edition, 2007, 46, 9279-9282.

51. Y. Xia, Y. Xiong, B. Lim and S. E. Skrabalak, Angewandte Chemie International Edition, 2009, 48, 60-103.

52. Y. Sun, Y. Yin, B. T. Mayers, T. Herricks and Y. Xia, Chemistry of Materials, 2002, 14, 4736-4745.

53. Y. Sun, B. Gates, B. Mayers and Y. Xia, Nano Letters, 2002, 2, 165-168.

54. Y. Sun and Y. Xia, Advanced Materials, 2002, 14, 833-837.

55. F. Carmona, F. Barreau, P. Delhaes and R. Canet, Journal de Physique Lettres, 1980, 41, 531-533.

56. J. Stejny, J. Dlugosz and A. Keller, Journal of Materials Science, 1979, 14, 12911300.

57. K. W. Bagnall, The Chemistry of Selenium, Tellurium, Polonium, Elsevier, New York, 1966.

58. B. Gates, B. Mayers, B. Cattle and Y. Xia, Advanced Functional Materials, 2002, 12, 219-227. 
59. B. Gates, Y. Yin and Y. Xia, Journal of the American Chemical Society, 2000, 122, 12582-12583.

60. M. Mo, J. Zeng, X. Liu, W. Yu, S. Zhang and Y. Qian, Advanced Materials, 2002, 14, 1658-1662.

61. B. Mayers, B. Gates, Y. Yin and Y. Xia, Advanced Materials, 2001, 13, 1380-1384.

62. R. Helmut, S. Bernhard and V. Joachim, Angewandte Chemie International Edition in English, 1988, 27, 113-158.

63. R. Yang, C. Sui, J. Gong and L. Qu, Materials Letters, 2007, 61, 900-903.

64. A. Saedi and M. Ghorbani, Materials Chemistry and Physics, 2005, 91, 417-423.

65. G. E. Possin, Review of Scientific Instruments, 1970, 41, 772-774.

66. L. Sun, P. C. Searson and C. L. Chien, Applied Physics Letters, 1999, 74, 2803-2805.

67. C. M. Yang, H. S. Sheu and K. J. Chao, Advanced Functional Materials, 2002, 12, 143-148.

68. K. B. Lee, S. M. Lee and J. Cheon, Advanced Materials, 2001, 13, 517-520.

69. B. H. Hong, S. C. Bae, C.-W. Lee, S. Jeong and K. S. Kim, Science, 2001, 294, 348351.

70. F. Keller, M. S. Hunter and D. L. Robinson, Journal of The Electrochemical Society, 1953, 100, 411-419.

71. G. E. Thompson, R. C. Furneaux, G. C. Wood, J. A. Richardson and J. S. Goode, Nature, 1978, 272, 433-435.

72. H. Masuda and K. Fukuda, Science, 1995, 268, 1466-1468.

73. T. L. Wade and J. E. Wegrowe, The European Physical Journal - Applied Physics 2005, 29, 3-22.

74. J. C. Hulteen and C. R. Martin, Journal of Materials Chemistry, 1997, 7, 1075.

75. J.-G. Wang, M.-L. Tian, N. Kumar and T. E. Mallouk, Nano Letters, 2005, 5, 12471253.

76. C. R. Martin, Chemistry of Materials, 1996, 8, 1739-1746.

77. C. R. Martin, Science, 1994, 266, 1961-1966.

78. J. H. Sarah, P. Emma Kathryn, Q. Lidong and A. M. Chad, Angewandte Chemie International Edition, 2006, 45, 2672-2692.

79. M. E. T. Molares, V. Buschmann, D. Dobrev, R. Neumann, R. Scholz, I. U. Schuchert and J. Vetter, Advanced Materials, 2001, 13, 62-65.

80. J. C. v. B. Kjeld, F. Arianna and S. Seiji, Angewandte Chemie International Edition, 2003, 42, 980-999.

81. K. Nielsch, R. B. Wehrspohn, J. Barthel, J. Kirschner, U. Gosele, S. F. Fischer and H. Kronmuller, Applied Physics Letters, 2001, 79, 1360-1362.

82. C. K. Preston and M. Moskovits, The Journal of Physical Chemistry, 1993, 97, 84958503.

83. F. d. M. de Horne, L. Piraux and S. Michotte, Applied Physics Letters, 2005, 86, 152510-152513.

84. N. J. Gerein and J. A. Haber, The Journal of Physical Chemistry B, 2005, 109, 1737217385.

85. S. O. Obare, N. R. Jana and C. J. Murphy, Nano Letters, 2001, 1, 601-603.

86. K. S. Mayya, D. I. Gittins, A. M. Dibaj and F. Caruso, Nano Letters, 2001, 1, 727-730.

87. Y. Yin, Y. Lu, Y. Sun and Y. Xia, Nano Letters, 2002, 2, 427-430.

88. P. M. Ajayan, O. Stephan, P. Redlich and C. Colliex, Nature, 1995, 375, 564-567.

89. Y. Zhang and H. Dai, Applied Physics Letters, 2000, 77, 3015-3017.

90. G.-Y. Xiong, D. Z. Wang and Z. F. Ren, Carbon, 2006, 44, 969-973.

91. Y. Sun, B. T. Mayers and Y. Xia, Nano Letters, 2002, 2, 481-485. 
92. B. Gates, Y. Wu, Y. Yin, P. Yang and Y. Xia, Journal of the American Chemical Society, 2001, 123, 11500-11501.

93. B. Gates, B. Mayers, Y. Wu, Y. Sun, B. Cattle, P. Yang and Y. Xia, Advanced Functional Materials, 2002, 12, 679-686.

94. V. K. LaMer and R. H. Dinegar, Journal of the American Chemical Society, 1950, 72, 4847-4854.

95. M. A. Watzky and R. G. Finke, Journal of the American Chemical Society, 1997, 119, 10382-10400.

96. L. Colombi Ciacchi, W. Pompe and A. De Vita, Journal of the American Chemical Society, 2001, 123, 7371-7380.

97. J.-M. Zhang, F. Ma and K.-W. Xu, Applied Surface Science, 2004, 229, 34-42.

98. S. Iijima and T. Ichihashi, Physical Review Letters, 1986, 56, 616.

99. J. L. Elechiguerra, J. Reyes-Gasga and M. J. Yacaman, Journal of Materials Chemistry, 2006, 16, 3906-3919.

100. H. Hofmeister, S. A. Nepijko, D. N. Ievlev, W. Schulze and G. Ertl, Journal of Crystal Growth, 2002, 234, 773-781.

101. P. M. Ajayan and L. D. Marks, Physical Review Letters, 1988, 60, 585.

102. C. L. Cleveland and U. Landman, The Journal of Chemical Physics, 1991, 94, 73767396.

103. V. Germain, J. Li, D. Ingert, Z. L. Wang and M. P. Pileni, The Journal of Physical Chemistry B, 2003, 107, 8717-8720.

104. Y. Xiong, A. R. Siekkinen, J. Wang, Y. Yin, M. J. Kim and Y. Xia, Journal of Materials Chemistry, 2007, 17, 2600-2602.

105. B. Wiley, T. Herricks, Y. Sun and Y. Xia, Nano Letters, 2004, 4, 1733-1739.

106. B. J. Wiley, Y. Xiong, Z.-Y. Li, Y. Yin and Y. Xia, Nano Letters, 2006, 6, 765-768.

107. Y. Xiong, J. Chen, B. Wiley, Y. Xia, S. Aloni and Y. Yin, Journal of the American Chemical Society, 2005, 127, 7332-7333.

108. B. Wiley, Y. Sun and Y. Xia, Langmuir, 2005, 21, 8077-8080.

109. K. E. Korte, S. E. Skrabalak and Y. Xia, Journal of Materials Chemistry, 2008, 18, 437-441.

110. Y. Xiong, H. Cai, Y. Yin and Y. Xia, Chemical Physics Letters, 2007, 440, 273-278.

111. A. R. Tao, S. Habas and P. Yang, Small, 2008, 4, 310-325.

112. C. J. Murphy and N. R. Jana, Advanced Materials, 2002, 14, 80-82.

113. A. Azarian, A. Irajizad, A. Dolati and M. Ghorban, Journal of Physics: Condensed Matter, 2007, 19, 446007.

114. G. G. Jernigan and G. A. Somorjai, Journal of Catalysis, 1994, 147, 567-577.

115. Y. Zhang, W. Huang, S. E. Habas, J. N. Kuhn, M. E. Grass, Y. Yamada, P. Yang and G. A. Somorjai, The Journal of Physical Chemistry C, 2008, 112, 12092-12095.

116. S. S. Fu and G. A. Somorjai, The Journal of Physical Chemistry, 1992, 96, 4542-4549.

117. G. A. Somorjai, R. L. York, D. Butcher and J. Y. Park, Physical Chemistry Chemical Physics, 2007, 9, 3500-3513.

118. G. Somorjai, F. Tao and J. Park, Topics in Catalysis, 2008, 47, 1-14.

119. Z. Liu and Y. Bando, Advanced Materials, 2003, 15, 303-305.

120. H. Choi and S.-H. Park, Journal of the American Chemical Society, 2004, 126, 62486249.

121. M. E. T. Molares, E. M. Hohberger, C. Schaeflein, R. H. Blick, R. Neumann and C. Trautmann, Applied Physics Letters, 2003, 82, 2139-2141.

122. Z. Liu, Y. Yang, J. Liang, Z. Hu, S. Li, S. Peng and Y. Qian, The Journal of Physical Chemistry B, 2003, 107, 12658-12661. 
123. M. Y. Yen, C. W. Chiu, C. H. Hsia, F. R. Chen, J. J. Kai, C. Y. Lee and H. T. Chiu, Advanced Materials, 2003, 15, 235-237.

124. A. Filankembo and M. P. Pileni, The Journal of Physical Chemistry B, 2000, 104, 5865-5868.

125. M.-P. Pileni, Nature Materials, 2003, 2, 145-150.

126. D. Dobrev, J. Vetter, N. Angert and R. Neumann, Applied Physics A: Materials Science \& Processing, 1999, 69, 233-237.

127. T. Gao, G. W. Meng, J. Zhang, Y. W. Wang, C. H. Liang, J. C. Fan and L. D. Zhang, Applied Physics A: Materials Science \& Processing, 2001, 73, 251-254.

128. M. Tian, J. Wang, J. Kurtz, T. E. Mallouk and M. H. W. Chan, Nano Letters, 2003, 3, 919-923.

129. J.-L. Duan, J. Liu, H.-J. Yao, D. Mo, M.-D. Hou, Y.-M. Sun, Y.-F. Chen and L. Zhang, Materials Science and Engineering: B, 2008, 147, 57-62.

130. M. E. Toimil Molares, J. Brötz, V. Buschmann, D. Dobrev, R. Neumann, R. Scholz, I. U. Schuchert, C. Trautmann and J. Vetter, Nuclear Instruments and Methods in Physics Research Section B: Beam Interactions with Materials and Atoms, 2001, 185, 192-197.

131. S. Fletcher, Journal of Crystal Growth, 1983, 62, 505-512.

132. A. Filankembo, S. Giorgio, I. Lisiecki and M. P. Pileni, The Journal of Physical Chemistry B, 2003, 107, 7492-7500.

133. M. Cao, C. Hu, Y. Wang, Y. Guo, C. Guo and E. Wang, Chemical Communications, 2003, 15, 1884-1885.

134. A. A. Setlur, J. M. Lauerhaas, J. Y. Dai and R. P. H. Chang, Applied Physics Letters, 1996, 69, 345-347.

135. X. Kai, T. Jing, P. Zhengwei, A. P. Alex, N. I. Ilia, J. P. Stephen and B. G. David Angewandte Chemie International Edition, 2007, 46, 2650-2654.

136. Z. Liu, Y. Gao and Y. Bando, Applied Physics Letters, 2002, 81, 4844-4846.

137. W. Wang, N. Li, X. Li, W. Geng and S. Qiu, Materials Research Bulletin, 2006, 41, 1417-1423.

138. Y. Chang, M. L. Lye and H. C. Zeng, Langmuir, 2005, 21, 3746-3748.

139. X. Zhang, D. Zhang, X. Ni and H. Zheng, Solid State Communications, 2006, 139, 412-414.

140. X. Zhang, D. Zhang, X. Ni and H. Zheng, Chemistry Letters, 2006, 35, 1142-1143.

141. W. Wang, G. Li and Z. Zhang, Journal of Crystal Growth, 2007, 299, 158-164.

142. S. Yu, Hong Li, L. Chen and X. Huang, Science and Technology of Advanced Materials, 2005, 6, 761.

143. B. Deng, A.-W. Xu, G.-Y. Chen, R.-Q. Song and L. Chen, The Journal of Physical Chemistry B, 2006, 110, 11711-11716.

144. Y.-S. Cho and Y.-D. Huh, Materials Letters, 2009, 63, 227-229.

145. H. Cao, L. Wang, Y. Qiu and L. Zhang, Nanotechnology, 2006, 17, 1736.

146. X. Yujie, W. Benjamin, C. Jingyi, L. Zhi-Yuan, Y. Yadong and X. Younan, Angewandte Chemie International Edition, 2005, 44, 7913-7917.

147. Y. Ding and J. Erlebacher, Journal of the American Chemical Society, 2003, 125, 7772-7773.

148. V. F. Puntes, K. M. Krishnan and A. P. Alivisatos, Science, 2001, 291, 2115-2117.

149. L. A. Gugliotti, D. L. Feldheim and B. E. Eaton, Science, 2004, 304, 850-852.

150. X. Teng and H. Yang, Nano Letters, 2005, 5, 885-891.

151. Y. Sun and Y. Xia, Advanced Materials, 2004, 16, 264-268.

152. Y. Sun and Y. Xia, Journal of the American Chemical Society, 2004, 126, 3892-3901. 
153. Y. Sun, B. Wiley, Z.-Y. Li and Y. Xia, Journal of the American Chemical Society, 2004, 126, 9399-9406.

154. M. Hu, J. Chen, M. Marquez, Y. Xia and G. V. Hartland, The Journal of Physical Chemistry C, 2007, 111, 12558-12565.

155. X. Lu, L. Au, J. McLellan, Z.-Y. Li, M. Marquez and Y. Xia, Nano Letters, 2007, 7, 1764-1769.

156. L. Au, Y. Chen, F. Zhou, P. Camargo, B. Lim, Z.-Y. Li, D. Ginger and Y. Xia, Nano Research, 2008, 1, 441-449.

157. X. Gu, L. Xu, F. Tian and Y. Ding, Nano Research, 2009, 2, 386-393.

158. L. Yingpu Bi and Gongxuan, Nanotechnology, 2008, 19, 275306.

159. C. Zhongwei, W. Mahesh, L. Wenzhen and Y. Yushan, Angewandte Chemie International Edition, 2007, 46, 4060-4063.

160. Y. Bi and G. Lu, Chemistry of Materials, 2008, 20, 1224-1226.

161. G. W. Slawinski and F. P. Zamborini, Langmuir, 2007, 23, 10357-10365.

162. J. Chen, B. Wiley, J. McLellan, Y. Xiong, Z.-Y. Li and Y. Xia, Nano Letters, 2005, 5, 2058-2062.

163. S. H. Im, Y. T. Lee, B. Wiley and Y. Xia, Angewandte Chemie International Edition, 2005, 44, 2154-2157.

164. A. R. Siekkinen, J. M. McLellan, J. Chen and Y. Xia, Chemical Physics Letters, 2006, 432, 491-496.

165. J. H. Song, Y. Wu, B. Messer, H. Kind and P. Yang, Journal of the American Chemical Society, 2001, 123, 10397-10398.

166. Y. Sun, B. Mayers and Y. Xia, Advanced Materials, 2003, 15, 641-646.

167. X. Lu, J. Chen, S. E. Skrabalak and Y. Xia, Proceedings of the I MECH E Part N Journal of Nanoengineering and Nanosystems, 2008, 221, 1-16.

168. S. K. Wonnell, J. M. Delaye, M. Bibole and Y. Limoge, Journal of Applied Physics, 1992, 72, 5195-5205.

169. J. Erlebacher, M. J. Aziz, A. Karma, N. Dimitrov and K. Sieradzki, Nature, 2001, 410, 450-453.

170. T. Shahrabi, R. C. Newman and K. Sieradzki, Journal of The Electrochemical Society, 1993, 140, 348-352.

171. A. R. Roosen and W. C. Carter, Physica A: Statistical and Theoretical Physics, 1998, 261, 232-247.

172. L. Han-Pu, Z. Hui-Min, H. Jin-Song, G. Yu-Guo, W. Li-Jun and B. Chun-Li, Angewandte Chemie International Edition, 2004, 43, 1540-1543.

173. I. Pastoriza-Santos and L. M. Liz-Marzan, Langmuir, 2002, 18, 2888-2894.

174. J. Zhang, K. Sasaki, E. Sutter and R. R. Adzic, Science, 2007, 315, 220-222.

175. P. J. Ferreira, G. J. la O, Y. Shao-Horn, D. Morgan, R. Makharia, S. Kocha and H. A. Gasteiger, Journal of The Electrochemical Society, 2005, 152, A2256-A2271.

176. J. Xie, D. L. Wood Iii, D. M. Wayne, T. A. Zawodzinski, P. Atanassov and R. L. Borup, Journal of The Electrochemical Society, 2005, 152, A104-A113.

177. X. Lu, M. McKiernan, Z. L. Peng, H. Eric P.; Yang and Y. Xia, Science of Advanced Materials, 2010, 2, 413-420.

178. G. A. Somorjai, Science, 1985, 227, 902-908.

179. I. Horiuti and M. Polanyi, Transactions of the Faraday Society, 1934, 30.

180. P. S. Cremer, X. Su, Y. R. Shen and G. A. Somorjai, Journal of the American Chemical Society, 1996, 118, 2942-2949.

181. A. Cassuto, J. Kiss and J. M. White, Surface Science, 1991, 255, 289-294.

182. P. S. Cremer and G. A. Somorjai, Journal of the Chemical Society, Faraday Transactions, 1995, 91, 3671-3677. 
183. P. Cremer, C. Stanners, J. W. Niemantsverdriet, Y. R. Shen and G. Somorjai, Surface Science, 1995, 328, 111-118.

184. T. A. Land, T. Michely, R. J. Behm, J. C. Hemminger and G. Comsa, The Journal of Chemical Physics, 1992, 97, 6774-6783.

185. G. A. Somorjai, A. M. Contreras, M. Montano and R. M. Rioux, Proceedings of the National Academy of Sciences, 2006, 103, 10577-10583.

186. S. H. Tolbert and A. P. Alivisatos, Annual Review of Physical Chemistry, 1995, 46, 595-626.

187. C.-C. Chen, A. B. Herhold, C. S. Johnson and A. P. Alivisatos, Science, 1997, 276, 398-401.

188. G. Meng, A. Cao, J.-Y. Cheng, A. Vijayaraghavan, Y. J. Jung, M. Shima and P. M. Ajayan, Journal of Applied Physics, 2005, 97, 064303-064305.

189. W. S. Rasband, U. S. National Institutional of Health, Bethesda, Maryland, USA (http://imagej.nih.gov/ij/), 1997.

190. X. Teng, Q. Wang, P. Liu, W. Han, A. I. Frenkel, Wen, N. Marinkovic, J. C. Hanson and J. A. Rodriguez, Journal of the American Chemical Society, 2007, 130, 10931101.

191. X. Lu, H.-Y. Tuan, J. Chen, Z.-Y. Li, B. A. Korgel and Y. Xia, Journal of the American Chemical Society, 2007, 129, 1733-1742.

192. L. Au, X. Lu and Y. Xia, Advanced Materials, 2008, 20, 2517-2522.

193. A. Kumar, S. Mandal, R. Pasricha, A. B. Mandale and M. Sastry, Langmuir, 2003, 19, 6277-6282.

194. V. Bansal, H. Jani, J. Du Plessis, P. J. Coloe and S. K. Bhargava, Advanced Materials, 2008, 20, 717-723.

195. B. Viswanath, S. Patra, N. Munichandraiah and N. Ravishankar, Langmuir, 2009, 25, 3115-3121.

196. W. Stöber, A. Fink and E. Bohn, Journal of Colloid and Interface Science, 1968, 26, 62-69.

197. Y. T. Lim, O. O. Park and H.-T. Jung, Journal of Colloid and Interface Science, 2003, 263, 449-453.

198. F. C. Henn, A. L. Diaz, M. E. Bussell, M. B. Hugenschmidt, M. E. Domagala and C. T. Campbell, The Journal of Physical Chemistry, 1992, 96, 5965-5974.

199. L. Piccolo, C. Becker and C. R. Henry, Applied Surface Science, 2000, 164, 156-162.

200. S. Morales-Torres, A. F. Pérez-Cadenas, F. Kapteijn, F. Carrasco-Marín, F. J. Maldonado-Hódar and J. A. Moulijn, Applied Catalysis B: Environmental, 2009, 89, 411-419.

201. E. W. Hansen and M. Neurock, Journal of Catalysis, 2000, 196, 241-252.

202. H. Molero, D. Stacchiola and W. T. Tysoe, Catalysis Letters, 2005, 101, 145-149.

203. O. Beeck, Reviews of Modern Physics, 1945, 17, 61.

204. Y. Takasu, T. Sakuma and Y. Matsuda, Chemistry Letters, 1985, 14, 1179-1182.

205. A. N. R. Bos, E. S. Botsma, F. Foeth, H. W. J. Sleyster and K. R. Westerterp, Chemical Engineering and Processing: Process Intensification, 1993, 32, 53-63.

206. M. K. Al-Noori and J. M. Saleh, Journal of the Chemical Society, Faraday Transactions 1: Physical Chemistry in Condensed Phases, 1973, 69, 2140-2146.

207. C. Z. L. Chen, J. Wu, H. Cheng, Frontiers of Physics China, 2009, 4, 356.

208. P. E. C. Franken and V. Ponec, Surface Science, 1975, 53, 341-350.

209. M. Neurock, V. Pallassana and R. A. van Santen, Journal of the American Chemical Society, 2000, 122, 1150-1153.

210. J. C. Schlatter and M. Boudart, Journal of Catalysis, 1972, 24, 482-492.

211. T. A. Dorling, M. J. Eastlake and R. L. Moss, Journal of Catalysis, 1969, 14, 23-33. 
212. J. H. Sinfelt, The Journal of Physical Chemistry, 1964, 68, 856-860.

213. V. B. Kazanskii and V. P. Strunin, Kinet. Katal., 1960, 1, 553.

214. M. Mohl, A. Kumar, A. L. M. Reddy, A. Kukovecz, Z. Konya, I. Kiricsi, R. Vajtai and P. M. Ajayan, The Journal of Physical Chemistry C, 2009, 114, 389-393.

215. A. Goyal, M. Mohl, A. Kumar, R. Puskas, A. Kukovecz, Z. Konya, I. Kiricsi and P. M. Ajayan, Composites Science and Technology, 2011, 71, 129-133.

216. C. N. Satterfield, Heterogenous Catalysis in Practice (McGraw-Hill chemical engineering series) McGraw-Hill Inc., USA 1980.

217. D. B. Williams and C. B. Carter, Transmission Electron Microscopy: A Textbook for Materials Science, Springer Science+Business Media, LLC, 233 Spring Street, New York, NY 10013, USA, 2009.

218. L. Yadong, L. Xiaolin, D. Zhao-Xiang, Z. Beichuan, F. Shoushan, W. Junwei and S. Xiaoming, Angewandte Chemie International Edition, 2002, 41, 333-335.

219. M. Mohl, P. Pusztai, A. Kukovecz, Z. Konya, J. Kukkola, K. Kordas, R. Vajtai and P. M. Ajayan, Langmuir, 2010, 26, 16496-16502.

220. R. Singh, R. Kumar and S. K. Chakarvarti, Physica E: Low-dimensional Systems and Nanostructures, 2008, 40, 591-593.

221. Z. Chen, M. Waje, W. Li and Y. Yan, Angewandte Chemie International Edition, 2007, 46, 4060-4063.

222. R. C. Newman and K. Sieradzki, Science, 1994, 263, 1708-1709.

223. Y. Yin, R. M. Rioux, C. K. Erdonmez, S. Hughes, G. A. Somorjai and A. P. Alivisatos, Science, 2004, 304, 711-714.

224. S. Zhou, B. Varughese, B. Eichhorn, G. Jackson and K. McIlwrath, Angewandte Chemie International Edition, 2005, 44, 4539-4543.

225. O. Ghodbane, L. Roué and D. Bélanger, Chemistry of Materials, 2008, 20, 3495-3504.

226. M.-H. Shao, K. Sasaki and R. R. Adzic, Journal of the American Chemical Society, 2006, 128, 3526-3527.

227. C. Xu, Y. Zhang, L. Wang, L. Xu, X. Bian, H. Ma and Y. Ding, Chemistry of Materials, 2009, 21, 3110-3116.

228. A. Sarkar, A. V. Murugan and A. Manthiram, The Journal of Physical Chemistry C, 2008, 112, 12037-12043.

229. X. Wang, N. Kariuki, J. T. Vaughey, J. Goodpaster, R. Kumar and D. J. Myers, Journal of The Electrochemical Society, 2008, 155, B602-B609.

230. C. Xu, L. Wang, R. Wang, K. Wang, Y. Zhang, F. Tian and Y. Ding, Advanced Materials, 2009, 21, 2165-2169.

231. A. C. A. de Vooys, R. A. van Santen and J. A. R. van Veen, Journal of Molecular Catalysis A: Chemical, 2000, 154, 203-215.

232. U. Matatov-Meytal and M. Sheintuch, Catalysis Today, 2005, 102-103, 121-127. 